Aus dem Department für Nutztierwissenschaften

\title{
Indicator-based flock management in broilers and turkeys - mortality, foot pad health and environmental factors
}

\author{
Dissertation \\ Zur Erlangung des Doktorgrades \\ der Fakultät für Agrarwissenschaften \\ der Georg-August-Universität Göttingen
}

vorgelegt von
Kathrin Toppel
geboren in

Wernigerode, Sachsen-Anhalt

Göttingen, Dezember 2020 


\section{7}

1. Referent: Prof. Dr. Dr. Matthias Gauly

2. Korreferent: Prof. Dr. Robby Andersson

Tag der mündlichen Prüfung: 13. Juli 2018 

Meiner Familie

To Rose

To José Daniel 


\section{Content}

Zusammenfassung

III

Summary IX

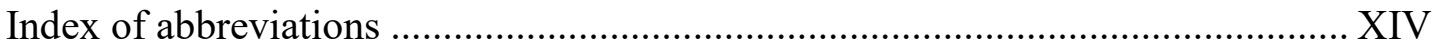

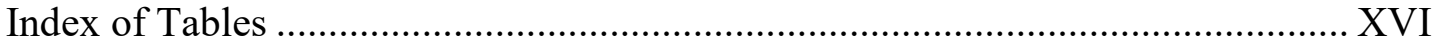

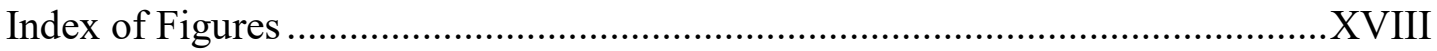

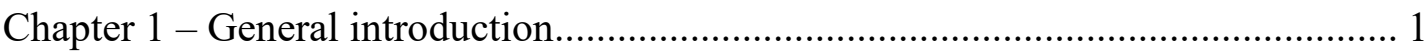

Development of German Poultry Husbandry ....................................................... 1

Welfare Issues in Poultry Husbandry ................................................................. 4

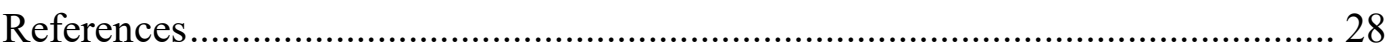

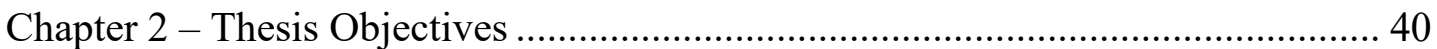

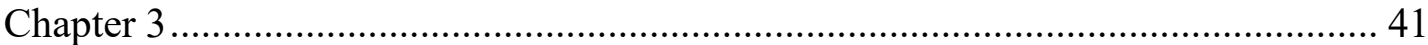

Development of mortality and foot pad health in turkey flocks and its implication for

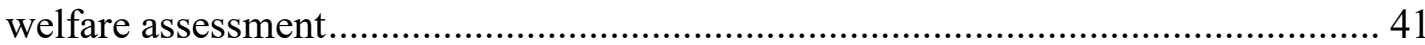

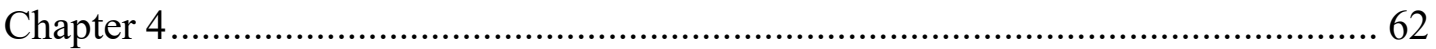

Foot pad health as part of on-farm-monitoring in turkey flocks............................. 62

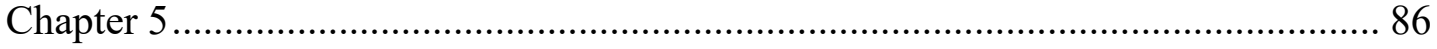

Effect of pH-lowering Litter Amendment on Animal-based welfare Indicators and Litter Quality in a European commercial Broiler Husbandry .................................. 86

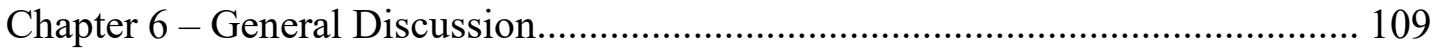

Use of the indicator 'mortality' as part of on-farm-monitoring in poultry flocks 110

Use of the indicator 'foot pad health' as part of on-farm-monitoring in poultry

flocks

Approaches for an objective foot pad assessment method to improve animal welfare 
Conclusions of the thesis/ Recommendations for an indicator-based management:

References... 129

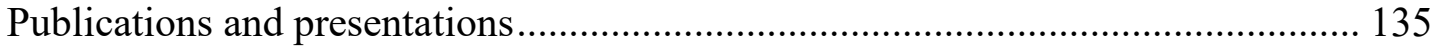

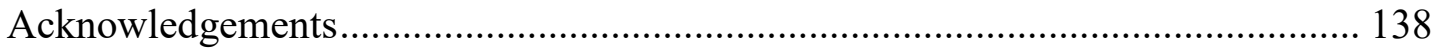




\section{Zusammenfassung}

Die im deutschen Tierschutzgesetz §11, Abs.8 seit 2014 geforderte betriebliche Eigenkontrolle verpflichtet alle Tierhalter und tierbetreuenden Personen zur Erhebung und Bewertung von Tierschutzindikatoren im laufenden Bestand. Die Nutzung von Tierschutzindikatoren soll dazu beitragen, die graduellen tierschutzrelevanten Situationen zu erfassen, die dem Tierwohl zuordenbar sind. Sie ergänzen eine Bewertung von Haltungssystemen anhand ressourcenbasierter und managementbezogener Merkmale wie beispielsweise dem Platzangebot pro Tier. Durch die Anwendung von Tierschutzindikatoren soll sichergestellt werden, dass die für die Tierhaltung verantwortlichen Personen eine Tierhaltung gewährleisten, die sich an den Bedürfnissen der Tiere orientiert. In der vorliegenden Arbeit schließt der Begriff animal welfare den Terminus animal protection zum besseren Verständnis mit ein (vgl. §11, 8 Lorz and Metzger 2019).

Als geeignete Tierschutzindikatoren in der Mastgeflügelhaltung werden u.a. die Entwicklung des Lebendgewichts, die Mortalität oder auch die Fußballengesundheit diskutiert. Durch die regelmäßige Bewertung der erfassten Daten wird Herdenmanagern ein Soll-Ist Abgleich ermöglicht. Ein Indikator-basiertes Bestandscontrolling stützt sich im Vergleich zu Kontrollinstrumenten nicht auf die Anwendung von Grenzwerten mit gegebenenfalls einer gekoppelten Sanktionierung bei Über- oder Unterschreitung, sondern auf den regelnden Soll-Ist Abgleich durch die bestandsbetreuende Person. Dies erfordert Kenntnisse über Risikobereiche sowie Schwellenwerte und Zielgrößen. Die Steuerung eines Bestands mit der Implementierung von Maßnahmen, wenn erforderlich, soll messbar zu einer kontinuierlichen Verbesserung von Haltungsbedingungen für Nutztiere beitragen und die Eigenverantwortlichkeit der Tierhalter und -betreuer stärken. Können bereits im Betrieb vorliegende Daten genutzt werden, könnte dies die Akzeptanz eines solchen Indikator-basierten Managementsystems auf betrieblicher Ebene noch erhöhen und so den Tierschutz und das Tierwohl auf einzelbetrieblicher Ebene steigern.

In der vorliegenden Arbeit zum Mastgeflügel sollten die für das Bestandscontrolling in Putenbeständen erforderlichen Schwellenwerte und Erwartungswerte für die Indikatoren Mortalität und Fußballengesundheit erarbeitet werden. Anschließend 
wurden Erhebungsmethoden zur Fußballengesundheit als objektive, valide und reliabele Messgröße im Sinne eines Indikators im Bestandscontrolling bewertet. Im dritten Schritt wurden mögliche Managementmaßnahmen auf Ihre Eignung zur Förderung der Fußballengesundheit im Masthühnerbestand erprobt und evaluiert.

In der ersten Untersuchung (Chapter 3) wurden die Indikatoren Mortalität und Fußballengesundheit auf 13 putenhaltenden Betrieben im nord-westdeutschen Raum über einen Zeitraum von zwei aufeinanderfolgenden Durchgängen erhoben und bewertet. Die Praxisstudie berücksichtigte beide Geschlechter sowie saisonale Einflüsse (Winterdurchgang Oktober bis März, Sommerdurchgang April bis September). Ein Bestand konnte sich auf mehrere Herden verteilen, eine Herde umfasste eine bauliche Einheit. Es wurde in jeder Herde anhand einer zufällig gewählten Stichprobe von 60 Tieren in vierwöchentlichem Abstand nach dem 5stufigen Score nach Hocking et al. (2008) die Fußballengesundheit erhoben und bewertet. Insgesamt flossen 11.400 Einzeltierdaten, d.h. 22.800 Daten zur Fußballenbewertung, in die Studie ein. Diese Datengrundlage wurde auch für die 2. Studie, Chapter 4, genutzt. Bestandsdaten wie Mortalität sowie Daten zum Einstreumanagement wurden regelmäßig erfasst.

Aus den Daten der Aufzuchtverluste stellte sich im Ergebnis heraus, dass die Höhe der Tierverluste zum Ende der 1. Lebenswoche (LWo) positiv mit der Gesamtmortalität der Aufzucht korreliert (Spearman $r=0,677 ; \mathrm{p}<0,01$ ). Für die Bestandsbetreuung gibt die 7-Tage Mortalität einen Hinweis darauf, ob das Management im weiteren Fortlauf der Herdenbetreuung intensiviert werden muss. Das heißt, auch für den Mäster, der die Tiere aus der Aufzucht übernimmt, ist diese Information von Bedeutung. Ein saisonaler Einfluss ließ sich ermitteln, im Sommerdurchgang war die Gesamtmortalität bei den Hahnenherden um 0,5 \%-Punkte im Vergleich zum Winter erhöht. Zudem wurde insgesamt der Bereich 14./15. LWo als Risikozeitraum für die Mortalität herausgestellt, für die Sommerdurchgänge besteht jedoch ein zusätzliches Risikofenster um die 12./13. LWo sowie 20./21. LWo. Die Auswertung und Darstellung von Quartilen zeigt nicht nur Schwellenwerte und Risikobereiche für ein erhöhtes Mortalitätsrisiko auf, sondern auch das Potenzial von Betrieben über die Mastperiode, das für die Zielwertformulierung des Indikators Mortalität von Bedeutung ist. 
Für den Indikator Fußballengesundheit wurden die ersten 8 LWo als Risikobereich für Pododermatitis identifiziert, unabhängig von Geschlecht und Saisonalität. Zum Schlachtzeitpunkt wurden keine Unterschiede zwischen den Geschlechtern festgestellt (Median Hennen 2,32 vs. Hahn 2,35 bei Score 0-unverändert bis Score 4-mehr als 50\% nekrotisierter Sohlenballen). Die Ergebnisse zum Einstreumanagement in der Hahnenmast zeigten, dass ein ereignisbezogenes Einstreuen mit weniger Einstreuterminen (2-3 vs. 4-6 mal/ Woche), einer insgesamt geringeren Einstreumenge (11,2-14,2 vs. 17,5-22,6 kg Stroh/ $\left.\mathrm{m}^{2}\right)$ und verbesserter Fußballengesundheit (FPD Score Median 2,2 vs. 2,7) einhergeht. Die Einstreumenge wurde als signifikanter Effekt ( $p=0,012$ ) auf die Fußballengesundheit herausgearbeitet.

In der sich anschließenden Studie (Chapter 4) wurde die Methodik der Erhebung und Bewertung der Fußballengesundheit, um diese Messgröße im Sinne eines Tierschutzindikators nutzen zu können, untersucht. Die Erhebung der Veränderungen am Sohlenballen, wie bereits aus der 1. Studie beschrieben, erfolgte je Einzeltier an beiden Füßen, die Berechnung des Spearman' Rangkorrelationskoeffizienten für den Score rechter und linker Sohlenballen sollte Auskunft über die Methode zur Bewertung im Bestand geben. Auf Basis der Einzeltierdaten ergaben sich im Vergleich der Scores zwischen rechtem und linken Sohlenballen Korrelationen zwischen r=0,355 und r=1,000 (Spearman Rho). Für die frühzeitige Erkennung der Notwendigkeit von Maßnahmen empfiehlt sich daher die Bonitur beider Füße eines Tieres und der am stärksten veränderte Sohlenballen wird in die Bewertung übernommen.

Weiterhin wurden Berechnungen zum erforderlichen Stichprobenumfang für verschiedene Konfidenzintervalle $(\alpha=0,01,0,05,0,1)$ in Abhängigkeit von der Herdengröße vorgenommen, die auf einer erwarteten Prävalenz von Fußballenveränderungen beruhen. Die Berechnung der Stichprobengröße ergab beispielhaft für die manuelle Fußballenbewertung in einer Herde mit 4000 Tieren und einem erwarteten Auftreten von Sohlenballenveränderungen an 40 \% der Herde die Erhebung von 77 Tieren bei einer Irrtumswahrscheinlichkeit von $10 \%$. Für die Bestandsbonitur leitet sich aus den Ergebnissen ab, dass die Stichprobe durchaus variieren und in Abhängigkeit von der Herdengröße und auch der zu erwartenden Prävalenz von Sohlenballenveränderungen erfolgen sollte. Als Anhaltspunkt liefern 
die erhobenen Daten aus der ersten Studie (Figure 4) Ergebnisse zum Auftreten von Fußballenveränderungen in den ersten 8 LWo.

Zudem bildeten 30 Fußballen geschlachteter Tiere die Grundlage eines Abgleichs von makroskopischer Bewertung (nach Hocking et al. 2008) und histologischer Untersuchung. Dafür wurden Gewebeproben von Metatarsalballen entnommen, welche vorab über 24 Stunden in einer 10\% Formalinlösung fixiert waren. Nach einer Hämatoxilin-Eosin-Übersichtsfärbung wurden Epidermis und Dermis lichtmikroskopisch untersucht. Um die subjektive d.h. manuell bewertete Größe der Veränderungen am Sohlenballen in Relation zur Fläche des Metatarsalballens objektiv $\mathrm{zu}$ bewerten, wurde auf der Grundlage von 20 Sohlenballen mit Hilfe des Bildprogramms ImageJ 1.51k der Umfang des Metatarsalballens sowie veränderte Bereiche gemessen. Die Ergebnisse wurden der Bewertung des 5er-Scores nach Hocking et al. (2008) zugeordnet und interpretiert. Durch den Abgleich zwischen histo-pathologischen Veränderungen mit der makroskopischen Bewertung konnten moderate Ulzerationen dem makroskopischen Score 1 und Score 2 (nach Hocking et al. 2008) zugeordnet werden. Für die Bestandsbewertung ist folglich ein Scoringsystem erforderlich, das bereits erste Veränderungen an der Oberfläche des Sohlenballens separat von Score 0 - keine Veränderungen - ausweist. So können frühzeitig mögliche Ursachen zugeordnet und im Bestand Maßnahmen ergriffen werden. Ebenso ist das separate Kategorisieren von Narbengewebe ein wichtiger Hinweis für Abheilungsprozesse und den Erfolg von Maßnahmen im laufenden Bestand. Der am Beispiel des Scoringsystems nach Hocking et al. (2008) vorgenommene Vergleich der Bonituren von Sohlenballenveränderungen mittels manueller Bonitur und einem Bildprogramm, machte die s.g. optische Illusion deutlich und führte zur schlechteren Einstufung durch die manuelle Bonitur. Zudem zeigte sich, dass eine einheitliche Definition zur Abgrenzung des Metatarsalballens als Bezugsgröße für den Anteil veränderter Fläche notwendig ist. Das in den Schlachthöfen etablierte Scoringsystem nach Hocking et al. (2008) ist für die Bewertung zum Schlachtzeitpunkt (p.m.) erarbeitet worden und bildet die genannten Anforderungen für die Bewertung im Bestand, und p.m. vor dem Hintergrund der entwickelten Kamerasysteme, nicht oder nur unzureichend ab. 
Abschließend wurde im Rahmen der Dissertation eine in den USA bereits bewährte Einstreumaßnahme im Bestand auf ihre Eignung zur Verbesserung der Fußballengesundheit unter den hiesigen Vorgaben zur Masthühnerhaltung geprüft (Chapter 5). Hierzu wurde in einer Praxisstudie der Effekt einer Applikation eines pHWert reduzierenden Einstreupflegemittels (Bisulfat-Komplex; SBS) auf die Fußballengesundheit sowie Sprunggelenksveränderungen und die Einstreuparameter Trockensubstanz (TS), pH-Wert und Ammoniumstickstoff $\left(\mathrm{NH}_{4}-\mathrm{N}\right)$ untersucht. Je Durchgang wurden in zwei baugleichen Ställen parallel eine Versuchs- und eine Kontrollgruppe, nachfolgend als TRT bzw. Con bezeichnet, gehalten und zwei Applikationsmengen mit jeweils einer Wiederholung geprüft. SBS wurde innerhalb 24 $\mathrm{h}$ vor Aufstallung der Tiere oberflächlich auf die Grundeinstreu, $700 \mathrm{~g} / \mathrm{m}^{2}$ Strohgranulat, in einer Menge von $250 \mathrm{~g} / \mathrm{m}^{2}$ (TRT 1) oder $150 \mathrm{~g} / \mathrm{m}^{2}$ (TRT 2) in der jeweiligen Versuchsgruppe (SBS) ausgebracht, die Kontrollgruppe (Con) wurde ohne Einstreupflegemittel gehalten. Die wöchentlich erhobenen tierbezogenen Merkmale Lebendgewicht sowie Fußballen- und Sprunggelenksveränderungen wurden an einer zufällig gewählten Stichprobe von 60 Tieren je Gruppe und Termin in Anlehnung an das Bewertungssystem nach Welfare Quality (Score 0-4) erhoben und bewertet. Einstreuproben wurden in den Bereichen Tränke, Futterlinie und freie Fläche wöchentlich entnommen und ausgewertet. Die Ergebnisse zeigten keinen Effekt auf die Gewichtsentwicklung durch die Applikation des Bisulfat Komplexes ( $p=0,687$ bzw. $p=0,890)$. Die Verlustraten waren höher in den Versuchs- gegenüber den Kontrollgruppen (TRT 1 2,79 vs. Con 2,03\%; TRT 2 2,88 vs. Con 2,27\%). Das Auftreten von Fußballenveränderungen war durch die Bisulfat-Komplex Applikation signifikant verringert (p.m. $p=0,011$ und $p=0,000$ ), wobei die höhere Einsatzmenge $\left(250 \mathrm{~g} / \mathrm{m}^{2}\right)$ die besten Ergebnisse aufwies. Ein Unterschied zwischen den Gruppen bezüglich der Fersenhöckergesundheit konnte nicht nachgewiesen werden (p.m. $\mathrm{p}=0,200$ und $\mathrm{p}=0,115$ ), jedoch beeinflusste der TS-Gehalt der Einstreu diesen Parameter signifikant ( $\mathrm{p}=0,037)$. Die anfängliche Reduktion des Einstreu $\mathrm{pH}-$ Wertes auf ca. pH 1,7 und 2,0 gegenüber 6,5 bzw. 6,7 in den Kontrollgruppen zeigten somit eine mögliche Managementmaßnahme für den Betrieb zur Prävention bzw. Verringerung von Fußballenveränderungen unter kommerziellen Bedingungen auf. 
Die Ergebnisse der Arbeit zeigen sowohl den jahreszeitlichen Einfluss als auch das Erfordernis der Berücksichtigung des Alters der Tiere, um Bestandsdaten zu bewerten. Um das Tierwohl in Betrieben sowie das Risiko einer Auffälligkeit zu bewerten, müssen folglich mehrere Durchgänge einbezogen werden. Zudem unterstützt ein indikator-basiertes Bestandsmanagement bei der Früherkennung von Fehlentwicklungen, hierfür wurden Kenntnisse um Risikobereiche und Schwellenwerte sowie Ziel -und Erwartungsbereiche gewonnen. Die Ergebnisse können als Grundlage für die Anwendung eines Controllings in Putenbeständen unter Nutzung des Indikators Fußballengesundheit für die Pflege, Unterbringung, Ernährung und Bewegung (vgl. $\S 2$ TierSchG) als nutzbare Informationsbasis für den Status quo der Herde dienen. Dass Tierschutzindikatoren wie Mortalität und Fußballenveränderungen bereits ab der Aufzucht erhoben und bewertet werden sollten, wird, unter Weitergabe der bewerteten Informationen auch an die Maststufe, sowie umgekehrt von der Maststufe einschließlich Schlachtung an die Aufzucht, zu einer kontinuierlichen Verbesserung in der Nutzgeflügelhaltung führen. Die Voraussetzung bilden einheitliche objektive Messverfahren sowie Bewertungssysteme; dafür liefert diese Arbeit für die Indikatoren Mortalität und Fußballenveränderungen neben Anforderungen in der Anwendung auch Lösungsansätze. 


\section{Summary}

For a long time, animal husbandry systems were evaluated with resource-based indicators like space per bird or measures of barn equipment. In favor of animal-based indicators the use of those evaluation systems were declined in recent years. In Germany, the Animal Protection Act (TierSchG 2017) obligates animal keepers to introduce and operate an on-farm-monitoring and controlling system to maintain and improve animal health and welfare, based on welfare-related, respectively animal protection, indicators ( $§ 11,8$ TierSchG).

The term animal welfare includes animal protection in this thesis (cf. $§ 11,8$ Lorz and Metzger 2019).

Thereby, liveweight development, mortality and foot pad lesions, for example, were discussed as suitable indicators. A continuous monitoring and evaluation of the flock data enables a target-performance comparison. The latter factor is fundamental for an indicator-based flock management. Compared to an audit by authorities which bases on limit values and possible penalties, an indicator-based system contains of a continuous target-performance comparison and threshold values, carried out by the flock manager. This approach requires knowledge about frames of risk, threshold values and target values as well. An indicator-based flock management aims to improve the environmental conditions of farm animals continuously and supports the farmers' responsibility. Furthermore, acceptance would be increased by using data which is already part of the documentation.

It was the objective of this thesis to work out target values and threshold values for the animal-based indicators mortality and foot pad health, to use them as part of the management of turkey flocks. Then, methods to monitor and evaluate foot pad health were assessed against the background of an objective, valid and reliable variable within an indicator-based flock management. Afterwards, possible management measures were proved in broiler flocks to prevent foot pad lesions and thus becoming a suitable management measure in poultry farming.

The first study (Chapter 3) was conducted on 13 turkey farms, located in North West Germany. Mortality and foot pad health were monitored and assessed in two consecutive turkey production cycles and both sexes and seasonal effects (winter cycle from October to March, summer cycle from April to September) were considered 
within the study. The animal stock of a farm could be divided in several flocks, each barn represented one individual flock and 37 flocks were monitored and evaluated. Foot pad health of a representative randomized sample of 60 birds was monitored and evaluated in a four-week interval in accordance to the 5-point scoring system of Hocking et al. (2008). Overall, data of 11,400 birds and 22,800 feet were collected and evaluated in this study and built data basis for the second study (Chapter 4). Furthermore, mortality and data of litter management were recorded continuously. During rearing the bedding material consisted of either wood shaving or straw pellet whereas all animals were kept on straw during fattening.

It could be pointed out that the first week mortality rate was positive correlated to the overall mortality rate of the rearing period (Spearman $r=0.677 ; \mathrm{p}<0.01$ ). So 7-day mortality indicates the necessary intensity of the further flock management and possible implications of additional management measures. Furthermore, it is important to supply the mortality data with placing the five week old birds on a separate fattening farm because managers of the fattening stock need to implement further measures as well, if required. A seasonal effect could be proved, mortality of male flocks increased about $0.5 \%$ in summer time compared to the winter cycles. Time frames of higher risk for mortality were identified around 14 to 15 weeks of age for all seasons and additionally around 12 to 13 and 20 to 21 weeks of age during summer season. The data were outlined as quartiles which enables the presentation of threshold values and risk frames for mortality and also target values for mortality as an indicator for environmental and management conditions in turkey husbandry.

Regarding the indicator 'foot pad health', the study pointed out the first eight weeks of age as a time frame of higher risk for foot pad lesions. Sex and season had no effect. At time of slaughtering again no effect of sex was found (median female avg. score 2.32 vs. male avg. score 2.35; score 0 to 4 in accordance to Hocking et al. 2008).

The evaluation of litter management data of male flocks figured out the variables 'weekly litter dispersing frequency' and 'litter amount in fattening period' to be mostly associated with the prevalence and severity of foot pad lesions, while the effect of litter amount was significant $(\mathrm{p}=0.0129)$. An incident related dispersing interval required up to $50 \%$ less material ( 11.2 to 14.2 vs. 17.5 to $22.6 \mathrm{~kg}$ straw $/ \mathrm{m}^{2}$ per cycle) and 
dispersing dates ( 2 to 3 vs. 4 to 6 times/ week per cycle) compared to a continuous interval and supported foot pad health (Median FPD score 2.2 vs. 2.7).

The objective of the second study (Chapter 4) was to evaluate the assessment method of 'foot pad health' against the background of using 'foot pad health' as an indicator for turkey welfare. Foot pad data were monitored as described in the first study. Both feet of an individual were monitored and the correlation between right and left foot of an individual was calculated. The results showed that the correlation between right and left foot of an individual ranged between $r=0.355$ to $r=1.000$ (Spearman Rho). So the recommendation for an early warning system within flock management could be to monitor both feet of an individual and the evaluation of the foot which is altered most. The required sample size was calculated for different confidence intervals $(\alpha=0.01$, $0.05,0.1)$, flock sizes and expected prevalence of foot pad lesions. The calculation of the required sample size of food pads figured out that 77 birds should be assessed in a flock of 4,000 birds and an expected prevalence of $40 \%$ within $10 \%$ confidence interval. Recommendations for the application in the field would be to vary sample size in dependence of the expected FPD prevalence. Target values for planning until eight weeks of age were published in Figure 4.

Another objective of that study was the comparison between histological and macroscopic assessment of foot pad health. Therefore 30 foot pads from slaughtered male turkeys were investigated in accordance to the macroscopic scheme of Hocking et al. (2008). Tissue samples from the center of the metatarsal pad were removed and fixed in formic acid (10\%) for 24 hours. After hematoxylin/eosin staining the samples were examined under a light microscope and the histopathological characteristics of epidermis and dermis were investigated. To examine the size of a foot pad lesion and compare a manual method (i.e. subjective method) with a technical (objective) method the image processing system Image J $1.51 \mathrm{k}$ was used. The size of the metatarsal pad as well as the size of alterations were measured with the photographic image system. The dimensions of the alterations were categorized according to the scheme of Hocking et al. (2008).

Moderate ulcers were already found in metatarsal foot pads which were manual assessed with score 1 and score 2 . Therefore, first lesions must be detected in a flock and a scoring system is used which separates Score $0=$ no lesions from macroscopic 
first lesions. That enables an early implementation of measures if needed. Another point is the feedback of scar tissue, which should be categorized as a separate score. It is an important and possible motivating information to the flock manager due to scar tissue reflects the success of management measures while still indicating a time frame of critical housing or management conditions during the husbandry period.

The comparison between the manual macroscopic scoring and the image-based program resulted in an increasing of alterations for the manual scoring. The so called 'optical illusion' is responsible for the results and supports the application of an external standard and, if possible, technical-based assessment systems. Furthermore, a standard definition to the boundary of the metatarsal pad is required because the metatarsal pad is directly related to the size of foot pad lesions.

Finally, it should be considered that the assessment scheme from Hocking et al. (2008) was developed for the manual assessment at time of slaughter. As the study shows onfarm foot pad assessment and also new techniques at slaughterhouse require different as well as new standard foot pad Scoring systems.

In the third study (Chapter 5) an established management procedure in the US Poultry production was proved for its suitability to prevent foot pad lesions under European/ national requirements for broiler housing conditions. The application of a sodium bisulfate product (SBS) was tested in a field study as a litter additive. Additionally, to performance data of the birds' litter parameters ( $\mathrm{pH}$ value and dry matter content) as well as ammonium $\left(\mathrm{NH}_{4}-\mathrm{N}\right)$ were investigated. Therefore, two application rates of the litter treatment were examined in two experiments on a commercial farm with two barns. Each cycle consisted of one barn with an SBS treatment (TRT) and one group without any litter treatment (Con). SBS was spread on top of the litter (spelt granulate) 20 hours before chick placement with either $250 \mathrm{~g} / \mathrm{m}^{2}$ (TRT 1) or $150 \mathrm{~g} / \mathrm{m}^{2}$ (TRT 2) in the treatment group. The performance data of liveweight, foot pad health and hock burn were recorded weekly on a randomized collected sample of 60 birds in accordance to the Welfare Quality Assessment System. Litter was sampled weekly in three different areas in the barns, around drinker line, feeder line and within the activity area.

No influence was proved on birds' liveweight $(\mathrm{p}=0.687$ and $\mathrm{p}=0.890)$. Mortality rate increased in TRT groups compared to control groups (TRT $12.79 \%$ vs. Con $2.03 \%$; 
TRT $22.88 \%$ vs. Con $2.27 \%$ ). The prevalence of foot pad alterations was significantly lower in the TRT groups compared to the groups without any litter treatment (p.m. $\mathrm{p}=0.011$ and $\mathrm{p}=0.000)$ and more SBS $\left(250 \mathrm{~g} / \mathrm{m}^{2}\right)$ supported foot pad health best. The incidence of hockburn was not affected by the TRT (p.m. $p=0.200$ and $p=0.115$ ) but by dry matter content $(\mathrm{p}=0.037)$. The reduction of the litter $\mathrm{pH}$ in the beginning of the cycle from $\mathrm{pH} 6$ in the control group compared to $\mathrm{pH} 1.7$ (TRT 1) and 2.0 (TRT 2) seems to be a suitable management measure to prevent or reduce foot pad dermatitis under European commercial husbandry conditions.

The results show that an assessment and benchmark of poultry flock data needs to consider seasonal and age effects. More than one cycle is needed to evaluate animal welfare and the potential risk of a conspicuous farm. The studies pointed out time frames of risk, target and threshold values for mortality and foot pad health, which are essential for knowing risks in time. The data can be used within on farm controlling of turkey and broiler flocks and foot pad health indicates status quo of care, housing, feeding and activity (see legal requirements $\$ 2$ German Animal Welfare Act; TierSchG 2017).

Animal welfare indicators need to be monitored and assessed since birds are placed as one day old chicks. A continuous improvement of housing conditions requires the transfer of data between rearing and fattening units. Only a feedback system between both production units enables manager from rearing and fattening birds to know the success of implemented and the possible need of other management measures. This practice assumes the same assessment methods during the husbandry period; first approaches can be derived from the present thesis. 


\section{Index of abbreviations}

\begin{tabular}{|c|c|}
\hline$\alpha$ & Alpha \\
\hline avg. & Average \\
\hline B.U.T. & British United Turkeys \\
\hline B.U.T. TP & British United Turkeys test product \\
\hline $\mathrm{cd}$ & Cell detritus \\
\hline cf. & Compare \\
\hline CLK & Cruse Lappelmann Kognitionstechnik \\
\hline Con / CON & Control group \\
\hline $\mathrm{CP}$ & Crude Protein \\
\hline $\mathrm{CV}$ & Coefficient of variation \\
\hline $\mathrm{d}$ & Day \\
\hline $\mathrm{DE}$ & Deutschland, engl.: Germany \\
\hline DL & Drinker Line \\
\hline DM & Dry matter \\
\hline e.g. & For example (exempli gratia) \\
\hline $\mathrm{EU}$ & European Union \\
\hline FA & Free Area \\
\hline FL & Feeder Line \\
\hline FM & Fresh Mass \\
\hline $\mathrm{FP}$ & Foot Pad \\
\hline FPD & Foot Pad Dermatitis \\
\hline $\mathrm{g}$ & Gramm \\
\hline $\mathrm{HCl}$ & Hydrogen chloride \\
\hline i.e. & That means (id est) \\
\hline 1 & Liter \\
\hline IQR & Interquartile range \\
\hline $\mathrm{LT}$ & Day of life \\
\hline LW & Liveweight \\
\hline
\end{tabular}




\begin{tabular}{|c|c|}
\hline LWo & Week of life \\
\hline M & Millions \\
\hline MJME & Megajoule Metabolizable energy \\
\hline Mort & Mortality \\
\hline $\mathrm{n}$ & Number \\
\hline $\mathrm{N}$ & Nitrogen \\
\hline $\mathrm{NH}_{3}$ & Ammonia \\
\hline $\mathrm{NH}_{4}$ & Ammonium \\
\hline No & Number \\
\hline PLT & Poultry Litter Treatment \\
\hline p.m. & Post mortem \\
\hline QS & Quality Assurance System \\
\hline $\mathrm{r}$ & Correlation coefficient \\
\hline $\mathrm{R}^{2}$ & Coefficient of determination \\
\hline SBS & Sodium Bisulfate \\
\hline $\mathrm{sc}$ & Summer cycle \\
\hline $\mathrm{SD}$ & Standard deviation \\
\hline SE & Standard error \\
\hline s.g. & So-called (so genannt) \\
\hline St.c. & Stratum corneum \\
\hline St.i. & Stratum intermedium \\
\hline $\operatorname{TRT}(1 / 2)$ & Treatment \\
\hline viz. & Videlicet \\
\hline wc & Winter cycle \\
\hline WHC & Water Holding Capacity \\
\hline wk & Week \\
\hline WRC & Water Releasing Capacity \\
\hline
\end{tabular}




\section{Index of Tables}

Table 1: Partial overview of species specific legal regulations for Broilers and recommendations for Turkeys in the European Union (EU) and Germany (DE) ....... 3 Table 2: Criteria of Five Freedoms FAWC, from Brambell's Report (FAWC 2009). 4 Table 3: Target and threshold values and status quo of the parameter Mortality (in \%)

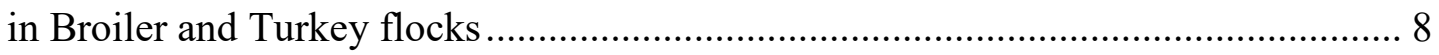

Table 4: Foot pad assessment schemes for Broilers and Turkeys (on-farm and p.m.)

Table 5: Legal Requirements for the manual foot pad assessment of broiler batches at slaughter house

Table 6: Selected studies about the animal health' and environmental effects of sodium bisulfate litter treatment in broiler flocks

Table 7: Mortality of birds in different stages of life depending on sex and season (Median and Interquartile range (IQR))

Table 8: Arithmetic mean (Mean), Grouped median (Median) and Standard deviation (SD) of foot pad scores on farms (week 1 until 16) and at slaughterhouse (post mortem, p.m.) depending on sex and season

Table 9: Correlation between the right and left foot of an individual bird ( $\mathrm{r}=$ bold values); flocks divided by sex (summarized sample 11,400 pairs from 13 farms $=37$ flocks)

Table 10: Calculated number of birds to be monitored and evaluated depending on flock size, prevalence of footpad alterations, confidence interval $(\alpha 0.1=90 \%, 0.05$ $=95 \%$, and $0.01=99 \%$, respectively) and proposed standard.

Table 11: Examples of macroscopic and histological observations of foot pads with different levels of foot pad lesions.

Table 12: Calculation and description of macroscopic foot pad alterations (green line: $100 \%$ metatarsal pad; red line: detected necrotic (black) area; blue line: scars; three samples/figure; mean value (pixel) and coefficient of variation (CV)). 79

Table 13: Broiler performance of SBS flocks and control flocks in treatment 1 (TRT1) and 2 (TRT2) at different times (d) (weight: $\mathrm{n}=60$ birds/date and each group; 
Table 14: Occurrence of foot pad lesions (\%) and hock burn (\%) in treatment 1 (TRT1) and 2 (TRT2) depending on bird's age (score 1/2 and 3/4 were pooled for paper presentation)...

Table 15: Litter parameter $\mathrm{pH}$ and dry matter content (\%) depending on sampling date and sampling area; 'Drinker Line' (DL), 'Feeder Line' (FL) and 'Free Area' (FA) $(\mathrm{SBS}=$ Sodium bisulfate; $\mathrm{CON}=$ control group) 


\section{Index of Figures}

Figure 1: Broiler foot pad with 4 digits (I to IV) and metatarsal fold as delimitation between metatarsal pad and tarsometatarsus

Figure 2: Average weekly mortality ( $\%$ of toms during winter cycle ( $\mathrm{n}=16$ flocks) 50

Figure 3: Average weekly mortality (\%) of toms during summer cycle ( $\mathrm{n}=14$ flocks)

Figure 4: Comparison of FPD-Scores between the right and left foot of an individual bird from the first to eighth week in \% ( $n=1,382$ pairs (1st week), 1,681 pairs (4th week), 2,013 pairs (8th week)) (where Score `0/0 means no FPD on left and right foot; 0/1 one foot of the pair with FPD Score 1 and the other Score 0, 1/1 both feet with FPD Score 1 and $>0 / 1 ; 1 / 1$ stands for at least one foot of an individual worse than Score 1)

Figure 5: Surface ratio green $=$ foot pad, red $=$ necrosis, fine yellow frame presents manually marked area; output number of pixels by Image $\mathrm{J} 1.51 \mathrm{k}$.

Figure 6: Ammonium-N (\%) in fresh mass (FM) within TRT1 (SBS=SBS250) at different areas $(\mathrm{DL}=$ Drinker Line, $\mathrm{FL}=$ Feeder Line, $\mathrm{FA}=$ Free Area)

Figure 7: Ammonium-N (\%) in fresh mass within TRT2 (SBS150) at different floor points $(\mathrm{DL}=$ Drinker Line, $\mathrm{FL}=$ Feeder Line, $\mathrm{FA}=$ Free Area $)$

Figure 8: Boundary of the metatarsal pad (green line) by the camera system (left;

Dummy of a turkey foot in a slaughterline, tagged by CLK Turkey Check) and manual assessment (right; freehand drawn)..... 


\section{Chapter 1 - General introduction}

\section{Development of German Poultry Husbandry}

Germany is the European leader in turkey meat production and one of the leading nations in European chicken husbandry. In 2016 about 93,79 M chicken were raised on about 3,330 broiler farms. Furthermore 12,36 M turkeys were reared and fattened on 1,848 turkey farms (Destatis 2017). While poultry meat consumption per capita increased to $20.9 \mathrm{~kg}$ in 2016 compared to $19.5 \mathrm{~kg}$ in 2014 and $17.8 \mathrm{~kg}$ in 2007 (Beck 2012; Beck 2017), the number of farms will probably decrease in future. In consequence a possibly reduced stocking density and a lack of new barns would increase the meat import (Lichter and Kleibrink 2016; Strüve et al. 2017). The widely held idea within German society of better animal welfare standards in foreign countries compared to German Agriculture is in contrast to researchers' assumption of a better welfare through higher vertical integrated poultry husbandry, as vertical integration increased in the German Poultry sector (Veauthier and Windhorst 2013; Lichter and Kleibrink 2016).

Concurrently, an increase of better animal husbandry conditions through new building projects is limited, among other things, by national restrictions of the privileged status of Agriculture within the construction law or difficult conditions for outdoor climate buildings and free range systems, particularly with regard to environmental aspects (BauGB 2017; WBA 2015).

Improvements in chicken husbandry and environmental conditions in chicken welfare were introduced by the European Union by the 'Laying down minimum rules for the protection of chicken kept for meat production' (European Union 2007). This European law rules the minimum standards of chicken husbandry. Furthermore, an EU Directive for turkey husbandry was published for EU member states, which is less mandatory than a recommendation (European Union 2002; Lichter and Kleibrink 2016).

Since 2006 the national legal framework of poultry husbandry is mainly regulated by the German Animal Protection Act (TierSchG 2017) and the statutory order for housing and environmental conditions of farm animals, e.g. broiler in particular (TierSchNutztV 2017). From 1999 up to that time the national minimum standard for 
chicken and turkey husbandry was recorded by the 'Federal voluntary agreement of chicken and turkey husbandry' (BML 1999). National species specific regulations for turkey husbandry are still based on the 'Federal voluntary agreement of turkey husbandry' which had to be updated in 2018 (VDP 2013). In comparison to legal regulations a voluntary agreement enables a fast transfer of scientific findings on farm level. In Lower Saxony turkey husbandry is regulated by a circular decree from 4th December 2014, which is referred to the federal voluntary agreement (Nds. MBI 2014b).

The primary national regulations concerning stocking density of chicken changed from $35 \mathrm{~kg} / \mathrm{m}^{2}$ (BML 1999) to a maximum of $39 \mathrm{~kg} / \mathrm{m}^{2}$ (TierSchNutztV 2017), which is $3 \mathrm{~kg}$ less than the maximum of EU directive (RL 2007/43/EG; European Union 2007). Common housing conditions for chicken are forced-ventilated barns, whereas turkeys are mostly kept in open barns with natural air flow and circulating fans (Berk 2017; Toppel et al. 2016). Chicken and turkey as well needs to be kept on fresh, new, dry bedding material, as listed in Table 1. Herd managers are responsible for a good bedding during husbandry period, thus litter enables birds to scratch, peck and dust bathing (Berk 2017; TierSchNutztV 2017; VDP 2013). Animal needs and certain behaviors became a more important concern over the time (cf. Welfare Issues in Poultry Husbandry - Terms and Defintions).

The main issues being addressed in turkey production are the ban of beak trimming, the reduction of stocking density, alternative housing systems and the implementation of certain management measures regarding litter, feeding and environmental enrichment, for example (ML 2011; WBA 2015). In order to find out possible approaches to keep livestock under those altered conditions, several measures are tested within the scope of different national programs, for example the 'Animal Welfare Plan of Lower Saxony' (ML 2011). This Welfare Plan exceeds the latter standards. The work schedule was established by the state government in 2011 to improve and develop animal welfare in livestock husbandry (Petermann et al. 2017). For example, elevated resting-places and separate resting areas were proved to enable perching and to increase the level of activity. Furthermore, foot pad health strategies and management of non-beak trimmed turkeys, which should be implemented from 
2019 in female turkey flocks, are major topics of the 'Welfare Plan' (Petermann et al. 2017).

Table 1: Partial overview of species specific legal regulations for Broilers and recommendations for Turkeys in the European Union (EU) and Germany (DE)

\begin{tabular}{|c|c|c|c|c|}
\hline & \multicolumn{2}{|c|}{ Broiler } & \multicolumn{2}{|c|}{ Turkey } \\
\hline & $\mathbf{E U}$ & DE & $\mathbf{E U}$ & $\mathbf{D E}$ \\
\hline Regulation & $\begin{array}{l}\text { Legislation } \\
\text { (EU 2007) }\end{array}$ & $\begin{array}{c}\text { Legislation } \\
\text { (TierSchNutztV } \\
\text { 2017) } \\
\text { Decree (Nds. } \\
\text { MBI 2018)* }\end{array}$ & $\begin{array}{l}\text { Recommendations } \\
\text { (EU 2002) }\end{array}$ & $\begin{array}{l}\text { Recommendations } \\
\text { (VDP 2013) } \\
\text { Decree (Nds. MBI } \\
2014 \mathrm{~b})\end{array}$ \\
\hline $\begin{array}{l}\text { Stocking } \\
\text { density }\end{array}$ & $\begin{array}{l}33- \\
42 \mathrm{~kg} / \mathrm{m}^{2}\end{array}$ & $35-39 \mathrm{~kg} / \mathrm{m}^{2}$ & $\begin{array}{l}\text { no maximum } \\
\text { value }\end{array}$ & $\begin{array}{l}\text { of } 50 / 58 \mathrm{~kg} / \mathrm{m}^{2} \\
\text { क } 45 / 52 \mathrm{~kg} / \mathrm{m}^{2}\end{array}$ \\
\hline Litter & $\begin{array}{l}\text { dry and } \\
\text { friable } \\
\text { surface }\end{array}$ & $\begin{array}{l}\text { dry and friable, } \\
\text { for pecking, } \\
\text { scratching and } \\
\text { dustbathing }\end{array}$ & $\begin{array}{l}\text { dry and friable } \\
\text { litter for plumage } \\
\text { care and } \\
\text { dustbathing, for } \\
\text { environmental } \\
\text { enrichment and } \\
\text { against abnormal } \\
\text { behavior, } \\
\text { reducing FPD }\end{array}$ & $\begin{array}{l}\text { dry and friable } \\
\text { surface, for } \\
\text { appropriate } \\
\text { conditions } \\
\text { (pecking, } \\
\text { dustbathing), } \\
\text { reducing FPD }\end{array}$ \\
\hline $\begin{array}{l}\text { Manipulable } \\
\text { material }\end{array}$ & & \multirow[t]{2}{*}{$\begin{array}{l}* \text { one } \\
\text { material } / 150 \mathrm{~m}^{2}\end{array}$} & & $\begin{array}{l}\text { obligate; litter } \\
\text { material plus } \geq 1\end{array}$ \\
\hline $\begin{array}{l}\text { Environ- } \\
\text { mental } \\
\text { Enrichment }\end{array}$ & & & see above (litter) & recommended \\
\hline $\begin{array}{l}\text { Corrosive } \\
\text { gases } \\
-\quad \mathrm{NH}_{3} \\
-\quad \mathrm{CO}_{2}\end{array}$ & \multicolumn{2}{|c|}{$\begin{array}{l}\text { Limit value: } \\
\begin{array}{l}\text { - } \quad 20 \mathrm{ppm} \\
\text { - } \quad 3,000 \mathrm{ppm}\end{array}\end{array}$} & $\begin{array}{l}\text { 'harmless } \\
\text { concentrations' }\end{array}$ & $\begin{array}{l}\frac{\mathrm{NH}_{3}}{\text { aim: }:<10} \\
\text { permanent }<20 \\
\frac{\mathrm{CO}_{2}}{\text { no permanent }} \\
\text { exceed }>3,000\end{array}$ \\
\hline
\end{tabular}

However, requirements to animal protection and animal welfare need to be standardized at least in the European Union, as an increased demand for poultry meat is associated with more trade in poultry meat (v. Horne and Achterbosch 2008; Lichter and Kleibrink 2016). So far, major differences are known and should not lead to competitive disadvantages in countries with higher animal welfare standards (Lichter and Kleibrink 2016). 


\section{Welfare Issues in Poultry Husbandry}

\section{Terms and Definitions}

Legislations and social attitude towards husbandry animals have been influenced strongly by the Brambell Report, which was published in 1965 in the UK, even though there was no official link to the Report and European legislation (Brambell 1967, Veissier et al. 2008). Within the Brambell Report the 'Five Freedoms' were stated, in particular animals should have freedom to stand up, lie down, turn around, groom themselves and stretch their limbs. In consequence of the report the Farm Animal Welfare Council (FAWC) developed welfare criteria for farm animals, derived from Brambell's 'Five Freedoms', and considering the physical and mental state of farm animals (Table 2) (FAWC 2009).

Table 2: Criteria of Five Freedoms FAWC, from Brambell's Report (FAWC 2009)

\begin{tabular}{|l|l|}
\hline Criteria - Five Freedoms & Necessary Condition \\
\hline Freedom from Hunger and Thirst & $\begin{array}{l}\text { Ready access to fresh water and a diet to } \\
\text { maintain full health and vigor }\end{array}$ \\
\hline Freedom of Discomfort & $\begin{array}{l}\text { Providing an appropriate environment } \\
\text { including shelter and a comfortable } \\
\text { resting area }\end{array}$ \\
\hline Freedom from Pain, Injury or Disease & $\begin{array}{l}\text { Prevention or rapid diagnosis and } \\
\text { treatment }\end{array}$ \\
\hline Freedom to Express Normal Behavior & $\begin{array}{l}\text { Providing sufficient space, proper } \\
\text { facilities and company of the animal's } \\
\text { own kind }\end{array}$ \\
\hline
\end{tabular}

To improve animal protection and enhance animal welfare in Europe the Treaty of Amsterdam came into force on $1^{\text {st }}$ May 1999 (Veissier et al. 2008). This treaty was followed by the Lisbon Treaty from 2009. The Animal Welfare Protocol was raised to a separate article, which was signed by all EU member states. Respect from humans towards all animals was strengthened by defining animals as 'sentient beings' 
(Beaumont et al. 2010). Nevertheless, animal protection is a national objective and in Germany, animal protection is statutorily-regulated by the Animal Protection Act (TierSchG 2017). While Animal Protection describes 'animal husbandry conditions which are human-determined', the term Animal Welfare comprises how the animals are coping with the conditions in which they live (Broom 1986, OIE 2011). According to Fraser (2008), a description of Animal Welfare should consider the three concepts, which are 'basic health and functioning' meaning freedom of disease and physical health; 'natural living', which focuses on the possibility of exert normal behavior and 'affective states', which mainly concerns (absence of negative) emotions (Broom and Fraser 2007; Fraser 2008; Mondon et al. 2017). Pursuant to the Terrestrial Animal Health Code, the state of good welfare is linked to health, comfort, good nutrition, safety, the ability to express innate behavior and freedom from pain, fear and distress (OIE 2011). Another term, the German term 'Tierwohl = Animal Welfare' seems to be a more complex and mainly a marketing term that probably supports consumers' acceptance towards welfare-oriented programs and husbandry systems (Puppe 2016; Mondon et al. 2017). The German term 'Tiergerechtheit' would describe two aspects: the impact of housing conditions on birds' physical integrity and how much the environment enables the bird to be free from pain, injury and suffer. The term would also express the grade of welfare, which is given by an appropriate facility to enable the bird to perform natural behavior (Knierim 2001; Mondon et al. 2017; WBA 2015). This includes more than only the physical state of health (WBA 2015). Hence, health is not equal to welfare but it is part of animals' welfare (Broom 2007). Pain, (harm) and suffering are important aspects of poor welfare (Broom 2007). Lorz and Metzger (2008) modified the definition for pain from IASP-Pain terms (Merskey and Bogduk 1994) and described pain as an "[...] unpleasant sensory and emotional experience with current or potential tissue damage or which may describe in terms of such damage." (Merskey and Bogduk 1994). According to Tschanz' concept of 'Meet Demands and Avoid Damage', behavior of an animal provide self-maintenance and enables it to fulfil its demands as well as prevents itself from damage (Tschanz 1987). Based on that assumption animals use or avoid structures in their environment. The fulfillment of animals' needs must be ensured by stockmen. To meet the needs and satisfactions of an animal is a key issue of animal welfare (Mondon et al. 2017). 
Therefore, certain parameters and indicators are needed. The earlier approach of only resource- and management-based assessment of housing and environmental conditions, e.g. litter material and space was enhanced and improved by an animalbased assessment (Butterworth 2013). Since February 2014 herd managers and animal owners are required to introduce and operate an on-farm controlling system, based on animal welfare indicators, to improve animal welfare at farm level (Lorz and Metzger 2019; TierSchG 2017). A controlling system enables herd managers to derive measures from the status quo assessment, and furthermore to get a feedback of success of the implemented measurements (Candiani et al. 2008, Toppel et al. 2013). Indicators should be objective, feasible, reliable and valid (Veissier et al. 2013). Indicators in herd management should reduce the effort of on-farm-monitoring. Compared to a parameter or measure an indicator signals a status quo of a process and, at most, reacts to different impacts. A parameter is measurable and lots of parameters sustain an indicator. That points out the advantage in daily flock management, as less time is needed and more information is given by an indicator based assessment (Edtmayr et al. 2016). The evaluation of a signal from an indicator requires target-values as well as a corridor of tolerable deviations. A range or corridor considers farm individual and environmental aspects like season or feed, what makes them more likely compared to a constant value. Target values differ from limit-values, as the latter term is part of the quantitative risk management to prevent diseases and guarantee a minimum standard of animal welfare within the legal framework. To exceed a limit-value is probable related with relevant health and welfare problems. For example, statutory limits exist to mortality (Nds. MBI 2014a, TierSchNutztV 2017). Mortality is correlated with health or rather disease and further information is given by parameters such as number of dead animals/ mortality rate, species or age. Further indicators for on-farmmonitoring and flock assessment, like development of bodyweight and foot pad health, were published from Knierim et al. (2016). As a standardized European System, the Welfare Quality ${ }^{\circledR}$ Protocol contains on-farm indicator-based welfare assessment (Welfare Quality ${ }^{\circledR} 2009$ ). However, the turkey species was not considered yet within a European Standard like the Welfare Quality ${ }^{\circledR}$ Protocol, suitable indicators are needed and still need to be assessed scientifically (Mondon et al. 2017). 


\section{Welfare Concerns}

Several welfare problems are associated with broiler and turkey husbandry. Major issues, which were pointed out could be divided by genetic factors like high early growth rate and diseases, skeletal disorders and locomotor activity as well as environmental factors like lighting, litter and air quality, environmental enrichment and stocking density (Bessei 2006, Glatz and Rodda 2013).

\section{Mortality}

Mortality is not only a financial disaster within broiler and turkey husbandry but even more a welfare concern (Butterworth et al. 2015, Julian 2004). Farm animal welfare requires protection of animals from pain, injuries and suffer and, if needed, animal keepers and flock managers are obligated to cull them. Mortality also is a useful indicator of husbandry conditions or infection within the flock. In accordance to the German Order on the Protection of Animals and the Keeping of Production Animals (TierSchNutztV 2017) the legal limit value for daily mortality in Broiler flocks is $0.3 \%$ until the age of 11 days with a case-by-case tolerance to $0.6 \%$ (Nds. MBI 2014a). The maximum cumulative mortality from day 1 to 10 is $2.0 \%$ (Nds. MBI 2014a). Furthermore, the following term covers cumulative mortality: $(1.0 \%+0.06 \%$ x days of age) x 1.5 (Nds. MBI 2014a). Moreover, a documentation of daily and cumulative mortality rate is needed within flock management (TierSchNutztV 2017). In accordance with national animal disease legislation a farmer must inform a veterinarian if mortality for a 24 hour period exceeded $2 \%$ (GeflPestSchV 2016). The application of mortality as an animal welfare related indicator requires target and threshold values. Reference values are shown in Table 3. Within an indicator-based management of broiler and turkey flocks those data should be interpreted in association with drug treatment (Andersson et al. 2015), which is cited a suitable welfare-related indicator in reference to the Medicinal Products Act (1.6.2, Nds. MBI 2014b). 
Table 3: Target and threshold values and status quo of the parameter Mortality (in \%) in Broiler and Turkey flocks

\begin{tabular}{|c|c|c|c|c|c|}
\hline & Target value & Thresl & d value & \multicolumn{2}{|c|}{ Actual mean } \\
\hline \multicolumn{6}{|l|}{ Broiler } \\
\hline day 1 to 7 & $<1^{3}$ & - & \multirow{2}{*}{$4.0^{5}$} & \multirow{2}{*}{\multicolumn{2}{|c|}{$4.2^{4}$}} \\
\hline day 7 to slaughtering & $0.06 \% /$ day $^{3}$ & $4.0^{3}$ & & & \\
\hline \multicolumn{6}{|l|}{ Turkey } \\
\hline female - rearing & - & \multirow{2}{*}{\multicolumn{2}{|c|}{$4.0^{5}$}} & $1.8^{2}$ & \multirow{2}{*}{$3.9^{1}$} \\
\hline female - fattening & - & & & $3.5^{2}$ & \\
\hline male - rearing & - & \multirow{2}{*}{\multicolumn{2}{|c|}{$10.0^{5}$}} & $2.4^{2}$ & \multirow{2}{*}{$10.3^{1}$} \\
\hline male - fattening & - & & & $8.6^{2}$ & \\
\hline
\end{tabular}

${ }^{1}$ Schmitz-Dumont and König (2014); ${ }^{2}$ Toppel et al. (2016); ${ }^{3}$ De Gussem (2013);

${ }^{4}$ Damme (2017); ${ }^{5}$ Rautenschlein and Ryll (2014)

From legislative perspective, the status of health is coupled with stocking density. While the European Directive of broiler welfare determined the maximum stocking density on $33 \mathrm{~kg} / \mathrm{m}^{2}$, it is possible to increase stocking density if certain health conditions, like low mortality in broiler flocks, can be proven (European Union 2007). Furthermore fattening mortality is used as a suitable indicator for continuous flock assessment and benchmark within the German Turkey Health Control Policy (Andersson et al. 2015). As a consequence of conspicuous flocks, associated with failures in flock management, the maximum stocking density can be reduced by authorities (Meyer 2015). However, no influence from stocking density to mortality in broiler flocks were found, for example, by Guardia et al. (2011), Buijs et al. (2009) and Meluzzi et al. (2008). Moreover, Estevez (2007) and Dawkins et al. (2004) emphasized the important meaning of management and environmental status to poultry health and welfare. As a result of an experimental study by Kulke et al. (2014) the authors could not prove an influence from stocking density on mortality in a flock with toms which were not beak trimmed. 
Main influences to early mortality were pointed out to be age of breeder stock, strain and hatchery (Yassin et al. 2009). Therefore, the necessity of intensive care and management within the first week of life is evident (Wojcinski 2014).

The effect of sex to late mortality was demonstrated, e.g. from Rudolf (2008). Male mortality was $14.6 \%$ compared to $5.6 \%$ in female flocks. Those data were monitored during summer time, and heat stress was proved as an substantial issue for an increase of mortality rate, especially in male flocks (Clark and Bailey 2014; Evans et al. 2000). According to Spindler (2007), heat stress leads to cardiovascular disorders and also increased risk of mortality due to severe pecking and cannibalism. Berg (2002) expected a negative effect on mortality in turkey flocks due to feather pecking and cannibalism in consequence of the ban of beak trimming. However, this could not be proven in an experimental study of Kulke et al. (2014). 'Sudden death' was pointed out to be another problem, especially between weeks $8^{\text {th }}$ to $14^{\text {th }}$ (Hafez 2006). Within a survey with German turkey experts 'Diseases' were predicted as most causative for mortality of hens and toms during fattening (Toppel et al. 2016). That was explained by the experts as a consequence of the expected reduction of medication, in particular antibiotics. Furthermore, a demand for open-housing systems and an ongoing high likelihood of infection in intensive production areas may cause diseases in turkey production systems. That would comply with Pedersen et al. (2003), who expect a higher mortality in organic compared to conventional husbandry systems due to demands for access to free range area and limitations in feed additives. The authors evaluated in their Danish study $3.8 \%$ mortality rate in conventional broiler farms compared to $6.0 \%$ in flocks from farms using high ecological standard. The long husbandry period of 81 days in organic broiler systems needs to be considered. Nevertheless, Pedersen et al. (2003) suggested coccidiosis and necrotic enteritis to be main reasons for mortality. These results are in contrast to Bokkers and De Boer (2009) who evaluated mortality in Dutch broiler flocks. The rate of losses was $2.8 \%$ in organic farms and $3.3 \%$ in conventional broiler flocks, which might be interpreted as equal mortality rates. On-farm broiler mortality from Norway is estimated at about $2.8 \%$ after 30 to 32 days (Animalia 2014). A higher mortality in chicken flocks due to ascites was published by Part et al. (2016), with an increased prevalence in winter time. That would also stress the seasonal influence on mortality in broiler flocks. 


\section{Foot pad dermatitis}

Foot pad health is another welfare related issue in turkey and broiler husbandry (De Jong et al. 2014, Youssef et al. 2010, Bessei 2006). Alterations on metatarsal pads of turkeys and chickens were proven for prevalence and severity. Up to $65 \%$ of turkeys showed altered foot pads at the end of the rearing period in the study of Bergmann et al. (2013). From that sample size, between 10 and $15 \%$ were affected by epithelial necrosis. Krautwald-Junghanns et al. (2011) investigated foot pad health within a field study. About $2.1 \%$ of male turkeys were without foot pad lesions at time of slaughtering compared to $0.6 \%$ of female turkeys. Those results are comparable with Allain et al. (2013) who pointed out that $99 \%$ of foot pads from 60 evaluated flocks were altered at the end of fattening. Spindler (2007) reported about more than $90 \%$ of male turkeys with pododermatitis at time of slaughtering.

Alterations at the plantar region of the feet can cause lameness and immobilization ( $\mathrm{Da}$ Costa et al. 2013, Hocking and $\mathrm{Wu} 2013$ ). However, results from the field study from Krautwald-Junghanns et al. (2009) showed hardly any FPD on immobile turkeys and severe immobile birds were mainly monitored without skin abnormality on foot pads. This was explained due to a possible long lasting period of laying instead of walking. Based on the assumption that severe foot pad lesions would lead to a change in activity and limit gait movement Hocking et al. (2017) applied three different analgesics to turkey toms. The results did not show a clearly significant effect, hence, injured foot pads do not mean a painful condition per se for a bird. Buda et al. (2002) indicated the relevance of welfare in context with foot pad lesions in their study. They proved the existence of sensory nerve endings from mechano- and pain receptors in the plantar area of feet. It could be concluded that deeper lesions would obviously be painful to the birds.

\section{Anatomical Structure - Foot pad}

The epidermal structure, as the outer layer of a foot pad, forms reticulate scales and consists of a multilayer squamos epithelium which is developed by horn cells (Vollmerhaus and Sinowatz 2004). In particular, papillary dermis is the upper most level of the dermis. Both, dermis and epidermis, form the typical scale-like structure whereby scales do not overlap (Platt 2004, Spindler 2007). The thick skin layer of 
reticulate scales consists of a high proportion of intracellular lipids which have cushioning effects. The skin layer is a barrier against infectious agents and physical and chemical irritations (Salomon 1993). Horn cells form the stratum corneum as part of the epidermis and flake off skin's surface continuously (Vollmerhaus and Sinowatz 2004). The adjacent located stratum intermedium consist of up to ten layers of intermediate cells, followed by the basal layer (Platt 2004, Spindler 2007). The metatarsal pad and digit pad are cushioned by the digit joints and the Pulvinus metatarsalis is located beneath the second to fourth digit (Nickel et al. 2004). The metatarsal pad is shown in Figure 1.

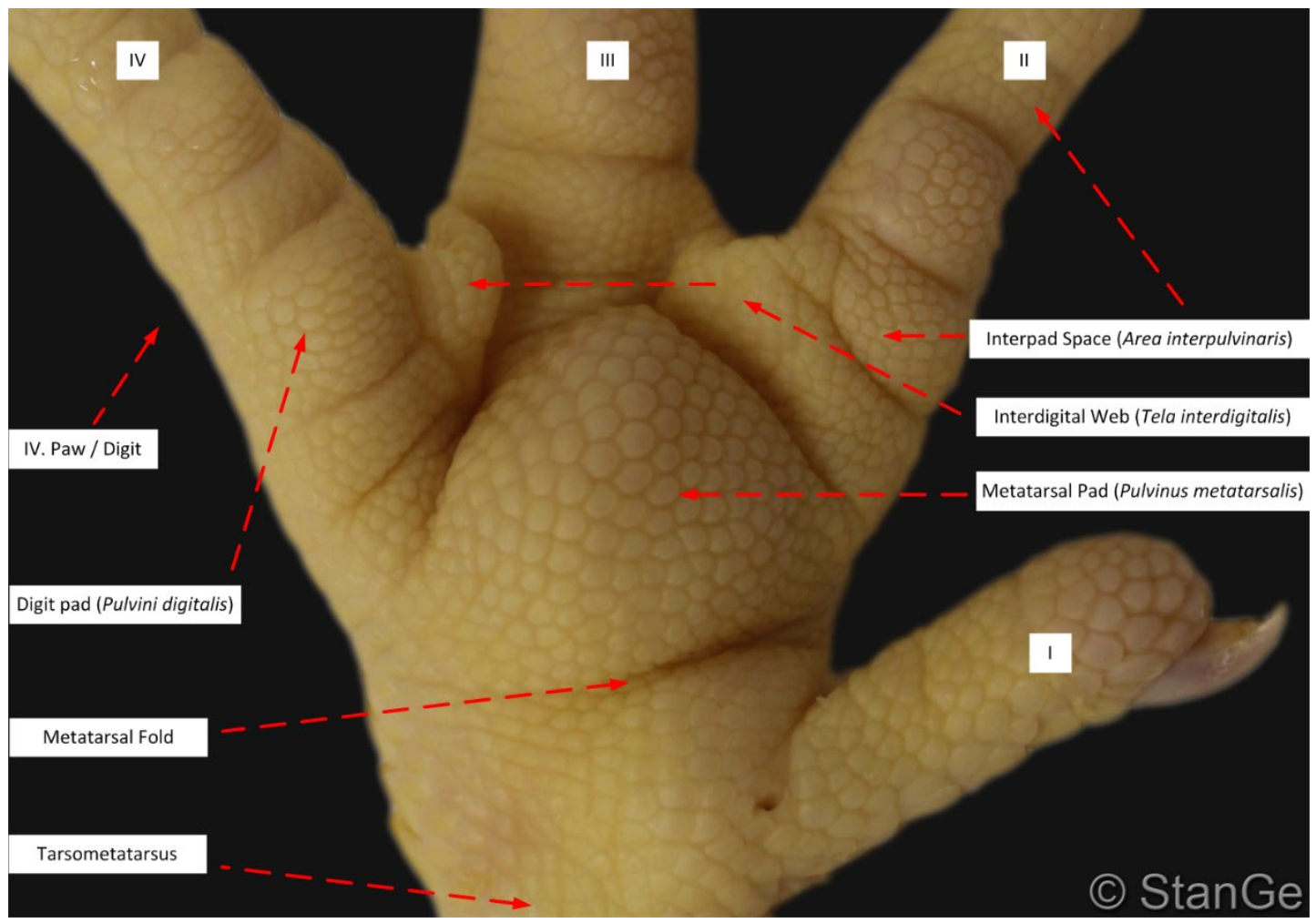

Figure 1: Broiler foot pad with 4 digits (I to IV) and metatarsal fold as delimitation between metatarsal pad and tarsometatarsus

\section{Macroscopic lesions}

The first macroscopic signs of a FPD are discoloration of the plantar surface, proliferative hyperkeratosis and scaly brown scabs (Hocking et al. 2008, Greene et al. 1985). In further progress rhagades and small necrotic scales become visible (Kamphues 2014). Reticulate scales flake off the surface area (Spindler 2007). This is usually followed by brightened scales which look like protruding villi due to strong 
separation. Dead cells could cover up the whole foot pad area. Crusts might cover the metatarsal and digital pad where litter material, feces and exudate adhere (Greene et al. 1985). A swollen foot pad can be caused by an abscess from inflammation, and in severe cases develop into a so called 'bumble foot'. Rudolf (2008) found macroscopic small necrotic alterations, but with inflammation and formation of exudative plaques, with severe lesions in histological investigation. The author concluded a similar inflammation process of FPD in general, which is independent from the size of an ulcer (Rudolf 2008).

The formation of scar tissue proves healing of pododermatitis on metatarsal and digital pads. Mayne et al. (2007a) investigated healing of foot pad lesions and scar tissue was formed after 15 days birds were kept on permanent dry litter material but hard scabs were still visible at those turkeys whose foot pads were infected most. Healing was characterized by a dissipated structure of the reticulate scales (Platt 2004). The area with scar tissue appeared smooth and bright (Michel et al. 2012). KrautwaldJunghanns et al. (2011) observed formation of scar tissue in week 16 on 1/3 of assessed foot pads in a field study.

\section{Histological lesions}

The skin of metatarsal and digital pads is clearly divided by subcutis, dermis and epidermis (Platt 2004). Histopathologic alterations were not evidently seen macroscopically so external unaffected feet can have cellular changes (Mayne et al. 2007a). In accordance to Mayne et al. (2007a) the histologic assessment of foot pad health was carried out in different grades. Mild changes were described as hyperkeratosis, epithelial hyperplasia and dead keratin on the foot pads' surface up to necrotic debris in keratin of the epidermis. Medium alterations included evidence of macrophages, lymphocytes and heterophils in the dermis and furthermore an increased amount of those blood cells and antibodies. A split epidermis and large lesions were categorized as severe lesions (Mayne et al. 2007a). Severe lesions have already been proved in turkeys after a 48 hour exposure to wet litter. Birds showed cellular changes and inflammation (Mayne et al. 2007a). In the run-up to formation of scar tissue the basal membrane was damaged (Rudolf 2008). Accompanying characteristics of scar tissue were an even stratum corneum and a dermis without remarkable primary 
papillae. Those results were similar to Michel et al. (2012), who investigated foot pads of broilers post mortem.

\section{Assessment schemes}

Foot pad assessment schemes primarily focus on the metatarsal pad and partly on digit pads as well. Macroscopic schemes differed to the schemes of a two-dimensional assessment (size of a lesion) and three-dimensional assessment (size and depth) (Lund et al. 2017). Furthermore, macroscopic and histologic assessment schemes were published with an overview shown in Table 4. The formation of scar tissue, as described by Platt (2004) and Rudolf (2008), was considered by Ekstrand et al. (1998) who added the criteria 'no scars' to the best evaluation point in their scheme. Furthermore, Michel et al. (2012) described scar tissue on broiler foot pad surface, but the authors would not recommend an evaluation of scar tissue in processing plants. Rudolf (2008) pointed out that the presence of scar tissue was associated with severe lesions and damages of the basal membrane in particular. Therefore, the evaluation of FPD could not result in a score which describes the absence of lesions if scar tissue is proved. Several schemes with different methods were published for an on-farm and post mortem (p.m.) monitoring and assessment of broiler and turkey flocks, see Table 4.

Table 4: Foot pad assessment schemes for Broilers and Turkeys (on-farm and p.m.)

\begin{tabular}{|c|c|c|c|}
\hline Species & Scale & Description & Reference \\
\hline \multicolumn{4}{|l|}{ macroscopic } \\
\hline Turkey & $0-3$ & $\begin{array}{l}\text { 0- no lesions } \\
\text { 3- severe large punched-out } \\
\text { ulcers }\end{array}$ & $\begin{array}{l}\text { Martland } \\
(1984)\end{array}$ \\
\hline Turkey & $1-11$ & $\begin{array}{l}\text { 1- no visible lesions } \\
11 \text { - scab formation whole foot } \\
\text { pad }\end{array}$ & Platt (2004) \\
\hline Turkey & $0-7$ & $\begin{array}{l}\text { 0-no visible signs of FPD; } \\
\text { normal skin of foot pad and } \\
\text { digital pads, no redness, } \\
\text { swelling or necrosis, soft skin } \\
7 \text { - foot pad }>1 / 2 \text { covered in } \\
\text { necrotic scales }\end{array}$ & $\begin{array}{l}\text { Mayne et al. } \\
(2007 \mathrm{a})\end{array}$ \\
\hline Turkey (p.m.) & $0-4$ & $\begin{array}{l}0-\text { no external lesions } \\
4->1 / 2 \text { of foot pad necrotic }\end{array}$ & $\begin{array}{l}\text { Hocking et al } \\
\text { (2008) }\end{array}$ \\
\hline
\end{tabular}


Table 4ff: Foot pad assessment schemes for Broilers and Turkeys

\begin{tabular}{|c|c|c|c|}
\hline Species & Scale & Description & Reference \\
\hline \multicolumn{4}{|l|}{ macroscopic } \\
\hline $\begin{array}{l}\text { Turkey } \\
\text { (grower) }\end{array}$ & $0-4$ & $\begin{array}{l}\text { 0- no alterations on foot pads } \\
\text { 4- profound lesions of plantar } \\
\text { skin, abscess, ablation of outer } \\
\text { layer of epidermis }\end{array}$ & $\begin{array}{l}\text { Bergmann et al. } \\
\text { (2013), ref. to } \\
\text { Mayne (2005) } \\
\text { and Hocking et } \\
\text { al. (2008) }\end{array}$ \\
\hline Broiler & $0-3$ & $\begin{array}{l}\text { 0- no lesions } \\
\text { 3- severe, large scab-filled } \\
\text { ulcers }\end{array}$ & $\begin{array}{l}\text { Martland } \\
\text { (1985) }\end{array}$ \\
\hline Broiler (p.m.) & $0-2$ & $\begin{array}{l}\text { 0- no lesion, mild } \\
\text { hyperkeratosis, no scars } \\
\text { 2- severe, deep lesions, scabs, } \\
\text { ulcers }\end{array}$ & $\begin{array}{l}\text { Ekstrand et al. } \\
\text { (1998) }\end{array}$ \\
\hline Broiler & $0-2$ & $\begin{array}{l}0 \text { - no lesion } \\
2 \text { - severe lesion, dark brown } \\
\text { crust }>7.5 \mathrm{~mm}\end{array}$ & $\begin{array}{l}\text { Bilgili et al. } \\
(2006)\end{array}$ \\
\hline Broiler (p.m.) & $0-5$ & $\begin{array}{l}\text { 0- no visible lesions } \\
\text { 5- severe pododermatitis }\end{array}$ & $\begin{array}{l}\text { Butterworth and } \\
\text { Haslam (2009) }\end{array}$ \\
\hline Broiler & $0-5$ & $\begin{array}{l}\text { 0- no lesions and discoloration } \\
5 \text { - big ulcer, }>80 \% \text { of plantar } \\
\text { foot pad covered by crust }\end{array}$ & Ask (2010) \\
\hline Broiler (p.m.) & $1-3$ & $\begin{array}{l}\text { 1- mild/ early stage of lesions } \\
\text { (enlarged scales, erythema, } \\
\text { hyperkeratosis) } \\
\text { 3- depressed lesions, ulcer, dark } \\
\text { thick crust }\end{array}$ & $\begin{array}{l}\text { Michel et al. } \\
(2012)\end{array}$ \\
\hline Broiler & 11 scores & $\begin{array}{l}0-2 b \text { for lesions at plantar foot } \\
\text { pad skin; } 2 b>0.5 \mathrm{~cm} \text { deep } \\
\text { lesion } \\
0-1 \text { skin fissures no/yes } \\
0-3 \text { hyperkeratosis; } 3>2 \mathrm{~mm}\end{array}$ & $\begin{array}{l}\text { Westermaier } \\
\text { (2015), ref. to } \\
\text { Welfare Quality } \\
\text { (2009) }\end{array}$ \\
\hline \multicolumn{4}{|l|}{ histologic } \\
\hline Turkey & $0-7$ & $\begin{array}{l}\text { 0- no change } \\
7 \text { - split epidermis; several } \\
\text { lesions or } 1 \text { very large lesion, } \\
\text { more than } 1 / 3 \text { of total sample }\end{array}$ & $\begin{array}{l}\text { Mayne et al. } \\
(2007 a)\end{array}$ \\
\hline Broiler & $1-3$ & $\begin{array}{l}\text { 1- up to moderate hyperplasia/ } \\
\text { hyperkeratosis of epidermis, } \\
\text { oedema, mild inflammatory } \\
\text { infiltration } \\
\text { 3- ulcer, granulation tissue }\end{array}$ & $\begin{array}{l}\text { Michel et al. } \\
(2012)\end{array}$ \\
\hline
\end{tabular}


The German legal requirement for broiler foot pad assessment at slaughterhouse is the counterpart of the Dutch, Danish and Swedish System. From each delivered flock 50 feet from the first third and 50 feet from the last third must be examined. Every foot is given a score between 0 and 2 . The score depends on the level of alterations (DVFA 2017, Appendix 17 TierSchNutztV 2016, De Jong et al. 2012, Odén 2011). The 3scale scoring system is based on Ekstrand et al. (1998) (De Jong et al. 2012b). Nevertheless, there are differences in the application of foot pad assessment. Contrary to the German system, which primarily focuses on the size of the necrotic area on the plantar area of foot and digit pads, the Dutch assessment scheme classifies an obvious deep dark necrotic area, which covers only a $1 / 4$ of a foot pad for example, as score 2 due to the assumption of an ulcer (De Jong et al. 2012). Furthermore, a severe swollen foot pad results in score 2 as well (De Jong et al. 2012). On the other hand, a foot pad with superficial discoloration of the skin, which would cover $100 \%$ of the skin, will be classified as score 1 in a Dutch slaughterhouse compared to score 2, following the German scoring system (Nds. MBI 2014a, De Jong et al. 2012).

Some national Guidelines include a further classification, based on the following formula (De Jong et al. 2012): Flock FPD score $(\%)=100 \times[(0.5 \times$ the total number of feet classified Score 1$)+(2 \times$ the total number of feet classified score 2$)] /$ total number of scored feet. In conclusion, a flock can range between 0 (100\% of the scored feet had no lesions) to 200 (all feet were classified in score 2).

In consequence of the latter classification the abattoir would act as follows: 0 to $\mathbf{4 0}$ points = no interaction; 41 to 80 points $=$ producer needs to correct management deficiencies; results of the next flock will be observed by slaughterhouse veterinarian and, if necessary, reported to veterinarian inspection unit; potential measures could be a reduced stocking density; $\mathbf{8 1} \mathbf{- 2 0 0}$ points = veterinary inspection unit will be informed for sure and actions have to be taken (De Jong et al. 2012; Odén 2011). The Decree of Lower Saxony requires the abattoir, according to the German Order on the Protection of Animals and the Keeping of Production Animals (TierSchNutztV), to inform the veterinarian inspection unit if more than $40 \%$ of foot pads were classified in score 1 or more than $20 \%$ of the foot pads were scored equivalent to score 2 (in accordance to Table 5). In consequence of an iterated negative scoring the veterinarian would also lower stocking density (Petermann 2017, Nds. MBI 2014a). 
Table 5: Legal Requirements for the manual foot pad assessment of broiler batches at slaughter house

\begin{tabular}{|l|l|l|l|l|}
\hline & Species & Scale & \multicolumn{1}{|c|}{$\begin{array}{l}\text { Description } \\
\text { (best/worst) }\end{array}$} & Reference \\
\hline $\begin{array}{l}\text { Decree of } \\
\text { Lower } \\
\text { Saxony (DE) }\end{array}$ & $\begin{array}{l}\text { Broiler } \\
\text { (p.m.) }\end{array}$ & $\begin{array}{l}\text { 0-2b } \\
\text { (4-scale) }\end{array}$ & $\begin{array}{l}\text { 0-no lesion } \\
\text { 2b- severe deep } \\
\text { lesion/ ulcer on foot } \\
\text { pad and/ or digit skin }\end{array}$ & Nds. MBI (2014a) \\
\hline $\begin{array}{l}\text { Germany, } \\
\text { Netherlands, } \\
\begin{array}{l}\text { Sweden, } \\
\text { Denmark }\end{array}\end{array}$ & $\begin{array}{l}\text { Broiler } \\
\text { (p.m.) }\end{array}$ & $\begin{array}{l}0-2 \\
\text { 0- no ulcerations } \\
\text { 2- many or severe } \\
\text { ulcerations }\end{array}$ & $\begin{array}{l}\text { TierSchNutztV } \\
\text { (2017); Lund et al. } \\
(2017) \text { and } \\
\text { De Jong et al. } \\
\text { (2012b), ref.to } \\
\text { Ekstrand et al. } \\
(1998)\end{array}$ \\
\hline
\end{tabular}

In Germany, post mortem foot pad assessment is widespread as part of the Health Control Policy for German turkey farmers (Andersson et al. 2015, VDP 2013). The evaluation is based on the scheme of Hocking et al. (2008). A simplified scheme focuses on the worse flocks, when score 0 and 1 are pooled to category A and score 2 and 3 are pooled to category B. Conspicuous flocks with a high prevalence in grade $\mathrm{C}$ are easier to identify, which supports the approach of a continuous improvement of turkey health. Additionally, to a post mortem manual monitoring of foot pad health a camera-based assessment is becoming more common at slaughterhouses. An automatic assessment of foot pad health would fulfill the requirements for an indicator, for example objectivity and validity (Veissier et al. 2013, Louton 2016). Vanderhasselt et al. (2013) could not find major discrepancies between a manual and a camera-based assessment. In contrast, Lund et al. (2017) showed a preference for a better evaluation when foot pad assessment was conducted manually, based on a 3-point scale. The evaluation resulted in a major assessment of the medium score number, compared to a higher percentage of foot pads in score 3 by an automatic system.

\section{Influences on Foot pad health}

Many influences on foot pad health have been proven in studies with chicken and turkeys. Beside biological factors like sex and age, litter quality and several parameters related to birds' bedding and environment were discussed and proved as the major concerns for foot pad lesions. Some of those will be described more detailed. 


\section{Animal-related factors}

Sex: Bergmann et al. (2013) investigated foot pad health of turkeys during rearing. Females were more and earlier susceptible to FPD than male turkeys. However, male poults showed more severe lesions compared to females. Krautwald-Junghanns et al. (2011) proved influences on FPD in a field study in turkey units by means of hens and toms. An overall result of the study were more affected feet in hens compared to toms. Hens at market age showed an FPD prevalence of about $60 \%$ compared to $33.8 \%$ in 16-week old males. That would confirm results from Rudolf (2008) who had more FPD affected female birds than male turkeys in her study. Bergmann et al. (2013) pointed out an increased FPD risk for females (factor 0.76) compared to males. Regarding FPD severity the latter authors carried out a higher prevalence of epithelial necrosis in males (14.6\%) compared to females $(9.3 \%)$ at the end of rearing. Ekstrand and Algers (1997) found no difference of FPD prevalence in broiler males and females. But FPD prevalence in male broilers was significantly higher compared to females after 49 days in an experimental study by Nagaraj et al. (2007).

Age: First macroscopic lesions were described within the first week of life by Mayne et al. (2006), Berk (2009a), Wu and Hocking (2011) and Bergmann et al. (2013). Foot pad dermatitis increases in prevalence and severity with an increasing age (Eichner et al. 2007, Große Liesner 2007, Berk 2009b, Krautwald-Junghanns et al. 2011). Bergmann et al. (2013) pointed out mild hyperkeratosis, high-grade hyperkeratosis with adhesive dirt and epithelial necrosis $(0.1 \%)$ on turkey foot pads at that period. Between $22^{\text {nd }}$ and $35^{\text {th }}$ days of age $30 \%$ of the evaluated foot pad resulted in no lesions, hyperkeratosis was assessed on $15 \%$ of the metatarsal pads, and further $55 \%$ showed severe lesions like high-grade hyperkeratosis, epithelial necrosis and deep lesions. Deterioration was proven with increasing age. Age of the birds must be considered, as younger turkeys gain in size of lesions compared to an increase of depth in older birds (Youssef 2011, Platt 2004). Investigations from Westermaier (2015) in broiler flocks pointed out the monitoring of first lesions after five days post hatch. After 35 of age up to $40 \%$ were scored with minimal surface alterations (Westermaier 2015). 


\section{Environmental factors}

Litter material: Litter texture provokes first lesions like rhagades (Mayne et al. 2007b). The physical structure like hard or soft material as well as the water binding capacity were named as main litter effects on FPD (Youssef et al. 2010). An experimental study with turkey poults led to lowest FPD prevalence on birds kept on lignocellulose compared to wood shavings, chopped straw and dried maize silage (Youssef et al. 2010). Detrimental effects from chopped straw on foot pad lesions in broilers were also pointed out by Berk (2009a). A comparison between long barley straw and wood shavings led to sharply more negative effects on foot pad health in the straw group, independently from dry or wet litter material (Mayne et al. 2007a). Also Kyvsgaard et al. (2013) found better foot pad health in broilers which were kept on wood shavings compared to straw. In a turkey trial, female poults were kept either on lignocellulose or wood shavings during rearing (Berk 2009b). After 7 weeks one group was kept on the old bedding and in the other groups new material like chopped straw or wood shavings were spread. Worse foot pad health resulted from variants with wood shavings during rearing followed by wood shavings or chopped straw during fattening. Applying lignocellulose led to the best metatarsal pads from first day to 16 weeks of age. Those results are similar to Youssef et al. (2010). Turkeys which were kept on wet or dry lignocellulose were least affected in comparison to wood shavings, and FPD was most severe when chopped straw was used as bedding material (Youssef et al. 2010). Ekstrand and Algers (1997) and Rudolf (2008) compared the use of straw and wood shavings and foot pad health was better performed when birds were kept on wood shavings.

Litter depth: Litter depth was pointed out as a risk factor for foot pad dermatitis by Ekstrand et al. (1997). Broilers kept on thin litter from time of chick placement, with less than $5 \mathrm{~cm}$ litter depth, FPD prevalence was lower at time of slaughtering compared to birds which were reared on litter material more than $5 \mathrm{~cm}$ depth at bird's placement. In opposite to that Martrenchar et al. (2002) proved that thin litter layer of wood shaving on concrete floor would pose a risk for FPD in chicken. No distinction was made to litter quality parameters like moisture content. If more than $5 \mathrm{~kg} / \mathrm{m}^{2}$ litter material was added during turkey poult rearing, the risk for FPD increased 
(Martrenchar et al. 2002). In their experimental studies about the influence of litter moisture on FPD Abd El-Wahab et al. (2012) used wood shavings with an amount of $5 \mathrm{~kg} / \mathrm{m}^{2}$ which complied with about $4 \mathrm{~cm}$ litter depth. Because of the higher risk of wet litter in winter month' the overall litter amount seems probably lower during summer month' which was confirmed by Rudolf (2008), who used about $25 \%$ less straw material in an experimental study with turkey hens in summer time compared to the winter cycle.

Litter moisture: Different authors pointed out litter quality, and in particular water content, to be the main reason for foot pad lesions (Martland 1984, Eichner et al. 2007, Mayne et al. 2007a, Wu und Hocking 2011, Youssef et al. 2010, Youssef et al. 2011). Turkeys were kept on clean but wet litter compared to clean and dry litter. After $48 \mathrm{~h}$ macroscopic FPD Score, based on an 8-point scale 0 to 7, was 1.2 in dry (87\% DM) and clean group and 6.2 on metatarsal pads from birds kept on wet (26\% DM) and clean litter material (Mayne et al. 2007a). Histopathological results were similar. An exposure of $8 \mathrm{~h}$ per day over 21 days on artificially made wet litter (27\% DM) showed to be the main reason for FPD in turkeys. Litter moisture influenced the development of FPD more than the sticky and wet feces from a diet with high amounts of soymeal or electrolyte (Youssef et al. 2012b). Abd El-Wahab et al. (2012) also investigated the effect of different exposure times, 4 and $8 \mathrm{~h}$ on varied litter moisture, and FPD increased with litter moisture. Nevertheless, in the study from Youssef et al. (2010) it was not clear whether high foot pad lesions resulted from high litter moisture or extended contact time. De Jong et al. (2014) investigated the influence of wet litter on FPD and other welfare aspects in chickens. The condition of wood shavings (original spread $1 \mathrm{~kg} / \mathrm{m}^{2}$ ) as a litter material was changed by spraying water over the litter and it was classified from two observers from Score 0 (very wet) to Score 10 (completely dry). After 36 days scoring of control groups resulted in 7.8 compared to 3.0 in wet litter group and significantly more severe lesions were found on birds which were kept on wet litter (De Jong et al. 2014). Mayne et al. (2007a) investigated the effect of wet $(26 \% \mathrm{DM})$ and dry (87 \% DM) litter on FPD formation in turkeys. After an exposure of six days, at the age of 34 days, birds showed a macroscopic worse foot pad scoring on wet (6.2) compared to dry (1.8) litter. Furthermore, no difference on FPD 
prevalence was found between contact to a wet and dirty bedding compared to wet and clean litter. The authors assumed that probably water softens and opens the collagen matrix of metatarsal pads' skin (Mayne et al. 2007b, Youssef 2011). That would trigger the immune system. Also bacteria proliferation would be stimulated (Eichner et al. 2007). Moisture content of lignocellulose (16.8\%), chopped straw (31.2\%), wood shavings and dried maize silage (each $24 \%$ ) were investigated in an experimental study with turkeys at $28^{\text {th }}$ day from bird placing (Youssef et al. 2010). Independently from material, FPD score was worse on wet than on dry litter. As a threshold value for minimizing FPD was pointed out a litter moisture content below $30 \%$ during husbandry period (Youssef et al. 2010). Also Abd El-Wahab et al. (2012) derived from their studies a critical moisture content of litter for the onset of FPD at $35 \%$ and Collet (2012) stated $25 \%$ as the optimum litter moisture.

Litter pH: With decreased dry matter content of litter material $(85.5,64.8,65.2,50.1$ and $35.2 \%) \mathrm{pH}$ in litter increased continuously from 6.04 to $6.90,7.24,7.56$ and 8.08 (Abd El-Wahab et al. 2012). Turkeys were fed the same diet so $\mathrm{pH}$ in feces did not differ between groups and it was concluded that litter moisture content influenced litter pH. However, Martland (1985) investigated pH value in wet (29\% DM) and dry (42\% $\mathrm{DM}$ ) litter in a broiler experiment and $\mathrm{pH}$ value was 7.0 to 7.5 for wet and 8.0 to 8.5 for dry litter. It needs to be considered that water was spread over litter in the wet group over one week to induce FPD. In a broiler trial with wood shavings $\mathrm{pH}$ value was 6.3 at day of chick placement and 8.9 after 35 days, associated with $33.3 \%$ litter moisture (Garces et al. 2013).

Wet litter syndrome: The wet litter syndrome describes the consistency of a wet and sticky feces-litter-compound. It includes a reduced dry matter content of litter in consequence of wet excreta, poor drinker management practices as well as compromised ventilation system associated with high litter $\mathrm{pH}$ and high $\mathrm{NH}_{3}$ production (Kamphues 2005, Nagaraj et al. 2007, Dunlop and Stuetz 2016). The increase of water accumulation gains negative effects on environmental conditions like high relative humidity, and pododermatitis and necrotic enteritis (Kamphues 2005, Nagaraj et al. 2007). 
Wet litter often is a subjective classification of a feces-litter-mix. Mayne et al. (2007a) adopted a 5-point scale for litter monitoring from Tucker and Walker (1999): 1=dry, $2=$ slightly damp or tacky, $3=$ damp or tacky with some dry areas in the barn but litter and feces stick to feet, $4=$ litter is mainly wet, sticky or greasy and $5=$ very wet litter and imprint was left when compressed, very slippery. Da Costa et al. (2014) used a 5point scale, from 1 = perfect condition of litter in the whole barn to 2, 3, $4=$ caked litter in $>25,50$ and $>75 \%$ of the house with moderate litter content and finally score $5=$ caked litter $>75 \%$ of the barn with high moisture content. In accordance to Kamphues (2014) the composition of bedding and thus DM of the litter in conventional broiler houses at the end of fattening results mostly from feces $(90 \%)$ and least from litter $(10 \%)$. Therefore, the author pointed out the relevance of water release of feces compared to water release of bedding material. Nevertheless, a comparison between litter material for broilers with sand, wheat straw and sawdust resulted in a strong cake structure in wheat straw (Hafeez et al. 2009). During a six week production period moisture content increased from 13.07 to $46.55 \%$ in sawdust, from 1.75 to $18.89 \%$ and from 6.81 to $41.48 \%$ in sand and wheat straw continuously. Mean absorbing ability was calculated with $246.0,152.0$ and $180.7 \%$ for sawdust, sand and wheat straw. Water holding capacity (WHC) of wood shavings were proved from Villagra et al. (2011). In combination with an apparent density of $0.046 \mathrm{~g} / \mathrm{m}^{3}$ WHC was about $5.395 \mathrm{~cm}^{3} / \mathrm{g}$ wood shavings. Bulk density of wood shavings changed from 77 to $252 \mathrm{~kg} / \mathrm{m}^{3}$ after a 35 day broiler production cycle (Garces et al. 2013). WHC of wood shavings was $2.64 \mathrm{~g} / \mathrm{g}$ litter material, based on DM $(67 \%)$. The water releasing capacity (WRC) after 24 hour decreased from $21.3 \%$ at day 0 to $16.3 \%$ after 35 days (Garces et al. 2013).

Feces is one of the main sources of water addition to litter (Dunlop and Stuetz 2016). Kamphues (2014) described common dry matter content of feces of about 200 g DM $/ \mathrm{kg}$ original substance (OS). In trials from Abd El-Wahab et al. (2013) where the influence from diet on FPD was investigated, DM of feces was between 188 to $209 \mathrm{~g}$ / kg OS. Dunlop et al. (2015) calculated the daily water deposition in a broiler barn through drinking spillage and bird excretion from $0.51 / \mathrm{m}^{2}$ on the $1^{\text {st }}$ day to $3.21 / \mathrm{m}^{2}$ on the $35^{\text {th }}$ day of fattening period. Over 56 days the authors calculated $1041 / \mathrm{m}^{2}$ in total (Dunlop et al. 2015). Stocking density in that trial with commercial breeds was 
17 birds $/ \mathrm{m}^{2}$ and $1 / 3$ of the stock was slaughtered on day 35 . A common and reproducible method to measure dry matter content of litter material is calculating moisture content (\%) by dividing mass of water contained in the litter sample by the mass of the litter (VDLUFA 2014). Dunlop et al. (2015) pointed out an increasing amount of water which is stored in the litter with increased grow-out period of broilers. Reasons could be an accumulation of manure particles which compress the bedding. However, measuring litter moisture by latter described method would probably not consider that effect which is associated with the varied density of different bedding materials (Dunlop et al. 2016; Dunlop and Stuetz 2016). Furthermore, it needs to be considered for airflow management and from physical aspect, that maximum evaporation rate already from dry litter is probably less than the added daily water amount in broiler husbandry systems. That would promote cake formation. Bernhart et al. (2010) explained difficulties when breaking up crusty and sticky litter particles to a friable structure if moisture content was above 20 to $30 \%$, whereby de-caking and tilling might be associated with the release of corrosive gases and moisture (Dunlop et al. 2016).

Ammonia ( $\left.\mathbf{N H}_{3}\right)$ : Ammonia $\left(\mathrm{NH}_{3}\right)$ is discussed to be a suitable indicator for litter quality and ventilation management (Ziegler et al. 2013). $\mathrm{NH}_{3}$ releasing depends on litter moisture and litter pH-value (Elliot and Collins 1982, Weaver and Meijerhof 1991, Nagaraj et al. 2007). If $\mathrm{pH}$ value increases above 7, $\mathrm{NH}_{3}$ volatilization increases due to the shifting from ionized to unionized form (Elliot and Collins 1982). Ziegler et al. (2013) evaluated the influence of climate conditions, particularly $\mathrm{NH}_{3}$, dust, humidity and barn temperature, during rearing on foot pad health. Results of the field study based on the monitoring of 2681 turkeys from 12 farms. The effect from $\mathrm{NH}_{3}$ on foot pad health was significant and FPD increased when $\mathrm{NH}_{3}$ content was above the average of either $0.4 \mathrm{ppm}$ (day 3 to 5) or $12.4 \mathrm{ppm}$ (day 22 to 35). Nevertheless, when turkeys were kept on wet litter (about $27 \%$ DM) no influence on FPD from ammonia but from moisture $(\alpha=0.05)$ was found by Youssef (2011). $\mathrm{NH}_{3}$ rates above $3 \mathrm{~cm}$ from floor were significantly lower for dry litter groups $(85.5 \% \mathrm{DM})$ in comparison to wet litter groups (7.18, 9.13 and $11.0 \mathrm{ppm}$ for 65, 50 and $35 \% \mathrm{DM})$ (Abd El-Wahab et al. 2012). 
Temperature and humidity: The effect of barn temperature within the first three days from turkey poult placing was investigated by Ziegler et al. (2013). An increasing barn temperature and decreasing humidity reduced FPD prevalence. An average outdoor temperature above $10.4{ }^{\circ} \mathrm{C}$ also reduced foot pad lesions. Barn climate with relative humidity of $45 \%$ led to an incidence of FPD on broiler feet of about $13.9 \%$ compared to FPD prevalence after 42 days of $53.5 \%$ under conditions of $75 \%$ relative humidity (Weaver and Meijerhof 1991). Martrenchar et al. (2002) proved a poor fan ventilation, i.e. $<150 \mathrm{~m}^{3} / \mathrm{h} / \mathrm{m}^{2}$, as a significant risk factor for FPD. Turkeys showed less severe lesions during summer time compared to winter months (Rudolf 2008, Da Costa et al. 2014). Based on data from broiler slaughterhouses, Kyvsgaard et al. (2013) pointed out a higher risk for FPD during winter month (October to March), hence season seems to be a risk factor.

\section{Litter amendments}

With the focus on $\mathrm{NH}_{3}$ emissions from poultry units several kinds of litter amendments have been applied in poultry farms and in the US Poultry production in particular ( $\mathrm{Li}$ et al. 2013, Miles et al. 2013). Due to negative impacts of feces-litter mixture, respective ammonia exposure on poultry health, several studies were conducted to investigate potential positive influences of litter amendments on bird's welfare ( $\mathrm{Li}$ et al. 2013, Miles et al. 2013). $\mathrm{NH}_{3}$ is formed through mineralization and microbial decomposition processes of uric acid, whereby uric acid is the main product of the bird's nitrogen metabolism (Li et al. 2013, Donsbough et al. 2010). Outside of the bird's organism the microbial enzyme uricase breaks down uric acid to allantoin, which is converted to urea or glyoxalic acid in the next step of the degradation process (Hafez et al. 2017). And finally, the enzyme urease converts urea into $\mathrm{NH}_{3}$ and $\mathrm{CO}_{2}$ (Kim et al. 2009). The latter step depends on litter $\mathrm{pH}$, litter nitrogen content, litter temperature and moisture ( $\mathrm{Li}$ et al. 2013, Liu et al. 2007, McWard and Taylor 2000). Bacterial decomposition of uric acid increases above litter $\mathrm{pH}$ of 7 and uricase activity is highest at pH of 9 (Blake and Hess 2001). Carr et al. (1990) investigated the relation between litter temperature, litter $\mathrm{pH}$ and $\mathrm{NH}_{3}$ concentration, based on litter ammonium $\left(\mathrm{NH}_{4}\right)$ nitrogen of $1.116 \%$. As a result, the amount of $\mathrm{NH}_{3}$ was reduced below litter $\mathrm{pH}$ of 7.5. Also litter moisture below $30 \%$ had a positive influence on $\mathrm{NH}_{3}$ reduction, 
as well as ventilation rate as an effective management measure (Carr et al. 1990). Litter amendments would act by diminishing the microbial activity in poultry litter and by chemically binding $\mathrm{NH}_{3}$ (McWard and Taylor 2000). Decreasing $\mathrm{NH}_{3}$ concentrations from poultry litter is based on the increase of nitrogen retention as $\mathrm{NH}_{4}{ }^{+}$, which is a non-volatile nitrogen source ( $\mathrm{Li}$ et al. 2013). In order to evaluate the effects of different chemical treatments on $\mathrm{NH}_{3}$ volatilization different studies were performed with sodium bisulfate, acidified clay or aluminum sulfate as $\mathrm{pH}$-reducing litter amendments (Ullman et al. 2004). Those litter amendments are common in the US Poultry production because bedding material remains in the barn up to two years (Rhodes et al. 2011). Thus, turkey poults and day-old broiler chicks are placed on re-used litter (Nagaraj et al. 2007, Wheeler et al. 2008). An overview of studies about sodium bisulfate (SBS) amendments is given in Table 6. The litter application with SBS is also known as 'Poultry Litter Treatment', PLT ${ }^{\circledR}$ (Jones Hamilton 2017). Ullman et al. (2004) described the chemical binding of $\mathrm{NH}_{4}{ }^{+}$by SBS. SBS is a hygroscopic element and as soon as water is absorbed into SBS the chemical compound dissolves into $\mathrm{Na}^{+}$, $\mathrm{H}^{+}$and $\mathrm{SO}_{4}^{-}$(Johnson and Murphy 2008). The released hydrogen ions reduce litter $\mathrm{pH}$ and react with $\mathrm{NH}_{3}$ to form the irreversible component $\mathrm{NH}_{4}{ }^{+}$, which wouldn't release nitrogen (N) when litter pH increases again (Johnson and Murphy 2008, Ullman et al. 2004). 
Table 6: Selected studies about the animal health' and environmental effects of sodium bisulfate litter treatment in broiler flocks

\begin{tabular}{|c|c|c|c|}
\hline Application & $\begin{array}{l}\text { Effects on animal- } \\
\text { based parameters }\end{array}$ & $\begin{array}{c}\text { Effects on environmental } \\
\text { parameters }\end{array}$ & Source \\
\hline $\begin{array}{l}\text { - re-used litter } \\
\text { - } 250 \mathrm{~g} / \mathrm{m}^{2} \mathrm{~d}-1 \\
\text { - pine shavings } \\
\text { - additional water } \\
\text { spreading on litter }\end{array}$ & $\begin{array}{l}\mathrm{n}=2640 \\
\text { - Mort due to ascites: } \\
\text { SBS } 5.9 \% \text { vs. Con } \\
31.5 \% \\
\text { - LW: d } 49 \text { SBS } 2312 \mathrm{~g} \\
\text { vs. Con } 2312 \mathrm{~g}(\mathrm{p}<0.01) \\
\text { - findings in mucosa of } \\
\text { trachea SBS }<\text { Con } \\
(\mathrm{p}<0.001)\end{array}$ & $\begin{array}{l}\text { - Atmospheric } \mathrm{NH}_{3} \text { max. SBS } 22 \\
\text { ppm (d 22) vs. Con } 114.8 \text { ppm } \\
\text { (d } 14 \text { to 22) } \\
\text { - litter moisture: no effect } \\
\text { - litter N: no effect }\end{array}$ & $\begin{array}{l}\text { Terzich et } \\
\text { al. } \\
(1998 a)^{1} \text {; } \\
\text { Terzich et } \\
\text { al. } \\
(1998 b)^{1}\end{array}$ \\
\hline $\begin{array}{l}\text { - re-used litter } \\
\text { - } 457 \mathrm{~g} / \mathrm{m}^{2}(582) \\
\text { - litter sample } 1,9 \mathrm{~cm}\end{array}$ & $\begin{array}{l}\text { Mort: SBS and Con } \\
1.8 \% \\
\text { LW: SBS } 2704 \mathrm{~g} \text { vs Con } \\
2060 \mathrm{~g}(\mathrm{p}<0.05) \\
\text { FPD: no effect }\end{array}$ & $\begin{array}{l}-\mathrm{pH} 6-7 \text { after } 5 \text { to } 7 \mathrm{~d} \\
-\mathrm{pH}>7 \text { after } 27 \mathrm{~d} \\
-\mathrm{NH}_{3}<20 \text { ppm d } 0 \text { to } 30\end{array}$ & $\begin{array}{l}\text { McWard } \\
\text { and } \\
\text { Taylor } \\
(2000)^{1}\end{array}$ \\
\hline $\begin{array}{l}\text { - (new litter for } \\
\text { inoculated chicks) } \\
\text { - pine shavings } \\
\text { - re-used litter (with } \\
\text { pathogen } \\
\text { contaminated feces) } \\
\text { - } 246 \mathrm{~g} / \mathrm{m}^{2} \text { (low) } \\
\text { - } 393 \mathrm{~g} / \mathrm{m}^{2} \text { (high) } \\
\text { - reapplication wk } 5\end{array}$ & $\begin{array}{l}\text { n=375 inoculated group } \\
/ \\
35 \text { uninoculated chicks } \\
\text { - Campylobacter ceca: } \\
6^{\text {th }} \text { wk significant } \\
\text { reduction } \\
\text { - Salmonella: } \text { SBS } \\
\text { (high) significant } \\
\text { reduction in carcass } \\
\text { exterior compared to } \\
\text { Con }\end{array}$ & $\begin{array}{l}\text { - } \mathrm{pH} \text { (low) } 5.2 \text { to } \sim 7.2 \mathrm{~d} 0 \text { to } 42 \\
\text { - } \mathrm{pH} \text { (high) } 3.8 \text { to } \sim 6.9 \mathrm{~d} 0 \text { to } 42 \\
\text { - } \mathrm{pH} \text { Con } 7 \text { to } 7.8 \mathrm{~d} 0 \text { to } 42 \\
\text { - linear increase, no visible effect } \\
\text { of reapplication }\end{array}$ & $\begin{array}{l}\text { Line } \\
(2002)^{1}\end{array}$ \\
\hline $\begin{array}{l}\text { - re-used litter } \\
\text { - pine shavings } \\
\text { - } 390 \mathrm{~g} / \mathrm{m}^{2} \\
\text { - } 488 \mathrm{~g} / \mathrm{m}^{2} \\
\text { - reapplication d } 28 \\
\text { - litter sample } 2 \mathrm{~cm}\end{array}$ & $\begin{array}{l}\mathrm{n}=12 \text { commercial broiler } \\
\text { houses } \\
\text { - Campylobacter feces: } \\
\text { slight delay of onset } \\
\text { after } 6 \mathrm{wk} \\
\text { - Salmonella: no effect } \\
\text { compared to Con after } 6 \\
\text { wk }\end{array}$ & $\begin{array}{l}-\mathrm{pH} \text { SBS } 1.2 / 6.5 / 7.0 \text { at } \mathrm{d} 0 / 14 / \\
42 \\
-\mathrm{pH} \text { Con } 8.5 / 7.8 / 8.0 \text { at } \mathrm{d} 0 / 14 / \\
42\end{array}$ & $\begin{array}{l}\text { Line and } \\
\text { Bailey } \\
(2006)^{2}\end{array}$ \\
\hline $\begin{array}{l}\text { - re-used litter } \\
\text { - pine shavings } \\
(8 \mathrm{~cm}) \\
-220 \mathrm{~g} / \mathrm{m}^{2} \text { (low) } \\
\text { - } 440 \mathrm{~g} / \mathrm{m}^{2} \text { (high) } \\
\text { - plus } 1 \text { trial with } \\
\text { reapplication } \\
(\mathrm{d} 0: 220 \mathrm{~g} \text { and d } 14: \\
\left.220 \mathrm{~g} / \mathrm{m}^{2}\right)\end{array}$ & $\begin{array}{l}\mathrm{N}=960 \\
\text { - Mort wk } 6 \text { between } \\
\text { SBS (low) } 3.9 \% \text { and } \\
\text { Con } 3.03 \% \\
\text { - LW between SBS } \\
\text { (low) } 2310 \mathrm{~g} \text { and Con } \\
2260 \mathrm{~g} \\
\text { - FPD day } 49 \mathrm{SBS} \text { (high } \\
\text { and re-appl.) } 60 \% \text { no } \\
\text { lesions / } 8-10 \% \text { severe } \\
\text { vs. Con } 50 \% \text { no lesions } \\
\text { / } 15 \% \text { severe lesions }\end{array}$ & $\begin{array}{l}\text { - Litter moisture day } 4912-14 \% \\
\text { - } \mathrm{NH}_{3} \text { SBS }<8 \text { ppm until wk } \\
5 / 25 \text { to } 30 \text { ppm until wk } 7 \\
\text { - } \mathrm{NH}_{3} \text { Con }<8 \text { ppm until wk } 3 / 20 \\
\text { to } 28 \text { ppm until wk } 7\end{array}$ & $\begin{array}{l}\text { Nagaraj } \\
\text { et al. } \\
(2007)^{1}\end{array}$ \\
\hline
\end{tabular}




\begin{tabular}{|c|c|c|c|}
\hline \multicolumn{4}{|c|}{$\begin{array}{l}\text { Table 6ff: Selected studies about the animal health' and environmental effects of } \\
\text { sodium bisulfate litter treatment in broiler flocks }\end{array}$} \\
\hline Application & $\begin{array}{l}\text { Effects on animal- } \\
\text { based parameters }\end{array}$ & $\begin{array}{c}\text { Effects on environmental } \\
\text { parameters }\end{array}$ & Source \\
\hline $\begin{array}{l}\text { - new litter } \\
\text { - wheat straw (ws), } \\
\text { wood shavings } \\
\text { (wos); (depth } 5 \mathrm{~cm}) \\
\text { - } 244 \mathrm{~g} / \mathrm{m}^{2}\end{array}$ & $\begin{array}{l}\text { - Mort no effect } \\
\text { - LW day } 39 \text { significant } \\
\text { differences between } \\
\text { bedding material, not } \\
\text { SBS vs. Con }\end{array}$ & $\begin{array}{l}\mathrm{n}=11 / 12 \\
\text { - } \mathrm{NH}_{3} \text { emissions sign. reduced by } \\
\mathrm{SBS} \text { up to wk } 3 \\
\text { - mean of total } \mathrm{NH}_{3} \text { emission no } \\
\text { difference } \mathrm{SBS} \text { to Con } \\
\text { - wos: around waterer plus } 19 \% \\
\text { compared to ws } \\
\text { - wos: waterer } 4.1 \mathrm{compared} \mathrm{to} \\
\text { feeder } 1.98 \mathrm{moles} / \mathrm{m}^{2} \\
\text { - ws: waterer } 3.45 \mathrm{compared} \mathrm{to} \\
\text { feeder } 2.21 \mathrm{moles} / \mathrm{m}^{2} \\
\text { - pH SBS } 8.36 \mathrm{vs} \mathrm{Con} 8.98 \text { at day } \\
39\end{array}$ & $\begin{array}{l}\text { Tasistro } \\
\text { et al. } \\
(2007)^{1}\end{array}$ \\
\hline $\begin{array}{l}\text { - new litter } \\
\text { - wood shavings } \\
\text { - } 183 \mathrm{~g} / \mathrm{m}^{2} \text { (low) } \\
\text { - } 366 \mathrm{~g} / \mathrm{m}^{2} \text { (high) } \\
\text { - from d } 21 \text { to } 56 \\
\text { weekly re- } \\
\text { application } \\
\text {--------- } \\
\text { - re-used litter } \\
\text { - } 244 \mathrm{~g} / \mathrm{m}^{2} \text { and } \\
\text { biweekly at } \mathrm{d} 21,35 \\
\text { and } 49\end{array}$ & $\begin{array}{l}\mathrm{n}=4 \text { flocks } \\
\text { - LW SBS (high/low) } \\
4.02 / 3.99 \text { vs. Con } \\
3.95 \mathrm{~kg} \\
\text { - FPD scale } 0-4 \\
\text { SBS (high/low) } \\
0.67 / 0.67 \text { to Con } 1.33 \text { at } \\
\text { d } 56 \\
------ \\
\text { - Mort SBS } 3.67 \text { vs Con } \\
3.92 \%\end{array}$ & $\begin{array}{l}\text { - } \mathrm{NH}_{3} \mathrm{~d} 56 \mathrm{SBS} \text { (high/low) } 1.12 / 1.31 \text { vs. } \\
\text { Con } 1.82 \% \text { in dry matter } \\
\text {-pH d } 56 \\
\mathrm{SBS} \text { (high/low) } 5.55 \text { /5.95 vs Con } \\
6.88 \\
\text { - dry matter d } 56 \\
\mathrm{SBS} \text { (high/low) } 46.3 \text { / } 45.2 \text { vs. } \\
\text { Con } 41.7 \% \\
\text {--------- } \\
\text { - pH SBS } 7.50 \text { vs Con } 7.65 \\
\text { - dry matter SBS } 68.3 \% \text { vs. Con } \\
68.2 \%\end{array}$ & $\begin{array}{l}\text { Li et al. } \\
(2013)^{1}\end{array}$ \\
\hline $\begin{array}{l}\text { - re-used litter ( } 3 \\
\text { years old) and new } \\
\text { litter } \\
-50 \% \text { peanut hulls } \\
50 \% \text { wood chips } \\
\text { - } 244 \mathrm{~g} / \mathrm{m}^{2} \\
-244 \mathrm{~g} / \mathrm{m}^{2} \text { day }-1, \\
\text { wk } 3 \text { and wk } 5 \\
\text { - litter samples depth } \\
2.5 \mathrm{~cm}\end{array}$ & $\begin{array}{l}\mathrm{n}=6 \text { commercial broiler } \\
\text { flocks } \\
\text { - short-term influence of } \\
\text { SBS reapplication on } \\
\text { E.coli }\end{array}$ & $\begin{array}{l}-\mathrm{NH}_{3} \text { at time } \\
\text { minus } 4 \mathrm{~h} / \mathrm{SBS} \text { appl./plus } 6 \mathrm{~h} \\
\mathrm{SBS} 14 / 9 / 17 \mathrm{vs} \text { Con } \\
13 / 17 / 17 \mathrm{mg} / \mathrm{l} \\
\text { - pH significant reduction by re- } \\
\text { application SBS } \\
\text { - moisture SBS } 34.2 \% \text { vs. Con } \\
21.4 \% \text { after } 6 \text { flocks }\end{array}$ & $\begin{array}{l}\text { Hunolt } \\
(2015)^{2}\end{array}$ \\
\hline
\end{tabular}

${ }^{1}$ experimental study; ${ }^{2}$ field study; SBS- Sodium bisulfate; Con- Control group;

wk-week, Mort-mortality, LW-liveweight, FPD-foot pad dermatitis

Results of the study from McWard and Taylor (2000) showed an effect of reducing litter $\mathrm{pH}$ less than $\mathrm{pH} 7$ lasted about five to seven days after SBS application, compared to the $\mathrm{NH}_{3}$ reduction beneath 20 ppm until 30 days after SBS application. The authors assumed a longer lasting effect from sulfates directly to bacterial enzymatic metabolism regarding their ability to generate $\mathrm{NH}_{3}$. In this study aluminum sulfate and 
SBS had no effect on foot pad health. The one-time SBS application of $250 \mathrm{~g} / \mathrm{m}^{2}$ before chick placing resulted in significant better respiratory parameters like loss of cilia or epithelial cell hypertrophy and necrosis in the mucosa of tracheas compared to control group at $23^{\text {rd }}$ day of life (Terzich et al. 1998a; Terzich et al. 1998b). Atmospheric $\mathrm{NH}_{3}$ was clear reduced but results from that studies also show an $\mathrm{NH}_{3}$ level of about $96 \mathrm{ppm}$ (Con) and $88 \mathrm{ppm}$ (SBS) the day before SBS treatment and chick placing due to re-used litter. Effects from SBS litter amendment on foot pad lesions (Score none/ mild/ severe lesions) were found by Nagaraj et al. (2007). The different SBS amounts of $220 \mathrm{~g} / \mathrm{m}^{2}$ or $440 \mathrm{~g} / \mathrm{m}^{2}$ before chick placing as well as the combination of $220 \mathrm{~g}$ at day 0 and again at day 21 did not lead to clearly better foot pad health. Nevertheless, after 49 days of age $50 \%$ (Con) or $60 \%$ (SBS) of feet were without lesions and from $8 \%$ (group $440 \mathrm{~g} \mathrm{SBS}$ ) to $15 \%$ (Con and $220 \mathrm{~g} \mathrm{SBS}$ ) had severe foot pad lesions. Litter moisture during husbandry period did not exceed $18 \%$ over all groups. In another study with focus on foot pad health differences have been proved between SBS and Con groups (Li et al. 2013). After 56 days birds had an average foot pad score of 0.67 (SBS) compared to 1.33 in Con group on a scale system from Score 0 to 4 . SBS groups differed in application rate, 183 and $366 \mathrm{~g} / \mathrm{m}^{2}$ and at the end of rearing the dry matter content was similar in both SBS groups (high: $46.3 \%$; low $45.2 \%$ ) and compared to Con group with a dry matter content of litter about $41.7 \%$.

Currently, the use of sodium bisulfate as a litter treatment in animal husbandry systems is not explicitly permitted in the European Union. But sodium bisulfate is a legal food additive (EU 231/2012) and furthermore a feed additive (EU 2015/1414) for pets and other animals not destined for consumption (EU 2012, EU 2015). 


\section{References}

Abd El-Wahab, A., Radko, D. and Kamphues, J. (2013): High dietary levels of biotin and zinc to improve health of foot pads in broilers exposed experimentally to litter with critical moisture content. Poultry Sci. 92:1774-1782.

Abd El-Wahab, A., Visscher, C.F., Beineke, A., Beyerbach, M. and Kamphues, J. (2012): Experimental studies on the effects of different litter moisture contents and exposure time to wet litter on development and severity of foot pad dermatitis in young fattening turkeys. Arch. Geflügelk. 76:55-62.

Allain, V., Huonnic, D., Rouina, M. and Michel, V. (2013): Prevalence of skin lesions in turkeys at slaughter. Br. Poultry Sci. 54:33-41.

Andersson, R., Toppel, K. and Heesen, S. (2015): Kann man Tierwohl messen? Erste Erfahrungen mit Tierschutz-/ Tierwohlindikatoren bei Puten. In: K. Damme und F. Muth (ed.): Geflügeljahrbuch 2016. Schwerpunkt Tierwohl. Stuttgart: Eugen Ulmer, 24-32.

Animalia (2014) In Kittelsen, K.E., Granquist, E.G., Kolbjornsen, O., Nafstad, O. and Moe, R.O. (2015): A comparison of post-mortem findings in broilers dead-on-farm and broilers dead-on-arrival at the abattoir. Poultry Sci. 94:2622-2629.

Ask, B. (2010): Genetic variation of contact dermatitis in broilers. Poultry Sci. 89:866875.

BauGB (2017): "Baugesetzbuch in der Fassung der Bekanntmachung vom 3. November 2017 (BGBl. I S. 3634)". Download 12.10.2017

Beaumont, C., Lebihan-Duval, E., Mignon-Grasteau, S. and C. Leterrier (2010): The European experience in poultry welfare-A decade ahead. Poultry Sci. 89:825-831.

Beck, M. (2012): Statistische Angaben zum Eier- und Geflügelmarkt. In: K. Damme and C. Möbius (ed.): Geflügeljahrbuch 2013. Schwerpunkt Tiergesundheit. Stuttgart: Eugen Ulmer, 33-52.

Beck, M. (2017): Statistik und Ökonomie. Die neuesten Zahlen: Der Eier- und Geflügelmarkt. In: Damme, K. Muth, F. and Mayer, A. (ed.): Geflügeljahrbuch 2018. Schwerpunkt Deutschland im internationalen Vergleich. Stuttgart: Eugen Ulmer, 5674.

Berg, C. (2002): Health and Welfare in Organic Poultry Production. Act. Vet. Scandinavia, 43,1:S37. DOI:10.1186/1751-0147-43-S1-S37.

Bergmann, S., Ziegler, N., Bartels, T., Hübel, J., Schumacher, C., Rauch, E., Brandl, S., Bender, A., Casalicchio, G., Krautwald-Junghanns, M.-E. and Erhard, M.H. (2013): Prevalence and severity of foot pad alterations in German turkey poults during the early rearing phase. Poultry Sci. 92:1171-1176.

Berk, J. (2017): Faustzahlen zur Haltung von Mastgeflügel. In. Geflügeljahrbuch 2018. (ed. Damme, K. and Muth, F.). Eugen Ulmer Verlag, Stuttgart. 197-218.

Berk, J. (2009a): Einfluss der Einstreuart auf Prävalenz und Schweregrad von Pododermatitis bei männlichen Broilern. Berl. Munch. Tierarztl. 122:257-263. 
Berk, J. (2009b): Effekte der Einstreuart auf Tiergesundheit und Tierleistungen bei Putenhennen. In: Rahmann, G. and Schumacher, U. (ed.) Neues aus der Ökologischen Tierhaltung. 23-29.

Bernhart, M., Fasina, O.O., Fulton, J. and Wood, C.W. (2010): Compaction of poultry litter. Bioresour. Technol. 101:234-238.

Bessei, W. (2006): Welfare of broilers: a review. World's Poultry Sci. J. 62: 455-466.

Bilgili, S.F., Alley, M.A., Hess, J.B. and Nagaraj, M. (2006): Influence of Age and Sex on Footpad Quality and Yield in Broiler Chickens Reared on Low and High Density Diets. J. Appl. Poultry Res. 15:433-441.

Blake, J.P. and Hess, J.B. (2001): Sodium Bisulfate (PLT) as a Litter Treatment. Alabama Cooperative Extension System, ANR-1208, Alabama A\&M and Auburn Universities.

BML (1999): Bundeseinheitliche Eckwerte für eine freiwillige Vereinbarung zur Haltung von Jungmasthühnern (Broiler, Masthähnchen) und Mastputen. Bundesministerium für Landwirtschaft, Berlin. 23.09.1999.

Bookers, E.A.M. and De Boer, I.J.M. (2009): Economic, ecological, and social performance of conventional and organic broiler production in the Netherlands. Br. Poultry Sci. 50:546-557.

Brambell, F.W.R. (1967): Report of the Technical Committee to Enquire into the Welfare of Animals kept under Intensive Livestock Husbandry Systems. London, England. Reprint http://edepot.wur.nl/134379.

Broom, D.M. (2007): Welfare in relation to feelings, stress and health. Revista electrónica de Vet. 8:1695-7504

Broom, D.M. and Fraser, A.F. (2007): Domestic Animal Behaviour and Welfare. CABI Publishing, $4^{\text {th }}$ edition. Oxfordshire. UK.

Broom, D.M. (1986): Indicators of poor welfare. Br. Vet. J. 142:524-526.

Buda, S., Platt, S. and Budras, K.D. (2002): Sensory nerve endings in the footpads of turkeys. Proceedings of the 4th International Symposium on Turkey Diseases. Berlin. 78-82.

Buijs, S., Keeling, L., Rettenbacher, S., Van Poucke, E. and Tuyttens, F.A.M. (2009): Stocking density effects on broiler welfare. Identifying sensitive ranges for different indicators. Poultry Sci. 24:77-80.

Butterworth, A., De Jong, I.C., Keppler, C., Knierim, U., Stadig, L. and Lambton, S. (2015): What is being measured, and by whom? Facilitation of communication on technical measures amongst competent authorities in the implementation of the European Union Broiler Directive (2007/43/EC). Animal. 1-7.

Butterworth, A. (2013): On-Farm Broiler Welfare Assessment and Associated Training. Braz. J. Poultry Sci. 15:71-78.

Butterworth A. and Haslam S.M. (2009): A Lameness Control Stategy for Broiler Fowl. Welfare Quality Reports No. 13, ISBN 1-902647-97-1 
Candiani, D., Salamano, G., Mellia, E., Doglione, L., Bruno, R., Toussaint, M. and Gruys, E. (2008): A Combination of Behavioral and Physiological Indicators for Assessing Pig Welfare on the Farm. J of Appl Animal Welfare Sci 11:1-13.

Carr, L.E., Wheaton, F.W. and Douglass, L.W. (1990): Empirical models to determine ammonia concentrations from broiler chicken litter. Transactions of the ASAE. $33: 1337-1342$.

Collet, S.R. (2012): Nutrition and wet litter problems in poultry. Anim. Feed Sci. Tech. 173:65-75.

Clark, S. and Bailey, A. (2014): Current health and industry issues facing the turkey industry. Proceedings of 10th Hafez International Symposium on turkey diseases. Berlin. 54-62.

Da Costa, M.J., Grimes, J.L., Oviedo-Rondon, E.O., Barasch, I., Evans, C., Dalmagro, M. and Nixon, J. (2014): Footpad dermatitis severity on turkey flocks and correlations with locomotion, litter conditions, and body weight at market age. J. Appl. Poultry Res. 23:268-279.

Da Costa, M., Grimes, J.L., Oviedo, E., Shah, S., Barasch, I., Evans, C., Black, S., Dalmagro, M. and Nixon, J. (2013): Current Challenges and Opportunities for Turkey Flock Management: Footpad Health and Ventilation. Proceedings of the 7th Hafez International Symposium on Turkey Production. Berlin. 99-105.

Damme, K. (2017): Poultry Business studies. Faustzahlen der Landwirtschaft. In: In: K. Damme, F. Muth and A. Mayer (ed.): Geflügeljahrbuch 2018. Schwerpunkt Deutschland im internationalen Vergleich. Stuttgart: Eugen Ulmer, 84.

Dawkins, M:S., Donelly, S. and Jones, T.A. (2004): Chicken welfare is influenced more by housing conditions than by stocking density. Nature. 427:342-344.

De Gussem, M. (2013): Broiler Signals. A practical Guide. Roodbont, Agricultural Publishers. BC Zutphen. The Nederlands.

Allain, V., Huonnic, D., Rouina, M. and Michel, V. (2013): Prevalence of skin lesions in turkeys at slaughter. Br. Poultry Sci. 54:33-41.

De Jong, I.C., Gunnink, H. and van Harn, J. (2014): Wet litter not only induces footpad dermatitis but also reduces overall welfare, technical performance, and carcass yield in broiler chickens. J. Appl. Poultry Res. 23:51-58.

De Jong, I.C., van Harn, J., Gunnink, H., Hindle, V.A. and Lourens, A. (2012): Footpad dermatitis in Dutch broiler flocks: Prevalence and factors of influence. Poultry Sci. 91:1569-1574.

De Jong, I.C., van Harn, J., Gunnink, H., Lourens, A. and van Riel, J.W. (2012b): Measuring foot-pad lesions in commercial broiler houses. Some aspects of methodology. Anim. Welfare 21:325-330.

Destatis (2017): Tiere und tierische Erzeugung. Landwirtschaftliche Betriebe mit Haltungen von Geflügel und Geflügelbestand. Statistisches Bundesamt, https://www.destatis.de/DE/ZahlenFakten/Wirtschaftsbereiche/LandForstwirtschaftF ischerei/TiereundtierischeErzeugung/Tabellen/BetriebeGefluegelBestand.html.

Download am 29.10.2017 
Donsbough, A.L., Powell, S., Waguespack, A., Bidner, T.D. and Southern, L.L. (2010): Uric acid, urea, and ammonia concentrations in serum and uric acid concentration in excreta as indicators of amino acid utilization in diets for broilers. Poultry Sci. 89:287-294.

Dunlop, M.W., Blackall, P.J. and Stuetz, R.M. (2015): Water addition, evaporation and water holding capacity of poultry litter. Sci. tot. environm. 538:979-985.

Dunlop, M.W. and Stuetz R.M. (2016): Wet litter - factors associated with the shed micro-environment and litter properties. 27th Annual Australian Poultry Science Symposium, 14-17 February 2016, Sydney, NSW, Australia.

Dunlop, M.W., Moss, A.F., Groves, P.J., Wilkinson, S.J., Stuetz, R.M. and Selle, P.H. (2016): The multidimensional causal factors of 'wet litter' in chicken-meat production. Sci. Total Environ. 562:766-776.

DVFA (2017): Ministry of Environment and Food of Denmark. FPD Control of Broilers.

https://www.foedevarestyrelsen.dk/english/Animal/AnimalWelfare/Farm_animals/Br oilers/Pages/default.aspx; Download 12.12.2017

Edtmayr, T., Sunk, A. and Sihn, W. (2016): An Approach to integrate Parameters ans Indicators of Sustainability Management into Valua Stream Mapping. 48th CIRP Conference on Manufacturing Systems - CIRP CMS 2015 41: 289-294.

Eichner, G., Vieira, S.L., Torres, C.A., Coneglian, J.L.B., Freitas, D.M. and Oyarzabal, O.A. (2007): Litter moisture and Footpad Dermatitis as affected by diets formulated on an all-Vegetable Basis or Having the Inclusion of Poultry By-Product. J. Appl. Poultry Res. 16: 344-350.

Ekstrand, .C., Carpenter, E., Andersson, I. and Algers, B. (1998): Prevalence and control of foot pad dermatitis in broilers in Sweden, Br. Poultry Sci. 39:318-324.

Ekstrand, C. and Algers, B. (1997): The effect of litter moisture of the development of foot-pad dermatitis in broilers. Proceedings of the Society of Veterinary Epidemiology and Preventive Medicine. Chester, UK. 144-152.

Ekstrand, C., Algers, B. and Svedberg, J. (1997): Rearing conditions and foot-pad dermatitis in Swedish broiler chickens. Prev. Vet. Med. 31:167-174.

Elliot, H.A. and Collins, N.E. (1982): Factors affecting ammonia release in broiler litter. Trans ASAE. 25:413-424.

Erasmus, M.A. (2017): A review of the effects of stocking density on turkey behaviour, welfare, and productivity. Poultry Sci., 96:2540-2545.

Estevez, I. (2007): Density allowances for broilers: where to set the limits? Poultry Sci. 86:1265-1272.

European Union (2002): Recommendation concerning' turkeys (Meleagris gallopavo spp.) https://www.coe.int/t/e/legal_affairs/legal_co-

operation/biological_safety_and_use_of_animals/farming/Rec\%20Turkeys.asp.

Download 12.12.2018.

European Union (2007): Directive 2007/43/EC - minimum rules for the protection of chickens kept for meat production. https://eur-lex.europa.eu/legal- 
content/EN/TXT/PDF/?uri=CELEX:32007L0043\&from=EN.

Download 10.12.2017.

European Union (2012): Directive 231/2012 - Specifications for food additives listed in annex II and III to Regulation (EC) No 1333/2008 of the European Parliament and of the Council. https://eur-lex.europa.eu/legal-

content/EN/TXT/PDF/?uri=CELEX:02012R0231-20200702\&from=EN.

Download 10.12.2017

European Union (2015): COMMISSION IMPLEMENTING REGULATION (EU) 2015/1414 of 20 August 2015 amending Implementing Regulation (EU) No 136/2012 concerning the authorisation of sodium bisulphate as feed additive for pets and for non-food producing animals. https://eur-lex.europa.eu/legalcontent/EN/TXT/PDF/?uri=CELEX:32015R1414\&from=EN. Download 15.12.2018.

Evans, R.D., Edson, R.K., Watkins, K.L., Robertson, J.L., Meldrum, J.B. and Novilla, M.N. (2000): Turkey knockdown in successive flocks. Avian Dis. 44:730-736.

FAWC (Farm Animal Welfare Council) (2009): Farm Animal Welfare in Great Britain: Past, Present and Future. http://www.fao.org/fileadmin/user_upload/ animalwelfare/ppf-report091012.pdf. Download 31.10.2017.

Fraser, D. (2008): Understanding animal welfare. Acta Vet. Scand. 50(1), S1.

Garces, A., Afonso, S.M.S., Chilundo, A. and Jairoce, C.T.S. (2013): Evaluation of different litter materials for broiler production in a hot and humid environment: 1. Litter characteristics and quality. J. Appl. Poultry Res. 22:168-176.

GeflPestSchV (2016): Verordnung zum Schutz gegen die Geflügelpest. "GeflügelpestVerordnung in der Fassung der Bekanntmachung vom 8. Mai 2013 (BGBl. I S. 1212), die zuletzt durch Artikel 1 der Verordnung vom 29. Juni 2016 (BGB1. I S. 1564) geändert worden ist". Download 26.3.2018.

Glatz, P. and Rodda, B. (2013): Turkey farming: Welfare and husbandry issues. African J. Agr. Res. 8:6149-6163.

Greene, J. A., McCracken, R. M., Evans, R. T. (1985). A contact dermatitis of broilersclinical and pathological findings. Avian Pathol. 14:23-38.

Große Liesner, B. (2007): Vergleichende Untersuchungen zur Mast- und Schlachtleistung sowie zum Auftreten (Häufigkeit/Intensität) primär nicht-infektiöser Gesundheitsstörungen bei Puten fünf verschiedener Linien. Dissertation, Tierärztliche Hochschule Hannover.

Guardia, S., Konsak, B., Combes, S., Levenez, F., Cauquil, L., Guillot, J.-F., MoreauVauzelle, C., Lessire, M., Juin, H. and Gabriel, I. (2011): Effects of stocking desnity on the growth performance and digestive microbiota of broiler chickens. Poultry Sci. 90:1878-1889.

Hafeez, A., Suhail, S.M., Durrani, F.R., Da Wood Jan, Ahmad, I. Chand, N., et al. (2009): Effect of different types of locally available litter materials on the performance of broiler chicks. Sarhad J. Agric. 25:581-586. 
Hafez, R.M., Abdel-Rahman, T.M. and Naguib, R.M. (2017): Uric acid in plants and microorganisms: Biological applications and genetics - A review. J of Advanced Res $8: 475-486$.

Hafez, H.M. (2006): Genetic selection of turkey and health related problems. Proceedings of 6th International Symposium on Turkey Diseases, Berlin, 5-16.

Hocking, P.M., Harkness, A., Veldkamp, T. and Vinco, L.J. (2017): Do foot pad scores measure turkey welfare? Proceedings of the 11th Turkey Science and Production Conference. Chester, UK, 20-23.

Hocking, P.M. and Wu, K. (2013): Traditional and commercial turkeys show similar susceptibility to foot pad dermatitis and behavioral evidence of pain. Brit. Poultry Sci. 54:281-288.

Hocking, P.M., Mayne, R.K., Else, R.W., French, N.A. and Gatcliffe, J. (2008): Standard European footpad dermatitis scoring system for use in turkey processing plants. World's Poultry Sci. J. 64:323-328.

Hunolt, A.E. (2015): Reducing Ammonia Volatilization and Escherichia coli from Broiler Litter Using Multiple Applications of Sodium Bisulfate. Dissertation. Virginia Polytechnic Institute and State University, VA, USA.

Johnson, T.M. and Murphy, B. (2008): Use of Sodium Bisulfate to Reduce Ammonia Emissions from Poultry and Livestock Housing. In: Muhlbauer, E., Moody, L., Burns, R. (Ed.) "Mitigating Air Emissions from Animal Feeding Operations Conference Proceedings", 74-78, Armes: Iowa State University.

Jones-Hamilton AG (2017): Product Data Sheet for Broilers - Poultry Litter Treatment. https://joneshamiltonag.com

Julian, R.J. (2004): Production and growth related disorders and other metabolic diseases of poultry - A review. The Vet. J. 169:350-369.

Kamphues, J. (2014). Zur Bedeutung von Fütterung und Haltung für die Fußballengesundheit beim Mastgeflügel. Amtstierärztlicher Dienst und Lebensmittelkontrolle 3, 1-13.

Kamphues, J. (2005): Wet Litter Syndrome. In: O. Siegmann und U. Neumann (Hg.): Kompendium der Geflügelkrankheiten. 6. Aufl. 1 Band. Hannover: Schlütersche Verlagsgesellschaft mbH \& Co. KG, 326-327.

Kim, W.K., Weeks, L.J., Anderson, R.C., Nisbet, D.J., Dunkley, K. and Ricke, S.C. (2009): Effects of nitrocompounds on uric acid-utilizing microorganisms, nitrogen retention, and microbial community in laying hen manure. J. of Environ. Sci. and Health Part B. 44:403-406.

Knierim, U., Andersson, R., Keppler, C., Petermann, S., Rauch, E., Spindler, B. and Zapf, R. (2016): Tierschutzindikatoren: Leitfaden für die Praxis - Geflügel. Darmstadt: Kuratorium für Technik und Bauwesen in der Landwirtschaft (KTBL).

Knierim, U. (2001): Grundsätzliche ethologische Überlegungen zur Beurteilung der Tiergerechtheit bei Nutztieren. Dtsch Tierärztl Wochenschr 190:261-266. 
Krautwald-Junghanns, M.E., Ellerich, R., Mitterer-Istyagin, H., Ludewig, M., Fehlhaber, K., Schuster, E., Berk, J., Petermann, S. and Bartels, T. (2011): Examinations on the prevalence of footpad lesions and breast skin lesions in British United Turkeys Big 6 fattening turkeys in Germany. Part I: prevalence of footpad lesions. Poultry Sci. 90:555-560.

Krautwald-Junghanns, M.-E., Ellerich, R., Böhme, J., Cramer, K., DellaVolpe, A., Mitterer-Istyagin, H., Ludewig, M., Fehlhaber, K., Schuster, E., Berk, J., Aldehoff. D.; Fulhorst, D., Kruse, W., Dressel, A., Noack, U. and Bartels, T. (2009): Erhebung zur Haltung und Gesundheit bei Mastputen in Deutschland. Berl. Munch. Tierarztl. 122:271-283.

Kulke, K., Habig, C., Kemper, N. and Spindler, B. (2014): Untersuchungen zum Vorkommen von Kannibalismus bei nicht schnabelgekürzten Putenhähnen bei unterschiedlichen Besatzdichten. Abschlussbericht ML Niedersachsen. $\mathrm{https}: / / \mathrm{www}$.google.com/url? $\mathrm{sa}=\mathrm{t} \& \mathrm{rct}=\mathrm{j} \& \mathrm{q}=\& \mathrm{esrc}=\mathrm{s} \&$ source $=\mathrm{web} \& \mathrm{~cd}=\& \mathrm{ved}=2 \mathrm{ahU}$ KEwjP4NjSkIbrAhUQCwKHd54Bx8QFjABegQIBhAB\&url=https\%3A\%2F\%2Fwww.ml.niedersachsen.de \%2Fdownload\%2F94265\%2FAbschlussbericht_Besatzdichte_Puten_Ruthe.pdf\&usg $=$ AOvVaw03IZuurB0s_nB4iKuS9hU. Download vom 10.12.2018.

Kyvsgaard, N.C., Jensen, H. B., Ambrosen, T. and Toft, N. (2013): Temporal changes and risk factors for foot-pad dermatitis in Danish broilers. Poultry Sci. 92:26-32.

Li, H., Lin, C., Collier, S., Brown, W. and White-Hansen, S. (2013): Assessment of frequent litter amendment application on ammonia emission from broiler operations. J. Air Waste Manag. 63:442-452.

Lichter, J. and Kleibrink, J. (2016): Geflügelwirtschaft weltweit - Deutschland im internationalen Vergleich Eine Analyse der Erzeugungsstandards. Eine Analyse der Erzeugungsstandards. Hg. v. Handelsblatt Research Institute. Düsseldorf. Online verfügbar unter http://www.zdgonline.de/uploads/tx_userzdgdocs/Studie_Gefluegelwirtschaft_weltweit.pdf, zuletzt geprüft am 23.10.2019.

Line, J.E. (2002): Campylobacter and Salmonella Populations Associated with Chickens Raised on Acidified Litter- Poultry Sci. 81:1473-1477.

Line, J.E. and Bailey, J.S. (2006): Effect of On-Farm Litter Acidification Treatments on Campylobacter and Salmonella Populations in Commercial Broiler Houses in Northeast Georgia. Poultry Sci. 85:1529-1534.

Liu, Z., L. Wang, D. Beasley and E. Oviedo. 2007. Effect of moisture content on ammonia emissions from broiler litter: A laboratory study. J. Atm. Chem. 58:41-53.

Lorz, A. and Metzger, E. (2008): Tierschutzgesetz - Kommentar. 6. Aufl., München: C.H. Beck. § 1 TierSchG. Zweck und Grundsatz des Gesetzes, Schmerzen, Leiden oder Schäden.

Lorz, A. and Metzger, E. (2019): Tierschutzgesetz - Kommentar. 7. Aufl., München: C.H. Beck. § 11 TierSchG, Betriebliche Eigenkontrollen, 281. 
Louton, H. (2016): Interview mit einem Schlachthofbetreiber. In: Internationale Gesellschaft für Nutztierhaltung - IGN (Hrsg.) Nutztierhaltung im Fokus. Tierschutzindikatoren am Schlachthof. München, 49-50.

Lund, V. P., Nielsen, L. R., Oliveira, A.R.S., Christensen, J. P. (2017). Evaluation of the Danish footpad lesion surveillance in conventional and organic broilers: Misclassification of scoring. Poultry Sci. 96:2018-2028.

Martland, M.F. (1984): Wet litter as a cause of plantar pododermatitis, leading to foot ulceration and lameness in fattening turkeys. Avian Pathol. 13:241-252.

Martland, M.F. (1985): Ulcerative dermatitis in broiler chickens: The effects of wet litter, Avian Pathol. 14:353-364.

Martrenchar. A., Boilletot, E., Huonnic, D. and Pol, F. (2002): Risk factors for footpad dermatitis in chicken and turkey broilers in France. Prev. Vet. Med. 52:213-226.

Mayne, R.K., Else, R.W. and Hocking, P.M. (2007a): High litter moisture alone is sufficient to cause footpad dermatitis in growing turkeys. Br. Poultry Sci. 48:538-545.

Mayne, R.K., Else, R.W. and Hocking, P.M. (2007b): High dietary concentrations of biotin did not prevent foot pad dermatitis in growing turkeys and external scores were poor indicators of histopathological lesions. Br. Poultry Sci. 48:291-298.

Mayne, R.K., Hocking, P.M., Else, R.W. (2006): Footpad dermatitis develops at an early age in commercial turkeys. British Poultry Sci. 47:36-42.

Mayne, R.K. (2005): A review of the aetiology and possible causative factors of foot pad dermatitis in growing turkeys and broilers. World. Poultry Sci. 61:256-267.

McWard, G.W. and Taylor, D.R. (2000): Acidified Clay Litter Amendment. J. Appl. Poultry Res. 9:518-529.

Meluzzi, A., Fabbri, C., Folegatti, E., and Sirri, F. (2008): Survey of chicken rearing conditions in Italy: effects of litter quality and stocking density on productivity, foot dermatitis and carcase injuries. Brit. Poultry Sci. 49:257-264.

Meyer, H. (2015): Welfare: Health Control Plan as part of the guidelines of the voluntary agreement for commercial turkeys in Germany. In: H. M. Hafez (ed.): Turkey Production and Health: Current and future perspectives. Proceedings of the 8th 'Hafez' International Symposium on turkey production. Berlin: Mensch und Buch Verlag, 28-29.

Merskey, H. and Bogduk, N. (1994): Classification of Chronic Pain: Descriptions of Chronic Pain Syndromes and Definitions of Pain Terms. 2. Aufl., Michigan: IASP Press.

Michel, V., Prampart, E., Mirabito, L., Allain, V., Arnould, C., Huonnic, D., Le Bouquin, S. and Albaric, O. (2012): Histologically-validated footpad dermatitis scoring system for use in chicken processing plants. Brit. Poultry Sci. 53:275-281.

Miles, D.M., Brooks, J.P., McLaughlin, M.R. and Rowe, D.E. (2013): Broiler litter ammonia emissions near sidewalls, feeders, and waterers. Poultry Sci. 92:1693-1698.

ML, Niedersächsische Ministerium für Ernährung, Landwirtschaft und Verbraucherschutz (2011): Tierschutzplan Niedersachsen. 
http://www.ml.niedersachsen.de/themen/tiergesundheit_tierschutz/tierschutz/tierschu tzplan_niedersachsen/puten-110863.html. Download 7.09.2017.

Mondon, M., Thöne-Reinke, C. and Merle, R. (2017): Tierwohl und Wohlbefinden Definition, Bewertung und Diskussion mit Fokussierung auf die Milchkuh. Berl. Munch. Tierarztl. DOI: 10.2376/0005-9366-16080.

Nagaraj, M., Wilson, C.A.P., Saenmahayak, B., Hess, J.B. and Bilgili, S.F. (2007): Efficacy of a Litter Amendment to Reduce Pododermatitis in Broiler Chickens. J. Appl. Poultry Res. 16:255-261.

Nds. MBI (2014a): Ausführungsbestimmungen zur Umsetzung von $\S 20$ Abs. 4 und 5 TierSchNutztV - Halten von Masthühnern - RdErl. d. ML v. 11. 12. 2014 - 204.142503/2-828

http://www.voris.niedersachsen.de/jportal/portal/t/zts/page/bsvorisprod.psml;jsession id=49AE81CB35EDD94237CB26459273F0EE.jp15?pid=Dokumentanzeige\&showd occase $=1 \&$ js $\_$peid $=$Trefferliste $\&$ documentnumber $=1 \&$ numberofresults $=1 \&$ fromdoct odoc=yes\&doc.id=VVND-VVND000041583\#focuspoint. Download 10.12.2019.

Nds. MBI (2014b): Mindestanforderungen an die Haltung von Puten. RdErl. d. ML v. 4. 12. 2014 - 204.1-42500/0-396 - Mit Änderung der Gültigkeit bis 31.12.2021. http://www.nds-voris.de/jportal/?quelle=jlink\&query=VVND-785300-ML20141204-01-SF\&psml=bsvorisprod.psml\&max=true. Download vom 10.12.2019.

Nds. MBI (2018): Stallstrukturierung und Beschäftigung von Masthühnern. RdErl. d. ML v. 21. 3. 2018 - 204.1-42503/2-999 (E) - http://www.ndsvoris.de/jportal/?quelle=jlink\&query=VVND-785300-ML-20180321-

SF\&psml=bsvorisprod.psml\&max=true. Download vom 10.12.2019.

Nickel, R., Schlummer, A. and Seiferle, E. (2004): Lehrbuch der Anatomie der Haustiere - Anatomie der Vögel: Haut und Hautgebilde. 2. Aufl., Stuttgart: Parey Verlag.

Odén, K. (2011): Broilers: Data collection in Swedish slaughterhouses. Swedish Board of Agriculture.

https://ec.europa.eu/food/sites/food/files/animals/docs/aw_arch_pres_102011_broiler s_sweden_en.pdf. Download 12.12.2017.

OIE (2011): World Organisation for Animal Health. http://www.oie.int/animalwelfare/developments-in-animal-welfare/ Download 2.09.2017

Part, C.E., Edwards, P., Hajat, S. and Collins, L.M. (2016): Prevalence rates of health and welfare conditions in broiler chickens change with weather in a temperate climate. R. Soc. open sci.3:160197.

Pedersen, M.A., Thamsborg, S.M., Fisker, C., Ranvig, H. and Christensen, J.P. (2003): New production systems: Evaluation of organic broiler production in Denmark. J. Appl. Poultry Res., 12:493-508.

Petermann, S., Moors, E., Baumgarte, J. and Sürie, C. (2017). Tierschutzplan Niedersachsen-Arbeitsergebnisse Nutzgeflügel. Berl. Munch. Tierarztl. 130:185-196. 
Platt, S.L. (2004): Die reticulate scales an den Fußballen schwerer Mastputen und deren Beeinflussung durch unterschiedliche Biotindosierungen unter Feldbedingungen. Dissertation, Freie Universität Berlin.

Puppe, B. (2016): Was ist Tierwohl? ... aus Sicht der Nutztierethologie. http://www.agrarforschung.de/fileadmin/download/2016/Puppe_sek1.pdf. Download 02.11.2017.

Rautenschlein, S. and Ryll, M. (2014): Erkrankungen des Nutzgeflügels: Ursachen, Klinik, Pathologie, Diagnosen, Prophylaxe und Bekämpfung. UTB GmbH, Stuttgart.

Rhodes, J.L., Timmons, J., Nottingham, J.R. and Musser, W. (2011): Broiler Production Management for Potential and Existing Growers. University of Maryland, https://extension.umd.edu/sites/default/files/_docs/POULTRY_BroilerProductionMa nagement_final1.pdf

Rudolf, M. (2008): Einfluss von Besatzdichte und Einstreumaterial auf die Pododermatitis bei Mastputen. Dissertation, Freie Universität Berlin.

Salomon, F.-V. (1993): Lehrbuch der Geflügelanatomie. Gustav Fischer Verlag. Jena. Stuttgart.

Schmitz-Dumont, M. and König, H. (2014): Statistik und Kennzahlen. In: Damme, K. and Muth, F. (ed.) Geflügeljahrbuch 2017. Eugen Ulmer KG, Stuttgart.

Spindler B (2007): Pathologisch-anatomische und histologische Untersuchungen an Gelenken und Fußballen bei Puten der Linie B.U.T. Big 6 bei der Haltung mit und ohne Außenklimabereich. Dissertation, Tierärztliche Hochschule Hannover.

Strüve, H., Toppel, K., Andersson, R., Kaufmann, F. and Recke, G. (2017): Wandel der nordwestdeutschen Putenhaltungen durch mehr Tierwohl: Ergebnisse einer Expertenbefragung. Journal of Socio-Economics in Agriculture 10:1-12.

Tasistro, A.S., Ritz, C.W. and Kissel, D.E. (2007): Ammonia emissions from broiler litter: response to bedding materials and acidifiers. Br. Poultry Sci. 48:399-405.

Terzich, M., Quarles, C., Goodwin, M.A. and Brown, J. (1998a): Effect of Poultry Litter Treatment ${ }^{\mathbb{B}}\left(\mathrm{PLT}^{\mathbb{B}}\right)$ on Death Due to Ascites in Broilers. Avian Dis. 42:385-387.

Terzich, M., Quarles, C., Goodwin, M.A. and Brown, J. (1998b): Effect of Poultry Litter Treatment ${ }^{\circledR}\left(\mathrm{PLT}^{\circledR}\right)$ on the development of respiratory tract lesions in broilers. Avian Pathol. 27:566-569.

TierSchG (2017). "Tierschutzgesetz in der Fassung der Bekanntmachung vom 18. Mai 2006 (BGBl. I S. 1206, 1313), das zuletzt durch Artikel 141 des Gesetzes vom 29. März 2017 (BGBl. I S. 626) geändert worden ist". Download 17.01.2018.

TierSchNutztV (2017). "Tierschutz-Nutztierhaltungsverordnung in der Fassung der Bekanntmachung vom 22. August 2006 (BGBl. I S. 2043), die durch Artikel 3 Absatz 2 des Gesetzes vom 30. Juni 2017 (BGBl. I S. 2147) geändert worden ist". Download 17.01.2018.

Toppel, K., Strüve, H., Recke, G., Kaufmann, F. and Andersson, R. (2016): Influence of 'Legal Frameworks' on turkey husbandry in North-West Germany. Proceedings of 11th "Hafez" International Symposium on Turkey Diseases. Berlin. 27-36. 
Toppel, K., Kaufmann, F. and Andersson, R. (2013): The New German Backbone of Animal Protection in Turkey Production: Health Monitoring or Health Controlling? Proceedings of 7th "Hafez" International Symposium of Turkey Production, Berlin, 69-71.

Tschanz, B. Fölsch, D. W., Graf, B., Grauvogel, A., Loeffler, K., Marx, D., Schmitzer, U., Unshelm, J., Voetz, N. and Zeeb, K. (1987): Bedarfsdeckung und Schadensvermeidung. Deutsche Veterinärmedizinische Gesellschaft (DVG). Gießen.

Tucker, S.A. and Walker, A.W. (1999): Hock burn in Broilers. In Mayne, R.K. (2005): A review of the aetiology and possible causative factors of foot pad dermatitis in growing turkeys and broilers. World's Poult. Sci. J. 61:256-267.

Ullman, J.L., Mukhtar, S., Lacey, R.E. and Carey, J.B. (2004): A Review of Literature Concerning Odors, Ammonia, and Dust from Broiler Production Facilities: 4. Remedial Management Practices. J. Appl. Poult. Res. 13:521-531.

Vanderhasselt, R. F., Sprenger, M., Duchateau, L. and Tuyttens, F.A.M. (2013): Automated assessment of footpad dermatitis in broiler chickens at the slaughter-line: Evaluation and correspondence with human expert scores. Poultry Sci. 92:12-18.

Van Horne; P. and Achterbosch, T. (2008): Animal welfare in poultry production systems: Impact of EU standards on world trade. World's Poult Sci. J. 64:40-52.

VDLUFA (2014): Bestimmung der Trockenmasse. In: VDLUFA (Hg.): Methodenbuch II.2. Die Untersuchung von Sekundärrohstoffdüngern, Kultursubstraten und Bodenhilfsstoffen. 1. Aufl. mit 2. Erg. Darmstadt: VDLUFAVerl. (Handbuch der landwirtschaftlichen Versuchs- und Untersuchungsmethodik, (Methodenbuch) / im Auftr. des Verbandes Deutscher Landwirtschaftlicher Untersuchungs- und Forschungsanstalten hrsg. von Rolf Bassler ; Bd. 2,2).

VDP (2013): Verband Deutscher Putenerzeuger. Bundeseinheitliche Eckwerte für eine freiwillige Vereinbarung zur Haltung von Mastputen. Berlin.

Veauthier, A. and Windhorst, H.-W. (2013): Organisationsformen in der Erzeugung tierischer Nahrungsmittel -Eine vergleichende Analyse zwischen Niedersachsen und seinen bedeutendsten nationalen und internationalen Wettbewerbern -. ISPA Weiße Reihe 31. Vechta.

Veissier, I., Winckler, C., Velarde, A., Butterworth, A., Dalmau, A. and Keeling, L. J. (2013): Development of welfare measures and protocols for the collection of data on farms or at slaughter. In: H. Blokhuis, M. Miele, I. Veissier and B. Jones (ed.): Improving farm animal welfare. Wageningen: Wageningen Academic Publishers.

Veissier, I., Butterworth, A, Bock, B. and Roe, E. (2008): European approaches to ensure good animal welfare. Appl. Anim. Behav. Sci. 113:279-297.

Villagra, A., Olivas, I., Benitez, V. and Lainez, M. (2011): Evaluation of sludge from paper recycling as bedding material for broilers. Poultry Sci. 90:953-957.

Vollmerhaus, B. and Sinowatz, F. (2004): Haut und Hautgebilde. In: Nickel, R., Schummer, A., Seiferle, E. (ed.): Lehrbuch der Anatomie der Haustiere. Band 5 Anatomie der Vögel. Parey Verlag, Stuttgart.

WBA (2015): Wissenschaftlicher Beirat Agrarpolitik beim BMEL. Wege zu einer gesellschaftlich akzeptierten Nutztierhaltung. Gutachten. Berlin. 
Weaver, W.D. Jr. and Meijerhof, R. (1991): The effect of different levels of relative humidity and air movement on litter conditions, ammonia levels, growth, and carcass quality for broiler chickens. Poultry Sci. 70:746-755.

Westermaier, C. (2015): Vergleichende Untersuchungen zur Tiergesundheit von konventionell gehaltenen Ross 308 und Cobb Sasso Masthühnern mit einem neuen Aufzuchtkonzept im Rahmen der konzeptionellen Ausarbeitung von Richtlinien für eine tiergerechtere Masthühnerhaltung. Dissertation, LMU München.

Welfare Quality ${ }^{\circledR}$ 2009: Welfare Quality assessment protocol for poultry (broiler, laying hens). Welfare Quality ${ }^{\odot}$ consortium. Lelystad, Netherlands.

Wheeler, E., K. Casey, R. Gates, H. Xin, Y. Liang and Topper, P. (2008): Litter Management Strategies in Relation to Ammonia Emissions from Floor-Raised Birds. In: Muhlbauer, E., L. Moody and R. Burns, (Ed.) Mitigating Air Emissions from Animal Feeding Operations Conference Proceedings. Iowa State University. 99-103.

Wojcinski, H.S. (2014): Management and Multiple Disease Challenges: When Worlds Collide. Proceedings of the 8th Turkey Science and Production Conference. Chester, UK, 19-21.

Wu, K. and Hocking, P. M. (2011). Turkeys are equally susceptible to foot pad dermatitis from 1 to 10 weeks of age and foot pad scores were minimized when litter moisture was less than 30\%. Poultry Sci. 90:1170-1178.

Yassin, H., Velthuis, A.G.J., Boerjan, M. and Riel, J. (2009): Field study on broilers' first-week mortality. Poultry Sci. 88(4):798-804.

Youssef, I.M.I., Beineke, A., Rohn, K., and Kamphues, J. (2012): Influences of increased levels of biotin, zinc or mannanoligosaccharides in the diet on foot pad dermatitis in growing turkeys housed on dry and wet litter. J. Anim. Physiol. Anim. Nutr. 9:747-761.

Youssef, I.M.I., Beineke, A., Rohn, K. and Kamphues, J. (2012b): Effects of high dietary levels of soybean meal and its constituents (potassium, oligosaccharides) on foot pad dermatitis in growing turkeys housed on dry and wet litter. Arch. Anim. Nutr. 65(2):148-162.

Youssef, I.M.I. (2011): Experimental studies on effects of diet composition and litter quality on development and severity of foot pad dermatitis in growing turkeys. Dissertation. University of Veterinary Medicine Hanover.

Youssef, I.M.I., Beineke, A., Rohn, K. and Kamphues, J. (2011): Effects of litter quality (moisture, ammonia, uric acid) on development and severity of foot pad dermatitis in growing turkeys. Avian Dis. 55:51-58.

Youssef, I.M.I., Beineke, A. and Kamphues, J. (2010): Influence of litter material and its quality on foot pad dermatitis in growing turkeys. Proceedings of the 8th International Symposium on Turkey Diseases. Berlin.

Ziegler, N., Bergmann, S., Hübel, J., Bartels, T., Schumacher, C., Bender, A., Casalicchio, G., Küchenhoff, H., Krautwald-Junghanns, M.-E. and Erhard, M. (2013): Auswirkungen des Stallklimas auf die Fußballengesundheit von Mastputen der Herkunft B.U.T. 6 in der Aufzuchtphase. Berl. Munch. Tierarztl. 126:181-188. 


\section{Chapter 2 - Thesis Objectives}

The overall objective of the thesis was to investigate the factors foot pad health and mortality for their suitability and application in an indicator-based flock management in broilers and turkeys. It was the objective of the first study (Chapter 3 ) to detect the status quo of weekly mortality and foot pad health in several turkey farms, to derive target values and threshold values, and to indicate and define time frames of higher risk for those indicators. Foot pad alterations were already detected from the rearing period but target and threshold values have not been examined in turkey flocks. As the main influence on foot pad health litter quality has been proven in former studies but specific suggestions for litter management were not published yet. Hence, in this study data about litter management were examined in relation to foot pad health, and management measures were derived.

The assessment method of foot pad health was evaluated (Chapter 4) to issue generally valid threshold values from results of the second study. So far, several assessment schemes were published and a consistent approach has been missed. Therefore, the content of the paper was the elaboration and evaluation of several criteria and their suitability for a foot pad assessment. First, as an on-farm tool as part of an early flock detection and secondly, as part of a feedback-system to reflect success and failure of management measures - on-farm and post mortem. Possible faults due to optical illusion and misinterpretations, when applying current assessment schemes, were considered.

The aim of the third paper (Chapter 5) was to test and evaluate a possible management measure to improve foot pad health in broiler flocks. Previous studies and recommendations about litter amendments were carried out under broiler husbandry conditions in North America. Thus, a pH-reducing litter amendment was applied under consideration of the European and German legislation for broiler husbandry. Those results from a field study, e.g. foot pad health, hock burns and litter parameters as well, were published the first time. Recommendations and limitations regarding that management measure, with focus on animal-related indicators, were derived. 
Development of mortality and foot pad health in turkey flocks and its implication for welfare assessment

\section{Chapter 3}

Development of mortality and foot pad health in turkey flocks and its implication for welfare assessment

Berliner Münchner Tierärztliche Wochenschrift 130 (2017) 258-265

DOI 102376/0005-9366-16044 
Development of mortality and foot pad health in turkey flocks and its implication for welfare assessment

Development of Mortality and Foot pad health in turkey flocks and its implication for welfare assessment

Verlauf der Mortalität und Fußballengesundheit in Putenbeständen im Zusammenhang mit indikatorbasiertem Herdenmanagement

Kathrin Toppel ${ }^{1}$, Falko Kaufmann ${ }^{1}$, Hans Schön ${ }^{1}$, Matthias Gauly ${ }^{2}$, Robby Andersson ${ }^{1}$

${ }^{1}$ Faculty of Agriculture, University of Applied Sciences Osnabrueck, Osnabrueck, Germany

${ }^{2}$ Faculty of Science and Technology, Free University Bozen-Bolzano, Bolzano, Italy 
Development of mortality and foot pad health in turkey flocks and its implication for welfare assessment

\section{Zusammenfassung}

Tierbezogene Merkmale, sog. Tierschutzindikatoren, müssen seit dem 1.2.2014 durch den Tierhalter bzw. Tierbetreuer verpflichtend durch das deutsche Tierschutzgesetz erhoben und bewertet werden (TierSchG 2015). Zuvor wurde u.a. im Animal Welfare Protocol eine Empfehlung zur Erhebung und Bewertung verschiedener Indikatoren im Bestand herausgegeben, die einen Hinweis auf das Tierwohl geben (Welfare Quality 2009). In einer Feldstudie wurden die Mortalität und die Fußballengesundheit über ein Jahr in putenhaltenden Betrieben als Teil der Bestandskontrolle erhoben und bewertet. Die Bonitur der Fußballen erfolgte im vierwöchigen Intervall mit dem Ziel, Risikobereiche herauszuarbeiten, die im Sinne eines Indikators als früher Hinweisgeber relevant für die betriebliche Eigenkontrolle sind. Daten zum Einstreumanagement wurden erhoben um geeignete Maßnahmen zur Prävention von Fußballenveränderungen (FPD) herauszuarbeiten. Grundlage der Mortalitätsauswertungen und der Identifizierung von Risikobereichen bildeten die täglichen Betriebsaufzeichnungen. Die Ergebnisse der Mortalität zeigen, dass Verluste der ersten 7 Lebenstage die Höhe der Gesamtmortalität in der Aufzucht bestimmen. Die wöchentliche Mortalität der Hähne ist im Sommer ein halbes Prozent höher als im Winter. Risikoabschnitte der Hahnenmortalität sind im Sommer von der 12. auf die 13. Lebenswoche (LWo), 14. auf die 15. LWo und 20. auf 21. LWo (Mastende). Im Winter ebenfalls von der 14. auf die 15. LWo. Das besondere Risikofenster für FPD liegt in den ersten acht Lebenswochen. Das Einstreumanagement hat einen signifikanten Einfluss auf FPD.

Schlüsselwörter: Puten, Mortalität, Pododermatitis, Fußballen, Indikatoren

\section{Summary}

Since February 2014 the German Animal Protection Act obligates herd managers to monitor and evaluate animal-related indicators for their livestock (TierSchG 2015). Before that, i.a. within the Welfare Quality Protocol recommendations for monitoring and evaluating welfare-related indicators were published (Welfare Quality 2009). 
Development of mortality and foot pad health in turkey flocks and its implication for welfare assessment

With focus on mortality and foot pad health those data from turkey farms were monitored and evaluated over one year. Foot pads were scored in four week intervals to identify time frames of risk which are relevant within the meaning of selfmonitoring. Litter management-related data were collected to work out successful measures for preventing FPD. Furthermore, mortality data and frames of risk for mortality are based on farm records. Results for mortality show a positive correlation between seven-day and overall mortality of rearing period. The weekly mortality of toms increased about 0.5 percent in the summer compared to the winter cycle. Time frames for an increased risk of male mortality during summer cycle were from week 12 to 13 , week 14 to 15 and week 20 to 21 , respectively. The time frame week 14 to week 15 could be confirmed for winter cycle. Results of FPD indicate an increased risk of foot pad lesions between the first and eights week of life. Litter management influenced FPD prevalence significantly.

Keywords: Turkey, mortality, pododermatitis, indicator, welfare

\section{Introduction}

Consumer's awareness of how animals are being kept for food production rapidly increased over the last decade. As a consequence, animal welfare and especially the assessment of animal welfare was and still is a focal point in several fields of research (WBA 2015). There is consensus at numerous trade groups and science that animal welfare assessment heavily relies on the measurement and evaluation of environmental and animal related signals (Blockhuis et al. 2013). In order to enhance animal welfare and health in German animal husbandry, responsible animal owners and herd managers have to monitor and evaluate animal-related indicators as stated by the Animal Protection Act (TierSchG 2015). Additionally, special legally binding regulations for turkey production, 'Bundeseinheitliche Eckwerte für eine freiwillige Vereinbarung zur Haltung von Mastputen' contain a certain health program which also requests the use of indicators to assess the flocks' health and welfare (VDP 2013). In order to implement/establish a sophisticated health and welfare program the herd manager need to rely on suitable indicators (Andersson et al. 2015) allowing the herd 
Development of mortality and foot pad health in turkey flocks and its implication for welfare assessment

manager to assess flocks' health and welfare retrospectively (monitoring) but also to act prospectively (controlling) (Toppel et al. 2013). Those indicators rely on several parameters and measurements whereas the herd manager has to define target figures for a certain parameter and the respective tolerable deviation (Toppel et al. 2013). It has been shown that mortality is an economically - and more importantly - a welfare related issue (Julian 2004). Besides pathogen-induced diseases, mortality in turkey production is mainly caused by respiratory disorders, cardiovascular diseases and digestive malfunction (Hafez 1999, Mailyan 2014). Furthermore, leg disorders (Hauck 2014) and, with the ban of beak trimming coming into force in 2018, injurious pecking/ cannibalism are discussed as considerable animal welfare problems and also as main causes for mortality (Spindler and Hartung 2013, Hauck 2014). Mortality rates are influenced by sex and season (Rudolf 2008, Damme 2015). Whereas late mortality is mostly a problem in male turkeys (Clark and Bailey 2014), first week mortality was shown to be a suitable indicator for performance of broilers during the rearing period (Yassin et al. 2009). However, in order to evaluate mortality as a welfare-related indicator little deviations need to be detected early and require cause analysis.

Foot pad health is another welfare related issue in turkey production (Youssef et al. 2010) and thus a suitable indicator when assessing animal welfare. Alterations at the plantar region of the feet can cause lameness and immobilization (Da Costa et al. 2013, Hocking and Wu 2013). Furthermore, body weight development can be influenced by foot pad lesions (Da Costa et al. 2014). The relevance of welfare in context with foot pad lesions was indicated by Buda et al. (2002). They proved the existence of sensory nerve endings from mechano- and pain receptors in the plantar area of feet. Therefore, every herd manager is responsible to apply suitable management measures to minimize the risk of foot pad lesions which can be wide-spread in flocks (Grosse Liesner 2007, Spindler 2007, Krautwald-Junghanns et al. 2011, Allain 2013, Bergmann et al. 2013). Pododermatitis is influenced by different factors (Kamphues et al. 2011), e.g. diet (Eichner et al. 2007, Abd-El Wahab et al. 2014), litter material and litter quality (Berk 2007, Rudolf 2008, Youssef et al. 2010, Abd El-Wahab 2011) particularly litter moisture (Martland 1984, Mayne et al. 2006, Wu and Hocking 2011, Youssef et al. 2011, Abd El-Wahab et al. 2012). For both indicators, mortality and foot pad health, 
Development of mortality and foot pad health in turkey flocks and its implication for welfare assessment

detailed information for the risk of occurrence as influenced by time and management measures are currently lacking. However, those information are essential when developing an appropriate on-farm welfare assessment. Therefore, the aim of the current study was to detect the status quo of weekly mortality and foot pad health in several turkey flocks to derive target and threshold values and to indicate and define time frames of greater risk, taking management measures into account.

\section{Material and method}

\section{Animals and housing}

Data from two consecutive production cycles were collected over one year (October 2013 until October 2014) on 13 farms (four rearing farms, four fattening farms and five combined farms), located in North West Germany. On rearing farms, day old turkey chicks were kept until an age of 35 days (rearing period) and then rehoused for the fattening period (day 35 until slaughter). On combined farms, birds remained in the rearing barn for the fattening period. The average flock size for males and females were 10,100 (+/- 4,221) and 5,575 (+/- 1,150). Overall, data from 85,000 males and 18,500 females were collected and analyzed per cycle. Data collection included 30 male flocks (16 in winter and 14 in summer season) and seven female flocks (four in winter and three in summer season). A flock was defined as a group of animals which were placed in the same barn. Flocks from October 2013 until March 2014 were defined as winter flocks, when birds were kept from April until October, they were so called summer flocks. The dominant genetic was B.U.T. 6 (31 flocks), followed by B.U.T. 7 (4 male flocks) and B.U.T. TP7 (2 flocks, male and female). The average rearing period was $31.2(+/-3.4)$ days. Fattening period for females ended up after $113.6(+/-2.1)$ and for males after 145.8 (+/- 3.1) days of life. Barns for rearing were forced-ventilated or open house barns, whereas all fattening barns were open houses with curtains. Litter material differed between farms and production periods. During rearing the bedding material was either wood shaving or straw pellet whereas all animals were kept on straw during fattening. 
Development of mortality and foot pad health in turkey flocks and its implication for welfare assessment

\section{Data collection}

Each single flock was monitored in four week intervals. Farm individual information related to management were evaluated before and during the trial using a questionnaire and flock documentation. The mortality (two times a day) and litter management (material, amount and dispersing intervals) were recorded by the herd managers.

Foot pad health assessment: Starting with the first week of life until slaughtering, foot pads of 60 randomly selected birds per flock were scored in four week intervals. Hens were scored until week 16 , the last date of foot pad scoring of toms was at slaughtering. The plantar area of both foot pads of individual birds were scored according to the five-point scale from Hocking et al. (2008). The score ranges from 0 (no external signs of foot pad dermatitis, swelling or necrosis) to 4 (visible epithelial lesions, massive hyperkeratosis and necrotic area more than half of the plantar area). The depth of a lesion was not recorded. Inter-observer consistency in farm scoring between the two persons, who monitored foot pad health in this project, was checked before data collection. Therefore, 200 pairs of foot pads from 200 slaughtered turkeys were scored and Kendall- Tau- $\mathrm{b}$ was calculated $(\mathrm{r}=0.949 ; \mathrm{p}<0.01)$. Overall 22.800 feet were scored, i.e. 11.400 pair of feet (number of female turkey: 1.920 and of male: turkey: 9.480).

Statistical analysis: Descriptive analysis with median and interquartile range (IQR) was performed for percentage of total losses in different periods during rearing and fattening periods. Spearman correlation was computed to investigate the relation between first week and cumulative mortality until 35 days of life. Rearing period was defined from $1^{\text {st }}$ until $35^{\text {th }}$ day of life by a group of professionals, who gave advice and support to the project. Time frames for mortality risk were evaluated by dividing overall weekly mortality in first, second and third quartile. Time frames for the mortality risk were only analysed in male flocks due to low flock numbers in females. The results of foot pad scoring at different weeks of age are presented as arithmetic mean, standard deviation and median of grouped data, whereas the highest score between the two feet of an individual was considered. Differences between the characteristic values of the attribute , litter dispersing interval during fattening' (dichotomous; categories 2-3 and 4-6 times/ week) were tested by Mann-Whitney U- 
Development of mortality and foot pad health in turkey flocks and its implication for welfare assessment

test $(p<0.05)$. Stepwise forward multiple regression analysis (SPSS Vs.22) was used at the $95 \%$ significance level to analyse the effect of different litter variables on foot pad score at flock level.

The following regression model was constructed:

$\mathrm{y} 1,2=\beta 0+\beta 1 * x 1+\beta 2 * x 2+\beta 3 * x 3+\beta 4 * x 4+\beta 5 * x 5$

$\mathrm{y} 1=$ FPD 16 th week of life; $\mathrm{y} 2=$ FPD $20^{\text {th }}$ week of life,

$\mathrm{x} 1=$ litter dispersing interval during fattening (0-1, 2-3, 4-6 times/ week)

$\mathrm{x} 2$ = time of starting litter dispersing in fattening period (5., 7.-8. or 11. week of life)

x3 = litter amount rearing period $\left(0.8-3.8,3.9-5.9,6.0-8.4 \mathrm{~kg} / \mathrm{m}^{2}\right)$

$\mathrm{x} 4=$ litter amount fattening period $\left(0-8,8.1-16,16.1-24 \mathrm{~kg} / \mathrm{m}^{2}\right)$

x5 = litter material (straw pellet, wood shaving)

Only significant influences are discussed. Further farm individual management aspects with influence on foot pad health were analyzed descriptively.

\section{Results}

\section{Mortality}

Mortality rates were influenced by sex and season (Table 7). During the rearing periods in winter season the median of the seven-day mortality was $0.90 \%$ for female and $0.70 \%$ for male turkeys, respectively. During summer cycle seven day mortality of female turkeys was again $0.20 \%$ higher compared to male turkeys (1.20\% versus 1.00 $\%)$. During winter cycle the cumulative mortality of female turkeys after rearing period (1. until 35. day) was $0.30 \%$ higher than male mortality, whereas no such differences in summer cycles.

The Spearman correlation between first 7-day mortality and cumulative 35-day mortality was significantly positive $(\mathrm{r}=0.677 ; \mathrm{p}<0.01)$. Investigating the mortality in hens, correlation coefficient ranks from $\mathrm{r}=1.000$ ( $\mathrm{p}<0.01 ; 3$ flocks in summer cycle) to $\mathrm{r}=-0.105$ ( $\mathrm{p}=0.895 ; 4$ flocks in winter cycle). In contrast, Spearman-Rho correlation for mortality in toms in the summer cycle resulted in $r=0.385(p=0.217)$. When analyzing the 16 male flocks in winter the correlation was significant with $\mathrm{r}=0.918$ 
Development of mortality and foot pad health in turkey flocks and its implication for welfare assessment

day mortality is $\mathrm{y}=0.86+1.26 * \mathrm{x}$.

Time frames of mortality risk are shown in Figure 2 and Figure 3. If the deviation (delta) of the $3^{\text {rd }}$ quartile between two sequenced weeks increased over 0.24 those weeks were considered as a time frame for mortality risk. The $3^{\text {rd }}$ quartile of mortality increased during winter cycle between week 14 and 15 from $0.69 \%$ to $0.93 \%$ weekly mortality (Figure 2). Figure 3 shows an increasing course of the $3^{\text {rd }}$ quartile during summer cycle from week 12 to $13(0.39 \%$ to $1.21 \%)$ as well as week 14 to $15(0.59 \%$ to $1.03 \%$ ). Another peak during the summer cycle was in week 21 when the $3^{\text {rd }}$ quartile of weekly mortality increased up to $1.03 \%$ (Figure 2). During winter cycle, weekly mortality did not attain the $1 \%$ - threshold. Contrarily, $25 \%$ of the flocks $\left(1^{\text {st }}\right.$ quartile) had a maximum weekly mortality of $0.42 \%$ in the week 21 , the rest of fattening mortality rate did not increase over $0.4 \%$. Compared to that, the $1^{\text {st }}$ quartile of weekly mortality was over $0.4 \%$ in the last three weeks before slaughtering (week 19 to 21 ) during summer cycle, with a maximum of $0.75 \%$. Even if half of the flocks (median) just reached $0.84 \%$ mortality rate in week 21 during summer cycle, the maximum weekly mortality rate during the remaining weeks was $0.67 \%$.

Table 7: Mortality of birds in different stages of life depending on sex and season (Median and Interquartile range (IQR))

\begin{tabular}{|c|c|c|c|c|c|}
\hline & \multicolumn{2}{|c|}{ Female } & \multicolumn{2}{|c|}{ Male } \\
\hline & & winter & summer & winter & summer \\
\hline $\mathrm{n}$ (animals/ flo & & $21,800 / 4$ & $17,500 / 3$ & $86,600 / 16$ & $82,100 / 14$ \\
\hline $\begin{array}{l}\text { 7-day } \\
\text { Mortality } \\
\text { (cumulative) }\end{array}$ & $\begin{array}{l}\text { Median } \\
\text { (IQR) }\end{array}$ & $0.90(0.40)$ & $1.20(0.86)$ & $0.70(0.32)$ & $1.00(1.21)$ \\
\hline $\begin{array}{l}\text { 1.-35. day of } \\
\text { life } \\
\text { (cumulative) }\end{array}$ & $\begin{array}{l}\text { Median } \\
\text { (IQR) }\end{array}$ & $2.10(0.37)$ & $1.80(1.20)$ & $1.80(0.38)$ & $1.80(1.49)$ \\
\hline $\begin{array}{l}\text { 1.-5. week of } \\
\text { life (average } \\
\text { per week) }\end{array}$ & $\begin{array}{l}\text { Median } \\
\text { (IQR) }\end{array}$ & $0.38(0.51)$ & $0.19(0.31)$ & $0.35(0.44)$ & $0.40(0.41)$ \\
\hline $\begin{array}{l}6 .-16 . / 21 \\
\text { week of life } \\
\text { (average per } \\
\text { week) }\end{array}$ & $\begin{array}{l}\text { Median } \\
\text { (IQR) }\end{array}$ & $0.19(0.18)$ & $0.16(0.41)$ & $0.38(0.43)$ & $0.43(0.48)$ \\
\hline
\end{tabular}


Development of mortality and foot pad health in turkey flocks and its implication for welfare assessment

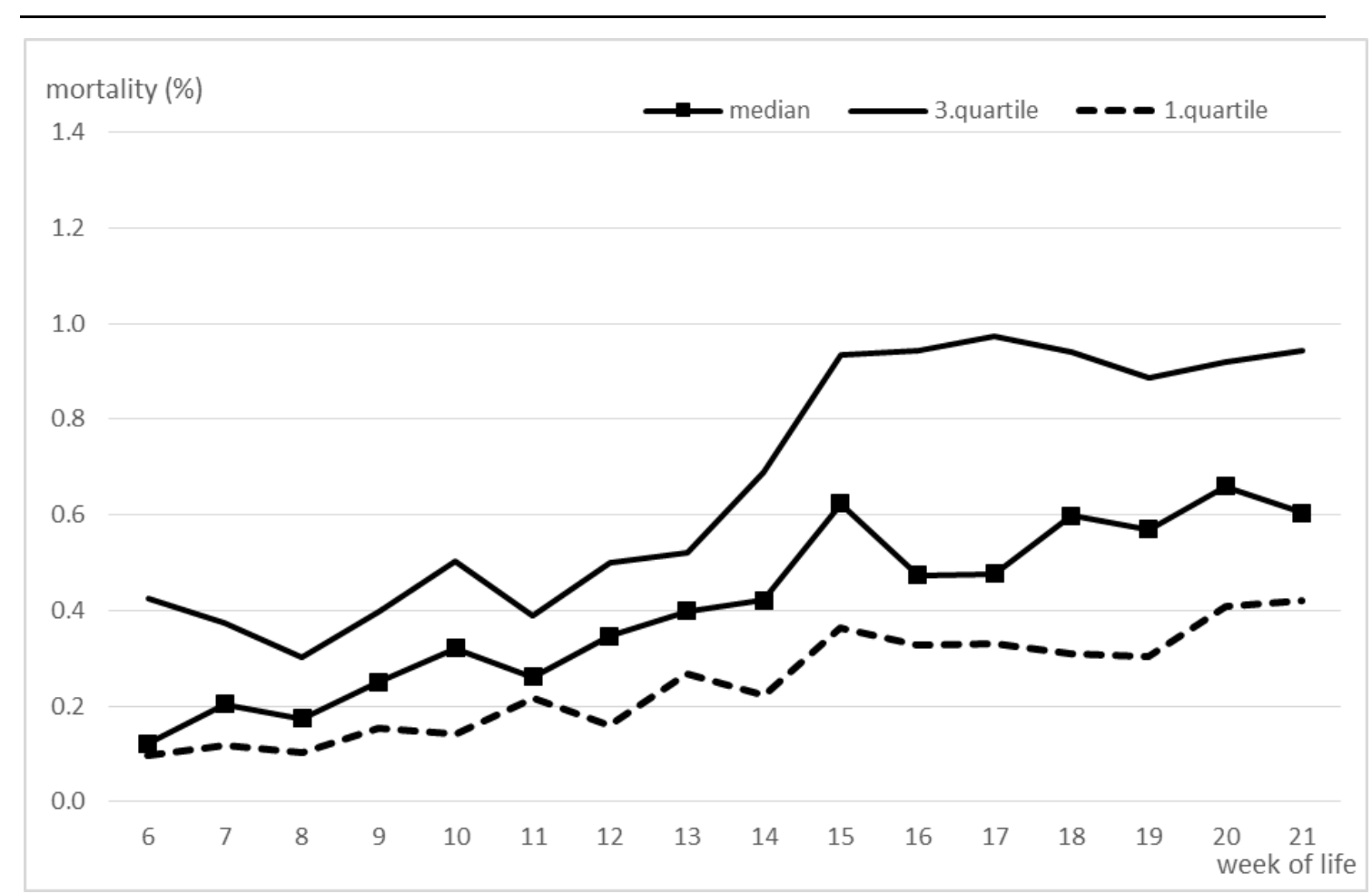

Figure 2: Average weekly mortality (\%) of toms during winter cycle ( $n=16$ flocks)

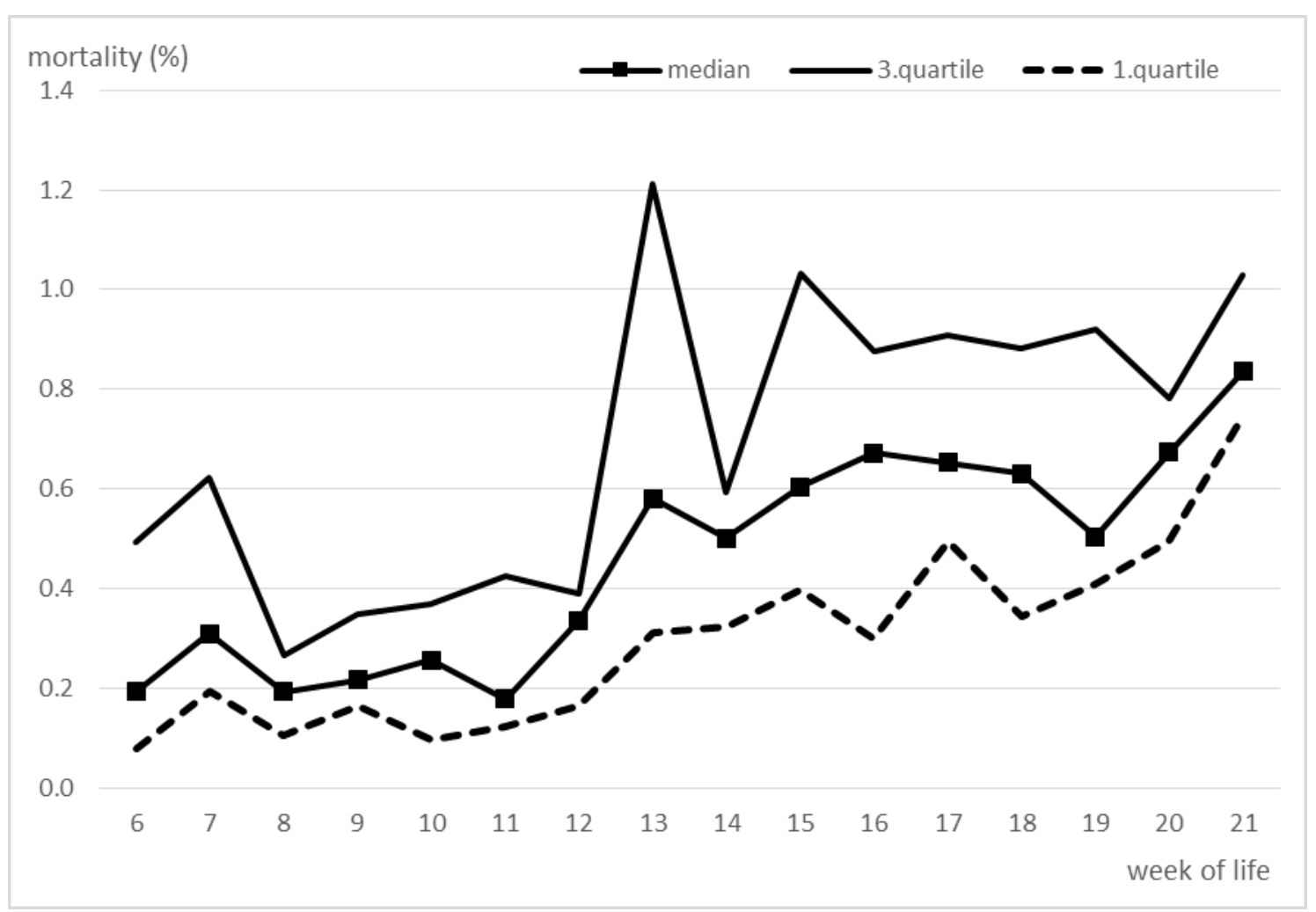

Figure 3: Average weekly mortality (\%) of toms during summer cycle ( $n=14$ flocks) 
Development of mortality and foot pad health in turkey flocks and its implication for welfare assessment

\section{Foot pad health}

Results of foot pad scoring are presented in Table 8. There were obvious differences between sex and season as indicated by the data. Foot pad alterations increased with age. The first lesions were evaluated within the first week of life. During fattening period ( $8^{\text {th }}$ to $16^{\text {th }}$ week of life) lesions of hens were at least as highly developed or worse than those of toms. The maximum median value is score 2.35 for male turkeys and 2.32 for females, both at date of slaughtering. Independent from sex and season, the time frame of the risk for developing foot pad lesions strongly correlates with the rearing period and the beginning of fattening. High differences occurred between week four and eight.

Influences on foot pad lesions: Different predictors with a possible impact on foot pad health were calculated with multiple regression analysis. From all predictors which were tested, 'weekly litter dispersing frequency' and 'litter amount in fattening period' were the parameters which were most associated with foot pad dermatitis. Pododermatitis of male turkeys at market age was significantly influenced by the amount of bedding material during fattening $\left(\mathrm{R}^{2}=0.478, \mathrm{SE}=0.017 ; \mathrm{p}=0.012\right)$. The correlation between the predictors 'weekly litter dispersing frequency' and 'litter amount in fattening period' was 0.764 (Spearman). When litter dispersing was performed two or three times a week the total amount of litter used during one fattening cycle ranged between 11.2 until $14.2 \mathrm{~kg}$ straw $/ \mathrm{m}^{2}$. When increasing the dispersing frequency to four until six times a week, 17.5 to $22.6 \mathrm{~kg}$ straw $/ \mathrm{m}^{2}$ was used over the course of a fattening period. Animals of flocks with less bedding material had an average foot pad score of 2.2 (median) compared to 2.7 in toms, which were fattened on more litter material. 
Development of mortality and foot pad health in turkey flocks and its implication for welfare assessment

Table 8: Arithmetic mean (Mean), Grouped median (Median) and Standard deviation (SD) of foot pad scores on farms (week 1 until 16) and at slaughterhouse (post mortem, p.m.) depending on sex and season

\begin{tabular}{|c|c|c|c|c|c|c|}
\hline \multirow{2}{*}{$\begin{array}{l}\text { Week } \\
\text { of life }\end{array}$} & \multicolumn{3}{|c|}{ Female } & \multicolumn{3}{|c|}{ Male } \\
\hline & & winter cycle & summer cycle & & winter cycle & summer cycle \\
\hline 1 & $\begin{array}{l}\mathrm{n} \\
\text { Mean } \\
\text { SD } \\
\text { Median }\end{array}$ & $\begin{array}{c}220 \\
0.85 \\
0.83 \\
0.75^{\mathrm{a}}\end{array}$ & $\begin{array}{c}180 \\
0.00 \\
0.00 \\
0.00^{\mathrm{b}}\end{array}$ & $\begin{array}{l}\mathrm{n} \\
\text { Mean } \\
\text { SD } \\
\text { Median }\end{array}$ & $\begin{array}{c}661 \\
0.79 \\
0.76 \\
0.73^{\mathrm{a}}\end{array}$ & $\begin{array}{c}720 \\
0.16 \\
0.37 \\
0.16^{\mathrm{b}}\end{array}$ \\
\hline 4 & $\begin{array}{l}\mathrm{n} \\
\text { Mean } \\
\text { SD } \\
\text { Median }\end{array}$ & $\begin{array}{c}240 \\
0.57 \\
0.58 \\
0.55^{\mathrm{a}}\end{array}$ & $\begin{array}{c}180 \\
0.43 \\
0.51 \\
0.42^{b}\end{array}$ & $\begin{array}{l}\mathrm{n} \\
\text { Mean } \\
\text { SD } \\
\text { Median }\end{array}$ & $\begin{array}{c}839 \\
0.96 \\
0.96 \\
0.84^{\mathrm{a}}\end{array}$ & $\begin{array}{c}840 \\
0.67 \\
0.75 \\
0.60^{\mathrm{b}}\end{array}$ \\
\hline 8 & $\begin{array}{l}\mathrm{n} \\
\text { Mean } \\
\text { SD } \\
\text { Median }\end{array}$ & $\begin{array}{c}240 \\
1.92 \\
0.49 \\
1.91^{\mathrm{a}} \\
\end{array}$ & $\begin{array}{l}180 \\
1.62 \\
0.49 \\
1.62^{\mathrm{b}}\end{array}$ & $\begin{array}{l}\mathrm{n} \\
\text { Mean } \\
\text { SD } \\
\text { Median }\end{array}$ & $\begin{array}{l}873 \\
1.68 \\
0.51 \\
1.68^{\mathrm{a}} \\
\end{array}$ & $\begin{array}{l}1140 \\
1.34 \\
0.48 \\
1.34^{\mathrm{b}}\end{array}$ \\
\hline 12 & $\begin{array}{l}\mathrm{n} \\
\text { Mean } \\
\text { SD } \\
\text { Median }\end{array}$ & $\begin{array}{c}240 \\
2.29 \\
0.73 \\
2.31^{\mathrm{a}} \\
\end{array}$ & $\begin{array}{c}180 \\
1.91 \\
0.45 \\
1.90^{\mathrm{b}} \\
\end{array}$ & $\begin{array}{l}\mathrm{n} \\
\text { Mean } \\
\text { SD } \\
\text { Median }\end{array}$ & $\begin{array}{l}1050 \\
1.77 \\
0.69 \\
1.75^{\mathrm{a}} \\
\end{array}$ & $\begin{array}{l}1040 \\
1.61 \\
0.53 \\
1.60^{\mathrm{b}} \\
\end{array}$ \\
\hline 16 & $\begin{array}{l}\mathrm{n} \\
\text { Mean } \\
\mathrm{SD} \\
\text { Median }\end{array}$ & $\begin{array}{c}240 \\
2.27 \\
0.66 \\
2.26^{\mathrm{b}} \\
\end{array}$ & $\begin{array}{l}120 \\
2.31 \\
0.61 \\
2.32^{\mathrm{a}} \\
\end{array}$ & $\begin{array}{l}\mathrm{n} \\
\text { Mean } \\
\mathrm{SD} \\
\text { Median }\end{array}$ & $\begin{array}{l}1090 \\
2.33 \\
0.86 \\
2.29^{\mathrm{a}} \\
\end{array}$ & $\begin{array}{c}1080 \\
1.89 \\
0.71 \\
1.86^{\mathrm{b}}\end{array}$ \\
\hline p.m. & & no evaluati & & $\begin{array}{l}\mathrm{n} \\
\text { Mean } \\
\text { SD } \\
\text { Median }\end{array}$ & $\begin{array}{l}840 \\
2.35 \\
0.86 \\
2.35^{\mathrm{a}}\end{array}$ & $\begin{array}{c}1173 \\
2.15 \\
0.67 \\
2.16^{\mathrm{b}}\end{array}$ \\
\hline
\end{tabular}

\section{Discussion}

In order to continuously improve animal health and welfare turkey husbandry should be performed based on the use of health and welfare indicators. In addition to the legal basis of the German Animal Protection Act indicators may become a useful and essential part of a controlling system for the management of turkey flocks.

Results of mortality of hens and toms were influenced by sex and season. Those results correspond with earlier studies, where mortality rates of toms ranged from about $9 \%$ (Krautwald-Junghanns and Fehlhaber 2009) to 10.33\% (Damme 2015) during fattening periods, whereas female mortality was around $4 \%$ (Krautwald-Junghanns 
Development of mortality and foot pad health in turkey flocks and its implication for welfare assessment

and Fehlhaber 2009, Damme 2015). Thus, male mortality tends to be twice as high when compared to female mortality. In another study female mortality was $5.6 \%$ during summer cycle whereas male mortality reached 14.6\% (Rudolf 2008). Despite the sex effect, those results indicate a strong seasonal effect as shown in the current study. However, the low number of female flocks must be taken into account when interpreting the results from the present study. In the first week mortality rate was positively correlated $(r=0.677)$ to the cumulative rearing mortality without any sex differences. Therefore, a high number of losses within the first week of age did not lead to a less number of losses in the remaining rearing period which is often hypothesised in the practice. As main causes for losses in the first time of rearing period Kulke et al. (2014) reported navel and yolk sac infection. Investigation in broiler flocks showed a significant relation between first week mortality and breeder related issues like breeder age, strain and hatchery (Yassin et al. 2009). Wojcinski (2014) stressed out the meaning of a proper flock management in the barn within the first few days after hatching. The high variation of the mortality rates between farms support Wojcinski (2014) and indicates huge farm effects. Those outcomes are supported by the development of mortality rates during fattening period. Mortality rates in Figure 2 and Figure 3 show a high deviation between flocks within the $1^{\text {st }}$ and above the $3^{\text {rd }}$ quartile. Although all courses of mortality increase with age, the curve shapes of the $1^{\text {st }}$ quartile and median are more linear and with less peaks compared to the $3^{\text {rd }}$ quartile. The high risk time frame for male mortality was equal in all flocks during winter and summer cycle (week 14 to 15). Additionally, week 12 to 13 in summer seasons may also harbors higher mortality risks. According to Hafez (2006), certain health problems like aortic rupture, sudden death, dyschondroplasia and deep pectoral myopathy are far more relevant than the susceptibility for infectious diseases. Fattening turkeys are most susceptible for diseases like aortic rupture between 12 to 16 weeks of age. Especially between weeks 8 to 14 sudden death harbours a risk for male turkeys (Hafez 2006). Causes are seen in inappropriate flock management as sudden death may be supported by hyperactivity and crowding, while death after aortic rupture may be caused by stress due to disquiet in the barn or stocking density. The fact that at least $25 \%$ of the summer flocks in the present study showed weekly mortality rates over $0.8 \%$ from week 15 until the end of fattening corresponds with 
Development of mortality and foot pad health in turkey flocks and its implication for welfare assessment

Clark and Bailey (2014) who reported about late mortality as a problem in male flocks especially in the summer season. The authors explained it in context with aggressive behavior and cannibalism as well as leg problems and/ or hypertension (Clark and Bailey 2014). The influence of heat stress (seasonal effect) on mortality is very well known (Evans et al. 2000) and thus, appropriate management measures are provided in 'Bundeseinheitliche Eckwerte' (VDP 2013). The present results indicate that more on-farm measurements are needed. This, however, requires a continuous evaluation of losses especially in the first week of life as well as from week 12 ongoing. More investigation need to be done in order to explain main reasons for the increased mortality from week $13 / 14$ until slaughtering. That would allow to derive countermeasures which is from great importance not only regarding animal welfare aspects but also to maintain and increase production efficiency which includes economic and ecological aspects. Possible actions to prevent e.g. heat stress could be fan arrangements with spray cooling (Da Costa et al. 2013), postponing feeding time from noon to evening (VDP 2013) or dietary supplementation of vitamins (Lin et al. 2006, VDP 2013).

The early beginning of foot pad lesions corresponds with results from other studies (Mayne et al. 2006, Bergmann et al. 2013). In the present study turkey poults already developed alterations on foot pads (hyperkeratosis and hyperkeratosis with adhesive dirt) within the first week of life. The higher prevalence of lesions during the winter cycle is in accordance with Mayne (2005), Rudolf (2008) and Da Costa et al. (2014) and can be explained with warm ambient temperature that promotes the maintenance of dry litter in the barn (Mayne 2005). Contrarily, the lack of heating combined with high condensation/evaporation increases the moisture content of litter in fall and winter cycles and thus, increases the risk for adverse foot pad condition (Mayne et al. 2007b, Youssef et al. 2010, Wu and Hocking 2011, Youssef et al. 2011, Abd El-Wahab et al. 2012, De Jong et al. 2012). Researchers defined a moisture content of 30 to $35 \%$, in combination with an exposition time between four and 48 hours as most critical for the development of foot pad lesions (Mayne et al. 2007a, Youssef et al. 2011, Abd ElWahab et al. 2012). According to Kamphues (2014) litter moisture should not exceed $25 \%$ in order to promote foot pad health. However, suitable on-farm methods for its measurement is currently lacking and needs to be developed (Krautwald-Junghanns et 
Development of mortality and foot pad health in turkey flocks and its implication for welfare assessment

al. 2009). To prevent the contact between wet litter and foot pads fresh litter dispersing during the rearing and fattening period is a common method. As the present results of male foot pad health during the winter cycle indicates, litter amount during the fattening period significantly correlates with foot pad lesions at time of slaughter. Flocks dispersing fresh litter two to three times a week were scored with better marks compared with animals from flocks with shorter dispersing intervals and finally more bedding material during fattening period. In a former broiler study similar statements were pointed out by Ekstrand et al. (1997). Broilers which were kept under husbandry conditions with higher amounts of bedding material had more and severe lesions at slaughtering compared to broilers from farms with less litter material during production cycle. The litter dispersing interval of two until three times weekly was also documented by Krautwald-Junghanns et al. (2009) as a common treatment. However, the present results indicate that this dispersing frequency complies with an amount of straw around 11.2 to $14.2 \mathrm{~kg} / \mathrm{m}^{2}$. Herd managers who dispersed new bedding four to six times a week, which resulted in worst scored foot pads, had a fixed dispersing interval, e.g. every second day, regardless of the necessity of new litter in the barn or moisture content of the litter. Especially during winter time, it is a problem to get water out of the straw bedding (Kamphues 2014). In contrast to a fixed dispersing interval, herd managers who brought in new bedding material two until three times a week decided in dependence of constitution of the animals as well as environmental factors. Preliminary results from the present study showed that farmers who provided new material in the barn two or three times per week, also decreased their litter dispersing interval over a limited period of time. Those flocks received 0.5 $0.6 \mathrm{~kg} / \mathrm{m}^{2}$ more litter material either between week ten until week twelve or from week seven until week twelve. In that cases management measures were related to changes in feeding regime (phase feeding). In that phase, stockpersons expected an increased moisture content due to watery/humid excrements and also diarrhea. As described by Kamphues (2014) water content in excrements is one of the main reasons for wet litter. Critically discussed are diets with excessive amounts of renal eliminated nutrients (e.g. sodium, potassium) which provoke high water consumption (Youssef et al. 2011, Abd El-Wahab et al. 2014). Spindler (2007) proved a relation between the prevalence of diarrhea and an increasing severity and prevalence of foot pad lesions. Also Abd El- 
Development of mortality and foot pad health in turkey flocks and its implication for welfare assessment

Wahab (2011) proved the negative influence of coccidiosis as a disease causes diarrhea and thus wet litter. Another preliminary result is the fact that turkeys which are kept on straw pellet during rearing had less foot pad lesions until slaughtering compared to turkeys which were reared on wood shavings. Berk (2007) and Youssef et al. (2010) discussed that with a sharper texture of wood shavings. First micro-lesions can be caused by shaving particles from first week of life and thus, present an entry for pathogens and the fundament of foot pad dermatitis. Furthermore, actual results show differences of foot pad lesions between toms and hens from week eight until week 16 . Hens showed more severely altered foot pad compared to toms. It is discussed in relation with stocking density that keeping more animals per square meter result in more feces related to surface area, especially at the end of the fattening period (Kamphues 2014). However, hens show initially worse scores right in the beginning of the fattening period compared to males. One possible reason could be that females stay on the used bedding material while males are moved in a fattening barn with fresh dry and clean litter material. Foot pad lesions of male turkeys could be healed by scarring. Mayne et al. (2007a) found out that the process of healing takes about 15 days. In the study of Mayne et al. (2007a) turkeys were kept on wet litter until a macroscopic score of 6.7 ( $0=$ no lesion until $7=$ high severity of lesions). Subsequently birds were kept only on new dry material. After 15 days macroscopic foot pad lesions were scored between 0 and 0.9 .

Based on that fact, results from the present study give advices to turkey stockpersons when to evaluate foot pad health and how to prevent or minimize foot pad lesions. Knowledge about time frames of risk for foot pad dermatitis enables stockpersons to a more intensive management in certain periods during production cycle. Moreover, management efforts can be reduced in the further production period, when deviations were identified in time. The meaning of controlling during rearing period becomes obvious with results of the present study. The presented data about litter management indicate the importance of adequate litter dispersing intervals and litter amounts based on continuous monitoring and evaluation of flock condition, from right of the beginning of the production period. The present study also pointed out critical time frames for mortality. Furthermore, weekly mortality of different flocks show a high variation between flocks and season and moreover target values with focus on 
Development of mortality and foot pad health in turkey flocks and its implication for welfare assessment

mortality rates of the best quarter of the flocks. Using indicators as part of on-farm controlling the data give support in a demand- and risk-oriented turkey herd management. The results of the temporal course of mortality point out possible target figures, which need to be defined when implementing an indicator-based on-farm controlling system.

Acknowledgements

The project was conducted within the „Tierschutzplan Niedersachsen“. The authors thank the Lower Saxony Ministry of Food, Agriculture and Consumer Protection and the Ministry of Science and Culture of Lower Saxony as well as the German Turkey Industry.

Conflict of interest

All authors declare that there are no conflicts of interest.

\section{References}

Abd El-Wahab, A. (2011): Experimental studies on effects of diet composition (electrolyte contents), litter quality (type, moisture) and infection (coccidia) on the development and severity of foot pad dermatitis in young turkeys housed with or without floor heating. Dissertation, Tierärztliche Hochschule Hannover.

Abd El-Wahab, A., Visscher, C.F., Beineke, A., Beyerbach, M. and Kamphues, J. (2011): Effects of floor heating and litter quality on the development and severity of foot pad dermatitis in young turkeys. Avian Dis. 55: 429-434.

Abd El-Wahab, A., Visscher, C.F., Beineke, A., Beyerbach, M. and Kamphues, J. (2012): Experimental studies on the effects of different litter moisture contents and exposure time to wet litter on development and severity of foot pad dermatitis in young fattening turkeys. Arch. Geflugelkd. 76:55-62.

Abd El-Wahab, A., Schulze Hillert, M., Spindler, B., Hartung, J., Sürie, C. and Kamphues, J. (2014): Effects of diets formulated on all-plant protein basis or including animal protein on foot pad health and performance in fattening turkeys. Europ. Poultry Sci. 78: DOI:10.1399/eps.201438.

Allain, V., Huonnic, D., Rouina, M. and Michel, V. (2013): Prevalence of skin lesions in turkeys at slaughter. Br. Poultry Sci. 54:33-41.

Andersson, R., Toppel, K. and Heesen, S. (2015): Kann man Tierwohl messen? In Damme, K. and Muth, F. (ed.): Geflügeljahrbuch 2016. Ulmer Verlag, Stuttgart, 2432.

Bergmann, S., Ziegler, N., Bartels, T., Hübel, J., Schumacher, C., Rauch, E., Brandl, S., Bender, A., Casalicchio, G., Krautwald-Junghanns, M.E. and Erhard, M.H. (2013): 
Development of mortality and foot pad health in turkey flocks and its implication for welfare assessment

Prevalence and severity of foot pad alterations in Germann turkey poults during the early rearing phase. Poultry Sci. 92:1171-1176.

Berk, J. (2007): Can alternative kinds of litter reduce foot pad lesions in female turkeys? Proceedings of the $4^{\text {th }}$ International Symposium on Turkey Production. Berlin. 143-149.

Blockhuis, H., Jones, B., Veissier, I. and Miele, M. (2013): The Welfare Quality® vision. Introduction. In Improving farm animal welfare- Science and society working together: the Welfare Quality approach. Wageningen Academic Publishers Gelderland, Netherlands. 13-18.

Buda, S., Platt, S. and Budras, K.D. (2002): Sensory nerve endings in the footpads of turkeys. Proceedings of the $4^{\text {th }}$ International Symposium on Turkey Diseases. Berlin. $78-82$.

Clark, S. and Bailey, A. (2014): Current health and industry issues facing the turkey industry. Proceedings of $10^{\text {th }}$ Hafez International Symposium on turkey diseases. Berlin. 54-62.

Da Costa, M., Grimes, J.L., Oviedo, E., Shah, S., Barasch, I., Evans, C., Black, S., Dalmagro, M. and Nixon, J. (2013): Current Challenges and Opportunities for Turkey Flock Management: Footpad Health and Ventilation. Proceedings of the $7^{\text {th }}$ Hafez International Symposium on Turkey Production. Berlin. 99-105.

Da Costa, M.J., Grimes, J.L., Oviedo-Rondon, E.O., Barasch, I., Evans, C., Dalmagro, M. and Nixon, J. (2014): Footpad dermatitis severity on turkey flocks and correlations with locomotion, litter conditions, and body weight at market age. J. Appl. Poultry Res. 23:268-279.

Damme, K. (2015): Faustzahlen zur Betriebswirtschaft. In: Damme, K. and Muth, F. (ed.), Geflügeljahrbuch 2016. Eugen Ulmer Verlag, Stuttgart, Germany. 92.

De Jong, I.C., Van Harn, J., Gunnink, H., Hindle, V.A. and Lourens, A. (2012): Footpad dermatitis in Dutch broiler flocks: Prevalence and factors of influence. Poultry Sci. 91:1569-1574.

Eichner, G., Vieira, S.L., Torres, C.A., Coneglian, J.L.B., Freitas, D.M. and Oyarzabal, O.A. (2007): Litter moisture and footpad dermatitis as affected by diets formulated on all-vegetable basis or having the inclusion of poultry by-product. J. Appl. Poultry Res. 16:344-350.

Ekstrand, C., Algers, B. and Svedberg, J. (1997): Rearing conditions and foot-pad dermatitis in Swedish broiler chickens. Prev. Vet. Med. 31:167-174.

Evans, R.D., Edson, R.K., Watkins, K.L., Robertson, J.L., Meldrum, J.B. and Novilla, M.N. (2000): Turkey knockdown in successive flocks. Avian Dis. 44:730-736.

Große Liesner, B. (2007): Vergleichende Untersuchungen zur Mast- und Schlachtleistung sowie zum Auftreten (Häufigkeit/Intensität) primär nicht-infektiöser Gesundheitsstörungen bei Puten fünf verschiedener Linien. Dissertation, Tierärztliche Hochschule Hannover.

Hafez, H.M. (1999): Gesundheitsstörungen bei Puten im Hinblick auf die tierschutzrelevanten und wirtschaftlichen Gesichtspunkte. Arch. Geflugelkd. 63:7376. 
Development of mortality and foot pad health in turkey flocks and its implication for welfare assessment

Hafez, H.M. (2006): Genetic selection of turkey and health related problems. Proceedings of $6^{\text {th }}$ International Symposium on Turkey Diseases, Berlin. 5-16.

Hauck, R. (2014): "Leg weakness" in turkeys: Reasons and approaches for solutions. Proceedings of $10^{\text {th }}$ Hafez International Symposium on turkey diseases. Berlin, 9-14.

Hocking, P.M., Mayne, R.K., Else, R.W., French, N.A. and Gatcliffe, J. (2008): Standard European footpad dermatitis scoring system for use in turkey processing plants. Worlds Poultry Sci. J. 64:323-328.

Hocking, P.M. and Wu, K. (2013): Traditional and commercial turkeys show similar susceptibility to foot pad dermatitis and behavioral evidence of pain. Br. Poultry Sci. DOI:10.1080/00071668.2013.781265.

Julian, R.J. (2004): Production and growth related disorders and other metabolic diseases of poultry - A review. The Vet. J. 169:350-369.

Kamphues, J., Youssef, I., Abd El-Wahab, A., Üffing, B., Witte, M. and Trost, M. (2011): Influences of feeding and housing on foot pad health in hens and turkeys. Übersichten zur Tierernährung 39:147-193.

Kamphues, J. (2014): Zur Bedeutung von Fütterung und Haltung für die Fußballengesundheit beim Mastgeflügel. Amtstierärztlicher Dienst und Lebensmittelkontrolle. Heft 3.

Krautwald-Junghanns, M.E. and Fehlhaber, K. (2009): Abschlussbericht zum Forschungsauftrag 06HS015 „Indikatoren einer tiergerechten Mastputenhaltung“. Veterinärmedizinische Fakultät Leipzig.

Krautwald-Junghanns, M.E., Ellerich, R., Böhme, J., Cramer, K., DellaVolpe, A., Mitterer-Istyagin, H., Ludewig, M., Fehlhaber, K., Schuster, E., Berk, J., Aldehoff, D., Fulhorst, D., Kruse, W., Dressel, A., Noack, U. and Bartels, T. (2009): Erhebungen zur Haltung und Gesundheit bei Mastputen in Deutschland. Berl. Munch. Tierarztl. Wochenschr. 122:271-283.

Krautwald-Junghanns, M.E., Ellerich, R., Mitterer-Istyagin, H., Ludewig, M., Fehlhaber, K., Schuster, E., Berk, J., Petermann, S. and Bartels, T. (2011): Examinations on the prevalence of footpad lesions and breast skin lesions in British United Turkeys Big 6 fattening turkeys in Germany. Part I: prevalence of footpad lesions. Poultry Sci. 90:555-560.

Kulke, K., Habig, C., Kemper, N. and Spindler, B. (2014): Untersuchungen zum Vorkommen von Kannibalismus bei nicht schnabelgekürzten Putenhähnen bei unterschiedlichen Besatzdichten. Abschlussbericht Tierärztliche Hochschule Hannover.

www.ml.niedersachsen.de\%2Fdownload\%2F94265\%2FAbschlussbericht Besatzdic hte_Puten_Ruthe.pdf\&usg=AFQjCNGh5Zt0wgKRA38TFFmCUHWQeIDMCA\&bv $\mathrm{m}=\overline{\mathrm{b}} \mathrm{v} .137 \overline{1} 32246, \mathrm{~d} . \mathrm{ZGg}$; Download 23.08.2016

Lin, H., Jiao, H.C., Buyse, J. and Decuypere, E. (2006): Strategies for preventing heat stress in poultry. Worlds Poultry Sci. J. 62:71-86.

Mailyan, E.S. (2014): Management related health issues in commercial turkey production. Proceedings of $10^{\text {th }}$ Hafez International Symposium on Turkey Diseases. Berlin. 45-53. 
Development of mortality and foot pad health in turkey flocks and its implication for welfare assessment

Martland, M.F. (1984): Wet Litter as a Cause of Plantar Pododermatitis, Leading to Foot Ulceration and Lameness in Fattening Turkeys. Avian Pathol. 13:241-252.

Mayne, R.K. (2005): A review of the aetiology and possible causative factors of foot pad dermatitis in growing turkeys and broilers. Worlds Poultry Sci. J. 61:256-267.

Mayne, R.K., Hocking, P.M. and Else, R.W. (2006): Foot pad dermatitis develops at an early age in commercial turkeys. Br. Poultry Sci. 47:36-42.

Mayne, R.K., Else, R.W. and Hocking, P.M. (2007a): High litter moisture alone is sufficient to cause foot pad dermatitis in growing turkeys. Br. Poultry Sci. 48:538-545.

Mayne, R.K., Powell, F., Else, R.W., Kaiser, P. and Hocking, P.M. (2007b): Foot pad dermatitis in growing turkeys as associated with cytokine and cellular changes indicative of an inflammatory immune response. Avian Pathol. 36:543-459.

Rudolf, M. (2008): Einfluss von Besatzdichte und Einstreumaterial auf die Pododermatitis bei Mastputen. Dissertation, Freie Universität Berlin.

Spindler, B. (2007): Pathologisch-anatomische und histologische Untersuchungen an Gelenken und Fußballen bei Puten der Linie B.U.T. Big 6 bei der Haltung mit und ohne Außenklimabereich. Dissertation, Tierärztliche Hochschule Hannover.

Spindler, B. and Hartung, J. (2013): Gegenwärtige Management- und Haltungsbedingungen bei nicht schnabelgekürzten Puten in der ökologischen Haltung. Abschlussbericht, Tierärztliche Hochschule Hannover. www.ml.niedersachsen.de\%2Fdownload\%2F91517\%2FAbschlussbericht_Managem ent-

_und_Haltungsbedingungen_bei_unkupierten_Oekoputen.pdf\&usg=AFQjCNGTUc0 TzDJyJt007XH74hvZF0mnw\& $\bar{b} v m=$ bv.137132246,d.ZGg\&cad=rja; Download 23.08.2016

TierSchG (2015): "Tierschutzgesetz in der Fassung der Bekanntmachung vom 18. Mai 2006 (BGB1. I S. 1206, 1313), das durch Artikel 4 Absatz 87 des Gesetzes vom 18. Juli 2016 (BGBl. I S. 1666) geändert worden ist" http://www.gesetze-iminternet.de/tierschg/BJNR012770972.html; Download am 23.08. 2016.

Toppel, K., Kaufmann, F. and Andersson, R. (2013): The new German backbone of animal protection in turkey production: Health-monitoring or health-controlling? Proceedings of the $7^{\text {th }}$ Hafez International Symposium on Turkey Production. Berlin. 69-71.

VDP (2013): Bundeseinheitliche Eckwerte für eine freiwillige Vereinbarung zur Haltung von Mastputen. Verband Deutscher Putenerzeuger (ed.), Berlin.

WBA, Wissenschaftlicher Beirat Agrarpolitik beim BMEL (2015): Wege zu einer gesellschaftlich akzeptierten Nutztierhaltung. Gutachten. Berlin.

Wojcinski, H.S. (2014): Management and Multiple Disease Challenges: When Worlds Collide. Proceedings of the 8th Turkey Science and Production Conference. Chester, UK, 19-21.

$\mathrm{Wu}, \mathrm{K}$. and Hocking, P.M. (2011): Turkeys are equally susceptible to foot pad dermatitis from 1 to 10 weeks of age and foot pad scores were minimized when litter moisture was less than 30\%. Poultry Sci. 90:1170-1178. 
Development of mortality and foot pad health in turkey flocks and its implication for welfare assessment

Yassin, H., Velthuis, A.G.J., Boerjan, M. and Riel, J. (2009): Field study on broilers' first-week mortality. Poultry Sci. 88:798-804.

Youssef, I., Beineke, A., Rohn, K. and Kamphues, J. (2010): Experimental study on effects of litter material and its quality on foot pad dermatitis in growing turkeys. Int. J. Poultry Sci. 9:1125-1135.

Youssef, I., Beineke, A., Rohn, K. and Kamphues, J. (2011): Effects of Litter Quality (Moisture, Ammonia, Uric Acid) on Development and Severity of Foot Pad Dermatitis in Growing Turkeys. Avian Dis. 55:51-58.

Zapf, R., Schultheiß, U., Achilles, W., Schrader, L., Knierim, U., Herrmann, H.J., Brinkmann, J. and Winckler, C. (2015): Tierschutzindikatoren. Vorschläge für die betriebliche Eigenkontrolle. KTBL Schrift 507, KTBL. Darmstadt. 


\section{Chapter 4}

Foot pad health as part of on-farm-monitoring in turkey flocks

Frontiers in Veterinary Science

DOI: $10.3389 /$ fvets. 2019.00025 


\section{Foot Pad Health as Part of On-Farm-Monitoring in Turkey Flocks}

K. Toppel ${ }^{1}$, B. Spindler ${ }^{2}$, F. Kaufmann ${ }^{1}$, M. Gauly ${ }^{3}$, N. Kemper ${ }^{2}$, R. Andersson ${ }^{1}$

${ }^{1}$ Faculty of Agriculture, University of Applied Sciences Osnabrueck, Osnabrueck, Germany

${ }^{2}$ Institute for Animal Hygiene, Animal Welfare and Farm Animal Behavior, University of Veterinary Medicine Hanover, Foundation, Hannover, Germany

${ }^{3}$ Faculty of Science and Technology, Free University Bozen-Bolzano, Bolzano, Italy

Section: Animal Behavior and Welfare

Keywords: foot pad dermatitis, turkey welfare, sample size, on-farm assessment, indicator, scoring system 


\section{Summary}

Currently, there is no consistent approach to on-farm and post mortem foot pad (FP) assessment in turkey husbandry in sampling of both feet, sample sizes of birds and scoring schemes during the production period. Therefore, in a field study, 11,400 turkeys, i.e., 22,800 feet, were macroscopically scored at 4-week intervals, 60 birds per flock per date, in accordance with the scale system of Hocking et al. (2008). Spearman's rho was calculated between the foot pad dermatitis (FPD) score of both feet of an individual. Sample size for FPD monitoring was calculated for several flock sizes, considering expected FPD prevalence and the error and confidence level $(\alpha=0.01,0.05,0.1)$. To compare macroscopic to histological findings, ten excised FPs were histopathological investigated by hematoxylin \& eosin staining. To align manual macroscopic FPD evaluation with a technical system, 20 photographic images of FPD were measured using the ImageJ program.

The scores of both feet of an individual turkey correlated between $r=0.252$ and $\mathrm{r}=1.000$. Thus, both feet of a bird should be monitored, while the worse foot should be evaluated.

As an exemplary sample size for on-farm FPD assessment, 77 turkey poults were calculated in a flock of 4,000 birds with an expected FPD prevalence of $40 \%$ and $\alpha=0.1$. The sample size of monitored birds within a flock should differ and depend on flock size and expected FPD prevalence.

Histopathological findings showed normal and non-affected structures of a macroscopic Score 0 and a moderate ulcer of the macroscopic Score 1 and Score 2. The applied assessment scheme should distinguish first alterations and scar tissue as separate scores to differentiate the need for management intervention versus the success of management measures that were already implemented.

FPD affected areas were given lower Scores and assessed to be healthier when evaluated by an image system, compared to a manual assessment. Furthermore, with regard to an increase in camera-based assessments, the boundary of the metatarsal pad needs to be clarified.

In conclusion, a new scoring system is required, as the size of the FP cannot be clearly defined and different tissue textures, as well as valid sample sizes are not currently sufficiently considered. 


\section{Introduction}

Foot pad dermatitis (FPD) is one of the major concerns of poultry health and welfare in the European Union (EU, 2017). It has already been proven that management has an influence on foot pad health (Mayne et al., 2007; Abd El-Wahab et al., 2011; Toppel et al., 2017). Therefore, foot pad health could be used as a suitable animalbased indicator for husbandry and environmental conditions. Foot pad health assessment has been specified by the European authorities as an option for broiler welfare assessment and it can be expected for turkeys as well (Hocking et al., 2017).

Several studies have proven a high prevalence of FPD in chickens (De Jong et al., 2012) and in turkey flocks (Spindler, 2007; Krautwald-Junghanns et al., 2011; Allain et al., 2013), including within the rearing period of turkey production (Mayne et al., 2006; Wu and Hocking, 2011; Bergmann et al., 2013; Toppel et al., 2017).

A redness and dark discoloration of scales are often a first indication of foot pad lesions. Additionally, rhagades herald the first signs of degenerative processes on plantar surfaces of foot pads (Kamphues, 2014). These macroscopic findings are followed by hyperkeratosis and necrosis of the epidermis (Martland, 1985). Foot pads were examined microscopically, and inflammatory infiltration was detected on foot pads with macroscopically mild lesions (Michel et al., 2012; Spindler, 2007; Mayne et al., 2006). According to Spindler (2007), it can be assumed that increased macroscopic alterations indicate a deeper lesion. The age of birds must be considered, as in younger turkeys the size of the lesions increases rather than lesion depth as seen in older birds (Youssef et al., 2011; Platt, 2004). FPD can lead to the irritation of sensitive nerve endings in the dermal tissues causing pain, harm, and discomfort (Mayne et al., 2006). Foot pad lesions can completely heal (Mayne et al., 2007; Youssef et al., 2011). According to Platt (2004), scars are visible due to an eliminated scale structure and a pale and even foot pad. The author also stated that week 14 to 21 of life, represents a good healing potential window (Platt 2004). A period of 15 days for healing and scar formation was observed by Mayne et al., (2007).

As an example to use foot pad health as an animalbased indicator for husbandry and environmental conditions, within German turkey production, a benchmark system has been established between batches within a slaughterhouse. The benchmark is based on several animalbased indicators, e.g., foot pad health. Within that system, foot pad 
assessment follows the European 5-point foot pad scoring system from Hocking et al. (2008). The three categories, A, B and C, conform to 0 or 1 (A), 2 and 3 (B) and 4 (C). The latter category should identify conspicuous flocks (Andersson et al., 2015). Several foot pad scoring systems for the turkey species, based on macroscopic (Martland, 1984; Clark et al., 2002; Martrenchar et al., 2002; Mayne et al., 2007; Hocking et al., 2008) and histological (Mayne et al., 2006) findings have been investigated and published in the past. Bergmann et al. (2013) evaluated foot pad health during the rearing period by modifying the scoring systems of Hocking et al. (2008) and Mayne et al. (2007). The assessment schemes show differences, e.g., the number of scales. Furthermore, proposed sample sizes in field studies differed between 50 (Habig et al., 2014; Knierim et al., 2016) and 60 randomly selected birds per flock (Bergmann et al., 2013; Toppel et al., 2017). A difference in expected prevalence was not considered in recommended sample sizes (Knierim et al., 2016), whereas this was calculated for a post mortem evaluation scheme (Hocking et al., 2008).

Alongside manual assessment at the slaughterhouse, a camera system was also established for post mortem evaluation. The system calculates the percentage of an affected black (i.e., necrotic) area on the foot pad (CLK Turkey Check; Westermaier, 2015 ) or the size of a necrotic area, independently from the size of the foot pad (MEYN Foot pad Inspection System; Van Harn and De Jong, 2017). The latter assessment system would offset the lack of an anatomic definition of the foot pad area for macroscopic assessment. Lund et al. (2017) investigated the manual evaluation compared to a camera-based evaluation of broiler foot pads at the slaughterhouse. The assessment was based on a 3-point scale and raters tended to choose the middle score as the most frequent category, whereby results from camera-based evaluation recorded more data in the worst category. Lund et al. (2017) derived that foot pad dermatitis seems to be underestimated.

The increased relevance of FPD scores as measured by future compulsory manual assessments and particularly via automated camera systems requires a consistent approach for on-farm and post mortem foot pad assessment.

This paper aims to address the matters outlined above in three different sections:

Section 1: Foot pad data from a field study were investigated to check and separate the prevalence of no lesions and mild lesions, occurring during the rearing period. The 
dispersion of the affected feet of a single bird were calculated. The necessary sample size for macroscopic foot pad assessment was calculated, considering the expected prevalence, and flock size as well as different levels of confidence, to enable flockspecific actions during the rearing and fattening periods.

Section 2: Macroscopically scored foot pads were compared with histological findings. Section 3: The necrotic area of foot pads was macroscopically calculated by an imaging program to indicate possible differences between technical and manual observations regarding the extent of alterations on the metatarsal pad.

\section{Section 1 - Macroscopic investigations concerning the following issues: FPD prevalence, macroscopic evaluation, number of affected feet of a single bird and sample size of FPD assessment}

\section{Materials and Methods}

\section{Birds and Husbandry}

A field study was conducted on 13 commercial turkey farms, over a 1-year period. Foot pad data from two consecutive production cycles per farm were collected (170,000 toms and 37,000 hens in total). On-farm data were monitored at 4-week intervals in 30 male and seven female flocks on four rearing farms, four fattening farms and five combined farms. On rearing farms, day-old turkey poults were kept until an age of 35 days (rearing period) and then rehoused for the fattening period (day 35 until slaughter). On combined farms, birds remained in the rearing barn during the fattening period. A flock was defined as a group of animals placed in the same barn. The major genetic brand was B.U.T. 6 (31 flocks), followed by B.U.T. 7 (four flocks), and B.U.T. TP7 (two flocks). The average rearing period was $31.2( \pm 3.4)$ days. The fattening period for hens was $113.6( \pm 2.1)$ and $145.8( \pm 3.1)$ days for toms, respectively.

\section{Procedures and Observations:}

The foot pads of 60 randomly selected birds per flock and barn were scored in the 1st, 4 th, 8th, 12th, and 16th week, as well as post mortem in male flocks (only). The plantar area of both foot pads of individual birds were macroscopically scored. During the rearing phase, the foot pad scale of Bergmann et al. (2013) was adopted. The five categories for assessing reared birds were Score $0=$ no alterations on the surface of 
foot pad; Score 1 = hyperkeratosis, moderate hypertrophy of the plantar skin, no dark colored but elongated reticulate scales, Score 2 = severe hyperkeratosis, pronounced hypertrophy of the plantar skin, adhesive dirt cannot be removed without damaging the skin of plantar surface; Score 3 = superficial lesions, epithelial necrosis, darkcolored necrosis of (elongated) reticulate scales; Score $4=$ foot abscess, ablation of the outer layer of the epidermis.

During the fattening period, the 5-point scale of Hocking et al. (1) was used: Score 0 $=$ no external alterations; Score $1=$ harder and denser foot pad with raised center, small necrotic areas, and separated reticulate scales; Score 2 = marked swelling of foot pad, necrotic area covering less than a quarter of foot pad; Score 3 = evident swelling, enlarged foot pad size, pronounced, and separated reticulate scales, necrotic area covering up to half of foot pad; Score $4=$ as Score 3, necrotic area covering more than half of the foot pad. The depth of a lesion was not recorded.

To evaluate the prevalence and severity of FPD, both feet of an individual were monitored and the worst foot (highest score) of a bird was evaluated.

$\underline{\text { Statistical analysis }}$

The inter-observer consistency in farm scoring, between the two observers who monitored foot pad health in this project, was checked before data collection. To do so, 200 pairs of foot pads from 200 turkeys were scored and Kendall's- tau- b was calculated $(\mathrm{r}=0.949 ; \mathrm{p}<0.01)$.

The Spearman's correlation coefficient was calculated by SPSS Vs.24 with a confidence level of 0.95 for the right and left foot of a pair separated by sex, and also for individual flocks.

The sample size was calculated using a standard statistical method for epidemiological studies (Köhler et al., 1995; see also Hocking et al., 2008). The expected prevalence (of foot pad lesions/dermatitis), expected error, and confidence level were considered. The equation is $\mathrm{n}=\left(\mathrm{N}^{*} \mathrm{Z}^{\wedge} 2 * \mathrm{P}(1-\mathrm{P})\right) /\left(\mathrm{d}^{\wedge} 2 *(\mathrm{~N}-1)+\mathrm{Z}^{\wedge} 2 * \mathrm{P}(1-\mathrm{P})\right)$.

The proposed standard was calculated using the formula $n=Z^{2 *} \mathrm{P} *(1-\mathrm{P}) / \mathrm{d}^{2}$, with $\mathrm{n}=$ sample size, $\mathrm{N}=$ flock size (number of birds), $\mathrm{Z}=\mathrm{Z}$-value, $\mathrm{P}=$ Prevalence $(\%$ affected birds of a flock), $\mathrm{d}=\alpha$-error or confidence level. 
The sample sizes for prevalence figures of $10,20,30,40$, and $50 \%$ were calculated, also taking into account an error rate of $0.01,0.05$ and 0.1 with 99, 95, and $90 \%$ confidence for flocks of different sizes with 1,000 - 10,000 birds.

\section{Results}

The results of the evaluation of foot pad health during the rearing and fattening periods, showed major differences between the alterations in the right and left foot of an individual over time. The example of a female flock in Table 9 shows a correlation between both feet of a pair of $r=1.000$ within the first week and $r=0.401$ within the fourth week of life and finally $r=0.252$ at the end of the fattening period. Therefore, high variances within flocks were possible.

Table 9: Correlation between the right and left foot of an individual bird ( $r=b o l d$ values); flocks divided by sex (summarized sample 11,400 pairs from 13 farms $=37$ flocks)

\begin{tabular}{|c|c|c|c|c|c|c|}
\hline \multirow[t]{2}{*}{ Determinants } & \multicolumn{6}{|c|}{ Week of Life } \\
\hline & 1 & 4 & 8 & 12 & 16 & p.m. \\
\hline male (wc) & $\begin{array}{r}\mathbf{0 . 6 9 1} \\
450\end{array}$ & $\begin{array}{r}\mathbf{0 . 7 3 0} \\
600\end{array}$ & $\begin{array}{r}\mathbf{0 . 3 5 5} \\
600\end{array}$ & $\begin{array}{r}\mathbf{0 . 6 4 4} \\
810\end{array}$ & $\begin{array}{r}\mathbf{0 . 6 6 4} \\
840\end{array}$ & $\begin{array}{l}\mathbf{0 . 5 6 6} \\
\\
840\end{array}$ \\
\hline male (sc) & $\begin{array}{r}\mathbf{0 . 6 7 7} \\
600\end{array}$ & $\begin{array}{r}\mathbf{0 . 6 6 7} \\
660\end{array}$ & $\begin{array}{r}\mathbf{0 . 5 2 2} \\
960\end{array}$ & $\begin{array}{r}\mathbf{0 . 4 7 3} \\
960\end{array}$ & $\begin{array}{r}\mathbf{0 . 6 2 1} \\
960\end{array}$ & $\begin{array}{l}\mathbf{0 . 5 0 2} \\
\quad 1170\end{array}$ \\
\hline female (wc) & $\begin{array}{r}\mathbf{0 . 7 4 1} \\
210\end{array}$ & $\begin{array}{r}\mathbf{0 . 5 5 0} \\
240\end{array}$ & $\begin{array}{r}\mathbf{0 . 3 6 4} \\
240\end{array}$ & $\begin{array}{r}\mathbf{0 . 6 8 6} \\
240\end{array}$ & $\begin{array}{r}\mathbf{0 . 5 4 8} \\
240\end{array}$ & No evaluation \\
\hline female (sc) & $\begin{array}{r}\mathbf{1 . 0 0 0} \\
120\end{array}$ & $\begin{array}{r}\mathbf{0 . 3 5 7} \\
180\end{array}$ & $\begin{array}{r}\mathbf{0 . 3 9 8} \\
180\end{array}$ & $\begin{array}{r}\mathbf{0 . 5 2 0} \\
180\end{array}$ & $\begin{array}{r}\mathbf{0 . 5 2 6} \\
120\end{array}$ & No evaluation \\
\hline $\begin{array}{l}\text { sample- } \\
\text { single male flock }\end{array}$ & $\begin{array}{r}0.615 \\
60\end{array}$ & $\begin{array}{r}0.790 \\
60\end{array}$ & $\begin{array}{r}\mathbf{0 . 6 9 3} \\
\\
120\end{array}$ & $\begin{array}{r}0.679 \\
\\
180\end{array}$ & $\begin{array}{r}\mathbf{0 . 3 8 3} \\
180\end{array}$ & $\begin{array}{r}\mathbf{0 . 5 3 1} \\
\\
\\
180\end{array}$ \\
\hline $\begin{array}{l}\text { sample- } \\
\text { single female flock }\end{array}$ & $\begin{array}{r}1.000 \\
60\end{array}$ & $\begin{array}{r}0.401 \\
60\end{array}$ & $\begin{array}{r}0.323 \\
60\end{array}$ & 0.562 & $\begin{array}{r}0.252 \\
60\end{array}$ & No evaluation \\
\hline
\end{tabular}

Figure 4 shows the distribution of foot pad scoring between the left and right foot of an individual, in particular with regard to Score 0 and Score 1 . The evaluations were performed in the 1st, 4th, and 8th weeks of life. Within the first week, $63.5 \%$ of the pairs were scored without any lesions on the left and right foot (0/0). Inversely, in 35\% 
of the pairs of foot pads evaluated, at least one foot differed from Score 0 (0/1, i.e., one of the two feet of an individual showed FPD Score 1 and one no FPD; $1 / 1$ both feet with FPD Score $1 ;>0 / 1,1 / 1$ means at least one foot of an individual worse than Score 1). The proportion of pairs without any alterations decreased to $45.7 \%$ by week 4 and to $0.1 \%$ in week 8 . Pairs of feet with a FPD Score $>0 / 1,1 / 1$ were proportionally the highest in week 8 with $53.0 \%$.

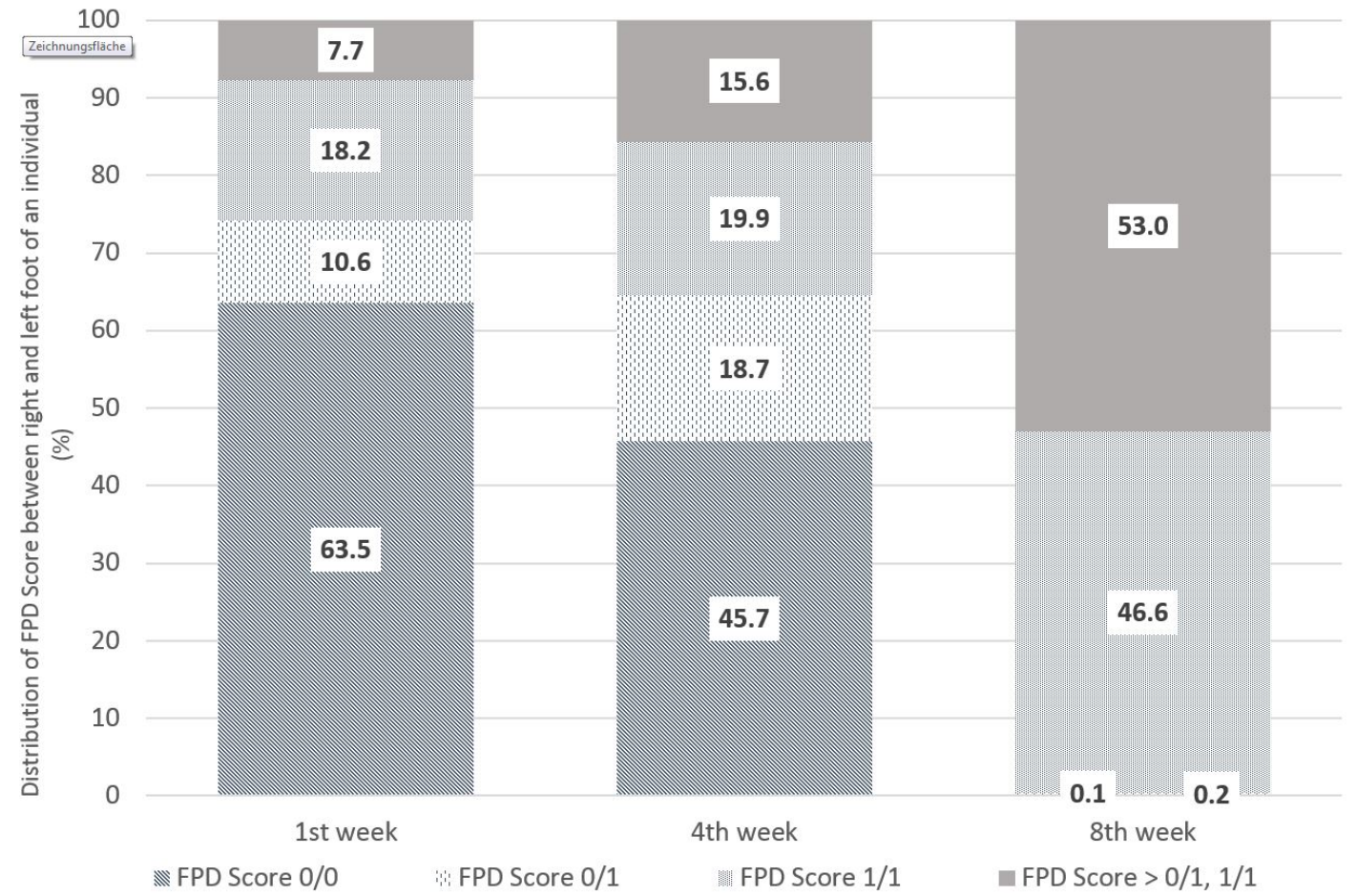

Figure 4: Comparison of FPD-Scores between the right and left foot of an individual bird from the first to eighth week in \% ( $n=1,382$ pairs (1st week), 1,681 pairs (4th week), 2,013 pairs (8th week)) (where Score '0/0 means no FPD on left and right foot; 0/1 one foot of the pair with FPD Score 1 and the other Score 0, 1/1 both feet with FPD Score 1 and $>0 / 1 ; 1 / 1$ stands for at least one foot of an individual worse than Score 1).

To estimate foot pad health within a flock, the sample size for monitoring was calculated. Suggested sample sizes increased with the level of confidence, as shown in Table 10. A symmetrical calculation with an identical sample size leads to a prevalence of $90,80,70$, and $60 \%$, which is equal to $10,20,30$, and $40 \%$ (non-) affected birds, respectively [cf. Hocking et al. 2008]. As an example, the monitoring of the status quo of FPD in a flock of 4,000 birds per barn unit, requires a sample size of 77 birds if the expected FPD prevalence is about $40 \%$ (or vice versa $60 \%$ non-affected birds) during rearing with a confidence level of $95 \%$. The expected value would be adjusted to the 
data of evaluation in Table 10. Furthermore, a higher expected FPD prevalence during fattening would require a smaller sample size for FPD monitoring. An expected prevalence of $90 \%$ would require assessment of a total of 29 birds. A higher confidence interval of $99 \%$ would be realized by a higher sample number.

Table 10: Calculated number of birds to be monitored and evaluated depending on flock size, prevalence of footpad alterations, confidence interval $(\alpha 0.1=90 \%, 0.05=$ $95 \%$, and $0.01=99 \%$, respectively) and proposed standard.

\begin{tabular}{|c|c|c|c|c|c|c|c|c|c|c|c|c|}
\hline \multirow{2}{*}{$\begin{array}{l}\alpha \text { of FPD } \\
\text { expected } \\
\text { frequency }\end{array}$} & \multirow{2}{*}{$\begin{array}{c}\text { FPD } \\
\text { expected } \\
\text { frequency } \\
(\%)\end{array}$} & \multicolumn{10}{|c|}{ Flock size } & \multirow{2}{*}{$\begin{array}{c}\text { Pro- } \\
\text { posed } \\
\text { Standard }\end{array}$} \\
\hline & & 1000 & 2000 & 3000 & 4000 & 5000 & 6000 & 7000 & 8000 & 9000 & 10000 & \\
\hline 0.1 & 10 & 29 & 29 & 29 & 29 & 29 & 29 & 29 & 29 & 29 & 29 & 30 \\
\hline 0.1 & 20 & 50 & 51 & 52 & 52 & 52 & 52 & 52 & 52 & 52 & 52 & 52 \\
\hline 0.1 & 30 & 65 & 67 & 67 & 68 & 68 & 68 & 68 & 68 & 68 & 68 & 69 \\
\hline 0.1 & 40 & 68 & 73 & 76 & 77 & 77 & 78 & 78 & 78 & 78 & 78 & 79 \\
\hline 0.1 & 50 & 76 & 79 & 80 & 80 & 81 & 81 & 81 & 81 & 81 & 81 & 82 \\
\hline 0.05 & 10 & 124 & 132 & 135 & 136 & 137 & 138 & 138 & 139 & 139 & 139 & 141 \\
\hline 0.05 & 20 & 201 & 223 & 232 & 236 & 239 & 241 & 242 & 243 & 244 & 245 & 251 \\
\hline 0.05 & 30 & 248 & 283 & 297 & 304 & 309 & 312 & 315 & 316 & 318 & 319 & 329 \\
\hline 0.05 & 40 & 274 & 317 & 334 & 344 & 350 & 354 & 357 & 359 & 361 & 363 & 376 \\
\hline 0.05 & 50 & 282 & 328 & 347 & 357 & 364 & 368 & 371 & 374 & 376 & 377 & 392 \\
\hline 0.01 & 10 & 823 & 1398 & 1823 & 2149 & 2408 & 2618 & 2792 & 2939 & 3064 & 3171 & 4644 \\
\hline 0.01 & 20 & 892 & 1610 & 2201 & 2695 & 3114 & 3475 & 3788 & 4063 & 4306 & 4523 & 8256 \\
\hline 0.01 & 30 & 916 & 1689 & 2350 & 2922 & 3422 & 3862 & 4253 & 4602 & 4917 & 5201 & 10836 \\
\hline 0.01 & 40 & 925 & 1722 & 2415 & 3024 & 3562 & 4042 & 4472 & 4861 & 5212 & 5533 & 12384 \\
\hline 0.01 & 50 & 928 & 1732 & 2434 & 3053 & 3604 & 4095 & 4538 & 4938 & 5302 & 5633 & 12900 \\
\hline
\end{tabular}




\section{Discussion}

The results during rearing show a correlation coefficient between the right and left foot of an individual equal to or less than $\mathrm{r}=0.790$. Other authors achieved results of $\mathrm{r}=0.830$ (Spearman's rank correlation coefficient; 11,830 pairs) (KrautwaldJunghanns et al. 2011) and $r=0.835$ (Spearman) (Bergmann et al., 2013). Based on the study of Krautwald-Junghanns et al. (2011), Allain et al. (2013) evaluated only the right foot of an individual in their study. This method was also applied in the study by Bergmann et al. (2013). However, in consideration of the welfare of an individual, and by using a small sample size, more precision can be achieved by monitoring both feet of a single turkey and evaluating the ones classified as being most severe during an on-farm evaluation. This conclusion was also reached by Hocking et al. (2017), as they only evaluated the worst foot pads in their study, which is also recommended by Knierim et al. (2016).

The first alterations on metatarsal pads were observed within 7 days post hatching. These findings are comparable to those of Bergmann et al. (2013). The present results show the necessity for early monitoring and evaluation during the rearing period, as well as the use of a scoring system allowing the evaluation of first alterations separate from non-affected feet or no lesions (Score 0). This is in contrast to recommendations for a self-monitoring system by Knierim et al. (2016). The latter authors suggest an assessment during the fifth week of age, based on a scheme which includes no lesions and small necrotic areas within the same scoring category. In this context, evaluating the foot pad with the highest score (worst performance; c.f. Bergmann et al., 2013; Knierim et al., 2016) would reflect the realistic situation of the flock.

The calculation of the sample size was conducted in accordance with Hocking et al. (2008). The authors calculated a prevalence of FPD beginning with necrotic areas in accordance with Score 2 (necrotic area up to a quarter of the foot pad) on the 5-point scale at slaughter. In contrast to that scheme, on-farm monitoring should consider all lesion formations in order to signal the beginning of FPD and also the development of foot pad alterations. The sample size used might be a compromise between estimating FPD prevalence and the economic feasibility of monitoring as well as minimizing stress for the birds caused by handling and lifting the individuals. To meet the latter needs and to benefit from on-farm monitoring, it is probably most realistic to assess 
on the basis of a $90 \%$ confidence level. Additionally, references of FPD prevalence are available from former flocks (Toppel and Andersson, 2016). Moreover, camerabased assessment of foot pad health is increasing and allows a much higher sample size post mortem. De Jong (2013) described $96.2 \%$ of feet being assessed daily at a broiler slaughter-house via the Meyn Foot Pad Inspection System. Depending on the technical precision and accuracy of the assessment method at slaughter, as well as the large sample size, a monitoring system based on one foot of an individual is deemed to be most suitable.

\section{Section 2 - Histological investigations to assess depth of macroscopic lesions}

\section{Materials and Methods}

A total of 30 feet from male turkeys at the end of fattening (21st week of life) were first scored macroscopically and then a histopathological investigation of ten excised foot pads (macroscopically scores 0 to 4 and a bumble foot) was performed. This method required tissue from the center of the metatarsal pad to be removed and fixed in formic acid (10\%) for 24 hours for histological examination. Afterwards, slices were constructed with a standard microtome of about $5 \mu \mathrm{m}$ and were stained with hematoxylin/eosin (HE). After processing, the histological samples were examined under a light microscope with an evaluation of the histopathological characteristics of the epidermis (Stratum corneum and Stratum profundum) and dermis (Corium) based on the arrangement of the scales [carried out by LAVES, Oldenburg, in accordance with Mayne et al. (2007) and Spindler (2007)]. Characteristics of lesions were separated according to occurrence and severity of slight, moderate or severe hyperkeratosis, erosion and ulceration. A further parameter was indicative of an inflammatory process, proven by an infiltration of granulocytes and the presence of bacteria.

\section{Results}

A sample of six macroscopically different foot pads with histopathological findings is presented in Table 11 and $11 \mathrm{ff}$. 
Table 11: Examples of macroscopic and histological observations of foot pads with different levels of foot pad lesions.

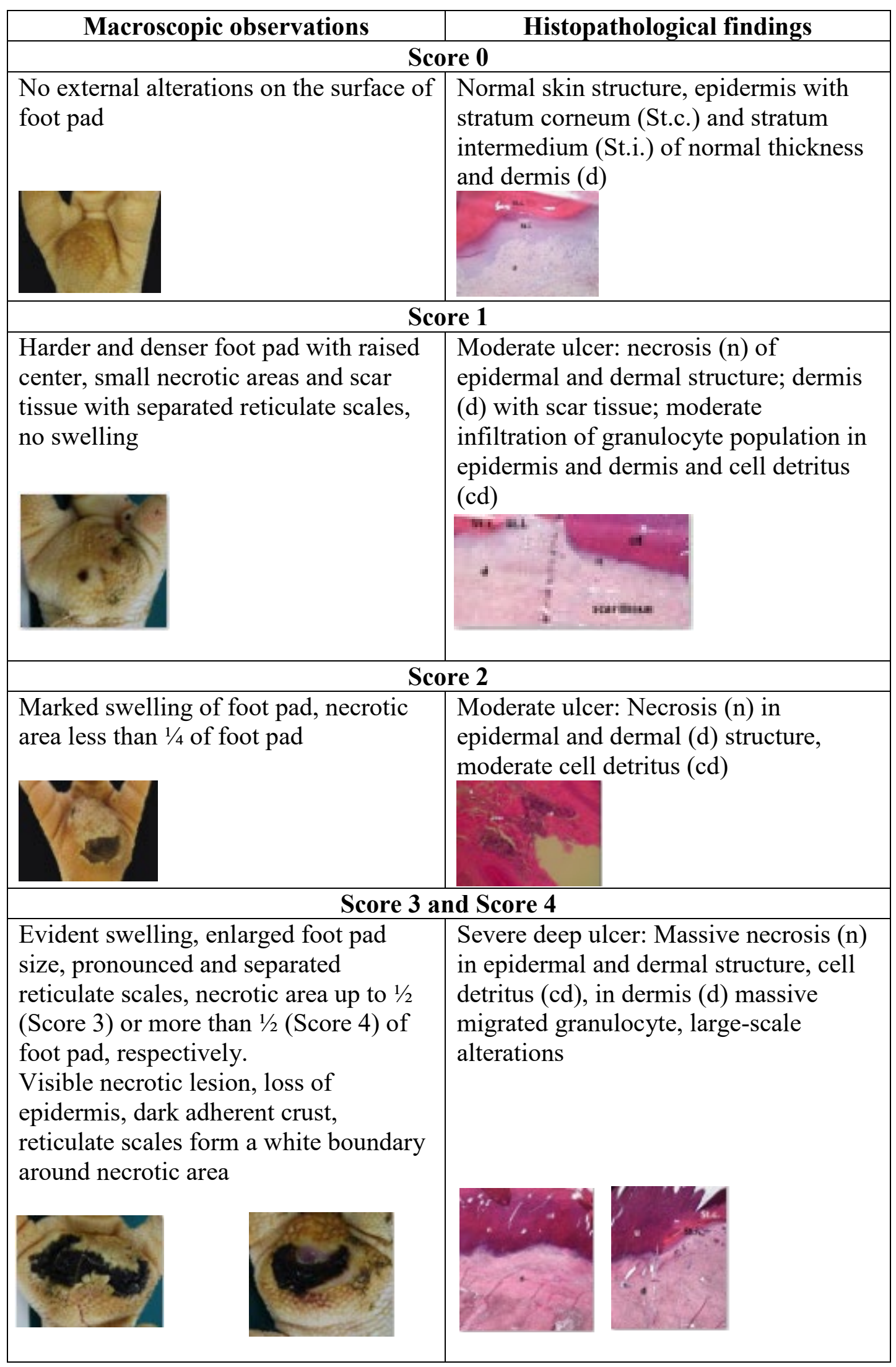


Table 11ff: Examples of macroscopic and histological observations of foot pads with different levels of foot pad lesions.

\begin{tabular}{|c|c|}
\hline Macroscopic observations & Histopathological findings \\
\hline \multicolumn{2}{|c|}{ Bumble Foot } \\
\hline $\begin{array}{l}\text { Swollen enlarged foot pad, necrotic } \\
\text { area }<1 / 2 \text { of the foot pad due to } \\
\text { swelling }\end{array}$ & $\begin{array}{l}\text { Abscess, swollen collagen structure, } \\
\text { clearly visible massive bacterial } \\
\text { colonies in dermal structure }\end{array}$ \\
\hline
\end{tabular}

At the macroscopic foot pad Score 0 with no visual findings, a slight hyperkeratosis, characterized by an extension of the Stratum corneum, and the extension of the scales were discernible. At the macroscopic foot pad lesion Score 1 with no swelling, a slightly rough scale structure, scar tissue and a small necrotic area of metatarsal pad, were already present. The following Scores 2-4 resulted in a larger extension of the histopathological findings; for example, the size of the ulcerated area due to an inflammatory process. This macroscopic scoring indicated a large necrosis on the plantar area. This was covered by a dark adherent crust and showed a white boundary of reticulate scales around the necrosis.

The most affected foot displayed a swollen and enlarged foot pad, so-called bumble foot, whereby a necrosis was formed with a surface rigid to the touch. Histological findings showed a prominent abscess and a swollen collagen structure. Strong bacterial colonies were also detected.

\section{Discussion}

The macroscopic scoring of the foot pad Score 1 showed a covering of a slightly rough scale structure. The development of the scale-shaped structure requires an intact dermal structure (Platt 2004). The existence of a macroscopically small, affected, darkcolored area (Score 1) was proven histopathological to herald the presence of an ulcer, where the epidermis and dermis were affected, and inflammatory tissue was present. Typically, cell detritus and necrosis developed under the plantar surface. Additionally, a granulocyte population was detected in the epidermis and dermis indicating inflammatory processes, in agreement with Spindler (2007). This is also in accordance 
with studies performed on broilers, for example, Greene et al. (1985), where the development of a severe ulcer in broiler foot pads within $<1$ week on a previously intact plantar surface was described. Heitmann et al. (2018) also found ulcerations in a broiler foot pad which received a low score macroscopically. When taking up the assessments of Hocking et al. (2017) and Spindler (2007), it can be assumed that increased macroscopic alterations indicate a deeper lesion. Therefore, detecting first lesions separate from Score 0 , is essential for implementing timely measures, in particular considering animal welfare.

In the case of ulcers and deep lesions, the affected dermis and epidermis can also recover. A white area is clearly visible on the surface and indicates scar tissue, which develops instead of reticulate scales (Rudolf, 2008; Platt, 2004). Platt (2004) described evidence of scar tissue at the end of the fattening period in most of the bird's foot pads in her study. A swollen and enlarged foot pad, so-called bumble foot, is formed by a prominent abscess and swollen collagen structure. The histological results correlated with the macroscopic findings. Bumble foot was described as causing pain, limited mobility and reduced water consumption (Wilcox et al., 2009).

However, injured foot pads do not necessarily lead to deficiencies in gait and activity and therefore may not be used to indicate the presence of a foot pad problem (Krautwald-Junghanns et al., 2011). This emphasizes the necessity for the on-farm monitoring of foot pad health by picking out single birds and looking at the feet.

\section{Section 3 - Comparison between camera-based macroscopic assessment and manual evaluation}

\section{Material and Methods}

The camera system used in German turkey slaughterhouses, which calculates the proportion of a necrotic area in relation to the estimated area of the metatarsal pad [CLK - Cruse Lappel-mann Kognitionstechnik, Altenberge, cf. Westermaier, 2015], was evaluated in this study. To examine the optical illusion of altered (=necrotic) areas on metatarsal pads, human subjective evaluation was compared to a technical solution. Twenty randomly selected pictures from turkey foot pads and digits were analyzed. Foot pads had either identifiable, macroscopic necrosis on the plantar surface of the foot pad or digit or showed visible scar tissue. For estimating the surface ratio, the 
image processing system ImageJ 1.51k (Vs.64bit, Bethesda, USA) was used. A certain area was marked and represented in a number of pixels (cf. Figure 5). Visible alterations on turkey foot pad photographic images were tagged freehand, analyzed and measured by the program. The dimensions of alterations were categorized according to the scheme of Hocking et al. (2008) [see Material and Methods Section 1]. Finally, information for herd managers was derived, depending on the evaluation at the slaughterhouse or the on-farm monitoring.

\section{Statistical analysis}

Each photographic image was measured with three replications. The coefficient of variation $(\mathrm{CV})$ was calculated for every boundary (green, red and blue area) by SPSS Vs.24. The equation was $\mathrm{CV}=\mathrm{s} / \overline{\mathrm{x}}$, while $\mathrm{s}=$ standard deviation and $\overline{\mathrm{x}}$ is sample mean.

\section{Results}

Figure 5 shows representations of different altered areas which were presented. It might be assumed that a human observer would tend to give a higher or worse assessment, especially considering the picture on the left, compared to the technical value of $48.6 \%$ red area. In accordance with Hocking et al. (2008), the photographic image on the left would be categorized as being equivalent to Score 3 .

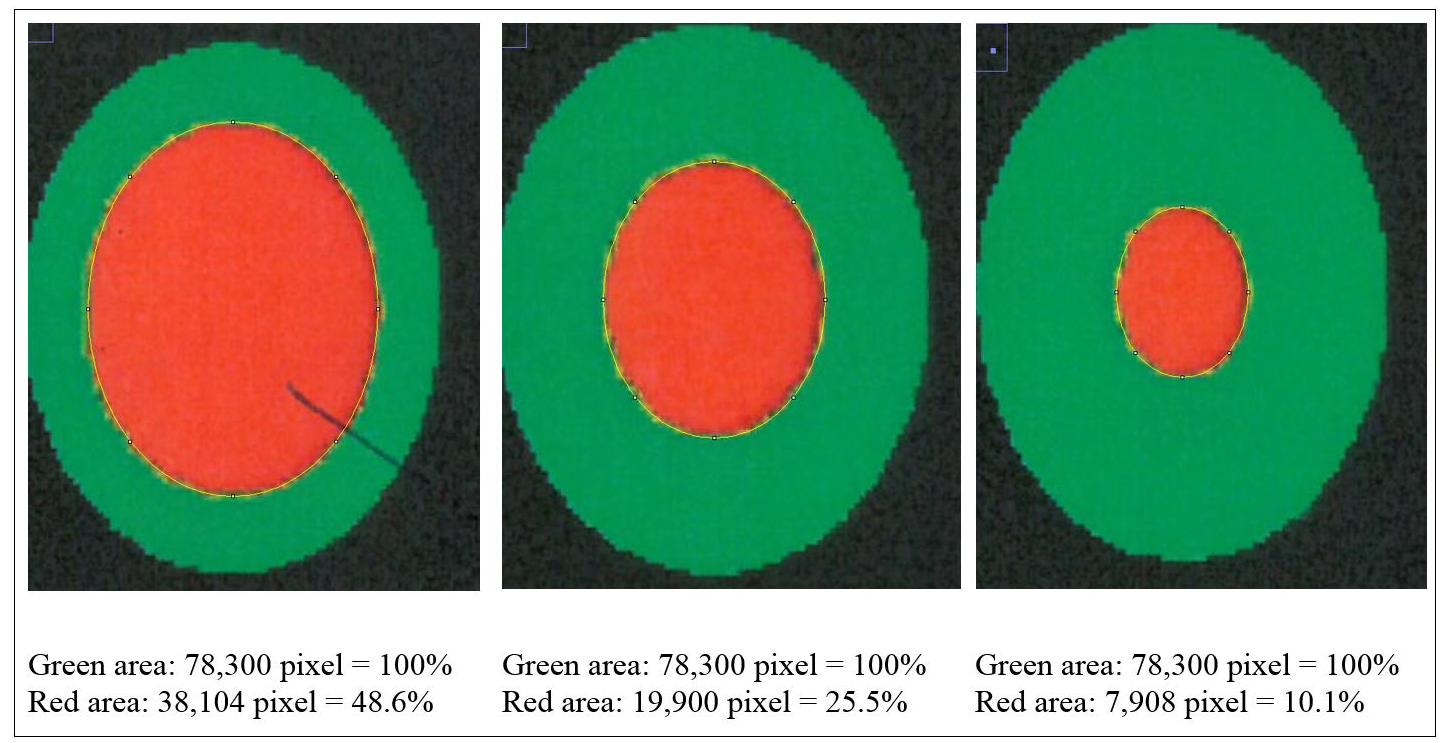

Figure 5: Surface ratio green $=$ foot pad, red $=$ necrosis, fine yellow frame presents manually marked area; output number of pixels by ImageJ $1.51 \mathrm{k}$. 
Several foot pad alterations were quantified in proportion to the foot pads area. The results are presented in Table 12. The first picture was obtained from the official European foot pad scoring system for turkeys in meat processing plants (Hocking et al., 2008). The calculated area of a foot pad was given a green boundary, the red border marked the necrotic or black area. In accordance with Hocking et al. (2008), the photographic image corresponds to Score 4, which is described with a necrotic area covering over $50 \%$ of the foot pad. Considering the presented assumption of foot pad area, it resulted in a $25.1 \%$ necrotic area, which is equivalent to Scores 2 or 3 on a camera-based evaluation at the slaughterhouse.

The foot in the second photographic image was subjectively classified as being affected by a huge necrotic area. The red area was calculated by the image program to have an altered sur-face area of $37.2 \%$. That would correspond to a camera-based Score 3 when following the Hocking System (Score 0 - no lesions to Score 4 - necrotic lesions $>50 \%$ of foot pad) after slaughtering (Hocking et al., 2008). Again, threedimensionality was not taken into account. The third and fourth photographic images show the formation of scar tissue over an area calculated to be $52.2 \%$ and $35.6 \%$ of the foot pad, respectively. 
Table 12: Calculation and description of macroscopic foot pad alterations (green line: $100 \%$ metatarsal pad; red line: detected necrotic (black) area; blue line: scars; three samples/figure; mean value (pixel) and coefficient of variation (CV)).

\begin{tabular}{|c|c|c|c|}
\hline \multirow[t]{2}{*}{ No. } & Calculation & \multicolumn{2}{|c|}{$\begin{array}{l}\text { Assumed derived information to herd } \\
\text { manager }\end{array}$} \\
\hline & & $\begin{array}{c}\text { Camera-based assessment } \\
\text { (p.m.) }\end{array}$ & \begin{tabular}{|c|} 
Manual \\
assessment \\
on-farm \\
\end{tabular} \\
\hline 1 & $\begin{array}{l}\text { Green line: } \\
\text { 226953.3 Pixel } \\
\text { (CV 0.002) } \\
\text { red line: } \\
\text { 57076.7 Pixel } \\
\text { (CV 0.004) } \\
=25.1 \%\end{array}$ & $\begin{array}{l}\text { Camera-based result } \\
\text { - Score " } 2 \text { " or " } 3 \text { " } \\
\text { - Considering Hocking: Score } \\
2 \text { necrosis up to } 25 \% \text { of foot } \\
\text { pad, Score } 3 \text { necrosis between } \\
25 \text { to } 50 \% \text { of foot pad. } \\
\text { - Original scheme classified } \\
\text { Score "4" (more than } 50 \% \\
\text { necrotic area). }\end{array}$ & $\begin{array}{l}\text { - Major problem } \\
\text { in flock. } \\
\text { - Measures are } \\
\text { necessary } \\
\text { immediately. }\end{array}$ \\
\hline 2 & $\begin{array}{l}\text { Green line: } \\
3556313 \text { Pixel } \\
\text { (CV 0.002) } \\
\text { red line: } \\
1322907 \text { Pixel } \\
(\mathrm{CV} 0.001) \\
=37.2 \%\end{array}$ & $\begin{array}{l}\text { Camera-based result } \\
\text { - Score "3". }\end{array}$ & $\begin{array}{l}\text { - Major problem } \\
\text { in flock. } \\
\text { - Measures are } \\
\text { necessary } \\
\text { immediately. }\end{array}$ \\
\hline 3 & $\begin{array}{l}\text { Green line: } \\
2038920 \text { Pixel } \\
\text { (CV 0.000) } \\
\text { blue line: } \\
\text { 1063746 Pixel } \\
\text { (CV 0.002) } \\
=52.2 \%\end{array}$ & $\begin{array}{l}\text { Camera-based result } \\
\text { - Score "0". } \\
\text { Even though white scar tissue } \\
\text { is present, that only provides } \\
\text { information of an older, } \\
\text { partly healed process. } \\
\text { Lost information p.m. } \\
\text { - Problems during housing } \\
\text { - Successful measure to } \\
\text { improve foot pad health. }\end{array}$ & $\begin{array}{l}\text { - There was a } \\
\text { problem in } \\
\text { stock, bedding } \\
\text { material/ litter } \\
\text { moisture. } \\
\text { - Successful } \\
\text { measure } \\
\text { improved foot } \\
\text { pad health. }\end{array}$ \\
\hline 4 & $\begin{array}{l}\text { Green line: } \\
1102192 \text { Pixel } \\
\text { (CV 0.004) } \\
\text { red line: } \\
24500 \text { Pixel } \\
\text { (CV } 0.000) \\
=2.2 \% \\
\text { blue line: } \\
416407 \text { Pixel } \\
\text { (CV } 0.002) \\
=35.6 \%\end{array}$ & $\begin{array}{l}\text { Camera-based result } \\
\text { - Score " } 1 \text { ". } \\
\text { Even though white scar tissue } \\
\text { is present, that only provides } \\
\text { information of an older, } \\
\text { partly healed process } \\
\text { Lost information p.m. } \\
\text { - Problems during housing } \\
\text { - Successful measure to } \\
\text { improve foot pad health. }\end{array}$ & $\begin{array}{l}\text { - Severe lesions } \\
\text { on digital pads. } \\
\text { - Lessen } \\
\text { necrosis. } \\
\text { - Scar tissue on } \\
\text { metatarsal pad. }\end{array}$ \\
\hline
\end{tabular}




\section{Discussion}

Several foot pad alterations were quantified in proportion to the perceived foot pad area of the metatarsal pad. This highlights the lack of an anatomic and macroscopic definition of the metatarsal pad. The size is not clear and obviously too large in relation to the necrotic area. Furthermore, the method used does not consider threedimensionality, which would probably lead to an increase in the proportion of the nonaffected area. The optical illusion becomes clear in the second photographic image (No. 2). Based on manual assessment, the necrotic area would probably be within the range equal to Score 4, while the result from camera-based assessment would diminish FPD severity to a computer-based Score 3. On-farm foot pad assessment enables the immediate implementation of management measures. Therefore, further discussion is probably required concerning the percentage of the necrotic area which categorizes a foot pad with severe lesions ( $>50 \%)$ which, in accordance with health programs, could have consequences for obviously high-risk turkey farms. Furthermore, Mayne et al. (2007) and Youssef et al. (2011) discovered visible cellular changes on foot pads after continuous exposure to wet litter over a period of 48 or 8 hours per day. The process of healing took about 15 days when young turkeys were transferred from wet $(26 \%$ dry matter content) to dry litter (87\% dry matter content) (Mayne et al., 2007). Suitable litter material, other than straw, could be sawdust or wood shavings which seem to result in less caked litter. However, a coarse litter material structure must also be considered (Hester et al., 1997; Mayne et al., 2007; Kamphues, 2014). Rudolf (2008) observed the correlation between litter material and the formation of scar tissue. Toms and hens which were kept on wood shavings showed a higher formation of scar tissue on metatarsal pads, compared to birds which were kept on unchopped straw. Additionally, Platt (2004) found that the highest prevalence of scar tissue was observed between the $14^{\text {th }}$ and $21^{\text {st }}$ week of life, during on-farm assessment. When taking these results into consideration, they suggest the necessity of monitoring first alterations as well as scar formation on foot pads. Due to the importance of management measures with a focus on dry litter material, quick and prompt action is needed in order to combat prevention of severe foot pad lesions and receive feedback on successful management. Camera-based analysis focusing on the size of the necrotic area currently takes neither alteration on digits, nor scar tissue into account. This information would be important 
to inform any need for management measures in subsequent flocks. This would not only increase the importance of on-farm foot pad assessment but also require a scoring system which categorizes scar formation and digits separately from lesions of the metatarsal pad.

\section{Overall conclusions}

In conclusion, an on-farm foot pad scoring system is necessary to improve foot pad health in turkey husbandry. A 4-week evaluation interval would match the time for formation of scar tissue and allow for reflection on the success and necessity of management measures. To increase welfare levels on farms, both bird feet should be monitored, and the most affected foot should be evaluated. The scoring system used should consider first alterations separately from non-affected feet, as well as digital pads from metatarsal pads and also the formation of scar tissue. Further studies are also required to fill the gap on the boundary of the metatarsal pad and the histopathological findings. Finally, the applied scoring system would require a more detailed scale, especially up to $50 \%$ macroscopic alterations on the plantar foot pad. An important issue, necessary for the improvement of FPD assessment validity, is an external standard that supports the comparability of foot pad results. Implementing this statement on the recovery rate would enable a comparison to be made between foot pad findings from manual and automatic assessments (Petermann et al., 2017).

\section{Acknowledgement}

A special thanks to Dr. Michael Bruegman from the Lower Saxony State Office for Consumer Protection and Food Safety (LAVES), Oldenburg, Germany, for the preparation and execution of histological sections. We also wish to thank the Lower Saxony Ministry of Food, Agriculture and Consumer Protection, and the Ministry of Science and Culture of Lower Saxony. Furthermore, we would like to thank Dr. Lucy Waldron and Dr. Paul Hocking for their kind permission to reproduce the Score 4 from the Hocking Scheme (Hocking et al. 2008, World's Poultry Sci J, 64:325).

\section{Data availability statement}

The raw data supporting the conclusions of this manuscript will be made available by the authors, without undue reservation, to any qualified researcher. 


\section{Ethics Statement}

The study was carried out in accordance with the German legislations, the German Animal Protection Act (TierSchG, 2017), the 'National reference figures for a voluntary agreement on keeping fattening turkeys' (VDP, 2013) and national requirements for animal husbandry (TierSchNutztV, 2016) as well as the 'Guide for the Care and Use of Agricultural Animals in research and Teaching' (Ag Guide 2010). Data from Section 1 were collected within a project from the 'Animal Welfare Plan of Lower Saxony' (Petermann et al., 2017). The studies were supported and monitored by officials from the Lower Saxony Ministry of Food, Agriculture and Consumer Protection and the Lower Saxony State Office for Consumer Protection and Food Safety (LAVES). Turkey feet for Section 3 were collected after a commercial slaughtering process at a German slaughterhouse.

\section{Author Contributions Statement}

$\mathrm{KT}$, BS and RA conceived the study. KT and BS processed the experimental data, performed the analysis and designed the figures in Sections 1 and 3. BS and NK prepared and executed parts of the histopathological section. MG and RA provided support and advice. KT wrote the manuscript in consultation with BS, FK, MG, NK, and RA. All the authors contributed to the revision of the manuscript and approved the final version of the manuscript for submission.

\section{Conflict of interest}

The authors declare that the research was conducted in the absence of any commercial or financial relationships that could be construed as a potential conflict of interest.

\section{References}

Abd El-Wahab, A., Beineke, A., Beyerbach, M., Visscher, C.F., and Kamphues, J. (2011): Effects of Floor Heating and Litter Quality on the Development and Severity of Foot Pad Dermatitis in Young Turkeys. Avian Dis. 55, 429-434. doi: 10.1637/9684021011-Reg.1.

Ag Guide (2010). Guide for the Care and Use of Agricultural Animals in Research and Teaching. 3rd edition. Federation of Animal Science Societies. Chapter 9: Poultry. 103-128. Available online http://www.poultryscience.org/docs/agguide/AG_Guide_3rdEd.pdf.

Allain, V., Huonnic, D., Rouina, M., and Michel, V. (2013): Prevalence of skin lesions in turkeys at slaughter. Brit. Poultry Sci. 54:33-41. doi: 10.1080/00071668.2013.764397. 
Andersson, R., Toppel, K. and Heesen, S. (2015): Measuring Animal Welfare. Initial experiences with turkey health and welfare indicators. In: K. Damme and F. Muth (ed.) Gefluegeljahrbuch 2016. Schwerpunkt Tierwohl. Stuttgart: Eugen Ulmer, 24-32.

Bergmann, S., Ziegler, N., Bartels, T., Hübel, J., Schumacher, C., Rauch, E., Brandl, S., Bender, A., Casalicchio, G., Krautwald-Junghanns, M.-E., and Erhard, M.H. (2013): Prevalence and severity of foot pad alterations in German turkey poults during the early rearing phase. Poultry Sci. 92:1171-1176. doi: 10.3382/ps.2012-02851.

Clark, S., Hansen, G., McLean, P., Bond Jr., P., Wakeman, W., Meadows, R., et al. (2002): Pododermatitis in Turkeys. Avian Dis. 46, 1038-1044. doi: 10.1637/0005-

2086(2002)046[1038:PIT]2.0.CO;2.

De Jong, I.C. (2013): Evaluation Meyn Footpad Inspection System. Wageningen UR Live-stock Research: Report 713. http://edepot.wur.nl/285836 (accessed 2 January 2018).

De Jong, I. C., van Harn, J., Gunnink, H., Hindle, V. A. and Lourens, A. (2012): Footpad dermatitis in Dutch broiler flocks: Prevalence and factors of influence. Poultry Sci. 91:1569-1574. doi: 10.3382/ps.2012-02156.

EU (2017): Use of Slaughterhouse Data to Monitor Welfare of Broilers on Farm. Overview report. Directorate for Health and Food Audits and Analysis. European Union (EU). Available at https://publications.europa.eu/en/publication-detail//publication/9fbf913d-de15-11e6-ad7c-01aa75ed71a1/language-en/ format-PDF. DOI 10.2772/57892 (accessed January 2, 2018).

Greene, J. A., McCracken, R. M. and Evans, R. T. (1985): A contact dermatitis of broilers-clinical and pathological findings. Avian Pathol. 14:23-38. doi: 10.1080/03079458508436205.

Habig, C., Spindler, B., Berk, J., Hartung, J. and Kemper, N. (2014): Evaluation of foot pad health in turkeys kept under organic husbandry conditions. Proceedings of 10th "Hafez" International Symposium on Turkey Diseases. 2014 June 5-7; Berlin, Germany. Berlin: Mensch und Buch Verlag (2002). 15-21.

Heitmann, S., Stracke, J., Petersen, H., Spindler, B. and Kemper, N. (2018): First approach validating a scoring system for foot-pad dermatitis in broiler chickens developed for application in practice. Prev. Vet. Med. 154:63-70. doi: 10.1016/j.prevetmed.2018.03.013.

Hester, P.Y., Cassens, D.L. and Bryan, T.A. (1997): The applicability of particleboard residue as a litter material for male turkeys. Poultry Sci. 76:248-255. doi: 10.1093/ps/76.2.248.

Hocking, P. M., Harkness, A., Veldkamp, T. and Vinco, L. J. (2017): Do foot pad scores measure turkey welfare? In: Turkeytimes, editor. Proceedings of the $11^{\text {th }}$ Turkey Science and Production Conference. 2017 March 9-10; Chester, UK. 20-23.

Hocking, P. M., Mayne, R. K., Else, R. W., French, N. A. and Gatcliffe, J. (2008): Standard European footpad dermatitis scoring system for use in turkey processing plants. World Poultry Sci. J. 64:323-328. doi: 10.1017/S0043933908000068. 
Kamphues, J. (2014): Zur Bedeutung von Fütterung und Haltung für die Fußballengesundheit beim Mastgeflügel. In: Zeyner A. (ed.). Conference Proceedings 12. Tagung Schweine- und Gefluegelernaehrung Halle;Wittenberg. (2013). p.108-20.

Knierim, U., Andersson, R., Keppler, C., Petermann, S., Rauch, E., Spindler, B. and Zapf, R. (2016): Tierschutzindikatoren: Leitfaden für die Praxis - Geflügel. Kuratorium für Technik und Bauwesen in der Landwirtschaft (KTBL). Darmstadt, Germany.

Köhler, W., Schachtel, G. and Voleske, P. (1995): Biostatistik: Einführung in die Biometrie für Biologen und Agrarwissenschaftler. 2. ed. Berlin: Springer.

Krautwald-Junghanns, M. E., Ellerich, R., Mitterer-Istyagin, H., Ludewig, M., Fehlhaber, K., Schuster, E. et al. (2011): Examinations on the prevalence of footpad lesions and breast skin lesions in British United Turkeys Big 6 fattening turkeys in Germany. Part I: Prevalence of footpad lesions. Poultry Sci. 90:555-560. doi: 10.3382/ps.2010-01046.

Lund, V. P., Nielsen, L. R., Oliveira, A.R.S. and Christensen, J. P. (2017): Evaluation of the Danish footpad lesion surveillance in conventional and organic broilers: Misclassification of scoring. Poultry Sci. 96:2018-2028. doi: 10.3382/ps/pex024.

Martland, M. F. (1984): Wet litter as a cause of plantar pododermatitis, leading to foot ulceration and lameness in fattening turkeys. Avian Pathol. 13:241-252. doi: $10.1080 / 03079458408418528$.

Martland, M.F. (1985): Ulcerative dermatitis in broiler chickens: The effects of wet litter. Avian Pathol. 14:353-364. doi: 10.1080/03079458508436237.

Martrenchar, A., Boilletot, E., Huonnic, D. and Pol, F. (2002): Risk factors for footpad dermatitis in chicken and turkey broilers in France. Prev Vet Med. 52:213-226. doi: 10.1016/S0167-5877(01)00259-8.

Mayne, R. K., Hocking, P. M. and Else, R. W. (2006): Foot pad dermatitis develops at an early age in commercial turkeys. Brit. Poultry Sci. 47:36-42. doi: $10.1080 / 00071660500475392$.

Mayne, R. K., Else, R. W. and Hocking, P. M. (2007): High litter moisture alone is sufficient to cause footpad dermatitis in growing turkeys. Brit. Poultry Sci. 48:538545. doi: 10.1080/00071660701573045.

Michel, V., Prampart, E., Mirabito, L., Allain, V., Arnould, C., Huonnic, D. et al. (2012): Histologically-validated footpad dermatitis scoring system for use in chicken processing plants. Brit. Poultry Sci. 53:275-281. doi: 10.1080/00071668.2012.695336

Petermann, S., Moors, E., Baumgarte, J. and Sürie, C. (2017): Tierschutzplan

Niedersachsen-Arbeitsergebnisse Nutzgeflügel. Berl Munch Tierarztl

Wochenschr.130:185-196. doi: 10.2376/0005-9366-16053.

Platt, S. (2004): Die reticulate scales an den Fußballen schwerer Mastputen und deren Beeinflussung durch unterschiedliche Biotindosierungen unter Feldbedingungen. [dissertation]. [Berlin (GE)]: Free University of Berlin.

Rudolf, M. (2008): Einfluss von Besatzdichte und Einstreumaterial auf die Pododermatitis bei Mastputen. [dissertation]. [Berlin (GE)]: Free University of Berlin. 
Spindler, B. (2007): Pathologisch-anatomische und histologische Untersuchungen an Gelenken und Fußballen bei Puten der Linie B.U.T. Big 6 bei der Haltung mit und ohne Außenklimabereich. [dissertation]. [Hanover (GE)]: University of Veterinary Medicine Hanover.

TierSchG (2017): "Tierschutzgesetz in der Fassung der Bekanntmachung vom 18. Mai 2006 (BGBl. I S. 1206, 1313), das zuletzt durch Artikel 141 des Gesetzes vom 29. März 2017 (BGBl. I S. 626) geändert worden ist".

TierSchNutztV (2016): "Tierschutz-Nutztierhaltungsverordnung in der Fassung der Bekanntmachung vom 22. August 2006 (BGBl. I S. 2043), die durch Artikel 3 Absatz 2 des Gesetzes vom 30. Juni 2017 (BGBl. I S. 2147) geändert worden ist".

Toppel, K. and Andersson, R. (2016): Tierschutzindikatoren und Gesundheitskontrollprogramm in der Mastputenhaltung. In: H. Louton (ed.). IGNInternational Society of Livestock Husbandry- Nutztierhaltung im Fokus Tierschutzindikatoren am Schlachthof. Muenchen.34-37.

Toppel, K., Kaufmann, F., Schön, H., Gauly, M. and Andersson, R. (2017): Development of mortality and foot pad health in turkey flocks and its implication for welfare assessment. Berl. Munch. Tierarztl. Wochenschr. 130:258-265. doi: 10.2376/0005-9366-16044.

Van Harn, J. and De Jong, I.C. (2017): Validation of Meyn Footpad Inspection System. Wageningen Livestock Research, Wageningen.

VDP (2013): Bundeseinheitliche Eckwerte für eine freiwillige Vereinbarung zur Haltung von Mastputen. Bundeseinheitliche Eckwerte, 01.10.2013.

Westermaier, C. (2015): Vergleichende Untersuchungen zur Tiergesundheit von konventionell gehaltenen Ross 308 und Cobb Sasso Masthühnern mit einem neuen Aufzuchtkonzept im Rahmen der konzeptionellen Ausarbeitung von Richtlinien für eine tiergerechtere Masthühnerhaltung. [dissertation]. [Munich (GE)]: LudwigMaximillian-University Munich.

Wilcox, C.S., Patterson, J. and Cheng, H.W. (2009): Use of thermography to screen for subclinical bumblefoot in poultry. Poultry Sci. 88:1176-1180. doi: $10.3382 /$ ps.2008-00446.

Wu, K. and Hocking, P. M. (2011): Turkeys are equally susceptible to foot pad dermatitis from 1 to 10 weeks of age and foot pad scores were minimized when litter moisture was less than $30 \%$. Poultry Sci. 90:1170-1178. doi: 10.3382/ps.2010-01202

Youssef, I.M.I., Beineke, A., Rohn, K. and Kamphues, J. (2011): Effects of Litter Quality (Moisture, Ammonia, Uric Acid) on Development and Severity of Foot Pad Dermatitis in Growing Turkeys. Avian Dis. 55:51-58. doi: 10.1637/9495-081010Reg.1. 
Effect of pH-lowering Litter Amendment on Animal-based welfare Indicators and Litter Quality in a European commercial Broiler Husbandry

\section{Chapter 5}

\section{Effect of pH-lowering Litter Amendment on Animal-based} welfare Indicators and Litter Quality in a European commercial Broiler Husbandry

Poultry Science Journal

$$
0 \text { (2018):1-9 }
$$

DOI: org/10.3382/ps/pey489 
Effect of pH-lowering Litter Amendment on Animal-based welfare Indicators and Litter Quality in a European commercial Broiler Husbandry

Effect of pH-lowering Litter Amendment on Animal-based welfare Indicators and Litter Quality in a European commercial Broiler Husbandry

K. Toppel ${ }^{1}$, F. Kaufmann ${ }^{1}$, H. Schoen ${ }^{1}$, M. Gauly ${ }^{2}$, R. Andersson ${ }^{1}$

${ }^{1}$ Faculty of Agriculture, University of Applied Sciences Osnabrueck, Germany

${ }^{2}$ Faculty of Science and Technology, Free University Bozen-Bolzano, Italy

Section: Management and Production

Key words: foot pad dermatitis, litter treatment, broiler, welfare, litter $\mathrm{pH}$ 
Effect of pH-lowering Litter Amendment on Animal-based welfare Indicators and Litter Quality in a European commercial Broiler Husbandry

\section{Abstract}

Several studies have shown that litter moisture is a major reason for foot pad lesions (FPD) and promotes microbial growth of nitrifying bacteria. The aim of the current study was to determine the possible effects of a sodium bisulfate-complex (SBS) as a litter additive on FPD, hock burn (HB) and litter parameters. Two application rates of SBS were examined in two experiments on a commercial farm. Two groups of about 30,000 broiler chicks each were introduced on spelt granulate spread at $700 \mathrm{~g} / \mathrm{m}^{2}$ and kept for 36 days. In the first experiment (TRT1), $250 \mathrm{~g} / \mathrm{m}^{2} \mathrm{SBS}$ was spread on top of litter 20 hours before chick placement; in the second experiment (TRT2), SBS was reduced to $150 \mathrm{~g} / \mathrm{m}^{2}$. Each experiment consisted of one treatment group (SBS) and a control group without treatment $(\mathrm{CON})$. Both experiments were repeated once. Litter parameters ( $\mathrm{pH}$, percentage of dry matter), foot pad and hock condition and body weight of randomly sampled birds $(n=60$ per group) were recorded weekly. Mortality rate was higher in SBS groups compared to CON groups (TRT1 2.79 vs. CON 2.03\%, TRT2 2.88 vs. CON 2.27\%). SBS had no effect on body weight averaged over the whole production period $(\mathrm{p}>0.05)$. The incidence of FPD was significantly reduced in both groups treated with SBS compared to CON $(p<0.05)$, with group TRT1 showing the best results. Incidence of HB was not affected by SBS ( $>00.05)$ but by dry matter content $(\mathrm{p}<0.05)$. At the beginning, SBS reduced litter $\mathrm{pH}$ to 1.7 and $2.0 \mathrm{in}$ TRT1 and TRT2 respectively, compared to 6.5 and 6.7 in CON. Litter $\mathrm{pH}$ in TRT groups increased over time and approached $\mathrm{pH}$ of control groups by day 15 . Results of the current study indicate that SBS treatment may be beneficial regarding foot pad health in broilers. However, further studies are needed to investigate alternative SBS application rates, dispersal intervals and to verify the results, especially regarding mortality rates and interaction between $\mathrm{pH}$, litter moisture and climate conditions.

Introduction

Associated with an intensified discussion about health and welfare in broiler husbandry, animal-based welfare assessment is increasing. To evaluate husbandry conditions, several animal-based indicators need to be monitored and evaluated on farms and in slaughterhouses (EFSA 2012, TierSchG 2017). According to the German Animal Protection Act, every stockman or owner of stock is obliged to assess animal- 
Effect of pH-lowering Litter Amendment on Animal-based welfare Indicators and Litter Quality in a European commercial Broiler Husbandry

based indicators (TierSchG 2017). In broilers and turkeys, foot pad and hock health were shown to be important indicators as they are directly correlated to husbandry conditions and on-farm management (Allain et al. 2009, De Jong et al. 2014). Thus, on-farm assessment of foot pads and hocks enables the stockman to identify and counteract adverse husbandry conditions at a very early stage (Bergmann et al. 2013). However, appropriate and effective measures have still not been suitably established and integrated within flock management and thus must be further improved (Allain et al. 2009, Welfare Quality 2009, Shepherd and Fairchild 2010, EFSA 2012). Of central importance in flock management, is the condition and quality of the litter, since it affects the health of foot pads (Mayne 2005, Shepherd and Fairchild 2010, Abd ElWahab et al. 2011, Taira et al. 2014) and hocks (Haslam et al. 2007) and the climatic conditions (corrosive gas) in the shed (Elliot and Collins 1982, Miles et al. 2011a). Therefore, several studies have been performed in order to evaluate the effects of different bedding materials on broiler performance and conditional changes of the bedding during production (Grimes et al. 2006, Berk 2007, Xu et al. 2015) as well as different litter treatments and additives to enhance and maintain litter quality. The litter treatments investigated were calcium oxide (Ruiz et al. 2008), acidified clay, aluminum sulfate and sodium bisulfate (McWard and Taylor 2000). One method of improving litter and air quality is to reduce litter $\mathrm{pH}$. This practice is widespread and well-established in the US broiler industry (Jones-Hamilton 2017). The utilized products (e.g. Poultry Litter Treatment ${ }^{\circledR}$; PLT) mainly consist of sodium bisulfate (SBS) (Tasistro et al. 2007, Jones-Hamilton 2017). In contrast to the European Union, most of the chicks in the US are placed on re-used litter (Nagaraj et al. 2007, Wheeler at el. 2008, Bolan et al. 2010). US poultry housing systems are often without concrete flooring and litter is used for up to two years or even longer without being replaced, however the top portion may be changed before introducing day-old chicks (Rhodes et al. 2011). The recommended application rates of PLT range between $370-490 \mathrm{~g} / \mathrm{m}^{2}$ for litter material newer than 1 year and between $490-730 \mathrm{~g} / \mathrm{m}^{2}$ for litter material older than one year, whereby no further treatment such as tilling is recommended (JonesHamilton, 2017). Several studies investigated the effect of SBS and the lowered $\mathrm{pH}-$ value in poultry litter on foot pad health (McWard and Taylor 2000, Nagaraj et al. 2007), hock health and ammonia content (Terzich et al. 1998b, Tasistro et al. 2007). 
Effect of pH-lowering Litter Amendment on Animal-based welfare Indicators and Litter Quality in a European commercial Broiler Husbandry

The studies differed regarding application rates of SBS between $220 \mathrm{~g} / \mathrm{m}^{2}$ (Nagaraj et al. 2007), $244 \mathrm{~g} / \mathrm{m}^{2}$ (Pope and Cherry 2000, Blake and Hess 2001, Tasistro et al. 2007, Johnson and Murphy 2008, Wheeler et al. 2008, Li et al. 2013), 440 g/ m² (Nagaraj et al. 2007) and $582 \mathrm{~g} / \mathrm{m}^{2}$ (McWard and Taylor 2000) and between spreading SBS on top of re-used litter (Moore et al. 1996, McWard and Taylor 2000, Li et al. 2013) or on top of new litter material (Tasistro et al. 2007). In contrast to the husbandry conditions in the US, a cleaning and disinfection procedure must be performed in Germany before housing day-old chicks for a new production cycle (TierSchNutztV, 2017). The bedding material needs to be new, dry and clean and has to cover the concrete floor. Furthermore, litter material needs to be friable in order to address and promote characteristic behavior such as scratching, foraging and dust bathing (TierSchNutztV 2017, Welfare Quality 2009; Dunlop and Stuetz 2016). Those litter conditions are completely different to re-used litter material as described above. The prevalence and severity of foot pad dermatitis (FPD) is mostly influenced by the moisture content of the feces-litter material (Abd-El Wahab et al. 2011). However, water activity should also be taken into account (Dunlop et al., 2016). Another factor that influences the occurrence of FPD is the presence of skin irritating substances such as ammonia and uric acid (Youssef et al., 2011). $\mathrm{NH}_{3}$ content in turn depends on the $\mathrm{pH}$ and dry matter content (DM) of the litter material (Pope and Cherry, 2000; Dawkins et al. 2004, Miles et al. 2011, Xu et al. 2015, Bergmann et al. 2016). The level of $\mathrm{NH}_{3}$ volatilization also differs within a shed as litter moisture varies between different functional areas within the shed (Tasistro et al. 2004b, Tasistro et al. 2007).

Currently, the use of sodium bisulfate as a litter treatment in animal husbandry systems is not explicitly permitted in the European Union. However, sodium bisulfate is a legal food additive (EU 231/2012) and furthermore a feed additive (EU 2015/1414) for pets and other animals not destined for consumption (EU 2012, EU 2015). According to the European Food Safety Authority, a dosage of $4000 \mathrm{mg} / \mathrm{kg}$ complete feed is stated as safe for fattening chicken (EFSA 2014). The objective of the current study was to assess the effects of SBS supplementation to broiler litter on bird health, welfare and performance as well as the environmental conditions in the shed. 
Effect of pH-lowering Litter Amendment on Animal-based welfare Indicators and Litter Quality in a European commercial Broiler Husbandry

\section{Materials and Methods}

\section{$\underline{\text { Experimental design }}$}

The study was conducted on a commercial broiler farm in North-West Germany (October 2016 - March 2017). The farm consisted of two broiler grow-out houses which were used for two trials. As the maximum stocking density was restricted to 39 $\mathrm{kg} / \mathrm{m}^{2}$ (TierSchNutztV, 2017), each house provided space for 30,000 birds $\left(1,600 \mathrm{~m}^{2}\right)$. For the first trial, one house housed the control group whereas the litter in the second house was supplemented with a sodium bisulfate-complex (SBS) and thus, the treatment group. For the second trial, the setting remained the same whereby the level of supplemented SBS in the treatment group differed from trial one. Both trials were repeated once. Besides the differences regarding litter, both grow-out houses were identical concerning technical equipment (e.g. amount and type of feeders and drinkers, ventilation system) and applied management, yet the sheds for the control and treatment group alternated in each trial and repetition.

\section{$\underline{\text { Animals and Management }}$}

A total of 240,000 Ross 308, day-old chicks (Aviagen Group, Huntsville, USA) were used in this study. For each group and cycle within the trial, 30,000 day-old chicks obtained from the same parent stock were housed simultaneously and then raised for 36 days until slaughter. A commercial diet and water were provided ad libitum. The energy levels of the diets were between 12.6 MJ/kg ME (1st week of development) and 13.2 MJ/kg ME (5th week of development), the protein levels ranged between $22.0 \%$ and $19.5 \%$ CP until slaughter. All other management aspects were in accordance with the national requirements for broiler husbandry (TierSchNutztV, 2017).

\section{$\underline{\text { Litter and Litter Treatment }}$}

A mixture of spelt pellets and spelt granulate (30:70) was used as bedding material in all groups. The bedding material was dispersed once before housing the birds, whereby $700 \mathrm{~g}$ bedding material per $\mathrm{m}^{2}$ was dispersed using a spreader. The bedding material of the treatment groups was supplemented with a $250 \mathrm{~g}$ and $150 \mathrm{~g}$ sodium bisulfate- 
Effect of pH-lowering Litter Amendment on Animal-based welfare Indicators and Litter Quality in a European commercial Broiler Husbandry

complex (GRILLO-ACT, Grillo-Werke AG, Duisburg, Germany) per $\mathrm{m}^{2}$ in trial one (treatment 1: TRT1; SBS250) and trial two (treatment 2: TRT2; SBS150), respectively. The SBS-complex was manually dispersed on top of the bedding material using a lawn seed spreader. Supplementation occurred 24 hours before housing the chicks.

\section{$\underline{\text { Data collection }}$}

The mortality rate (\%) was continuously monitored on a daily basis by the flock manager. From the first day of life until slaughtering, the foot pads of 60 randomly selected birds per group were assessed at seven-day intervals. Samples of the birds were collected from different areas within a shed. Additionally, foot pads from 90 birds per group were scored in the slaughterhouse post mortem (p.m.). Both feet of an individual were given scores, the worse foot pad and the highest score between the two hock/feet of an individual was taken for analysis. The plantar area of both foot pads of individual birds was graded according to the five-point scale from Welfare Quality® (2009). The score ranges from 0 (no external signs of FPD, swelling or necrosis) to 4 (visible epithelial lesions, massive hyperkeratosis and necrotic areas covering more than half of the plantar area). The depth of a lesion was not recorded. Hock burn lesions (Score 0 - no lesions to Score 4 - severe lesions, in accordance with Welfare Quality ${ }^{\circledR}$ (2009)) and weight development (FlexScale electronic scale with a precision of $+/-1$ g; Big Dutchman, Vechta, Germany) were recorded for the same sampled birds.

\section{$\underline{\text { Litter samples }}$}

Litter samples were collected at seven-day intervals from the day of housing until slaughter. Samples were taken from three different areas within each broiler house: around water lines (DL), around feeder lines (FL) and around the free area (FA) (modified from Tasistro et al., 2004b). Within the area 'water lines' and 'feeder lines', 20 subsamples were combined and defined as one sample representing each area. For the 'free area' 12 subsamples were taken and combined accordingly. Litter samples were taken from the full depth of the litter with a standardized punch. The determination of litter $\mathrm{pH}$ was performed using duplicate suspensions of $5.0 \mathrm{~g}$ of poultry litter. $140.0 \mathrm{~g}$ deionized water was added to the respective sample and the $\mathrm{pH}$ was measured by Microprocessor pH 320 with a SenTix electrode (WTW Weilheim, 
Effect of pH-lowering Litter Amendment on Animal-based welfare Indicators and Litter Quality in a European commercial Broiler Husbandry

Germany) calibrated using a buffer for $\mathrm{pH} 4.00,7.00$ and 9.21. Dry matter content of the litter was determined three times according to weight loss after drying the pooled litter samples in a forced-draft oven for $24 \mathrm{~h}$ at $105^{\circ} \mathrm{C}$ (Darr method, DIN 52183). The triple determination of ammonium was done by water vapor distillation and titration, using a semiautomatic distillation device (Vapodest 20s, Gerhard Comp., Koenigswinter, Germany). $\mathrm{NH}_{3}$ was released by $\mathrm{MgO}$ and calcinated by water vapor in boric acid. Titration with a $\mathrm{HCl}$ solution $(\mathrm{c}=0.1 \mathrm{~mol} / \mathrm{l})$ was applied in order to determine $\mathrm{NH}_{3}$ and finally $\mathrm{NH}_{4}-\mathrm{N}$ was calculated according to VDLUFA (2014) as follows: $\mathrm{N}$ in litter sample $(\%)=(\mathrm{HCl}(\mathrm{ml}) * 1.40067 * 100) /$ sample weight $(\mathrm{mg})$

\section{$\underline{\text { Statistical analysis }}$}

Mortality was analyzed descriptively. Results of live weight were logarithmized over the whole period to obtain variance homogeneity. Data were tested with variance analysis (SPSS Vs.26) to calculate differences between groups within treatments by time point and over the whole production period on significance level with $\alpha=0.05$. Further differences related to live weight were calculated based on the following model: $y i, j, k=\mu+$ time + group + barn + group $*$ barn + group*time + barn*time + eijk, with time (day of life; 8, 15, 22, 29), group (SBS250, SBS150, SBS0(=CON)) and barn (1, 2).

The results of the foot pad and hock burn grading at different time points were presented as frequency distribution (percentage per category). Differences were tested with Mann-Whitney U-test $(\alpha=0.05)$. Stepwise forward multiple regression analysis (SPSS Vs.26) was used to analyze the effect of different litter variables on foot pad and hock rating at farm level. The following regression model was constructed:

$y 1,2=\beta 0+\beta 1 * x 1+\beta 2 * x 2+\beta 3 * x 3+\beta 4 * x 4+\beta 5 * x 5$

$\mathrm{y} 1=\mathrm{FPD}, \mathrm{y} 2=\mathrm{HB}$ with depended variables: $\mathrm{x} 1$ = time (day of life; 8, 15, 22, 29, 36), $\mathrm{x} 2=\mathrm{pH}$ (mean across all 3 sample categories Drinker Line (DL), Feeder Line (FL), Free Area (FA)), x3 = DM (mean across all 3 sample categories DL, FL, FA), x4 = NH4-N (mean across all three sample categories DL, FL, FA), x5 = group (SBS250, SBS150, SBS0). 
Effect of pH-lowering Litter Amendment on Animal-based welfare Indicators and Litter Quality in a European commercial Broiler Husbandry

To calculate the effects on ammonium, an analysis of variance was calculated with the effects time (day of life; 1, 8, 15, 22, 29, 36), group (SBS250, SBS150, SBS0), area (DL, FL, FA) and cycle (cycle 1+2 (=TRT1) and 3+4 (=TRT2)). Cycles 1-2 and 3-4 were analyzed separately because of different treatments. The following model was constructed:

yijk $=$

$\mu+$ cycle+group + area+time + cycle* ${ }^{*}$ group + area*time+group*time+group*area+eijk.

Results

Growth rate and mortality

Results of live bird weight showed differences during the production period in TRT1 and TRT2 (Table 13). No statistical differences between groups within TRT1 and TRT2 were calculated over the period from the 1 st to 29 th day (TRT1 $\mathrm{p}=0.687$, TRT2 $\mathrm{p}=0.890$ ). Mortality rates showed an approximate $0.5 \%$ higher cumulative seven-day rate in all SBS groups, leading to a higher overall mortality rate in SBS groups compared to control groups (Table 13).

Table 13: Broiler performance of SBS flocks and control flocks in treatment 1 (TRT1) and 2 (TRT2) at different times (d) (weight: $n=60$ birds/date and each group; 2 replications per group)

\begin{tabular}{lccccc|cc} 
Treatment & \multicolumn{5}{c|}{ Weight, g (Mean/SD) } & \multicolumn{2}{c}{ Mortality, \% } \\
& $\mathrm{d} 0$ & $\mathrm{~d} 8$ & $\mathrm{~d} \mathrm{22}$ & $\mathrm{d} 29$ & $\mathrm{P}^{\dagger}$ & $\mathrm{d} 1$ to 7 & d 1 to 36 \\
\hline TRT1-SBS $_{250}$ & $46.3 \pm 3.9$ & $206.4 \pm 21.5$ & $1077.7 \pm 106.8^{\mathrm{b}}$ & $1647.6 \pm 215.5$ & \multirow{2}{*}{0.687} & 1.07 & 2.79 \\
TRT1-CON $_{250}$ & $47.1 \pm 4.3$ & $206.3 \pm 22.2$ & $1047.5 \pm 110.7^{\mathrm{a}}$ & $1616.0 \pm 179.7$ & & 0.66 & 2.03 \\
\hline TRT2-SBS $_{150}$ & $42.0 \pm 2.8^{\mathrm{a}}$ & $188.9 \pm 27.0$ & $972.2 \pm 119.7^{\mathrm{a}}$ & $1551.9 \pm 187.5$ & \multirow{2}{*}{0.890} & 1.40 & 2.88 \\
TRT2-CON $_{150}$ & $43.8 \pm 2.8^{\mathrm{b}}$ & $183.1 \pm 25.1$ & $1004.1 \pm 107.5^{\mathrm{b}}$ & $1532.8 \pm 169.2$ & & 0.89 & 2.27
\end{tabular}

Live weight: ${ }^{a, b}$ column means followed by different superscript letters are significantly different within a TRT $(\alpha=0.05)$;

$\dagger$ row means from d 0 to d 29 significantly different within a TRT $\mathrm{p}<0.05$.

Foot pad and hock health

The results of the foot pad and hock grading from day 8 to 22 and p.m. are presented in Table 14. Foot pad health was positively influenced by both SBS treatments. The higher dosage of SBS resulted in the best foot pad health. At the end of fattening, the percentage of foot pads without lesions was 18.8 percentage points higher in SBS250 
Effect of pH-lowering Litter Amendment on Animal-based welfare Indicators and Litter Quality in a European commercial Broiler Husbandry

compared to CON250 ( $\mathrm{p}=0.011)$. With lower SBS treatment (TRT 2), the difference was about 8 percentage points in favor of SBS150 flocks compared to CON150 (p = 0.000). The severity of FPD was relatively low in all groups as only a few birds were rated category 3 or 4 . The prevalence of hock burn was not influenced by SBS application, no differences between groups were measured $(\mathrm{p}>0.05$; Table 14). Hock burns were graded after the first week in all groups and hock health decreased to about $67 \%$ of birds having HB in TRT $1,72 \%$ (SBS150) and to $79 \%$ (CON150) HB in TRT2 in both groups p.m.

Different predictors with a possible impact on foot pad and hock health were calculated with stepwise multiple regression analysis. From all predictors which were tested at significance level of $p<0.05$, 'Group' $(p=0.046)$ influenced foot pad health with $\mathrm{R}^{2}$ $=0.379(\mathrm{SE}=0.149)$. The less SBS applied the higher the foot pad lesions were scored (=worst score number).

The significant impact of predictors 'time' $(p=0.000)$ and 'DM content' $(p=0.037)$ were pointed out regarding hock burn. With an increased age and decreased DM content skin irritation and dermatitis on hocks were increasing.

Table 14: Occurrence of foot pad lesions (\%) and hock burn (\%) in treatment 1 (TRT1) and 2 (TRT2) depending on bird's age (score 1/2 and 3/4 were pooled for paper presentation)

\begin{tabular}{|c|c|c|c|c|c|c|c|c|c|c|c|c|c|c|c|}
\hline \multirow[b]{3}{*}{$\begin{array}{c}\text { Bird } \\
\text { age (d) }\end{array}$} & \multirow[b]{3}{*}{$\begin{array}{c}\mathrm{n} / \\
\text { group* }\end{array}$} & \multicolumn{10}{|c|}{ Foot pad lesion (\%) } & \multirow{2}{*}{\multicolumn{3}{|c|}{ TRT2-CON 150}} & \multirow[b]{3}{*}{$\mathrm{P}^{\dagger}$} \\
\hline & & \multicolumn{3}{|c|}{ TRT1-SBS 250} & \multicolumn{3}{|c|}{ TRT1-CON 250} & \multirow[b]{2}{*}{$\mathrm{P}^{\dagger}$} & \multicolumn{3}{|c|}{ TRT2-SBS 150} & & & & \\
\hline & & $\begin{array}{c}\text { Score } \\
0\end{array}$ & $1 / 2$ & $3 / 4$ & 0 & $1 / 2$ & $3 / 4$ & & 0 & $1 / 2$ & $3 / 4$ & 0 & $1 / 2$ & $3 / 4$ & \\
\hline 8 & 120 & 85.0 & 15.0 & 0.0 & 78.3 & 21.7 & 0.0 & 0.122 & 82.5 & 17.5 & 0.0 & 85.0 & 15.0 & 0.0 & 0.122 \\
\hline 22 & 120 & 89.2 & 10.0 & 0.8 & 83.3 & 16.7 & 0.0 & 0.055 & 80.8 & 17.5 & 1.7 & 78.4 & 20.8 & 0.8 & 0.132 \\
\hline p.m. & 180 & 79.4 & 20.0 & 0.6 & 60.6 & 37.8 & 1.6 & 0.011 & 68.3 & 30.6 & 1.1 & 58.9 & 39.4 & 1.7 & 0.000 \\
\hline \multicolumn{16}{|c|}{ Hock burn (\%) } \\
\hline 8 & 120 & 99.2 & 0.8 & 0.0 & 94.2 & 5.8 & 0.0 & 0.034 & 96.7 & 3.3 & 0.0 & 98.3 & 1.7 & 0.0 & 0.664 \\
\hline 22 & 120 & 49.2 & 50.8 & 0.0 & 45.0 & 53.3 & 1.7 & 0.221 & 74.2 & 25.8 & 0.0 & 73.3 & 26.7 & 0.0 & 0.484 \\
\hline p.m. & 180 & 32.8 & 66.7 & 0.5 & 30.6 & 68.9 & 0.5 & 0.200 & 28.3 & 71.7 & 0.0 & 22.2 & 77.2 & 0.6 & 0.115 \\
\hline
\end{tabular}

*60 (on-farm) or 90 (post mortem; 36 days) pairs of foot pads and hocks were scored per group and repetition, both feet and hocks were evaluated, presented data is based on the worse foot or hock

$\dagger$ significance level $\alpha=0.05$; Mann-Whitney U-Test 
Effect of pH-lowering Litter Amendment on Animal-based welfare Indicators and Litter Quality in a European commercial Broiler Husbandry

Litter parameters $\mathrm{pH}$-value and dry matter

Both SBS application rates reduced litter $\mathrm{pH}$ from 6.47 and 6.71 in control groups to 1.67 and 1.96 in TRT1 and TRT2 respectively, at first sampling date. Litter pH was below 4 in both groups treated with SBS until day 8 and under 6 until the 15th day in the SBS group TRT1. However, the change in litter $\mathrm{pH}$ depended on the sampling areas (Table 15). Data regarding (DM) showed less DM content at the first sampling date in both SBS treatment groups. Especially in the area around the drinker lines, DM content decreased to $59.9 \%$ at day 15 in TRT1 and to $57.95 \%$ in TRT2, about 4 to 5 points lower compared to the control groups (Table 15). Values below $65 \%$ DM were measured from day 15 to day 36 in SBS group TRT1 and TRT2 around drinker lines, with the exception of day 29 in TRT2 $(\mathrm{DM}=66.40 \%)$. 
Effect of pH-lowering Litter Amendment on Animal-based welfare Indicators and Litter Quality in a European commercial Broiler Husbandry

Table 15: Litter parameter $\mathrm{pH}$ and dry matter content (\%) depending on sampling date and sampling area; 'Drinker Line' (DL), 'Feeder Line' (FL) and 'Free Area' (FA) (SBS=Sodium bisulfate; $C O N=$ control group)

Parameter Area Group

Day of life

\begin{tabular}{|c|c|c|c|c|c|c|c|c|}
\hline Treatmer & & & 1 & 8 & 15 & 22 & 29 & 36 \\
\hline \multirow{6}{*}{$\mathrm{pH}$} & \multirow[t]{2}{*}{ DL } & $\mathrm{SBS}_{250}$ & $1.67 \pm 0.12$ & $3.03 \pm 0.21$ & $5.78 \pm 0.04$ & $6.27 \pm 0.12$ & $6.63 \pm 0.27$ & $6.77 \pm 0.61$ \\
\hline & & $\mathrm{CON}$ & $6.47 \pm 0.09$ & $6.10 \pm 0.06$ & $6.09 \pm 0.28$ & $6.47 \pm 0.02$ & $6.83 \pm 0.60$ & $8.36 \pm 0.07$ \\
\hline & \multirow[t]{2}{*}{$\mathrm{FL}$} & $\mathrm{SBS}_{250}$ & $1.67 \pm 0.12$ & $2.35 \pm 0.12$ & $4.86 \pm 0.05$ & $5.98 \pm 0.10$ & $6.76 \pm 0.06$ & $7.47 \pm 0.09$ \\
\hline & & $\mathrm{CON}$ & $6.47 \pm 0.09$ & $6.13 \pm 0.10$ & $5.87 \pm 0.02$ & $6.16 \pm 0.02$ & $6.79 \pm 0.16$ & $6.43 \pm 0.34$ \\
\hline & \multirow[t]{2}{*}{ FA } & $\mathrm{SBS}_{250}$ & $1.67 \pm 0.12$ & $2.58 \pm 0.10$ & $4.93 \pm 0.42$ & $6.54 \pm 0.16$ & $7.76 \pm 0.52$ & $8.41 \pm 0.28$ \\
\hline & & $\mathrm{CON}$ & $6.47 \pm 0.09$ & $6.10 \pm 0.00$ & $6.08 \pm 0.26$ & $6.87 \pm 0.17$ & $8.35 \pm 0.30$ & $8.65 \pm 0.02$ \\
\hline
\end{tabular}

$\begin{array}{llllllll}\mathrm{DL} & \mathrm{SBS}_{250} & 90.75 \pm 0.05 & 72.75 \pm 3.95 & 59.90 \pm 0.40 & 61.85 \pm 1.15 & 63.15 \pm 0.15 & 58.95 \pm 1.85\end{array}$

$\begin{array}{lllllll}\text { CON } & 91.55 \pm 0.25 & 76.55 \pm 0.85 & 64.05 \pm 2.45 & 61.10 \pm 1.70 & 61.35 \pm 0.35 & 62.30 \pm 0.30\end{array}$

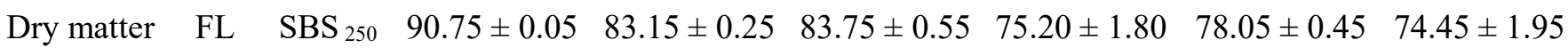

$(\%)$

\begin{tabular}{|c|c|c|c|c|c|c|c|}
\hline & $\mathrm{CON}$ & $91.55 \pm 0.25$ & $85.80 \pm 0.20$ & $80.10 \pm 2.60$ & $75.40 \pm 0.50$ & $73.70 \pm 0.20$ & $67.15 \pm 0.25$ \\
\hline FA & $\mathrm{SBS}_{250}$ & $90.75 \pm 0.05$ & $77.65 \pm 3.15$ & $77.05 \pm 0.95$ & $72.85 \pm 0.55$ & $70.25 \pm 1.35$ & $60.55 \pm 2.55$ \\
\hline & $\mathrm{CON}$ & $91.55 \pm 0.25$ & $80.15 \pm 2.55$ & $76.85 \pm 3.85$ & $74.30 \pm 0.20$ & $65.65 \pm 0.75$ & $65.50 \pm 1.40$ \\
\hline
\end{tabular}

Treatment 2

$\mathrm{pH}$

\begin{tabular}{cccccccc}
$\mathrm{DL}$ & $\mathrm{SBS}_{150}$ & $1.96 \pm 0.05$ & $4.26 \pm 0.20$ & $6.18 \pm 0.13$ & $7.42 \pm 1.01$ & $7.79 \pm 0.86$ & $6.42 \pm 1.34$ \\
& $\mathrm{CON}$ & $6.71 \pm 0.36$ & $6.07 \pm 0.04$ & $6.74 \pm 0.36$ & $8.23 \pm 0.36$ & $6.22 \pm 0.73$ & $5.93 \pm 0.91$ \\
\hline
\end{tabular}

$\begin{array}{llllllllll}\mathrm{pH} & \mathrm{FL} & \text { SBS }_{150} & 1.96 \pm 0.05 & 4.58 \pm 0.85 & 6.03 \pm 0.25 & 6.24 \pm 0.33 & 6.80 \pm 0.03 & 6.76 \pm 0.38\end{array}$

\begin{tabular}{cccccccc} 
& CON & $6.71 \pm 0.36$ & $6.12 \pm 0.08$ & $6.10 \pm 0.09$ & $6.87 \pm 0.13$ & $6.72 \pm 0.14$ & $6.83 \pm 0.80$ \\
\hline \multirow{2}{*}{ FA } & SBS $_{150}$ & $1.96 \pm 0.05$ & $3.37 \pm 0.95$ & $6.15 \pm 0.27$ & $8.24 \pm 0.47$ & $8.57 \pm 0.27$ & $8.92 \pm 0.03$ \\
& CON & $6.71 \pm 0.36$ & $6.13 \pm 0.04$ & $6.22 \pm 0.02$ & $7.92 \pm 0.29$ & $8.85 \pm 0.04$ & $8.71 \pm 0.24$ \\
\hline
\end{tabular}

$\begin{array}{llllllll}\mathrm{DL} & \mathrm{SBS}_{150} & 90.70 \pm 0.20 & 67.45 \pm 0.35 & 57.95 \pm 1.95 & 63.25 \pm 0.35 & 66.40 \pm 3.20 & 58.75 \pm 6.55\end{array}$ $\begin{array}{lllllll}\text { CON } & 91.95 \pm 0,05 & 73.65 \pm 6.95 & 60.55 \pm 2.15 & 62.30 \pm 3.20 & 56.25 \pm 4.05 & 56.60 \pm 5.30\end{array}$

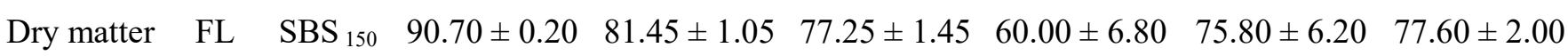
$(\%)$ \begin{tabular}{lllllll} 
CON & $91.95 \pm 0.05$ & $85.50 \pm 0.40$ & $80.10 \pm 0.60$ & $68.45 \pm 5.15$ & $78.15 \pm 0.75$ & $78.35 \pm 0.25$ \\
\hline
\end{tabular}

$\begin{array}{llllllll}\text { FA } & \text { SBS }_{150} & 90.70 \pm 0.20 & 75.80 \pm 7.30 & 71.35 \pm 5.15 & 67.80 \pm 0.70 & 70.80 \pm 0.90 & 67.65 \pm 0.15\end{array}$ $\begin{array}{lllllll}\mathrm{CON} & 91.95 \pm 0.05 & 83.25 \pm 1.65 & 77.45 \pm 1.05 & 73.15 \pm 2.95 & 67.40 \pm 0.70 & 62.70 \pm 2.30\end{array}$ 
Effect of pH-lowering Litter Amendment on Animal-based welfare Indicators and Litter Quality in a European commercial Broiler Husbandry

\section{$\underline{\text { Litter parameter ammonium }}$}

$\mathrm{NH}_{4}-\mathrm{N}$ concentration at the start of production was lower in Trial 1 than in trial 2 (Figure 6 and Figure 7). Within the trials, the $\mathrm{NH}_{4}-\mathrm{N}$ content in fresh mass at day 1 of production was between 0.003 (SBS250) and $0.005 \%(\mathrm{CON})$ in Trial 1 and 0.017 (SBS150) and $0.022 \%(\mathrm{CON})$ in Trial 2, respectively. At day 15 of production, $\mathrm{NH}_{4}-$ $\mathrm{N}$ content differed between the sampling areas in all groups, whereby the lowest concentration was measured around the feeder lines (FL). The maximum values of $\mathrm{NH}_{4}-\mathrm{N}$ in fresh mass were measured on day 36. Litter samples from TRT1 at the end of fattening resulted in $0.501 \% \mathrm{NH}_{4}-\mathrm{N}$ (DL), $0.448 \% \mathrm{NH}_{4}-\mathrm{N}$ (FL) and $0.541 \% \mathrm{NH} 4-$ $\mathrm{N}$ (FA) in the SBS250 group and $0.549 \%$ (DL), $0.365 \%(\mathrm{FL})$ and $0.500 \%$ (FA) in the CON group (Figure 6). Compared to that, the level of $\mathrm{NH}_{4}-\mathrm{N}$ in TRT2 was lower at day 36 with $\mathrm{NH}_{4}-\mathrm{N}$ in the litter at $0.391 \%$ (DL), $0.339 \%$ (FL) and $0.440 \%$ (FA) within SBS150 and $0.365 \%$ (DL), $0.325 \%$ (FL) and $0.505 \%$ (FA) within the CON group (Figure 7). Focusing on the amount around water lines (DL), the calculated mean within SBS150 was highest at day $29\left(0.451 \% \mathrm{NH}_{4}-\mathrm{N}\right)$.

The $\mathrm{NH}_{4}-\mathrm{N}$ values increased significantly over time $(\mathrm{p}=0.000)$. The results of these analyses showed no significant mean effect of the treatment (TRT1 $p=0.443$ and TRT2 $p=0.602$ ). There were significant differences between the means of the sampled areas (TRT1 $\mathrm{p}=0.009$, TRT2 $\mathrm{p}=0.049)$. 
Effect of pH-lowering Litter Amendment on Animal-based welfare Indicators and Litter Quality in a European commercial Broiler Husbandry

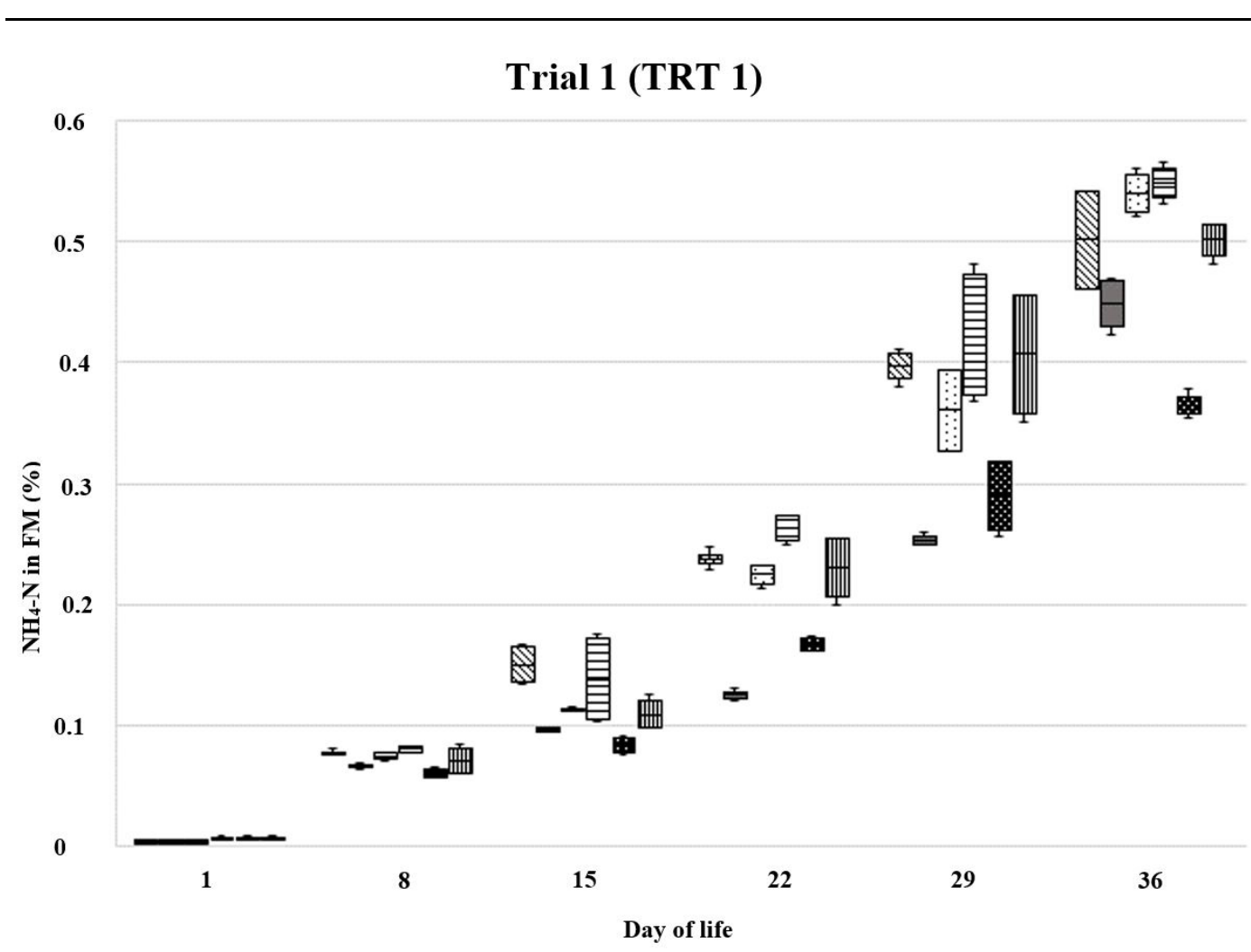

$\mathbb{Q}$ SBS_DL $\square$ SBS_FL $⿴$ SBS_FA $\boxminus$ Con_DL Con_FL 四Con_FA

Figure 6: Ammonium-N (\%) in fresh mass (FM) within TRT1 (SBS=SBS250) at different areas $(D L=$ Drinker Line, $F L=$ Feeder Line, $F A=$ Free Area) 
Effect of pH-lowering Litter Amendment on Animal-based welfare Indicators and Litter Quality in a European commercial Broiler Husbandry

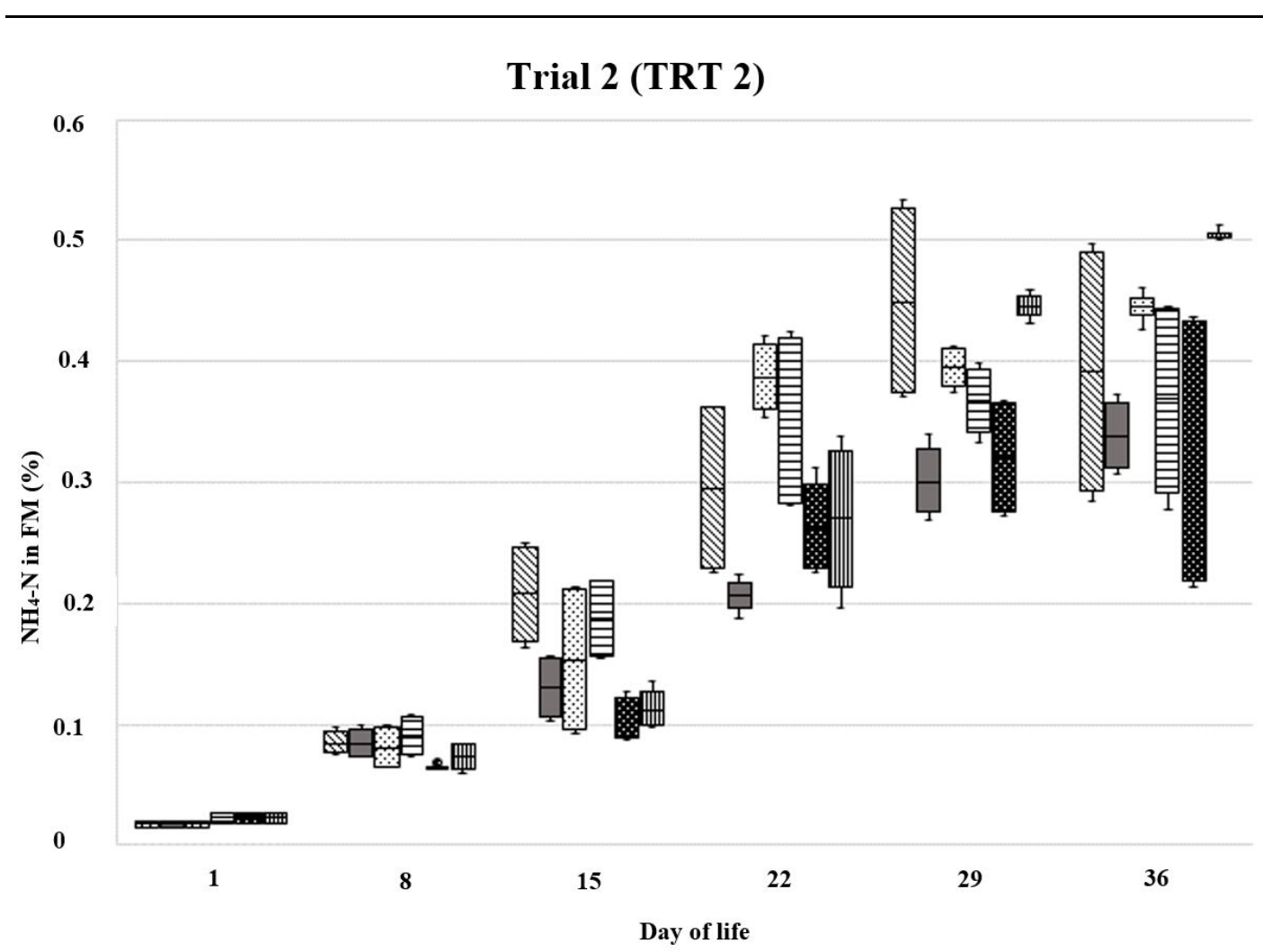

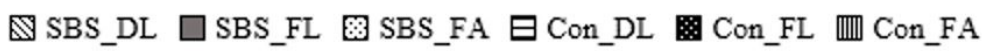

Figure 7: Ammonium-N (\%) in fresh mass within TRT2 (SBS150) at different floor points $(D L=$ Drinker Line, $F L=$ Feeder Line, $F A=$ Free Area)

\section{Discussion}

Growth rate and mortality

The performance traits of the broilers in all groups are comparable with commercial production figures (Damme, 2017) indicating that the broiler houses were well operated and that the underlying conditions of the study represent practical conditions. Nevertheless, the sample size of 60 birds and 60 feet (resp. 180 feet p.m.) per time point and group needs to be considered when interpreting the data. The mortality rate was below the national average of $3.54 \%$ (Damme, 2017) in all groups. However, when focusing on first-week mortality, the mortality rate in the SBS groups was higher compared to the control groups. Other studies with SBS application found no difference between groups (McWard and Taylor, 2000; Nagaraj et al., 2007; Tasistro et al., 2007), but those studies were conducted under well-defined and experimental husbandry conditions, or significantly lower mortality rates in treated groups (Li et al., 
Effect of pH-lowering Litter Amendment on Animal-based welfare Indicators and Litter Quality in a European commercial Broiler Husbandry

2013). Terzich et al. (1998a) also described a positive effect of SBS on mortality rates as less birds suffered from ascites following SBS treatment. Furthermore, Terzich et al. (1998a) postulates that those observations may be consequent to the reduced NH3 levels in the SBS groups. In the present study, birds were placed on fresh and dry bedding material so $\mathrm{NH}_{3}$ emission rates were initially not an issue (Tasistro et al., 2007). Another indicator, which has to be addressed when evaluating SBS application regarding health and safety, is the performance of the birds reflected by their live weight. With focus on the overall production period the current experiment showed no significant difference on body weight within treatments, which is in accordance with other studies (Nagaraj et al., 2007; Tasistro et al., 2007; Li et al., 2013). Contrarily, some authors observed increased body weights in SBS treated groups compared to control groups (McWard and Taylor, 2000; Terzich et al., 1998b).

\section{Foot pad and hock health}

Foot pad health was better within the SBS treated groups at all samplings. However, very few feet were assessed to score 3 and 4, indicating severe lesions, which may reflect the good management at farm-level, especially in winter when FPD prevalence is expected to be higher than in the summer season (Haslam et al., 2007). Deficient ventilation and an increase of condensation water lead to a higher litter moisture which has proven to be the main factor influencing foot pad health as chicken feet are in permanent contact with litter material during the course of a fattening period (Mayne et al., 2007; Abd El-Wahab et al., 2011). A positive effect of straw granulate compared to chopped straw and wood shaving on foot pad health was investigated by Berk (2007) and could be a reason for less than two percent of scored feet classified as severe lesions in both groups of both trials. Youssef et al. (2010) described that the physical form of litter material, e.g. sharp edges, may promote the occurrence of skin irritations. That could explain the record of first alterations like rhagades or redness in all groups after the first week. At the same time litter moisture increased, especially around waterers, up to 15 to $20 \%$. Litter moisture increased over time and foot pad health became worse in all groups and Mayne et al. (2007) and Youssef et al. (2011) assume that water softens and opens the collagen matrix of metatarsal pads' skin. That would trigger the immune system and also bacteria proliferation would be stimulated (Eichner et al., 2007) and thus promote dermatitis. However, from the first day after 
Effect of pH-lowering Litter Amendment on Animal-based welfare Indicators and Litter Quality in a European commercial Broiler Husbandry

applying SBS the DM content in the litter was even below the DM content in the CON groups. That may be explained by the hygroscopic characteristic of SBS (Nagaraj et al., 2007; Li et al., 2013) but would also indicate an effect of a low pH-value by SBS application on FPD. In the present study the factor 'Group' influenced foot pad health $(p=0.046)$ and the less SBS was applied the higher the foot pad lesions were scored (= worst score number). The low initial $\mathrm{pH}$-value of less than $\mathrm{pH} 2$ compared to $\mathrm{pH} 6$ in CON groups might have reduced microbial activity and Tasistro et al., (2007) suspected a lasting acidifying effect even though $\mathrm{pH}$ increased above $\mathrm{pH} 6$ after day 15 (TRT1) or day 8 (TRT2) in the present study. Furthermore, the low pH-value caused by SBS reduces water activity $\left(a_{w}\right)$ in litter and consequently reduces the amount of water the birds' feet get in contact with (Dunlop et al., 2016). The positive effect from SBS supports the results from the experimental study of Li et al. (2013) who even reapplicated $183 \mathrm{~g} / \mathrm{m}^{2}$ SBS during the husbandry period. When litter was treated twice with $220 \mathrm{~g} / \mathrm{m}^{2}$ SBS, Nagaraj et al. (2007) evaluated a trend of improved foot pad health but litter moisture was below $20 \%$ during production period.

Within the current experiment litter moisture and time (= age) in combination increased HB prevalence significantly, which supports results from Hepworth et al. (2010). The results in Table 14 show no difference in HB between the SBS and CON groups. Considering the data of DM in litter the increase of litter moisture is similar between groups with ongoing production period. The early occurrence of hock lesions confirms investigations from Bergmann at al. (2016) who monitored hock lesions on Ross broilers in a field trial after five days post hatch. Feed composition is described as an impact factor regarding litter quality and thus, as a cause for foot pad lesions and hock dermatitis in consequence of polyuria due to high protein levels and electrolytes like sodium and potassium, for example (Shepherd and Fairchild, 2010; Haslam et al., 2007). This might have had an effect on those animal-based indicators in this research but feeding rations were identical in both groups.

\section{Litter parameters $\mathrm{pH}$-value and dry matter}

DM content decreased with continuous moisture input from excreta, drinker lines and condensation water (Table 15). The differences between several areas in the shed were greater than the differences of DM content between groups. Also Dunlop et al. (2016) 
Effect of pH-lowering Litter Amendment on Animal-based welfare Indicators and Litter Quality in a European commercial Broiler Husbandry

observed caked litter underneath waterlines and mostly dry litter in free areas, which clarifies the differences of the litter quality between areas in the shed. The critical DM content of $65 \%$ and less, proven by Abd-El Wahab et al. (2011) as a reason and intensifier for FPD, was measured around DL as late as day 15 in both trials and groups. Based on the higher moisture level in litter of SBS groups from the beginning of the production period the hygroscopic characteristic of SBS may become evident. As soon as water is absorbed into SBS the chemical compound dissolves into $\mathrm{Na}+, \mathrm{H}+$ and $\mathrm{SO}_{4-}$ (Johnson and Murphy 2008). The released $\mathrm{H}+$ reduce litter $\mathrm{pH}$ and react with $\mathrm{NH}_{3}$ to form the irreversible component $\mathrm{NH}_{4}+$, which wouldn't release nitrogen $(\mathrm{N})$ when litter pH increases again (Johnson and Murphy, 2008).

\section{$\underline{\text { Litter parameter ammonium }}$}

Based on recorded $\mathrm{NH}_{4}-\mathrm{N}$, no evidence for lowering $\mathrm{NH}_{3}$ volatilization was discovered. $\mathrm{NH}_{4}-\mathrm{N}$ is significantly influenced by time, as the $\mathrm{NH}_{4}-\mathrm{N}$ content in the litter increased over the course of a fattening period. Tasistro et al. (2004b) described the lowest decomposition rate around FL with a $17 \%$ water content in the litter, followed by FA with a $30 \%$ water content and DL with a $55 \%$ water content in the litter, which is supported by the present data in Figure 6 and Figure 7 and may explain differences between sample points. However, SBS application did not increase $\mathrm{NH}_{4}-$ $\mathrm{N}$ in the litter as recorded by Tasistro et al. (2007) and derived from Tasistro et al. (2004b) who found a strong positive correlation $(\mathrm{r}=0.81)$ between $\mathrm{pH}$ and $\mathrm{NH}_{3}-\mathrm{N}$. Decomposition by bacteria may be higher and increases $\mathrm{NH}_{3}$ volatilization (Tasistro et al. 2004b). As a consequence of low $\mathrm{pH}$ in the litter, and depending on the litter water content (Miles et al. 2011b), volatilization of $\mathrm{NH}_{3}$ should be suppressed as shown by Tasistro et al. (2007). In the same study, the pH value was lower around feeders and in free areas compared to the area around water lines, which is contrary to the current findings. Possibly, sample collection and differences in litter material as well as the amount of material influenced the results, as they spread a $5 \mathrm{~cm}$-deep layer of litter material compared to only $700 \mathrm{~g} / \mathrm{m}^{2}$, which were dispersed before chick placement in this study. Moore et al. (1996) could not prove an effect of $\mathrm{NaHSO}_{4}$ on $\mathrm{NH}_{4}$ in litter after 42 days under experimental conditions (CON $3.27 \mathrm{~g}$ vs. SBS $3.91 \mathrm{~g}$ $\mathrm{NH}_{4} / \mathrm{kg}$ litter). Although they top-dressed SBS on re-used litter, the amount of $20 \mathrm{~g}$ SBS $/ \mathrm{kg}$ litter might have been too low to initiate a change. Blake and Hess (2001) 
Effect of pH-lowering Litter Amendment on Animal-based welfare Indicators and Litter Quality in a European commercial Broiler Husbandry

published that bacterial decomposition of uric acid increases above litter $\mathrm{pH}$ of 7 and uricase activity is highest at $\mathrm{pH}$ of 9 . Compared to the results in the present study litter pH was below 7 until 22nd day in TRT1 and day 15 in TRT2 in both groups and did not reach pH 9 within both treatments. That could explain similar results of NH4-N between groups at least until the latter time points. Moreover, McWard and Taylor (2000) assumed that litter $\mathrm{pH}$ does not directly correspond with measured $\mathrm{NH}_{3}$, because the sulfate load from SBS would interfere with the metabolic process of the bacteria in litter and hence reduce the ability to transform $\mathrm{NH}_{3}$ (McWard and Taylor, 2000). The authors showed that the effect of reducing litter $\mathrm{pH}$ below $\mathrm{pH} 7$ by SBS lasted about five to seven days after SBS application, compared to the $\mathrm{NH}_{3}$ reduction beneath 20ppm until 30 days after SBS application. Finally, a direct measurement is recommended to prove a relationship between litter quality and $\mathrm{NH}_{3}$ (Tasistro et al., 2007; Li et al., 2013).

Overall, SBS application to litter did not affect animal health and welfare detrimentally. 7-day mortality was about $0.5 \%$ higher compared to control groups. The reasons are unclear and need to be examined in further studies. Due to the reduction of microbial activity in consequence of a lower $\mathrm{pH}$-value and finally a lower $a_{w}$-value, investigations into free water content and water activity $\left(a_{w}\right)$ could be useful to describe the relationship between SBS application and foot pad health (Dunlop et al., 2016). Due to less effects on bird's welfare from the lower SBS application rate the economic aspect was neglected and requires consideration in further studies. As foot pad health was better in SBS groups, the results of the study may indicate that the use of SBS as a litter additive is beneficial to birds' health and welfare. Therefore, SBS application may be a useful measure in stock management to prevent or at least reduce FPD, especially severe lesions, and help to increase health and welfare in chicken stock.

\section{Conflict of interest}

All authors declare that there are no conflicts of interests. 
Effect of pH-lowering Litter Amendment on Animal-based welfare Indicators and

Litter Quality in a European commercial Broiler Husbandry

Ethics Statement

The study was carried out in accordance with the German legislations, the German 'Animal Protection Act' (TierSchG, 2017) and the 'Statutory order for housing and environmental conditions of farm animals' (TierSchNutztV, 2017) as well as the 'Guide for the Care and Use of Agricultural Animals in research and Teaching' (Ag Guide 2010).

\section{References}

Abd El-Wahab, A., Beineke, A. Beyerbach, M., Visscher C.F. and Kamphues, J. (2011): Effects of floor heating and litter quality on the development and severity of foot pad dermatitis in young turkeys. Avian Dis. 55:429-434.

Ag Guide (2010): Guide for the Care and Use of Agricultural Animals in Research and Teaching. 3rd edition. Federation of Animal Science Societies. Chapter 9:

Poultry. 103-128. Available online http://www.poultryscience.org/docs/agguide/AG_Guide_3rdEd.pdf.

Allain, V., Mirabito, L., Arnould, C., Colas, M., Le Bouquin, S., Lupo, C. and V. Michel (2009): Skin lesions in broiler chickens measured at the slaughterhouse: relationships between lesions and between their prevalence and rearing factors. Br. Poultry Sci. 50:407-417.

Bergmann, S., Louton, H., Westermaier, C., Wilutzky, K., Bender, A., Bachmeier, J., Erhard M.H. and Rauch, E. (2016): Field trial on animal-based measures for animal welfare in slow growing broilers reared under an alternative concept suitable for the German market. Berl. Munch. Tierarztl. Wochenschr. DOI 10.2376/0005-936616035.

Berk, J. (2007): Foot pad dermatitis in male broilers depending on different kinds of litter. Fußballendermatitis bei männlichen Broilern in Abhängigkeit von unterschiedlichen Einstreuarten. Landbauforschung Voelkenrode. 2:171-178.

Blake, J.P. and Hess, J.B. (2001): Sodium Bisulfate (PLT) as a Litter Treatment. Alabama Cooperative Extension System, ANR-1208, Alabama A\&M and Auburn Universities.

Bolan, N.S., Szogi, A.A., Chuasavathi, T., Seshadri, B. Rothrock, M.J. and Panneerselvam, P. (2010): Uses and management of poultry litter. Worlds Poultry Sci. J. 66:673-698.

Damme, K. (2017): Poultry Business studies. Faustzahlen der Landwirtschaft. In: Gefluegeljahrbuch 2018. Eugen Ulmer Verlag. Stuttgart. Germany. 84.

Dawkins, M.S., Donnelly, C.A. and Jones, T.A. (2004): Chicken welfare is influenced more by housing conditions than by stocking density. Nature. 427:342-344.

De Jong, I.C., Hindle, V.A., Butterworth, A., Engel, B., Ferrari, P., Gunnink, H., Perez Moya, T., Tuyttens, F.A.M. and van Reenen, C.G. (2016): Simplifying the Welfare Quality ${ }^{\circledR}$ assessment protocol for broiler chicken welfare. Animal. 10:117-127. 
Effect of pH-lowering Litter Amendment on Animal-based welfare Indicators and

Litter Quality in a European commercial Broiler Husbandry

Dunlop, M.W. and Stuetz, R.M. (2016): Wet Litter - Factors associated with the shed micro-environment and litter properties. Proc. of $27^{\text {th }}$ Annual Australian Poultry Science Symposium. 21-28. Available online:

https://sydney.edu.au/vetscience/apss/documents/2016/APSS\%202016\%20Proceedin gs\%20Final.pdf

Dunlop. M.W., Moss, A.F., Groves, P.J., Wilkinson, S.J., Stuetz, R.M. and Selle, P.H. (2016): The multidimensional causal factors of 'wet litter' in chicken-meat production. Sci. of the total Environm. 562:766-776.

Eichner, G., S.L. Vieira, C.A. Torres, J.L.B. Coneglian, D.M. Freitas, and Oyarzabal, O.A. (2007): Litter moisture and footpad dermatitis as affected by diets formulated on all-vegetable basis or having the inclusion of poultry by-product. J. Appl. Poultry Res. 16:344-350.

EFSA (2014): EFSA Panel on Additives and Products or Substances used in Animal Feed (FEEDAP). Scientific Opinion on the safety and efficacy of sodium bisulphate (SBS) for all species as preservative and silage additive. EFSA Journal. 12:3731. doi:10.2903/j.efsa.2014.3731

EFSA (2012): EFSA Panel on Animal Health and Welfare (AHAW) Scientific Opinion on the use of animal-based measures to assess welfare of broilers. EFSA Journal. 10:2774. doi:10.2903/j.efsa.2012.2774.

Elliott, H.A. and Collins, N. E. (1982): Factors affecting ammonia release in broilers houses. ASEA Publ. 25:413-424.

EU. 2015. Commission Implementing Regulation (EU) 2015/1414 of 20 August 2015 amending Implementing Regulation (EU) No 136/2012 concerning the authorization of sodium bisulphate as feed additive for pets and for non-food producing animals. Available online https://eur-lex.europa.eu/legalcontent/EN/TXT/PDF/?uri=CELEX:32015R1414\&from=DE

EU. 2012. Commission Regulation (EU) No 231/2012 of 9 March 2012 amending Annex III to Regulation (EC) No 1333/2008 of the European Parliament and of the Council on food additives by establishing a Union list of food additives. ABI. No L 83. Available online https://eurlex.europa.eu/LexUriServ/LexUriServ.do?uri=OJ:L:2012:083:0001:0295:DE:PDF

Grimes, J.L., T.A. Carter, and Godwin, J.L. (2006): Use of a Litter Material Made From Cotton Waste, Gypsum, and Old Newsprint for Rearing Broiler Chickens. Poultry Sci. 85:563-568.

Haslam, S.M., Knowles, T.G., Brown, S.N., Wilkins, L.J., Kestin, S.C., Warriss, P.D. and Nicol, C.J. (2007): Factors affecting the prevalence of foot pad dermatitis, hock burn and breast burn in broiler chicken. Br. Poultry Sci. 48:264-275.

Hepworth, P.J., Nefedoc, A.V., Muchnik, I.B. and Morgan, K.L. (2010): Early warning indicators for hock burn in broiler flocks. Avian Pathol. 39:405-409.

Johnson, T.M. and Murphy, B. (2008): Use of Sodium Bisulfate to Reduce Ammonia Emissions from Poultry and Livestock Housing. In: Muhlbauer, E., Moody, L., Burns, R. (Ed.) "Mitigating Air Emissions from Animal Feeding Operations Conference Proceedings", 74-78, Armes: Iowa State University. 
Effect of pH-lowering Litter Amendment on Animal-based welfare Indicators and

Litter Quality in a European commercial Broiler Husbandry

Jones Hamilton (2017): Walbridge, OH, USA. http://joneshamiltonag.com/

Li, H., Lin, C., Collier, S., Brown, W. and White-Hansen, S. (2013): Assessment of frequent litter amendment application on ammonia emission from broilers operations. J. Air Waste Ma. 63:442-452.

Mayne, R.K. (2005): A review of the aetiology and possible causative factors of foot pad dermatitis in growing turkeys and broilers. Worlds Poultry Sci. J. 61:256-267.

Mayne, R.K., Else, R.W. and Hocking, P.M. (2007): High litter moisture alone is sufficient to cause footpad dermatitis in growing turkeys. Br. Poultry Sci. 48:538-545.

McWard, G.W. and Taylor, D.R. (2000): Acidified Clay litter Amendment. J. Appl. Poultry Res. 9:518-529.

Miles, D.M., Rowe, D.E. and Catcart, T.C. (2011a): High litter moisture content suppresses litter ammonia volatilization. Poultry Sci. 90:1397-1405.

Miles, D.M., Rowe, D.E. and Catcart, T.C. (2011b): Litter ammonia generation: moisture content and organic versus inorganic bedding materials. Poultry Sci. 90:1162-1169.

Moore, P.A., Daniel, T.C., Edwards, D.R. and Miller, D.M. (1996): Evaluation of Chemical Amendments to Reduce Ammonia Volatilization from Poultry Litter. Poultry Sci. 75:315-320.

Nagaraj, M., Wilson, C.A.P., Saenmahayak, B., Hess, J.B. and Bilgili, S.F. (2007): Efficacy of a Litter Amendment to Reduce Pododermatitis in Broiler Chickens. J. Appl. Poultry Res. 16:255-261.

Pope, M.J. and Cherry, T.E. (2000): An Evaluation of the Presence of Pathogens on Broilers raised on Poultry Litter Treatment ${ }^{\circledR}-$ Treated Litter. Poultry Sci. 79:13511355.

Rhodes, J.L., Timmons, J., Nottingham, J.R. and Musser, W. (2011): Broiler Production Management for Potential and Existing Growers. University of Maryland. https://extension.umd.edu//sites/extension.umd.edu/files/_docs/POULTRY_BroilerPr oductionManagement_final1.pdf

Ruiz, V., Ruiz, D., Gernat, A.G., Grimes, J.L., Murillo, J.G., Wineland, M.J., Anderson, K.E. and Maguire, R.O. (2008): The effect of quicklime (CaO) on litter condition and broiler performance. Poultry Sci. 87:823-827.

Shepherd, E.M. and Fairchild, B.D. (2010): Foot pad dermatitis in poultry. Poultry Sci. 89:2043-2051.

Taira, K., Nagai, T., Obi, T. and Takase, K. (2014): Effect of Litter Moisture on Development of Footpad Dermatitis in Broiler Chickens. J. Vet. Med. Sci. 76: 583586.

Tasistro, A.S., Ritz, C.W. and Kissel, D.E. (2007): Ammonia emissions from broiler litter: response to bedding materials and acidifiers. Br. Poultry Sci. 48:399-405.

Tasistro, A.S., Kissel, D.E. and Bush, P.B. (2004a): Sampling broiler litter: How many samples are needed? J. Appl. Poultry Res. 13:163-170. 
Effect of pH-lowering Litter Amendment on Animal-based welfare Indicators and

Litter Quality in a European commercial Broiler Husbandry

Tasistro, A.S., Kissel, D.E. and Bush, P.B. (2004b): Spatial variability of Broiler litter composition in a chicken house. J. Appl. Poultry Res. 13:29-43.

Terzich, M., Quarles, C., Goodwin, M.A. and Brown, J. (1998a): Effect of Poultry Litter Treatment ${ }^{\mathbb{B}}\left(\right.$ PLT $\left.^{\mathbb{R}}\right)$ on Death Due to Ascites in Broilers. Avian Dis. 42:385-387.

Terzich, M., Quarles, C., Goodwin, M.A and Brown, J. (1998b): Effect of Poultry Litter Treatment ${ }^{\circledR}\left(\right.$ PLT $\left.^{\circledR}\right)$ on the development of respiratory tract lesions in broilers. Avian Pathol. 27:566-569.

TSchG. 2017. German Animal Welfare Act. Tierschutzgesetz in der Fassung der Bekanntmachung vom 18. Mai 2006 (BGBl. I S. 1206, 1313), das zuletzt durch Artikel 141 des Gesetzes vom 29. März 2017 (BGBl. I S. 626) geändert worden ist. Available online: http://www.gesetze-im-internet.de/tierschg/TierSchG.pdf.

TierSchNutztV. 2017. German Legal Standard on the Protection of Animals and Animal husbandry conditions. Tierschutz-Nutztierhaltungsverordnung in der Fassung der Bekanntmachung vom 22. August 2006 (BGBl. I S. 2043), die durch Artikel 3 Absatz 2 des Gesetzes vom 30. Juni 2017 (BGB1. I S. 2147) geändert worden ist.

VDLUFA (2014): Determination of $\mathrm{NH}_{4}-\mathrm{N}$ - Distillation with MgO. In: VDLUFA (ed.) „Methodenbuch II.2 Die Untersuchung von Sekundärrohstoffdüngern, Kultursubstraten und Bodenhilfsstoffen“, 1. Aufl. mit 2. Erg., Darmstadt: VDLUFAVerlag. Germany.

Welfare Quality (2009): Welfare Quality assessment protocol for poultry (broiler, laying hens). Welfare Quality consortium. Lelystad, Netherlands.

Wheeler, E., Casey, K., Gates, R., Xin, H., Liang, Y. and Topper, P. (2008): Litter Management Strategies in Relation to Ammonia Emissions from Floor-Raised Birds. In: Muhlbauer, E., L. Moody and Burns, R. (ed.) Mitigating Air Emissions from Animal Feeding Operations Conference Proceedings. Iowa State University. 99-103.

Youssef, I.M.I., Beineke, A., Rohn, K. and Kamphues, J. (2010): Experimental study on effects of litter material and its quality on foot pad dermatitis in growing turkeys. Int. J. Poultry Sci. 9:1125-1135.

Youssef, I.M.I., Beineke, A., Rohn, K. and Kamphues, J. (2011): Effects of Litter Quality (Moisture, Ammonia, Uric Acid) on Development and Severity of Foot Pad Dermatitis in Growing Turkeys. Avian Dis. 55:51-58.

Xu, Y., Stark, C.R., Ferket, P.R., Williams, C.M., Auttawong, S. and Brake, J. (2015): Effects of dietary coarsely ground corn and litter type on broiler live performance, litter characteristics, gastrointestinal tract development, apparent ileal digestibility of energy and nitrogen, and intestinal morphology. Poultry Sci. 94:353-361. 


\section{Chapter 6 - General Discussion}

The overall objective of this thesis was to investigate the parameters foot pad health and mortality regarding their suitability as animal related indicators in broiler and turkey flocks. In this chapter, the limitations of the study and the main results will be discussed in a first step, recommendations for an indicator-based flock management will be presented and discussed in a second step. The studies and trials for this thesis were conducted facing the dilemma of performing research in field studies with their respective advantages (e.g. sample size) and disadvantages (e.g. repeatability regarding housing conditions and validity of on-farm documentation) (Dawkins 2012).

The main part of the first study (Chapter 3) was to monitor and evaluate the parameters 'mortality' and 'foot pad health' in a field study regarding their suitability and usability as welfare-related indicators in turkey flocks. All farms which participated in this study, were located in north-west Germany. Those farms were considered to be representative for commercial turkey production in Germany as half of the turkeys (5.3 M birds) which are kept in Germany are located in that area, precisely in Lower Saxony (ML Niedersachsen 2016).

Comparable on-farm husbandry conditions were ensured by fulfilling the standards of the national frameworks (VDP 2013) and the National Turkey Health Program (VDP 2013) and the federal legal requirements (Nds. MBI 2014). Opposing to the large number of male turkeys per cycle (85,000 toms) only 18,500 hens contributed to the data collection and assessment per production cycle which has to be taken into account when interpreting the data of hens. To consider seasonal effects on each farm one summer and one winter cycle were monitored and evaluated.

The same source of data was used for calculations for the second study (Chapter 4) in which the prevalence of foot pad alterations during rearing and the applied scoring scheme were assessed. Here again, data of female birds were less than data from male flocks but still provided an adequate calculation base. A comparison between macroscopic and histological assessment of foot pads was conducted in order to evaluate the validity of the macroscopic procedure to detect painful alterations. Out of 30 macroscopically assessed feet, 10 feet with different scores were undertaken a further histopathological examination to verify the macroscopic results and to 
investigate the depth of a lesion which influences animal welfare. For histological examination under a light microscope the feet were stained using haematoxylin and eosin which is a common and well described procedure (Mayne et al. 2007).

Finally, twenty randomly selected pictures from turkey foot pads and digits were analyzed with an image processing program (ImageJ) to evaluate a camera-based foot pad assessment system. The program Image J is established as a laboratory tool and is used, inter alia, to analyze, measure and picture biological surfaces (Abramoff et al. 2004, Collins 2018, Doube et al. 2010). Results of the two assessment methods were categorized based on the scheme of Hocking et al. (2008) as this scheme is not only established as an european standard system to evaluate foot pad dermatitis on-farm but also provides the basis for post mortem assessment of foot pads at German slaughterhouses (VDP 2013).

In order to provide potential solutions to improve foot pad health on farm level, one certain management measure was evaluated regarding its potential to influence foot pad health (Chapter 5). Although this study was conducted in broilers, the results are still transferable to turkey production as the pathogenesis of foot pad dermatitis is comparable between the two species and production systems (Martland 1985, Martrenchar et al. 2002, Mayne et al. 2007, Youssef 2011).

A farm which runs three commercial broiler barns, thereof two barns, which were involved in the study, were identical in construction. Each house provided space for about 30,000 Ross 308 birds, which meets a standard broiler operation in Germany (Damme 2018). Litter material such as straw pellets, which were used in the trial, are a common material in German broiler production (Berk 2017). Due to several positive effects like water binding and releasing capacity and hygienic advantages straw pellets are expected to be used widespread in future as well. To reduce external influences both houses were changed between cycles and control and treatment group.

\section{Use of the indicator 'mortality' as part of on-farm-monitoring in poultry flocks}

The German Animal Protection Act (§11,8 TierSchG 2017) obligates animal keepers to introduce and apply an on-farm-monitoring and controlling system in order to maintain and improve animal health and welfare, based on related indicators and prove 
fulfilling the $\S 2$ TierSchG (TierSchG 2017). In accordance to Lorz and Metzger (2019) §2 TierSchG obliges the poultry farmer to enable birds to express innate behavior. Husbandry conditions for activity, care, housing and feeding have to fulfill the needs of the birds, whereby poultry farming includes certain restrictions, and therefore, it enables not an optimal but appropriate feeding and housing (Lorz und Metzger 2019). Hence, as a welfare indicator mortality was suggested to be used as an early detector of those conditions (Andersson et al. 2015). Due to an indicator-based system implying a continuous target-performance comparison and the monitoring of threshold values, conspicuousness in the flock would be signalized too late by limit values of mortality. The approach of an on-farm controlling requires, besides information about influences on mortality, knowledge about certain frames of risk, threshold values as well as target values. Glatz and Rodda (2013) pointed out several potential risk factors that might contribute to mortality, like hatchery and husbandry conditions with little differences between sex. Compared to the results of the field study in Chapter 3, where no differences between male and female mortality rate were pointed out during rearing, turkey experts $(n=10)$ estimated higher mortality rates in male flocks (2.4\%) compared to female flocks (1.8\%) in a survey (Toppel et al. 2016). To indicate needs-based feeding and care by mortality rate there is actually no difference to be expected during the rearing period between sex, as turkey poults have similar immune status and depend on similar husbandry conditions like external heat and feed requirements for maintenance (Gauly 2016, Jeroch et al. 2019). This is sustained by the results of the seven-day mortality, which is about $1 \%$ for male and female birds (0,7-1,2 \%; Table 7). Results from Chapter 3 showed a positive correlation between 1 st-week mortality and cumulative 35-day mortality ( $\mathrm{r}=0.677$, $\mathrm{p}<0.01$ ). Therefore, the 7-day mortality rate could be used as part of the flock monitoring and basis for specific management decisions.

As opposed to overall mortality results, different risk factors for first week mortality divided by male and female turkey flocks were pointed out by Carver et al. (2002). Summarizing the results, the probability of risks from hatchery and transportation parameters differ between sex but overall-rearing mortality was not published in the study. For risk-oriented assessment, reasons for early mortality often derive from hatchery processing or transportation issues from the hatchery to the farm (Yassin et 
al. 2009). According to Quinton et al. (2011), the heritability of early survival is low in turkeys, however strain-specific influences on mortality, correlated to season, were identified by Carver et al. 2002. More detailed and shared information regarding strain and hatchery conditions would support the barn preparation for day-old chicks as well as transport conditions and age of the parent stock which largely influences the weight and vitality of the poults (Carver et al. 2002). The quantity and quality of the shared information via Hatchery and Farmer also influences early management strategies on the farm for example regarding barn temperature, frequency of feed application as well as flock inspection intervals and the prospective vaccination strategy. Those aspects were not investigated in the field study of Chapter 3 but the information sharing would complete an on-farm monitoring and controlling. To reduce early mortality is not only a financial appeal but it could increase on-farm welfare and reduce rearing mortality as frequent reasons for early mortality are "non-starters", umbilical and yolk sac infections, polyserositis, runts, colibaccilosis and crushing (Toppel et al. 2016). Under experimental conditions Roehrig and Torrey (2019) published a $4.1 \%$ ( $\mathrm{N}=960$ birds) 7-day mortality whereas most of the birds died due to yolk sac infection and starvation which is in accordance with Kulke et al. (2014) who pointed out navel and yolk sac infections as the main reasons for early mortality in an experimental study. Improvement of barn conditions at day of hatch and housing (temperature, feed and water availability) might help to improve poult livability (Bir et al. 2019, Carver et al. 2002) and would reduce overall rearing mortality rate.

The factors season and sex were identified in our study to be considered when evaluating mortality during grow-out period. Within a comparable study to investigate indicators in turkey flocks results for mortality rates were asked for based on a survey among commercial farms with 11 male flocks and 13 female flocks (KrautwaldJunghanns and Fehlhaber 2009). Derived from the questionnaire it is not clear whether the data about average mortality rates include the rearing and fattening period or cover the grow-out period. Krautwald-Junghanns and Fehlhaber (2009) expected a mean of $9 \%$ mortality in male flocks, which was approved by $n=5$ farms, while four farms mentioned more than $9 \%$ and two farms declared a mortality rate lower than $9 \%$ per cycle. Mortality in female flocks was considerably lower, as the average was targeted at $4 \%$ and results of the questionnaire were $n=10$ lower than $4 \%$, two farms estimated 
$4 \%$ and one farm resulted in more than $4 \%$ female mortality per cycle. KrautwaldJunghanns and Fehlhaber (2009) mentioned the easy monitoring of the parameter 'mortality' but an 'increased mortality' in terms of an indicator or a conspicuous flock was not precisely determinable in that study. It would underline the use of 'mortality' as a retrospective parameter but the difficulties to use it as part of a risk-oriented assessment of poultry flock health. Similar threshold values for mortality (cumulated) in female flocks were proposed to be $4 \%$ during rearing and fattening by Rautenschlein and Ryll (2014), which is in accordance with field data from SchmitzDumont and König (2014), indicating a mortality around 3.9\%. Also low precisely data for male flocks are similar between both authors as well, indicating a cumulative mortality about $10 \%$ (Rautenschlein and Ryll 2014) and 10.3\% (Schmitz-Dumont and König 2014), respectively. As a retrospective data it is comparable to the results of chapter 3 (Table 7). Another survey data was published from Toppel et al. (2016). In order to obtain data about the average mortality rate in German turkey husbandry, data from female and male flocks were collected surveying German turkey experts $(\mathrm{n}=10)$ who mentioned $1.8 \%$ cumulative mortality in female birds and $2.4 \%$ cumulative mortality in male birds over the rearing period (Toppel et al. 2016). For the grow-out period, $3.5 \%$ and $8.6 \%$ is stated as the cumulative mortality for female and male flocks, respectively. This data shows the necessity of the differentiation between sex and also the age-related periods rearing and fattening if the state of health of a farm flock should be assessed reliably as part of a benchmark system.

In terms of the detection of early deviations, evaluating the weekly mortality rate would support this approach. The presented field data in Chapter 3 showed a weekly mortality during the rearing and grow-out period. The average weekly mortality rate resulted in $0.16 \%$ (summer) to $0.19 \%$ (winter) for female and $0.43 \%$ (summer) to $0.38 \%$ (winter) for male birds, respectively. Summarizing the data, the cumulated fattening mortality rate in female flocks was between $1.8 \%$ and $2.1 \%$ from week 6 to week 17 and $6.9 \%$ and $6.1 \%$ for male flocks from 6th to 21 st week of age. Compared to the field study of Krautwald-Junghanns and Fehlhaber (2009), who supposed a mean of $9 \%$ male and $4 \%$ female mortality, the collected data in the present study are clearly lower. In the experimental study from Rudolf (2008) the author expected $7 \%$ and $10 \%$ mortality in female compared to male flocks while it is not clearly mentioned 
if this includes the period of rearing and fattening or just the grow-out period. In the study from Rudolf (2008) the effect of different stocking densities regarding health parameters were investigated and mortality rates were between $2.5 \%$ and $5.6 \%$ in female flocks ( $\mathrm{n}=$ about 8,000 birds) and between $4.9 \%$ and $14.6 \%$ in male flocks ( $\mathrm{n}=$ about 4,300 turkeys). Beside differences between sex, mortality rates were considerably different between summer and winter cycle (female flocks up to $3.5 \%$ during winter vs. max. $5.6 \%$ mortality during summer, male flocks max. $6.1 \%$ during winter vs. up to $14.6 \%$ mortality during summer respectively). The need for the difference of targeted values by sex and season became clear in that study.

Differences between methods of monitoring and evaluation could be reasons for deviations between study results, as it was decided in 2014, with the implementation of the Turkey health program, to standardize the rearing period from day 0 until 35 th day of life. Therefore, current results may only hardly be comparable with studies before defining the temporal extent of the rearing period. Furthermore, farmers would frequently exclude data from the first three days when calculating the mortality as they are referred to the hatchery and transport conditions rather than on the farm and its management itself.

The parameter weekly mortality supports an early detection of deviations from target values. As part of the on-farm monitoring weekly mortality would indirectly indicate e.g. need-based feeding additionally to feed consumption and average daily weight and thus fulfill demands for an on-farm monitoring ( $\$ 11,8$ TierSchG 2017). Above legal requirements Lorz and Metzger (2019) outlined the necessity for a functional circuit wide assessment which would include searching for feed as well (Lorz and Metzger 2019 (1 TierSchG §2, S.88)). The latter aspect is supported by a friable litter structure while clean and friable litter also enable a need-demand care for turkeys (VDP 2013). With reference to risk periods for mortality in broiler and turkey flocks, reducing heat stress and the risk to die by ensuring friable and fresh litter for the birds is a recommended preventive management measure (VDP 2013).

Besides being a key figure for the evaluation of assessing animal welfare and flock health, the mortality rate is also of crucial importance when evaluating economic aspects of the productions system (Ferrante et al. 2019). Even if late mortality is economically more important than early mortality (Wood 2009), at least at first sight, 
the positive correlation of 7-day mortality and overall rearing mortality underlines the importance of implementing early preventive management measures. A comprehensive documentation of mortality reasons could support the identification of risk-factors and help to reduce rearing and thus overall turkey mortality.

Growing turkeys are often kept separately from fattening farms. The clear different demands in management and husbandry conditions between turkey poults and fattening birds led to a widespread division between both production sites. The current 'Bundeseinheitliche Eckwerte für eine freiwillige Vereinbarung zur Haltung von Mastputen' include minimum recommendations for the rearing period like the number of drinkers per birds and the documentation of rearing mortality. The health program which is part of the voluntary recommendations requests just the documentation and evaluation of indicators from the fattening period to assess the flocks' health and welfare (VDP 2013) which is similar to the food supply chain (QS 2020). While the rearing period represents five weeks of birds' life and rate of losses indicate health conditions and give an expectation of the constitution of the flock, there is a lack of information about mortality rates towards the slaughtering company but also towards the fattening production site.

The collected data in Chapter 3 based on flocks which were owned and managed on the same farm from poult placement to slaughtering and flocks which were sold and moved to another flock manager after rearing. The number of flocks was too low to correlate the mortality rate between rearing and fattening for the different production types in the present study. In general, birds will be delivered between 28 and 35 days to the grow-out facility. The weight of birds is calculated by the mean of the flock, measured on the truck when the birds are loaded. To estimate the state of health and vitality of the new flock the farmer at the fattening unit needs to monitor and evaluate a number of animal welfare related indicators.

To implement prospective and precise management measures, time frames of risk for mortality needed to be identified. This risk frames were presented in our study whereas a high risk for mortality could be identified for weeks 14 and 15, independent from seasonal effects. Furthermore, mortality within weeks 12 to 13 and 'late mortality' harbors an increased risk and needs to be particularly addressed in flock management, especially during the summer months. In general, the course of mortality during 
summer and winter cycle clearly points out a profound difference between the 'better' (below 1st quartile up to the 2nd quartile = median) and the more 'problematic' flocks (above 3rd quartile). Despite the mortality and course of mortality being agedependent, the curve shapes of mortality are rather linear in the 1st and 2nd quartile but strongly fluctuating in the 3rd one. The curving of the mortality encourages the suggestion, that the flock management in general and deviation and variations in flock management in particular may directly influence mortality rates and thus, underpins its relevance.

Regarding the risk frames, management recommendations should focus on aortic rupture, sudden death and susceptibility for infectious diseases especially between 12th to 16th week of age (Hafez 2006), which is in accordance with Beaulac et al. (2019), who confirms the time frame for an increased risk. From 12th to 16th week of age Beaulac et al. (2019) reported an increase in mortality around $4.1 \%$ to $6.7 \%$ in groups with different stocking densities (30 to $60 \mathrm{~kg} / \mathrm{m}^{2}$ ). Most of the birds (38 to 42 $\%$ ) were culled due to suffering injuries caused by aggressive behavior resulting from damage pecking. Second most causes for mortality and culls could be traced back to metabolic diseases. The already high losses due to aggressive behavior becomes even more important in the context of the planned ban of beak trimming in German turkey husbandry. Again, management measures gain importance as addressing this issue is essential for animal welfare and productivity of un-debeaked turkey flocks. The present results indicate that more on-farm measurements are needed per se. This, however, requires a continuous evaluation of losses especially in the first week of life as well as from week 12 ongoing. Further studies are needed in order to explain main reasons for the increased mortality from week 13 and 14 until slaughtering. This would allow to derive countermeasures which is from significant importance not only regarding animal welfare aspects but also to maintain and increase production efficiency (which includes economic and ecological aspects). To identify critical time frames in context with health, environment and behavior the documentation and evaluation of reasons for mortality could help to improve preventive flock management. Available data about health and livability (e.g. mortality rate, medication) of the rearing period would improve the implementation of preventive management measures for the rearing and the grow-out production site and thus 
support improvement of health and vitality not only during rearing but also during the fattening period. The 'Federal voluntary agreement of turkey husbandry' (VDP 2013) requires documentation of the mortality rate during rearing. This documentation and, more important, the transmission of this information to the fattening production site would increase the responsibility for flock health over the whole production process.

\section{Use of the indicator 'foot pad health' as part of on-farm-monitoring in poultry flocks}

An on-farm monitoring requires knowledge about time frames of risk and risk factors for foot pad lesions. To consider the whole husbandry period, in the current study (Chapter 3 and Chapter 5) foot pad monitoring started with housing the chicks and ended up with post mortem evaluation. First lesions were detected in turkey and broiler chicks within the first week of life which is in accordance with findings from Bergmann et al. (2013) and Mayne et al. (2006). In the study of Bergmann et al. (2013) 5,531 birds and 60 birds per flock and per visit were examined which is comparable to the study design in Chapter 3. In both Bergmann et al. (2013) and in the study of this thesis a modified 5-point scoring system was used and Score $0=$ intact foot pad without an abnormality was separated from Score 1 = hyperkeratosis and elongated reticulate scales. The scoring system of Bergmann et al. (2013) was adopted for the present study as current scoring systems like Knierim et al. (2016) do not cover the development and detection of first lesions. In the context of improving welfare this might be an important aspect as we proved in Chapter 4 that almost $40 \%$ of 1,382 foot pairs showed macroscopic alterations and at least one foot was affected after the first week of housing. Mayne et al. (2006) took 40 birds from commercial barns and investigated macroscopic and histological alterations from the first week of life until the 21 st week. After the first week little minor cellular changes with both an unaffected epidermis with no evidence of inflammatory cells and also a ruptured epidermis was proved and after 3 weeks the authors observed fully developed lesions with damage at the epidermis. Therefore, the rearing period was outlined as a risk period for foot pad lesions.

Starting with rather small and keratinized lesions, foot pad damages can subsequently lead to necrosis and ulcerations which were shown to affect the basal membrane and 
sensitive nerve endings (Buda et al. 2002). Spindler (2007) investigated 160 metatarsal pads from 21 week old male turkeys and derived from the studies that the more severe a macroscopic foot pad lesion the higher the risk of an ulceration and thus being painful to the birds and welfare relevant. Furthermore, the study pointed out histological alterations of foot pads which were categorized macroscopically unaffected $(n=13$; epidermal alterations but no ulceration and proof of heterophil granulocytes) (Spindler 2007). The results were the basis for the study in Chapter 4 and damages at the basal membrane were also linked to a footpad which was macroscopically categorized as Score 1.

Concerning the demand for avoidable pain, suffer and damage in poultry housing ( $§ 1$ TierSchG) it is important to prevent FPD by getting knowledge about time frames of risk, reasons and main effects on foot pad lesions and also valid methods of foot pad health evaluation. In Chapter 3 the authors found a markedly increase of FPD between the fourth and eights week of life with a higher score during winter time compared to summer season (April to September). The timespan was equal to Rudolf (2008) who investigated foot pad health in a group of about 6,000 turkeys. The birds were kept on wood shavings (rearing) and long barley straw or wood shavings (grow-out) and the macroscopic FPD monitoring based on a 6-point scoring system. For one side, FPD severity was higher during the winter cycle compared to the summer cycle which is equal to the results in Chapter 3. For another side, birds which were kept on long barley straw had more severe foot pad lesions than turkeys which were housed on wood shavings during the fattening period. It is already proven that negative impacts on foot pad health are directly caused by the environmental conditions which the birds are exposed to. Mayne et al. (2007) kept 96 turkeys on clean dry (87\% dry matter) and clean wet (26\% dry matter) litter from 28 days of age and birds within the wet litter group had macroscopically and histologically severe lesions with a split epidermis after six days compared to mild lesions from birds kept on dry litter. Birds were kept on about seven cm wood shavings. In another experiment Mayne et al. (2007) pointed out that after six days foot pads from turkeys which were kept on long barley straw were most affected (medium-severe lesions with necrosis up to a quarter of the footpads) but keeping turkey on wood shavings led to necrotic and medium severe lesions as well. Differences between litter materials could be explained by quality 
parameters like water binding and releasing capacity. Chopped straw resulted in 9 to $10 \mathrm{~g}$ water binding capacity per $1 \mathrm{~g}$ litter after 4 weeks compared to about $6 \mathrm{~g}$ in samples of wood shavings while less releasing capacity in straw was proved in the study from Youssef et al. (2010). The lower water release from straw could explain the results of Chapter 3 regarding the limited effect of high amounts of chopped straw as a litter material on foot pad health. The results of Chapter 4 indicate a risk-orientated use instead of a fix dispersing interval leads to a reduced straw application over the whole fattening period and thus to a reduced usage of bedding material. Then foot pad health was equal or even better compared to flocks with a higher dispersing interval (11.214.2 versus $17.5-22.6 \mathrm{~kg} \mathrm{straw} / \mathrm{m}^{2}$ ). As litter moisture is the most causative agent of FPD (Wu and Hocking 2011, Youssef et al. 2011, Mayne et al. 2007) water from excreta, drinker lines and ventilation influences the bedding and climate within the barn. Therefore, litter management has to address moisture content of the litter in order to keep the birds' feet healthy and to promote respiratory diseases prevention. Expected situations leading to an increase of litter moisture like vaccination or a change of feedstuff, would require a more intensive bedding-management compared to other time frames of the production period. Rudolf (2008) pointed out a higher risk of FPD in turkey flocks during winter months compared to summer months, and made out week 11 as the highest amount of dispersed litter and thus a risk of wet litter during that time span, independently from season. Albeit harboring a higher risk of developing foot pad alteration, chopped or long straw is still one of the most available and used bedding material during fattening (Berk 2017, Strüve et al. 2017, KrautwaldJunghanns et al. 2011). While litter moisture was proved as the highest risk for FPD, in the study of Chapter 5 the effect of $\mathrm{pH}$-value on foot pad health was investigated. The application of a sodium-bisulfate-complex (SBS) to reduce $\mathrm{pH}$-value of the litter and decrease microbial activity and thus prevent skin irritations via reducing ammonia emissions from excreta was part of the study in Chapter 5. A poultry litter treatment, which is a common litter treatment in the US (Tasistro et al. 2007), was adopted and used in varying amounts. The published studies were mostly conducted with re-used litter but Li et al. (2013) applied 183 or $366 \mathrm{~g} / \mathrm{m}^{2}$ SBS on new dispersed wood shavings in an experimental study with female Ross broilers. In contrast to our study the authors re-applied SBS once a week from 3 weeks ongoing. Litter $\mathrm{pH}$-value was reduced to 
pH 4 to 5 until 35 days of age when applying the highest SBS rate (lower SBS rate led to $\mathrm{pH}$-value slightly above 6 vs. up to $\mathrm{pH} 8$ in control groups). FPD score was 0.67 in both SBS groups compared to 1.33 in control groups (scored in accordance to Welfare Quality $^{\circledR}$ Protocol Score 0 to 4$)$ after 8 weeks. The reduction of uric acid decomposition by reducing microbial activity was exposed to reduce FPD by Li et al. (2013). As shown in Chapter 5, keeping the pH-value below pH 5 up to 14 days after broiler chick placement improved foot pad health until time of slaughtering even if litter moisture content was comparable or higher in the trial group compared to the control group (cf. Table 14). Therefore, beside moisture content $\mathrm{pH}$-value also influenced environmental conditions of the birds and thus would support birds' welfare. Both litter parameters obviously affected foot pad health, whereby Youssef et al. (2011) clearly pointed out the primary effect of water content in litter (27\%) on FPD in a study with female turkeys. The authors exposed the birds on wood shavings with either only added water, or water with $\mathrm{NH}_{4} \mathrm{CL}$ or uric acid for 8 hours. In the latter study the water content of the bedding was determined in accordance to the Darrmethod (VDLUFA 2014). This method is comparable to the study in Chapter 5 but a hygroscopic material was applied to decrease litter $\mathrm{pH}$-value. It was assumed, that SBS lowers $\mathrm{pH}$-value and would decrease $\mathrm{a}_{\mathrm{w}}$-value and thus free water content and water activity $\left(a_{w}\right)$ would be addressed as positive effects and to improve foot pad health (Dunlop et al. 2016). However, water activity of the litter was not measured in the study of this thesis.

Beside the effect on FPD, litter quality plays an important role to enable the birds' normal behavior and thus fulfill $\$ 2$ TierSchG (2017). Behavior like plumage care and dustbathing, foraging and pecking require an enriched environment and dry and friable litter (EU 2002, VDP 2013). Therefore, besides quality parameters the structure of the litter plays an important role in poultry husbandry. The Welfare Quality® (2009) assessment protocol describes a five point scoring for litter assessment $(0=$ dry and flaky to $4=$ wet and sticky under hard crust) but as part of an early risk assessment an automatic monitoring and evaluation of litter parameters could support the improvement of litter quality and could prevent foot pad lesions. Due to foot pad health' linkage to measurable litter quality parameters the automatic assessment could increase the acceptance of the indicator foot pad health by giving additional 
information about the environment and reduce the monitoring dates during the husbandry period.

Derived from the study results turkey and broiler farmers should expect foot pad alterations during the early rearing period and at time of bird placement into the fattening barn. Several factors need to be considered to introduce a risk assessment for foot pad health in the grower facility, to estimate a sample size of FPD monitoring and management efforts during the husbandry period. However, as long as no automated on-farm assessment method for FPD exists, FPD assessment has to be carried out manually which implies manual handling of the birds with the potential negative impacts regarding labor protection (especially in turkeys) and animal health and welfare. Indirect measurements via the 'transact walk' (Marchewka et al. 2015) or the assessment of birds' walking ability (Hocking et al. 2017) could not be established yet. Hocking et al. (2017) investigated turkeys' behavior $(n=66)$ in correlation with FPD severity (none FPD, mild/medium, and severe $=$ Score 4 in accordance to Hocking et al. 2008). Several analgesics were injected to investigate the effect on turkeys' behavior and thus the welfare relevance of FPD on pain in affected birds. No differences were proved between the different FPD severities regarding walking and resting behavior. Krautwald-Junghanns et al. (2011) derived from their field study results that birds which were most affected by FPD did not show conspicuous gait scoring. Nevertheless, Wu and Hocking (2011) investigated the relation between litter quality, foot pad health and turkeys' behavior with a negative effect from wet litter on e.g. foraging, preen standing and time for walking and also a higher prevalence of FPD in wet litter groups. At 70 days of age the birds on wet litter showed significantly more pecking on other birds and less sitting compared to the dry litter group which would be an important welfare aspect. This might support the issue using foot pad health as a feasible indicator for the possibility of exerting normal behavior in an adequate environment and would fulfill the on-farm monitoring to prove e.g. normal activity and an appropriate housing ( $\$ 11,8$ ref. to $\S 2$ TierSchG 2017). It also underlines the importance to ensure friable and clean bedding material at every time of the husbandry period due to the impact of housing conditions on birds' physical integrity and to enable the bird to perform natural behavior like foraging and preening (WBA 2015, Nds. MBI 2014, Knierim 2001). 
The severity of foot pad lesions can be reduced by keeping birds on dry litter. A period of 15 days for healing and scar formation was observed by Mayne et al. (2007). In the study 72 turkeys were kept on wet (26\% DM) litter for 48 hours followed by a period on dry ( $87 \% \mathrm{DM})$ litter of pine wood shavings from 3 weeks of age. The birds metatarsal pad recovered and scars were visible due to an eliminated scale structure and a pale and even foot pad. The turkeys were assessed macroscopically (Score 0 to 7) and FPD severity decreased from 6.7 to 0.9 after 15 days. Also Platt (2004) described evidence of scar tissue at the end of the fattening period in most of the bird's foot pads in her study. The author also stated that week 14 to 21 of life represents a good healing potential window (Platt 2004). Scar formation on a metatarsal pad was macroscopically visible in the study of Chapter 4 (Table 11) as described by Platt (2004). The alterations of the foot were evaluated as Score 1. As part of an on-farm monitoring the information about scar formation could be important for the acceptance of the flock assessment due to the information about successful or failed management measures. A separate category of the assessment scheme for scar formation could support the informative value and hence a contemporary implementation of management measures if required. The investigated metatarsal pads in the study of Chapter 4 with macroscopically proved scar formation showed a moderate ulcer and infiltration of granulocytes in the epidermis and dermis. Histological sections from turkeys' feet which recovered after an exposure on wet litter showed cellular changes and inflammatory cells were proved as well (Mayne et al. 2007). To which extent it is painful to the birds has not been proven clearly yet, e.g. Wyneken et al. (2015) only proved this for severe lesions.

The information of a recovered lesion by an on-farm monitoring and from post mortem evaluation would motivate stockmen and would show the potential of certain management measures. Therefore, a post mortem foot pad assessment scheme should inform about scar formation which requires an extended evaluation system and a suitable camera technique as well.

Furthermore, the most affected foot should be considered when assessing birds' health and welfare to strengthen the adjustment of FPD assessment against the background of a welfare indicator. It has been proven that the correlation coefficient between foot pad alterations on the feet of a respective foot pair is rather variable (between $r=1,000$ 
and $\mathrm{r}=0,550$ for both, males and females) (Chapter 4). The method is in contrast to Krautwald-Junghanns et al. (2011) and Allain et al. (2013) who only assessed the right foot of a bird whereas the present study (the 'worst' foot) is in accordance with Hocking et al. (2017) and Knierim et al. (2016). However, the applied sample sizes in the present study might be a compromise between feasibility and the expected FPD prevalence. Therefore, sample sizes were calculated based on the expected FPD prevalence, however, the applied methodology shows weaknesses if FPD prevalence is below $10 \%$ or above $90 \%$ as it would lead to an improper precision of $5 \%$ (Naing et al. 2006). Nevertheless, as FPD prevalence is an estimated value under field conditions, the applied calculation formula is sufficient.

Overall, the rearing period (until the age of eight weeks) was shown to bear the highest risk to develop foot pad alterations. In contrast to the idea of an indicator based and preventive flock management, collection of data and information as well as assessment and benchmarking are currently performed based on the post mortem inspection at the abattoir (QS 2020, VDP 2013). With the knowledge of those management measures farmers could derive the risk for foot pad alterations within the current flock and transfer information to the fattening production-site as well.

\section{Approaches for an objective foot pad assessment method to improve animal welfare}

To fulfil requirements of an indicator-based system the assessment methodology has to be objective, feasible, valid and reliable (Veissier et al. 2013).

A technical-based evaluation with standardized test criterions and the use of an external standard would strengthen the objective, valid and feasible foot pad assessment. Since the demands of the quality assurance system (QS 2020) include the FPD scoring based on an imaging-system for most of the slaughterhouses, the manual assessment of post mortem FPD evaluation decreased rapidly. After culling of the birds, the feet are clean and the light conditions at the slaughterhouse are standardized compared to on-farm monitoring (De Jong et al. 2012). Vanderhasselt et al. (2013) compared the manual on-farm assessment (two days prior slaughtering) with the automated and manual post mortem evaluation of foot pad health in broiler flocks. Foot pads of 200 broilers were assessed on-farm in accordance to the 5-point scale of 
Welfare Quality ${ }^{\circledR}$ (highest score of a pair was evaluated) and results were clustered into three categories of the so called Swedish System (Ekstrand et al. 1998) which was used at the slaughter house. If all results from the camera system were included onfarm and automated assessment pointed out $\mathrm{r}=0.54$ and $\mathrm{r}=0.59$ between manual p.m. evaluation vs. camera-based system. Correlation increased to $\mathrm{r}=0.68$ and $\mathrm{r}=0.83$ when only technically correct results were considered $(n=83)$. Nevertheless, it was pointed out that especially more severe affected foot pads were not identified by the camera system (monitoring failed) and the manually on-farm assessment under experimental conditions needs to be considered.

Nevertheless, besides technical improvements there are some other aspects which need to be considered during the process to increase validation of FPD assessment.

Lund et al. (2017) proved a lower FPD level and thus lower FPD severity in favor of manual evaluation compared to an automatic system at the slaughterhouse. The authors performed the evaluation referring to a three-point scale. In accordance to Lund et al. (2017) a higher percentage of foot pads in Score 3 (most severe) were detected by an automatic system compared to the manual assessment. Thus, FPD severity was underestimated by human classification or the automated system was not calibrated properly. Van Harn and De Jong (2017) validated a camera system compared to human assessors ( $\mathrm{n}=100$ chicken feet) and the correlation between both methods was very high with $\mathrm{R}^{2}=0.96$. Albeit it was another result of the study that foot pads with visually categorized small lesions were scored worse by the camera. Flocks which were classified worse by observers received a less severe classification by the video imaging system. Misinterpretation due to underestimating highest and lowest classes indicates another disadvantage of manual evaluation, in particular of a three-point scoring. As a result, intermediate scores would be overestimated in determining foot pad alterations. The validation of the imaging system from van Harn and De Jong (2017) was based on a three-point scale and showed higher scorings from the imaging system when flocks suffered low foot pad lesion scores whereas flocks with high foot pad lesion scores were assessed on a lower score level from the camera system compared to manual assessment results. Those investigations highlight a shift between camerabased and manual foot pad assessment methods. In a field study De Jong et al. (2012) investigated the level of inaccuracy of an on-farm FPD assessment dependent on FPD 
prevalence in broiler flocks. Based on a three-point scale the level of inaccuracy was highest in flocks with intermediate FPD levels due to the ordinal scale of foot pad monitoring. Those aspects would support the use of an FP monitoring based on an evaluation system with more score levels in order to reduce the failure of a single foot pad assessment. The wider the range of a scoring system (the more grades) the lower the weighted failure of a single foot pad measurement.

Generally, the effect of subjectivity increases during FPD assessment due to the fact that the boundary of the metatarsal pad is not defined and interpreted in the same way for camera and manual assessment yet. A feasible and precise use of a scoring scheme fails if the size of the determined necrosis refers to the area of the metatarsal pad (Hocking et al. 2008, Knierim et al. 2016). Currently, the camera based automatic system records the altered dark area of the foot pad which is in accordance with the scheme of Hocking et al. (2008). However, as it was shown in table 12, Chapter 4, the boundary of the metatarsal pad consists of a smaller area (smaller external diameter) compared to the FPD software at the slaughter house. The results of the foot pad monitoring might also differ due to missing the 3D-effect with the imageJ system but it points out the discrepancy of the different reference quantity of the metatarsal pad (cf. Figure 8). Therefore, derived from this aspect the manual assessment needs to be clarified and the boundary must include the interpad space as shown in Figure 1. Overall, the outcome of a manual and camera-based foot pad assessment may not be comparable. 

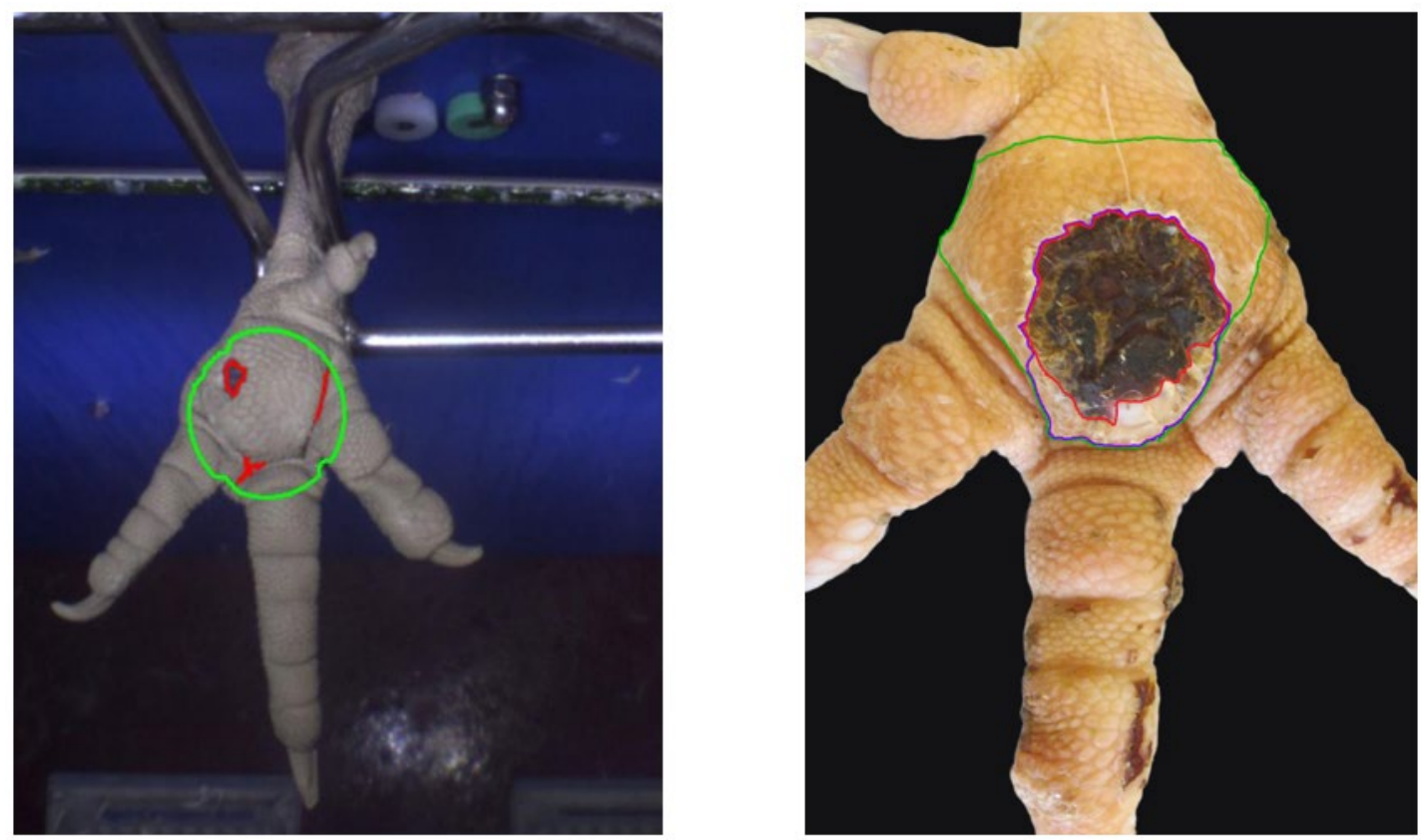

Figure 8: Boundary of the metatarsal pad (green line) by the camera system (left; Dummy of a turkey foot in a slaughterline, tagged by CLK Turkey Check) and manual assessment (right; freehand drawn)

The mismatch between the imaging system and the manual assessment is strengthened by the phenomen of optical illusion. With focus on the assessment of foot pad alterations the Ebbinghaus - Illusion, an optical illusion of relative size perception, influences the result of the human observer (Axelrod et al. 2017). Circles appear smaller or bigger, depending on the relative size of the foot pad in relation to the position of the necrotic area as well as the size and appearance of different necroses. This has a strong effect on the foot pad assessment and is described in Table 12, i.a. referred to the Score 4 of the Hocking system. The picture No.1, which is originally used in the official European assessment scheme, imaged necrotic area more than half of the metatarsal pad' but measured by the visual system (ImageJ) the necrotic area resulted in a size of about one quarter of the metatarsal pad. Additionally, to that mismatch, the size of the metatarsal pad would increase by using a camera-based system and thus reduce the necrotic area to less than $25 \%$ of the basal area and improve the score level. The post mortem evaluation is linked to a sanctioning system and conspicuous flocks are detected by the percentage of foot pads which were classified in score 4 (more than half of the metatarsal pad is necrotic; Toppel and Andersson 2016). 
Several settings for validation purposes are necessary to strengthen a technical system (van Harn and de Jong 2017). Since January 1st 2020 the german quality assurance system (QS) demands a documentation of technical parameters of the camera system. This measure is expected to increase the validity of the assessment method and to strengthen the results of foot pad scorings. A proper assessment method allows an unambiguous assignment of conspicuous flocks to either missing welfare standards on-farm or misclassification due to technical failure at slaughterhouse. An important issue, necessary for the improvement of FPD assessment validity, is the implementation of an external standard that promotes the comparability of foot pad results. A comparison between several slaughterhouses would be possible and prevent displacements in favor of single slaughterhouses. In accordance to Petermann et al. (2017) a so called "Dummy" should be developed and tested within the animal welfare plan of Lower Saxony and will be applied in the near future in order to make results within a slaughterhouse and between different slaughterhouses comparable and replicable (cf. Figure 8 left picture).

A transparent and valid system would increase the acceptance and traceability for farm managers and support the voluntary foot pad assessment as part of on-farm monitoring. Other methods like the assessment of the gait in relation to the grade of foot pad alterations were tested. Wyneken et al. (2015) proved the relation between FPD and gait scoring by using a tactile force and pressure measurement system for the gait scoring and manual FPD assessment according to Mayne et al. (2007). The authors induced FPD alterations by increasing litter moisture. Several parameters like walking speed, standing time but also litter moisture were used to interpret behavior and the relation to status quo of foot pad health but the latter against the background that foot pad lesions are painful which might prevent an early detection of foot pad lesions and thus would not be useful for on-farm monitoring. Aydin et al. (2010) showed on the basis of a fully automatic imaging in broilers that the activity and gait score are not linear correlated and only the highest (worst) scored birds showed reduced activity. Thus, indirect measurements might support on-farm monitoring of FPD to indicate husbandry conditions and welfare standards but an essential factor would be to increase comparability and transparency of foot pad assessment per se and thus, to 
make it an even more useful tool to evaluate and improve animal welfare based on onfarm and post mortem assessment.

\section{Conclusions of the thesis/ Recommendations for an indicator-based}

\section{management:}

The use of animal welfare- related indicators enables relevant persons to assess housing conditions and management practices which are directly related to the state of the bird itself. While assessing the health and welfare conditions on-farm the farmer is able to implement measurements while the flock is still alive and thus, birds will benefit from improved husbandry conditions directly. Promoting indicators which are already established within the poultry production system would probably increase the acceptance of an indicator-based system by the stockman due to time saving interpretation issues. The number of culled and dead birds indicate the prevalence and intensity of certain health problems within a flock which can be associated with pain, harm and discomfort. The early and continuous evaluation of mortality data would support a risk-oriented management and could improve husbandry conditions of the birds and thus birds' health and welfare. Due to the early and continuous detection of foot pad lesions and its strong relation to the quality of the bedding material, foot pad health seems to be a good animal-related indicator for housing, feeding and care conditions.

Within a risk-oriented flock management both indicators require the use of target areas and threshold levels instead of limit values to enable an early detection during the production period and also to act in time if needed. The interpretation of indicators requires the knowledge and use of corridors instead of fixed values to consider variations within the biological system. This would increase the acceptance for an indicator-based on-farm management system and thus increase birds' health and welfare. 


\section{References}

Abramoff, M.D., Magalhães, P.J., Ram, S. J. (2004): Image processing with ImageJ. Biophotonics International. 11:(7)36-42.

Allain, V., Huonnic, D., Rouina, M. and Michel, V. (2013): Prevalence of skin lesions in turkeys at slaughter. Br. Poultry Sci. 54:33-41.

Andersson, R., Toppel, K. and Heesen, S. (2015): Kann man Tierwohl messen? In Damme, K. and Muth, F. (ed.): Geflügeljahrbuch 2016. Ulmer Verlag, Stuttgart, 2432.

Axelrod, V., Schwarzkopf, D.S., Gilaie-Dotan, S. and Rees, G. (2017): Perceptual similarity and the neural correlates of geometrical illusions in human brain structure. Scientific Reports. 7:39968. doi 10.1038/srep39968.

Aydin, A., Cangar, O., Ozcan, S.E., Bahr, C., Berckmans, D. (2010): Application of a fully automatic analysis tool to assess the activity of broilerchickens with different gait scores. Computers and Electronics in Agriculture. 73:194-199.

Beaulac, K., Classen, H.L., Gomis, S., Sakamoto, K.S., Crowe, T.G. and SchweanLardner, K. (2019): The effects of stocking density on turkey tom performance and environment to 16 weeks of age. Poultry Sci. 0:1-12. doi.org/10.3382/ps/pez087.

Bergmann, S., Ziegler, N., Bartels, T., Hübel, J., Schumacher, C., Rauch, E., Brandl, S., Bender, A., Casalicchio, G., Krautwald-Junghanns, M.E. and Erhard, M.H. (2013): Prevalence and severity of foot pad alterations in Germann turkey poults during the early rearing phase. Poultry Sci. 92:1171-1176.

Berk, J. (2017): Faustzahlen zur Haltung von Mastgeflügel. In. Geflügeljahrbuch 2018. (ed. Damme, K. and Muth, F.). Eugen Ulmer Verlag, Stuttgart. 197-218.

Bir, C., Davis, M., Widmar, N., Zuelly, S. and Erasmus, M. (2019): Perceptions of Animal Welfare with a Special Focus on Turkeys. Front. Vet. Sci. 6:413. doi: $10.3389 /$ fvets.2019.00413.

Buda, S., Platt, S. and Budras, K.D. (2002): Sensory nerve endings in the footpads of turkeys. Proceedings of the 4th International Symposium on Turkey Diseases. Berlin. 78-82.

Carver, D.K., Fetrow, I.J., Gerig, T., Krueger, K.K. and Barnes, H.J. (2002): Hatchery and Transportation Factors Associated with Early Poult Mortality in Commercial Turkey Flocks. Poultry Sci. 81:1818-1825.

Collins, T.J. (2018): ImageJ for microscopy. BioTechniques. 43:1. S Imaging Frontiers.

Damme, K. (2018): Poultry Business studies. Faustzahlen der Landwirtschaft. In: In: K. Damme, F. Muth and A. Mayer (ed.): Geflügeljahrbuch 2019. Schwerpunkt Deutschland im internationalen Vergleich. Stuttgart: Eugen Ulmer.

Dawkins, M.S. (2012): Commercial scale research and assessment of poultry welfare. Br. Poult. Sci. 53:1-6. 
De Jong, I.C., van Harn, J., Gunnink, H., Lourens, A. and van Riel, J.W. (2012): Measuring foot-pad lesions in commercial broiler houses. Some aspects of methodology. Animal Welfare. 21:(3)325-330. doi: 10.7120/09627286.21.3.325.

Doube, M., Kłosowski, M., Arganda-Carreras, I., Cordelières, F.P., Dougherty, R.P., Jackson, J.S., Schmid, B., Hutchinson, J.R., Shefelbine, S.J. (2010): BoneJ: Free and extensible bone image analysis in ImageJ. Bone. 47:(6)1076-1079.

Dunlop. M.W., Moss, A.F., Groves, P.J., Wilkinson, S.J., Stuetz, R.M. and Selle, P.H. (2016): The multidimensional causal factors of 'wet litter' in chicken-meat production. Sci. of the total Environm. 562:766-776.

Ekstrand, C., Carpenter, E., Andersson, I. and Algers, B. (1998): Prevalence and control of foot pad dermatitis in broilers in Sweden, Br. Poultry Sci. 39:318-324.

European Union (2002): Recommendation concerning' turkeys (Meleagris gallopavo spp.) https://www.coe.int/t/e/legal_affairs/legal_cooperation/biological_safety_and_use_of_animals/farming/Rec\%20Turkeys.asp.

Download 12.12.2018.

Ferrante, V., Lolli, S., Ferrari, L., Watanabe, T.T.N., Tremolada, C., Marchewka, J. and Estevez, I. (2019): Differences in prevalence of welfare indicators in male and female turkey flocks (Meleagris gallopavo). Poultry Sci. 0:1-7. doi.org/10.3382/ps/pey534.

Gauly, M. (2016): Geflügelhaltung. In: Hoy, S., Gauly, M. and Krieter, J. Nutztierhaltung und -hygiene. UTB Eugen Ulmer, Stuttgart.

Glatz, P. and Rodda, B. (2013): Turkey farming: Welfare and husbandry issues. African J. Agr. Res. 8:6149-6163.

Hafez, H.M. (2006): Genetic selection of turkey and health related problems. Proceedings of 6th International Symposium on Turkey Diseases, Berlin. 5-16.

Heitmann, S., Stracke, J., Petersen, H., Spindler, B. and Kemper, N. (2018): First approach validating a scoring system for foot-pad dermatitis in broiler chickens developed for application in practice. Prev. Vet. Med. 154:63-70. doi: 10.1016/j.prevetmed.2018.03.013.

Hocking, P. M., Harkness, A., Veldkamp, T. and Vinco, L. J. (2017): Do foot pad scores measure turkey welfare? In: Turkeytimes, editor. Proceedings of the 11 th Turkey Science and Production Conference. 2017 March 9-10; Chester, UK. 20-23.

Hocking, P.M., Mayne, R.K., Else, R.W., French, N.A. and Gatcliffe, J. (2008): Standard European footpad dermatitis scoring system for use in turkey processing plants. World's Poultry Sci. J. 64:323-328.

Jeroch, H., Simon, A. and Zentek, J. (2019): Geflügelernährung. Fütterung des Mastgeflügels. UTB Eugen Ulmer, Stuttgart.

Knierim, U., Andersson, R., Keppler, C., Petermann, S., Rauch, E., Spindler, B. and Zapf, R. (2016): Tierschutzindikatoren: Leitfaden für die Praxis - Geflügel. Kuratorium für Technik und Bauwesen in der Landwirtschaft (KTBL). Darmstadt, Germany. 
Knierim, U. (2001): Grundsätzliche ethologische Überlegungen zur Beurteilung der Tiergerechtheit bei Nutztieren. Dtsch Tierärztl Wochenschr 190:261-266.

Krautwald-Junghanns, M.E., Ellerich, R., Mitterer-Istyagin, H., Ludewig, M., Fehlhaber, K., Schuster, E., Berk, J., Petermann, S. and Bartels, T. (2011): Examinations on the prevalence of footpad lesions and breast skin lesions in British United Turkeys Big 6 fattening turkeys in Germany. Part I: prevalence of footpad lesions. Poultry Sci. 90:555-560.

Krautwald-Junghanns, M.-E., Ellerich, R., Böhme, J., Cramer, K., DellaVolpe, A., Mitterer-Istyagin, H., Ludewig, M., Fehlhaber, K., Schuster, E., Berk, J., Aldehoff. D.; Fulhorst, D., Kruse, W., Dressel, A., Noack, U. and Bartels, T. (2009): Erhebung zur Haltung und Gesundheit bei Mastputen in Deutschland. Berl. Münch. Tierärztl. Wochenschr. 122:271-283.

Kulke, K., Habig, C., Kemper, N. and Spindler, B. (2014): Untersuchungen zum Vorkommen von Kannibalismus bei nicht schnabelgekürzten Putenhähnen bei unterschiedlichen Besatzdichten. Abschlussbericht ML Niedersachsen.

Li, H., Lin, C., Collier, S., Brown, W. and White-Hansen, S. (2013): Assessment of frequent litter amendment application on ammonia emission from broiler operations. J. Air Waste Manag. 63:442-452.

Lorz, A. and Metzger, E. (2019): Tierschutzgesetz - Kommentar. 7. Aufl., München: C.H. Beck. § 11 TierSchG, Betriebliche Eigenkontrollen, 281.

Lund, V. P., Nielsen, L. R., Oliveira, A.R.S., Christensen, J. P. (2017). Evaluation of the Danish footpad lesion surveillance in conventional and organic broilers: Misclassification of scoring. Poultry Sci. 96:2018-2028.

Marchewka, J., Estevez, I., Vezzoli, G., Ferrante, V. and Makagon, M.M. (2015): The transect method: a novel approach to on-farm welfare assessment of commercial turkeys. Poultry Sci. 94:7-16.

Martland, M.F. (1985): Ulcerative dermatitis in broiler chickens: The effects of wet litter, Avian Pathol. 14:353-364.

Martrenchar. A.; Boilletot, E.; Huonnic, D.; Pol, F. (2002): Risk factors for foot-pad dermatitis in chicken and turkey broilers in France. Prev. Vet. Med. 52: 213-226.

Mayne, R.K., Else, R.W. and Hocking, P.M. (2007): High litter moisture alone is sufficient to cause footpad dermatitis in growing turkeys. Br. Poultry Sci. 48:(5)538545 .

Mayne, R.K., Hocking, P.M., Else, R.W. (2006): Footpad dermatitis develops at an early age in commercial turkeys. British Poultry Sci. 47:36-42.

ML Niedersachsen (2016): Tierproduktion in Niedersachsen. URL: http://www.ml.niedersachsen.de/portal/live.php?navigation_id=34208\&article_id=12 1552\&_psmand=7, Download 20.3.2018

Naing, L., Winn, T. and Rusli B.N. (2006): Practical Issues in Calculating the Sample Size for Prevalence Studies. Archives of Orofacial Sciences. 1:9-14.

Nds. MBI (2014): Mindestanforderungen an die Haltung von Puten. RdErl. d. ML v. 4. 12. 2014 - 204.1-42500/0-396 - Mit Änderung der Gültigkeit bis 31.12.2021. 
http://www.nds-voris.de/jportal/?quelle=jlink\&query=VVND-785300-ML20141204-01-SF\&psml=bsvorisprod.psml\&max=true. Download vom 10.12.2019.

Petermann, S., Moors, E., Baumgarte, J. and Sürie, C. (2017): Tierschutzplan Niedersachsen-Arbeitsergebnisse Nutzgeflügel. Berl Munch Tierarztl Wochenschr.130:185-196. doi: 10.2376/0005-9366-16053.

Quinton, C.D., Wood, B.J. and Miller, S.P. (2011): Genetic analysis of survival and fitness in turkeys with multiple-trait animal models. Poultry Sci. 90:2479-2486.

QS (2020): Guideline Diagnostic Data in Poultry Slaughtering. Quality Assurance System.

https://www.google.com/url?sa=t\&rct=j\&q=\&esrc=s\&source=web\&cd=3\&cad=rja\& uact $=8 \&$ ved=2ahUKEwiw4N2FhPzoAhUDNOwKHROvAJEQFjACegQIAxAB\&ur $\mathrm{l}=\mathrm{https} \% 3 \mathrm{~A} \% 2 \mathrm{~F} \% 2 \mathrm{Fwww} . \mathrm{q}-$

s.de $\% 2$ Fservices $\% 2 \mathrm{Ffiles} \% 2 \mathrm{Fdownloadcenter} \% 2 \mathrm{~F} 4$ leitfaeden $\% 2 \mathrm{Fschlachtung} z$ zerl egung\%2Flf_befund_g_frei_\%252001012020_en.pdf\&usg=AOvVaw2Wu_PtOm3z RcladmwMI8fx. 1.1.2020

Platt, S. (2004): Die reticulate scales an den Fußballen schwerer Mastputen und deren Beeinflussung durch unterschiedliche Biotindosierungen unter Feldbedingungen. [dissertation]. [Berlin (GE)]: Free University of Berlin.

Rautenschlein, S. and Ryll, M. (2014): Erkrankungen des Nutzgeflügels: Ursachen, Klinik, Pathologie, Diagnosen, Prophylaxe und Bekämpfung. UTB GmbH, Stuttgart.

Roehrig, C. and Torrey, S. (2019): Mortality and Early Feeding Behavior of Female Turkey Poults During the First Week of Life. Front Vet Sci. 6:129. doi: 10.3389/fvets.2019.00129.

Rudolf, M. (2008): Einfluss von Besatzdichte und Einstreumaterial auf die Pododermatitis bei Mastputen. [dissertation]. [Berlin (GE)]: Free University of Berlin.

Tasistro, A.S., Ritz, C.W. and Kissel, D.E. (2007): Ammonia emissions from broiler litter: response to bedding materials and acidifiers. Br. Poultry Sci. 48:399-405.

TierSchG (2017): "Tierschutzgesetz in der Fassung der Bekanntmachung vom 18. Mai 2006 (BGBl. I S. 1206, 1313), das zuletzt durch Artikel 141 des Gesetzes vom 29. März 2017 (BGB1. I S. 626) geändert worden ist". Download 17.01.2018.

TierSchNutztV (2017): "Tierschutz-Nutztierhaltungsverordnung in der Fassung der Bekanntmachung vom 22. August 2006 (BGB1. I S. 2043), die durch Artikel 3 Absatz 2 des Gesetzes vom 30. Juni 2017 (BGBl. I S. 2147) geändert worden ist".

Toppel, K. and Andersson, R. (2016): Tierschutzindikatoren und Gesundheitskontrollprogramm in der Mastputenhaltung. In: IGN (Ed.) Nutztierhaltung im Fokus. Tierschutzindikatoren am Schlachthof. München, 34-37. ISBN: 978-3-9524555-3-1.

Toppel, K., Strüve, H., Recke, G., Kaufmann, F. and Andersson, R. (2016): Influence of 'Legal Frameworks' on turkey husbandry in North-West Germany. Proceedings of 11th "Hafez" International Symposium on Turkey Diseases. Berlin. 27-36.

Schmitz-Dumont, M. and König, H. (2014): Statistik und Kennzahlen. In: Damme, K. and Muth, F. (ed.) Geflügeljahrbuch 2017. Eugen Ulmer KG, Stuttgart. 
Spindler, B. (2007): Pathologisch-anatomische und histologische Untersuchungen an Gelenken und Fußballen bei Puten der Linie B.U.T. Big 6 bei der Haltung mit und ohne Außenklimabereich. [dissertation]. [Hanover (GE)]: University of Veterinary Medicine Hanover.

Strüve, H., Toppel, K., Andersson, R., Kaufmann, F. and Recke, G. (2017): Wandel der nordwestdeutschen Putenhaltungen durch mehr Tierwohl: Ergebnisse einer Expertenbefragung. Journal of Socio-Economics in Agriculture 10:1-12.

Vanderhasselt, R. F., Sprenger, M., Duchateau, L. and Tuyttens, F.A.M. (2013): Automated assessment of footpad dermatitis in broiler chickens at the slaughter-line: Evaluation and correspondence with human expert scores. Poultry Sci. 92:12-18.

Van Harn, J. and de Jong, I.C. (2017): Validation of Meyn Footpad Inspection System. Wageningen Livestock Research, Report 1044B.

VDLUFA (2014): Bestimmung der Trockenmasse. In: VDLUFA (Hg.): Methodenbuch II.2. Die Untersuchung von Sekundärrohstoffdüngern, Kultursubstraten und Bodenhilfsstoffen. 1. Aufl. mit 2. Erg. Darmstadt: VDLUFAVerl. (Handbuch der landwirtschaftlichen Versuchs- und Untersuchungsmethodik, (Methodenbuch) / im Auftr. des Verbandes Deutscher Landwirtschaftlicher Untersuchungs- und Forschungsanstalten hrsg. von Rolf Bassler; Bd. 2,2).

VDP (2013): Bundeseinheitliche Eckwerte für eine freiwillige Vereinbarung zur Haltung von Mastputen. Bundeseinheitliche Eckwerte, 01.10.2013.

Veissier, I., Winckler, C., Velarde, A., Butterworth, A., Dalmau, A. and Keeling, L. J. (2013): Development of welfare measures and protocols for the collection of data on farms or at slaughter. In: H. Blokhuis, M. Miele, I. Veissier and B. Jones (ed.): Improving farm animal welfare. Wageningen: Wageningen Academic Publishers.

WBA (2015): Wissenschaftlicher Beirat Agrarpolitik beim BMEL. Wege zu einer gesellschaftlich akzeptierten Nutztierhaltung. Gutachten. Berlin.

Welfare Quality ${ }^{\circledR}(2009)$ : Welfare Quality ${ }^{\circledR}$ assessment protocol for poultry (broilers, laying hens). Welfare Quality® Consortium, Lelystad, Netherlands.

Wood, B. J. (2009): Calculating economic values for turkeys using a deterministic production model. Can. J. Anim. Sci. 89:201-213.

$\mathrm{Wu}, \mathrm{K}$. and Hocking, P. M. (2011). Turkeys are equally susceptible to foot pad dermatitis from 1 to 10 weeks of age and foot pad scores were minimized when litter moisture was less than 30\%. Poultry Sci. 90:1170-1178.

Wyneken, C.W, Sinclair, A.R.L., Veldkamp, T., Vinco, L.J. and Hocking, P.M. (2015): Foot pad dermatitis and pain assessment in turkey poults using analgesia and objective gait analysis. Br. Poultry Sci. 56(5) doi 10.1080/00071668.2015.1077203.

Yassin, H., Velthuis, A.G.J., Boerjan, M. and Riel, J. (2009): Field study on broilers' first-week mortality. Poultry Sci. 88(4):798-804.

Youssef, I.M.I. (2011): Experimental studies on effects of diet composition and litter quality on development and severity of foot pad dermatitis in growing turkeys. [dissertation]. [Hanover (GE)]: University of Veterinary Medicine Hanover. 
Youssef, I.M.I., Beineke, A., Rohn, K. and Kamphues, J. (2011): Effects of litter quality (moisture, ammonia, uric acid) on development and severity of foot pad dermatitis in growing turkeys. Avian Dis. 55:51-58.

Youssef, I.M.I., Beineke, A. and Kamphues, J. (2010): Experimental Study on effects of Litter Material and its Quality on Foot Pad Dermatitis in Growing Turkeys. Int. J. Poult. Sci. 9 (12): 1125-1135. 


\section{Publications and presentations}

\section{$\underline{\text { Scientific Paper - peer reviewed }}$}

1. Toppel, K., Spindler, B., Kaufmann, F., Gauly, M., Kemper, N., Andersson, R. (2019):

Foot pad health as part of on-farm-monitoring in turkey flocks.

Front. Vet. Sci. doi: 10.3389/fvets.2019.00025.

2. Toppel, K., Kaufmann, F., Schön, H., Gauly, M., Andersson, R. (2018):

Effect of pH-lowering Litter Amendment on Animal-based welfare Indicators and Litter Quality in a European commercial Broiler Husbandry.

Poultry Science 0:1-9. DOI: org/10.3382/ps/pey489.

3. Toppel, K., Kaufmann, F., Schön, H., Gauly, M., Andersson, R. (2017):

Development of mortality and foot pad health in turkey flocks and its implication for welfare assessment. Berl Münch Tierärztl Wochenschr 130 (5/6) 258-265.

DOI 10.2376/0005-9366-16044.

\section{$\underline{\text { Scientific Conferences - Oral Presentations }}$}

1. Effect of a chemical Litter Amendment on Animal-based welfare Indicators and Litter Quality in a European commercial Chicken Husbandry

Toppel, K., Schön, H., Kaufmann, F., Gauly, M., Andersson, R.

15th European Poultry Conference, Dubrovnik, $17^{\text {th }}$ to $21^{\text {st }}$ September 2018

2. Effect of a pH-lowering Litter Amendment on Animal-based welfare Indicators and Litter Quality in a European Turkey Husbandry

Toppel, K., Kaufmann, F., Gauly, M., Andersson, R.

12th "Hafez" International Symposium on Turkey Diseases. Berlin, $31^{\text {th }}$ May to $2^{\text {nd }}$ June 2018

3. Foot pad health and mortality as part of Controlling in commercial Turkey Production. (2016)

Toppel, K., Schön, H., Kaufmann, F., Gauly, M., Andersson, R.

Book of Abstracts of the 67th Annual Meeting of the European Federation of Animal Science, Belfast, $1^{\text {st }}$ September 2016, 22:531.

\section{Influence of „Legal Frameworks“ on Turkey Husbandry in North-West} Germany.

Toppel, K., Strüve, H., Recke, G., Kaufmann, F., Andersson, R.

11th "Hafez" International Symposium on Turkey Diseases. Berlin, 26th-28th May 2016. 
5. Targeted use of Indicators as part of a controlling system in German Turkey Production.

Toppel, K., Willmes, P., Andersson, R.

Proceedings of the 8th "Hafez" International Symposium on Turkey Production, Berlin, 29.05.2015, 30.

\section{$\underline{\text { Publications }}$}

1. Toppel, K., Kaufmann, F., Schön, H., Gauly, M., Andersson, R. (2018): Effects of $\mathrm{pH}$-lowering litter amendment on animal-based welfare indicators and litter quality in a European commercial broiler husbandry. Proceedings of the 15th European Poultry Conference. 17th to 21st September 2018, Dubrovnik, Croatia, 227. ISBN 978-90- 29157- 0- 9.

2. Toppel, K., Kaufmann, F., Gauly, M., Andersson, R. (2018):

Effect of a pH-lowering Litter Amendment on Animal-based welfare Indicators and Litter Quality in a European Turkey Husbandry. Proceedings of 12th "Hafez" International Symposium on Turkey Diseases. Mensch und Buch Verlag, Berlin. 1924. ISBN 978-3-86387-958-7.

3. Toppel, K., Andersson, R. (2016):

Tierschutzindikatoren und Gesundheitskontrollprogramm in der Mastputenhaltung. Animal welfare indicators and health control program in German turkey husbandry. In: IGN (Ed.) Nutztierhaltung im Fokus. Tierschutzindikatoren am Schlachthof. München, 34-37. ISBN: 978-3-9524555-3-1.

4. Toppel, K., Strüve, H., Recke, G., Kaufmann, F., Andersson, R. (2016): Influence of ,Legal Frameworks' on turkey husbandry in North-West Germany. Proceedings of 11th "Hafez" International Symposium on Turkey Diseases. Mensch und Buch Verlag, Berlin, 27-36. ISBN: 9783863877859.

5. Andersson, R., Toppel, K., Heesen, S. (2015):

Kann man Tierwohl messen? Erste Erfahrungen mit Tierschutz-/Tierwohlindikatoren bei Puten.

How to measure animal welfare? First experiences with welfare and health indicators in turkey production.

Geflügeljahrbuch 2016, Verlag Ulmer, Stuttgart, S.24-32.

6. Andersson, R., Toppel, K. (2014):

Putencontrolling.

Controlling as part of flock management in turkeys.

In: Tiergerechtheit bewerten, KTBL (Ed.), Darmstadt, 109-114.

7. Toppel, K., Kaufmann, F., Andersson, R. (2013):

The new backbone of animal protection in turkey production: Health-monitoring or health-controlling?

Proceedings of the 7th International Symposium on Turkey Production, Berlin, 6971. 


\section{Conferences - Oral Presentations}

1. Feuchte Einstreu managen

Management of wet litter

Toppel, K., Andersson, R.

9. Osnabrücker Geflügelsymposium, 15.05.1018

2. Optimierung der Einstreuqualität beim Mastgeflügel.

Improving litter quality in poultry husbandry.

Toppel, K., Schön, H., Gauly M., Andersson, R.

8. Osnabrücker Geflügelsymposium. Osnabrück, 30.05.2017.

3. Controlling: Ein Ansatz zur Förderung des Tierwohls in Putenbeständen. Controlling: An approach to enhance animal welfare in turkey husbandry.

Toppel, K., Schön, H., Kaufmann, F., Gauly, M., Andersson, R.

16. Fortbildungsveranstaltung des Landesamtes für Verbraucherschutz und der Tierärztekammer Sachsen-Anhalt zum Thema ,Diagnostik und Betreuung von

Wirtschafts- und Ziergeflügel““. Stendal, 28.-29.9.2016.

\section{Indikatorbasiertes Controlling bei Puten.}

Indicator-based Controlling in turkey flocks.

Toppel, K., Andersson, R.

Tagung zur Umsetzung des Gesundheitskontrollprogramms im Rahmen der „Bundeseinheitlichen Eckwerte für eine freiwillige Vereinbarung zur Haltung von Mastputen“. Osnabrück, 20.02.2015.

\section{Herdenmanagement mit Gesundheitskontrollprogramm und} Gesundheitsplan.

Management of turkey flocks including health control program and health plan. Toppel, K., Willmes, P., Andersson, R.

6. Osnabrücker Geflügelsymposium, Osnabrück, 12.02.2015. 


\section{Acknowledgements}

This thesis was conducted within the interdisciplinary doctoral program „Animal Welfare in Intensive Livestock Production Systems“. Many thanks for the Research Funding of the Lower Saxony Ministry for Science and Culture (MWK). It was an absolute rewarding experience to be part of an interdisciplinary group of students and getting government founding by a three year Georg-Christoph-Lichtenberg scholarship.

I would like to thank my supervisor Prof. Dr. Dr. Matthias Gauly for his trustful and valuable support during that long-lasting process of work. Thank you very much for always being reachable and your full and quick support.

I would particularly thank my supervisor Prof. Dr. Robby Andersson for that valuable time. Thank you for sharing all your knowledge with me, for your critical comments, your permanent and unlimited willingness to doubt and debate. You were an excellent mentor to me. Thank you!

Prof. Dr. Nicole Kemper, you reviewed and examined my thesis, thank you so much for your professional and constructive input and your constant availability.

Thanks for professional support and contribution and also mental support to Dr. Falko Kaufmann, Dr. Hans Schön and Dr. Birgit Spindler.

Also many thanks to the Ministry of Food, Agriculture, and Consumer Protection in Lower Saxony (ML), resp. "Tierschutzplan Niedersachsen" for financial and also professional support on our studies.

Lots of data were collected on poultry farms. I am grateful for the trust and support that we got from the farmers and also from several companies and associations from the poultry sector. Particularly I want to mention Dr. Ronald Günther, Dr. Hartmut Meyer and Prof. Dr. Sabine Petermann. Thanks for sharing your knowledge! 
Thanks to the present and past colleagues from Team StanGe: Dr. Anke Redantz, José Daniel Kämmerling†, Dr. Falko Kaufmann, Ina Funke, Dr. Lea Klambeck, Dr. Stefanie Döhring and Tammo Weseloh. It was and is a great pleasure to work with you. And I also want to thank my colleagues from PhD-program, esp. Dr. Hanna Strüve, Heidi Arndt and Dr. Sophie Meyer-Hamme for lots of inspiring discussions and the quite varied time besides talks and presentations.

And special thanks to my friends Dr. Anke Liebert and Saskia Kloos, for lots of nonacademic input but needful energy.

And my biggest thanks to my family for all the support you have shown me through this research. My parents, Achim and Elka Büttner, my brother Torsten and his wife Alita, my grandparents and cousins. Eck bedanke meck von Herzen bi miene Großmudder Elsa. Du hast meck immer unterstützet un an meck geglövet. Danke! Sven und Anna: Thank you so much for your support, your patience and all the daily lovely moments. 


\section{Eidesstattliche Erklärung}

1. Hiermit erkläre ich, dass diese Arbeit weder in gleicher noch in ähnlicher Form bereits anderen Prüfungsbehörden vorgelegen hat.

Weiter erkläre ich, dass ich mich an keiner anderen Hochschule um einen Doktorgrad beworben habe.

Göttingen, den

(Unterschrift)

2. Hiermit erkläre ich eidesstattlich, dass diese Dissertation selbständig und ohne unerlaubte Hilfe angefertigt wurde.

Göttingen, den

(Unterschrift) 